\title{
LUÍS CARLOS VALOIS
}

\section{CONFLITO ENTRE RESSOCIALIZAÇÃO E PRINCÍPIO DA LEGALIDADE PENAL}

Faculdade de Direito da Universidade de São Paulo São Paulo - 2012 


\section{LUÍS CARLOS HONÓRIO DE VALOIS COELHO $\mathrm{N}^{\circ}$ USP 7288140}

\section{CONFLITO ENTRE RESSOCIALIZAÇÃO E O PRINCÍPIO DA LEGALIDADE PENAL}

Dissertação de mestrado apresentada ao Departamento de Direito Penal, Medicina Forense e Criminologia da Faculdade de Direito da Universidade de São Paulo, como requisito parcial para obtenção do título de Mestre, sob a orientação do Professor Alvino Augusto de Sá. 


\section{CONFLITO ENTRE RESSOCIALIZAÇÃO E O PRINCÍPIO DA LEGALIDADE PENAL}

\section{Luís Carlos Honório de Valois Coelho $\mathrm{N}^{\circ}$ USP 7288140}

Dissertação de mestrado apresentada ao Departamento de Direito Penal, Medicina Forense e Criminologia da Faculdade de Direito da Universidade de São Paulo, como requisito parcial para obtenção do título de Mestre, sob a orientação do Professor Alvino Augusto de Sá.

Data da defesa

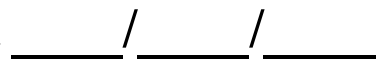

$1^{\circ}$ Examinador

Orientador: Professor Alvino Augusto de Sá

$2^{\circ}$ Examinador

$3^{\circ}$ Examinador 


\section{RESUMO}

O presente trabalho parte da demonstração de não ser o ideal de ressocialização, enraizado na cultura jurídica brasileira, resultado de elaboração científica. Para tanto, recorre aos textos dos precursores, de onde se extrai que a construção desse fim para a pena de prisão se deu com o intuito de humanizar o cárcere, mas sem a comprovação empírica de sua viabilidade. Entretanto, a prática jurisprudencial brasileira coletada demonstra certo descaso para tal evidência. Mesmo diante da violência que permanece imperando na pena de prisão, inúmeros julgados comprovam que os tribunais continuam a usar a ressocialização como fundamento para agravar a pena privativa de liberdade. O Direito perde a sua capacidade de comunicação ao abandonar a realidade como ingrediente. Decisões judiciais, ao usarem termo desacreditado pela história, desistem do diálogo com a sociedade. O princípio da legalidade, com seus pressupostos de clareza e objetividade, fica igualmente prejudicado, com a sanção penal subordinada a uma crença obscura e impossível no meio carcerário. Assim, assumindo que a pena de prisão não se tornará pior com o abandono em definitivo de um ideal desfeito pelo tempo, conclui-se ser o respeito à dignidade da pessoa humana, fundamento do Estado Democrático de Direito, suficiente para o intuito de se continuar buscando uma sanção penal menos desumana.

Palavras-chave: ressocialização - dignidade da pessoa humana - princípio da legalildade execução penal - jurisprudência - diálogo. 


\section{RIASSUNTO}

Il presente lavoro comincia con il dimostrare come l'ideale di risocializzazione, ben radicato nella cultura giuridica brasiliana, non sia il risultato di elaborazione scientifica. Pertanto, si ricorre ai testi dei precursori, dai quali si desume che l'elaborazione di questo scopo di risocializzazione per la reclusione in prigione, derivò dall'intenzione di umanizzare il carcere, ma senza alcuna prova empirica della sua validità. Nel frattempo, la pratica giuridica brasiliana tutta dimostra una certa noncuranza per tale evidenza. Anche davanti alla violenza che continua a regnare nella condanna in carcere, innumerevoli condanne provano che $\mathrm{i}$ tribunali continuino ad usare la risocializzazione come fondamento per aggravare la pena privativa di libertà. Il Diritto perde la sua capacità di comunicazione quando abbandona l'ingrediente della realtà. Le decisioni giudiziali, per usare un termine disprezzato dalla storia, non cercano il dialogo con la società. Il principio di legalità, con i suoi presupposti di chiarezza ed obiettività, prosegue ugualmente pregiudicato dalla sanzione penale subordinata ad una credenzaoscura ed impossibile nel mezzo carcerario. Così, assumendo che la condanna alla prigione non si trasformi in maniera ancora peggio con l'abbandono definitivo di una credenza smentita dal tempo, si conclude che sia il rispetto della dignità dell'essere imano, fondamento dello Stato Democratico di Diritto, sufficiente per l'intuizione di continuare con la ricerca di una sanzione penale meno disumana.

Parole-chiave: roscializzazione - dignità dell'essere imano - principio di legalità esecuzione penale - giurisprudenza - dialogo 


\begin{abstract}
The present work is part of the demonstration of not being the ideal of resocialization, rooted in the Brazilian legal culture, resulted of scientific development. To do so, it turns to the texts of the precursors, from where it extracts that the construction of this order to the imprisonment took place in order to humanize the prison, but with no empirical proof of its viability. However, the Brazilian judicial practice collected shows such disregard to that evidence. Even before violence that still prevails in the imprisonment, many decisions shows that the courts continue to use resocialization as a basis to aggravate the sentence of imprisonment. The law loses its ability to communicate when abandons the reality as an ingredient. Judicial decisions, by using the term discredited by history, give up the dialogue with society. The principle of legality, with its assumptions of clarity and objectivity, is also affected, with the penalty subjected to a obscure and impossible belief in the prison. Thus, assuming the possibility that imprisonment will not become more ruthless with the abandonment of a belief ultimately undone by the time, it appears to be the respect for human dignity, the foundation of the democratic rule of law, sufficient to order to continue to seek a criminal penalty less inhuman.
\end{abstract}

Keywords: resocialization - human dignity - principle of legality - penitentiary law jurisprudence - dialogue 


\section{SUMÁRIO}

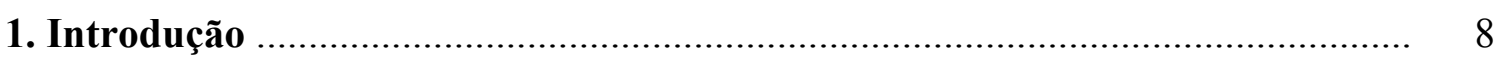

\section{Breve histórico da punição e o sentimento ressocializador}

2.1 A ressocialização na história .................................................................... 18

2.1.1 A pena seletiva entre os antigos .................................................. 18

2.1.2 A prisão como prática ………………………………………... 27

2.1.3 O nascimento da prisão em Foucault .......................................... 32

2.1.4 Primeiros reformadores .......................................................... 37

2.1.4.1 Reformador de prisões: John Howard ........................... 38

2.1.4.2 Reformadores de leis: Beccaria e Bentham ................... 41

2.1.5 Escola positivista .................................................................. 46

2.1.5.1 Antropologia criminal: Cesare Lombroso .................... 47

2.1.5.2 Sociologia criminal: Enrico Ferri ................................ 52

2.1.5.3 Raffaele Garofalo e o crime natural ........................... 56

2.1.6 Os primeiros sistemas penitenciários ........................................... 59

2.1.7 Correcionalismo ………………………………..................... 65

2.1.7.1 Teoria correcionalista ................................................ 66

2.1.7.2 Concepción Arenal ..................................................... 72

2.2 Fins da pena e o ideal de ressocialização .................................................. 77

2.3. O conteúdo da punição ........................................................................... 85

2.4 Funções da ressocialização: mito ou mercadoria ....................................... 90

3. Conflito entre legalidade e ressocialização na jurisprudência.............................. 100

3.1 Legalidade penal e legitimidade punitiva ................................................. 100

3.1.1 Princípio da legalidade da pena .................................................. 100

3.1.2 Direito penal, direito penitenciário e execução penal .................... 106

3.2 A importância da crítica à jurisprudência .................................................. 114

3.3. A individualização judicial da pena e a ressocialização ............................... 122

3.3.1 Individualização e fixação do regime inicial da pena..................... 122

3.3.2 A fixação do regime de cumprimento de pena e o STF ................ 127

3.3.3 A substituição por pena restritiva de direitos ................................. 133 
3.3.4 A dignidade humana como parâmetro .......................................... 135

3.4 Remição pelo trabalho na execução penal .................................................. 139

3.4.1 A natureza do trabalho ............................................................ 139

3.4.2 Trabalho, remição e remuneração ............................................... 143

3.4.3 Remição: direito ou ficção? .................................................... 150

3.4.4 Últimas considerações sobre a remição ......................................... 159

3.5 Pena privativa de liberdade e progressividade …………………………... 162

3.5.1 Progressão de regime e defesa social .......................................... 162

3.5.2 O regime integralmente fechado e o STF .................................... 169

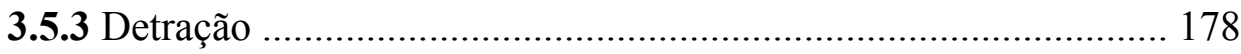

3.5.4 Progressão por salto ................................................................. 180

3.5.5 Livramento condicional ........................................................... 188

3.6 Exame criminológico ou positivismo (defensismo social) criminológico... 191

3.6.1 CTC e o trabalho interdisciplinar ................................................... 191

3.6.2 Positivismo e subjetivação a cargo da medicina ............................ 197

3.6.3 O exame criminológico e a jurisprudência ................................... 210

3.6.4 Requisito subjetivo e princípio da legalidade penal ..................... 224

3.6.5 O poder geral de cautela na execução penal .................................. 228

3.6.6 Últimas considerações sobre o exame criminológico ................... 233

4. A dignidade da pessoa humana como paradigma …………………………... 237

4.1 Ressocialização versus legalidade e dignidade da pessoa humana ............ 237

4.2 A reintegração social: uma proposta .......................................................... 242

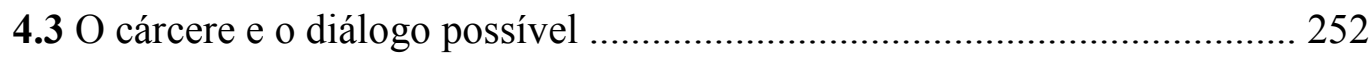

4.3.1 O pessoal penitenciário …………................................................ 252

4.3.2 A participação da comunidade e a experiência do GDUCC ....... 264

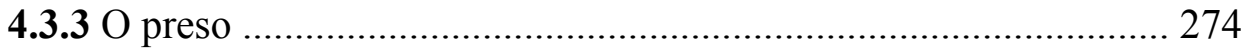

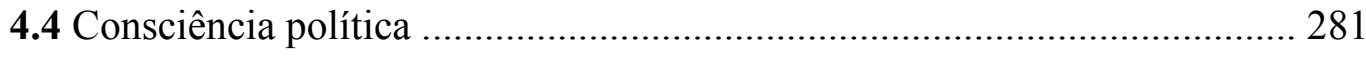

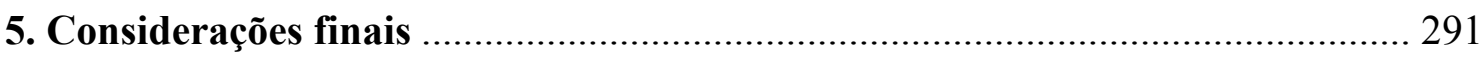

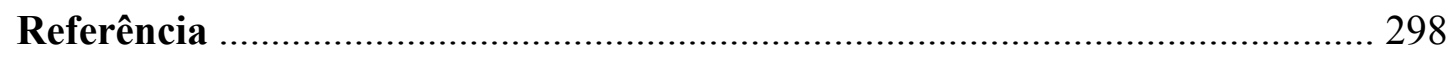




\section{Conflito entre ressocialização e princípio da legalidade penal}

\section{INTRODUÇÃO}

O correto em uma introdução a um trabalho científico, principalmente de natureza jurídica, é que o autor apresente seus objetivos e sua metodologia, sem ser comum a confissão referente aos sentimentos motivadores da escolha de tal ou qual assunto como tema. Todavia, qualquer atividade humana, seja ela a legislativa, a jurisdicional ou a acadêmica, é precedida de interesses que fogem à pura e simples racionalidade.

Em verdade, o próprio conhecimento e a evolução da humanidade estão muitas vezes à mercê de uma lógica afetiva incapaz de ser traduzida em esquemas e que pode ser considerada elemento de retrocesso ou força propulsora de avanço.

Por isso que antes de indicar o caminho a ser traçado até a conclusão deste texto é bom assumir o verdadeiro motor da empreitada: um descrédito total para com qualquer fundamento para a pena privativa de liberdade. A verdadeira função da prisão está estampada na própria visão do cárcere, segregador, constituído por celas lotadas e esquecidas.

Aliás, inclusive as próprias construções dogmáticas das finalidades da pena, são originadas "de acordo com a perspectiva de quem olha e dos olhos de quem olha" (REALE JR, 2006, p. 43), embora não raramente este seja um aspecto abandonado em favor de um caráter científico falsamente imparcial.

Assumindo a incredulidade no que diz respeito às funções da pena privativa de liberdade e a percepção que se tem do cárcere, é necessário explicar o porquê do empenho em um trabalho que tem a execução penal como principal foco, pois a postura que se imagina natural é a do desânimo ou a do ceticismo. Mas é justamente a descrença ou a revolta cega contra a pena de prisão que tornam esse ramo do direito um dos menos estudados, agravando a situação de milhares de pessoas que efetivamente são submetidas ao abandono dos cárceres. Em suma: não acreditamos na prisão, mas há pessoas presas. 
Várias obras criticam a prisão, enquanto o número de trabalhos sobre direito penitenciário é cada vez mais escasso, como se o cárcere estivesse sendo abolido aos poucos, embora esteja acontecendo justamente o contrário. E a manutenção da prisão como pena principal do ordenamento jurídico, por não se sustentar com argumentos racionais, tem criado espaço para a manutenção de princípios totalmente ultrapassados.

Assim, este trabalho tem um objetivo modesto que é o de contestar o uso do ideal ou somente da palavra ressocialização como instrumento legitimador da pena privativa de liberdade. Ou, o que é mais grave, denunciar o uso cínico do termo ressocialização nas decisões judiciais que, desprezando a realidade como componente da hermenêutica, fazem de uma palavra mecanismo puramente encarcerador.

A simplicidade do tema contrasta com a dificuldade em se defender e implementar o reconhecimento do ser humano, quando objeto do direito penal, como sujeito de direitos, dificuldade esta que demonstra a importância de se denunciar a existência de motivações psicológicas dissimuladas em discursos jurídicos cada vez mais ultrapassados.

Na sociedade pós-moderna ${ }^{1}$, as ciências, o sistema jurídico, o político, perdem dia a dia credibilidade, na medida em que, inconscientemente ou não, se mantêm presos às suas antigas racionalidades (BECK, 2003), o que faz com que o sistema punitivo, que sempre sofreu suas deficiências, perca de uma vez por todas qualquer legitimidade, revelando uma ciência jurídica na forma de um descarado exercício de poder.

Na defesa de uma ampla aplicação do princípio da legalidade, necessária será uma (des)construção da história do pensamento ressocializador como um dos fins da pena privativa de liberdade. A busca na história do que pode ser considerado o germe do ideal ressocializador é importante, e assim se iniciará o segundo capítulo. Desconstituindo a real razão de uma teoria pode ficar mais fácil demonstrar a sua inutilidade. Se a aspiração por uma pena

\footnotetext{
${ }^{1}$ A pós-modernidade sinaliza para uma mudança de paradigmas científicos que só podem ser alcançados com certa humildade, postura impensável na modernidade ciosa de sua razão intocável: "Muito menos do que se prendendo a datas e a referências estanques, e aceitando mesmo os riscos inerentes ao uso e emprego da expressão pós-modernidade, entende-se interessante a identificação deste processo de ruptura como modo de se diferenciar e de se designar com clareza o período de transição irrompido no final do século XX, que tem como traço principal a superação dos paradigmas erigidos ao longo da modernidade. A pós-modernidade tem, pois, a ver com a crise da modernidade e com a necessidade de revisão da modernidade". (BITTAR, 2009, p. 105-106).
} 
ressocializadora nasceu de um sentimento natural do ser humano e não de propostas verdadeiramente científicas, insta investigar tal assertiva.

A fascinante história da evolução do sistema penal já foi usada como procedimento para desfazer a ideia de fim da pena. Em 1882, a teoria evolucionista de Lizt adotava esse método para concluir que "a pena necessária é a única pena justa” (2005, p. 52), mas, como o próprio autor reconhece, o estudo histórico da pena, como fenômeno individual e social, não pode cessar.

Ainda no segundo capítulo abordaremos a Escola da Nova Defesa Social, a qual acaba se constituindo em um movimento que vem reforçar e fortalecer o ideal de ressocialização. Sendo escola que visava também humanizar o Direito Penal, resta saber se a sua defesa da ressocialização não era mais um subterfúgio para obter a tão almejada humanização.

Posteriormente, no terceiro item do segundo capítulo, uma reflexão sobre a punição destituída do ideal ressocializador, enquanto o quarto item examina a dificuldade de se livrar desse ideal, em uma abordagem que visa ressaltar como a alienação social tem conseguido manter e reforçar um argumento frágil e destituído de nexo com a realidade. Ambos, terceiro e quarto itens, têm uma exposição em forma de ensaio, sem uma metodologia específica, até porque o que se defende é justamente que punição e ressocialização não são assuntos objetiváveis e passíveis de permanecer como bases científicas de um Estado Democrático de Direito.

Não sendo a ressocialização resultado de conclusões cientificamente comprovadas, passa-se, no terceiro capítulo, a examinar o valor do princípio da legalidade e a difícil tarefa de sua efetivação, principalmente no campo da execução penal, onde os ideais iluministas de clareza e objetividade da lei penal tiveram muito menos espaço.

Deveria ser consequência do Estado de Direito que o princípio da legalidade fosse amplamente aplicado, notadamente como garantia de um dos direitos mais sagrados do ser humano: a liberdade. Não obstante, e no que se refere à execução penal em especial, em detrimento a expressa disposição de lei (Art. $3^{\circ}$. Ao condenado e ao internado serão assegurados todos os direitos não atingidos pela sentença ou pela lei), muitas decisões nessa 
área ainda recebem uma carga enorme de critérios subjetivos, a maior parte deles fundamentados no ideal da ressocialização.

Como nos capítulos seguintes há análise direta de decisões judiciais que usam o argumento ressocializador como instrumento de maior encarceramento, como fundamento para o agravamento da pena ou como obstáculo para a liberdade do cidadão preso, procura-se previamente avaliar a importância do estudo crítico da jurisprudência.

Por mais que tenham sido poucos os avanços que a criminologia obteve e efetivamente transferiu para a prática penal e penitenciária, principalmente quando comparados às verdadeiras intenções dos precursores, o importante é, sem abandonar tais progressos, seguir em frente em uma tentativa de mudança de paradigma, ajudando a pôr fim à estagnação em que se encontra a dogmática jurídico-penal (CAMARGO, 2002-b).

Ainda que a humanização da pena privativa de liberdade tenha sido o objetivo daqueles que fundaram o projeto ressocializador, importa abandonar este argumento, completamente destruído pelos fatos, para verificar o quanto ele cumpriu de sua finalidade e o quanto ele ainda é obstáculo para um maior avanço da ciência penitenciária ou mesmo do tratamento digno da pessoa presa.

Com efeito, se o recolhimento de uma pessoa em uma cela, seu isolamento da sociedade, agravado pelo abandono do Estado, não é meio coerente para favorecer um futuro convívio social, o uso pela jurisprudência do argumento ressocializador é mais grave e não deve ser sustentado em hipótese nenhuma.

Foi admitindo a crise da pós-modernidade e seu efeito na credibilidade das ciências que a opção deste trabalho se limitou à crítica de um argumento e à defesa de um princípio básico, pois chegamos a um momento em que a crítica genérica perdeu efeito e acaba paradoxalmente restringindo a sua capacidade de mudança. Para escapar da irracionalidade do sistema e sair do fosso e da inércia em que nos encontramos passa a ser imprescindível apontar, por mais minuciosa e demorada que tal tarefa possa parecer, cada específica irracionalidade que compõe o sistema. 
Impressionante perceber a força que a palavra ressocialização exerce sobre os ânimos de todos aqueles que por um motivo ou outro abordam a questão da pena. Mesmo quando essa palavra vem compondo um discurso totalmente vazio, como item em um manual para concurso jurídico ou em uma notícia de jornal, ela é forte e seus efeitos devem ser avaliados e combatidos.

Uma única palavra pode resumir a função mestra da prática filosófica: traçar uma linha demarcatória entre ideias verdadeiras e as falsas. A palavra de Lênin... "Toda a luta de classes pode por vezes se resumir à luta por uma palavra contra outra palavra. Algumas palavras lutam entre si, outras são o lugar de um equívoco, contexto de uma batalha decisiva mas indecisa..." (ALTHUSSER apud GUATTARI, 2004, p. 200)

O fato de um termo, que nasceu como fim da sanção penal, ter se transformado em crença dissociada da realidade precisa ser denunciado, porque uma ciência não pode ser feita de abstrações.

Portanto, a partir do terceiro, até o sexto subitem do terceiro capítulo, procurar-se-á identificar na jurisprudência penal e em alguns procedimentos de execução penal, as subjetividades inerentes ao discurso ressocializador e que são obstáculo para o irrestrito emprego do princípio da legalidade.

Quando uma decisão judicial agrava ou aumenta o tempo da pena privativa de liberdade de um cidadão com o argumento de que é medida tomada em prol da ressocialização dessa pessoa, o judiciário não demonstra somente sua face alienada, mas pratica um ato de violência, um ato cego e arbitrário, por ser imposto apesar da absoluta incompreensibilidade.

O uso da força, embora pudesse parecer favorável ao controle e à disciplina, por ser hipócrita, só faz aumentar a tensão social. No sistema penal, qualquer iniciativa direcionada ao controle da criminalidade passa a ter efeito contrário, quando o sistema vem acompanhado de um enunciado ou conjunto de arrazoados completamente desvairados. Nas palavras de Foucault, "quanto mais despótico for o poder, mais numerosos serão os criminosos. O poder forte de um tirano não faz desaparecer os malfeitores; ao contrário, ele os multiplica" (2001, p. 116).

Na prática penal, institutos como a individualização da pena, a remição e a progressão de regime, não têm sido aplicados como direitos dos cidadãos, mas sim sob argumentos débeis que levam em consideração a pena como instrumento ressocializador, fazendo com que 
inúmeros presos fiquem sujeitos ao capricho do juiz, do psicólogo ou do agente de segurança da ocasião.

O hábito do encarceramento tem tornado insensível quem atua diretamente com a prisão e a jurisprudência coletada neste trabalho demonstra bem o quanto o próprio judiciário não se importa com a fundamentação de seus veredictos quando estes favorecem a prática cotidiana do aprisionamento. Realizando justiça ou injustiça, a prática judiciária é linguagem e comunicação (BENJAMIN, 1992), tendo chegado a hora de a dogmática jurídica reconhecer as consequências (des)humanas de suas elaborações, afastando totalmente conteúdos acientíficos.

Neste ponto o trabalho é pretensioso. A abordagem dogmática não se limita a argumentos jurídicos, já tão fracos em seu isolamento, mas busca abranger questões afeitas a outras ciências, tentando fazer uma análise o mais interdisciplinar possível.

Arrisca-se afirmar que o distanciamento entre a dogmática jurídico-penal e outros ramos das ciências humanas, de maneira especial os que compõem a criminologia, é uma das causas da atual pobreza dogmática. Fato que não se pode atribuir somente ao hermetismo da ciência jurídica stricto sensu, mas também a certo afastamento preconceituoso dos demais envolvidos com o estudo do cárcere e das questões sociais relacionadas ao crime.

A pesquisa jurisprudencial é exemplificativa, sem a pretensão de demonstrar posicionamentos majoritários ou minoritários, apesar do grande número de acórdãos encontrados sobre cada tema. Basta uma decisão irracional para que se verifique a inconsistência do sistema, o ruído interpretativo e a consequente fraqueza científica do direito. Quanto à doutrina, não houve predileção por qualquer corrente, sobretudo porque em se tratando de direitos do preso ainda há um "vazio jurídico, uma esfera de irrelevância jurídica" (LOPES, 1994, p 142).

A descrença total para com a prisão e seus pseudo-objetivos não pode levar ao abandono dos que estão efetivamente encarcerados, porque a prática do aprisionamento continua. Assim, longe de querer legitimar o encarceramento, o que se pretende é defender um mínimo de racionalidade à prática judiciária, considerando que esta só pode vir de uma base 
de respeito incondicional ao princípio da legalidade e de abandono do subjetivismo incompatível com o Estado Democrático de Direito.

Se a ciência penal tradicional e a política criminal oficial parecem confusas, "de tal forma que dão a impressão de girar sobre si mesmas em uma extenuante tarefa detalhista dedicada a revisar a teoria e em um indecisa marcha sobre seus próprios passos, orientados à comprovar a política e a ideologia",2 (BARATTA, 2006, p. 7), o que fica claro é que o sistema político como um todo tem demonstrado desgaste e procura se apoiar em pura repressão.

A atividade legislativa, por seu turno, sem qualquer base de cientificismo, atinge imediatamente uma grande população quando se trata da regulamentação da execução penal, sendo necessário que se tire desse emaranhado de regras desconexas um mínimo de coerência, mesmo reconhecendo a sempre atual advertência de ZAFFARONI:

A quebra de racionalidade do discurso jurídico-penal arrasta consigo - como sombra inseparável - a pretendida legitimidade do exercício de poder dos órgãos de nossos sistemas penais. Atualmente, é incontestável que a racionalidade do discurso jurídico-penal tradicional e a consequente legitimidade do sistema penal tornaram-se 'utópicas' e 'atemporais': não se realizarão em lugar algum e em tempo algum (1999, p. 19).

O mestre argentino acusa a imobilidade, inclusive dos críticos do sistema penal quando presos nas regras e princípios desse sistema sem racionalidade, mas reconhece que isso ocorre "na necessidade de defesa concreta e cotidiana dos direitos humanos na operacionalidade desses órgãos" (p. 29).

Este estudo é nesse sentido, para que o princípio da legalidade seja definitivamente respeitado na execução da pena, servindo de parâmetro de interpretação de todos os procedimentos, não dando espaço às suposições e achismos tão comuns nessa área, mas atuando como um verdadeiro garantidor da liberdade.

O quarto capítulo trata da hipótese paradoxal de, com o aumento da legitimidade do sistema, haver a possibilidade de se estar facilitando o diálogo com o encarcerado, favorecendo o "trabalho, não de ressocialização, mas de integração social, conforme entendimento e proposta do grande criminólogo crítico Alessandro Baratta” (SÁ, 2004, p. 21).

\footnotetext{
${ }^{2}$ No original: "en forma tal que dan la impresión de girar ya sobre sí mismas en una extenuante tarea detallista dedicada a revisar la teoría y en una indecisa marcha sobre sus propios pasos, orientados a comprobar la política y la ideologia" (BARATTA, 2006, p. 7)
} 
Aqui mais uma vez a crítica ao cárcere tentará ser posta em segundo plano em benefício do ser humano que de fato está encarcerado e para o qual a crítica não trará benefícios imediatos.

É aparente o antagonismo ou a dissociação entre o capítulo de crítica à jurisprudência e o quarto capítulo, que examina a possibilidade de integração social, pois, como referido acima, o Direito, arbitrário ou não, também deve ser visto como comunicação e, portanto, partícipe inafastável de qualquer processo de diálogo. Para Dotti, “o Direito penal como o direito positivo em geral constituem a estrutura dialogal de sistemas sociais e, por via de consequência, a pena deve ser concebida com um processo de diálogo". (DOTTI, 1999, p. 67).

E não havendo maior obstáculo à comunicação do que a mentira, o encarcerado não vê o sistema jurídico como se este estivesse realmente tentando comunicar algo. Muito pelo contrário, a sensação de repressão surda e muda, ou seja, de violência, é cada vez maior.

Para falar de um provável diálogo com o encarcerado, recorreremos algumas vezes aos ensinamentos de Concepción Arenal, porque se algum autor conseguiu explicar melhor do que ela as dificuldades presentes na comunicação com alguém massacrado por paredes e grades, com certeza ninguém a antecedeu com tamanha clareza, sendo sua obra, escrita em meados do século XIX, sem tradução ou publicação no Brasil, "escandalosamente actual” (CARMENA, 2000, p. I).

A psicologia e a comunicação social ajudam, mas nenhum experto em ciências humanas é capaz de revelar os verdadeiros ruídos e barreiras existentes em uma prisão se não conhece de perto o cárcere, e mais de um século e meio se passou sem que tal tema tenha sido suficientemente abordado.

Não obstante, é crescente a quantidade de órgãos governamentais, de direitos humanos ou religiosos, que frequentam a prisão. Uns podem deixar alguma esperança e outros até levar o resto que ainda houver no cárcere, contudo dificilmente o visitante percebe a força da repercussão - o eco mesmo - de sua conduta naquele lugar, e é sobre isso que se fala no quarto capítulo. 
A complexidade do ser humano venceu todas as tentativas de compartimentação científica, por isso o objetivo é alertar justamente para essa peculiaridade, a de que nem o ambiente hostil da cadeia consegue singularizar o sofrimento. E a licença tomada para falar de assunto que não equivale à tradicional certeza científica, vem da necessidade de se reconhecer que é chegada a hora de diminuir a arrogância do pensamento ocidental, que desde a Grécia antiga se considera "o único lógico" (FERNÁNDEZ-ARNESTO, 2000, p. 118) e o passar dos anos consolidou uma dificuldade tremenda de reflexão.

Os envolvidos com a prática carcerária, guardas, administradores, juízes, promotores, trabalhadores ou somente visitantes voluntários, com maior ou menor grau de humanidade nas suas ações, normalmente se consideram distintos e distantes dos presos, e "estão quase irresistivelmente levados a reproduzir esta divisão social em seu próprio nível, em suas próprias práticas, independentemente da distância que possam estar da vida carcerária em sentido estrito" (COMBESSIE, 2004, p. 144), postura que só faz aumentar o abismo entre preso e comunidade.

Falar sobre esse diálogo não pode trazer nenhum fôlego para essa decrépita forma de punir, ao revés servirá como denúncia do abandono físico e moral dos presos, ao mesmo tempo em que abre a oportunidade para se falar da própria sociedade, já atônita quando se refere aos seus próprios dilemas e sempre indiferente para com os encarcerados.

Inclusive a ideia de comunidade participativa e solidária parece conceito utópico, conquanto o legislador tenha previsto a sua participação na execução da pena (Art. $4^{\circ}$ da LEP), quando "o poder econômico passa a poder social e revela-se como encarnação do princípio unificador do todo" (ADORNO, 2001, p. 176) e até a solidariedade precisa vir fundamentada em alguma razão utilitarista, tornando difícil e complexo falar de diálogo, que é conhecimento recíproco de valores, em uma circunstância dessas.

O presente trabalho, então, tem como ponto de partida três temas que pretendem formar um conjunto dialético. Primeiramente $\left(2^{\circ}\right.$ Capítulo) questionando até que ponto o ideal ressocializador é oriundo de um sentimentalismo carente de qualquer cientificismo, abordando as dificuldades de se desfazer desse equívoco, para em seguida ( $3^{\circ}$ Capítulo) perquirir se a desconstrução dessa base traz maiores garantias ao cidadão preso, em uma crítica à 
jurisprudência encarceradora. E, por último ( $4^{\circ}$ Capítulo), a avaliação é sobre a hipótese de, adotando-se uma prática judicial minimamente verdadeira, estar-se promovendo o início de um diálogo que pode levar mesmo à reflexão da própria sociedade sobre sua prática punitiva.

Utilizar na crítica a necessidade do abandono do ideal ressocializador não é nenhuma novidade e já foi ao que incitou Zygmunt Bauman:

"Muitos criminologistas provavelmente continuarão ainda por algum tempo
revolvendo as querelas tradicionais e jamais resolvidas da ideologia penal - mas de
longe a diferença mais importante é precisamente o abandono de autênticas ou
ambíguas "declarações de intenção reabilitadora" no pensamento contemporâneo dos
que praticam o sistema penal. (1999, p.106).

Nesse sentido está cada um dos capítulos que se seguem, cabendo a advertência de que qualquer trabalho que se presume científico nos dias de hoje deve ter uma certa, se não grande, dose de humildade, sob pena de se produzir mais um texto com ares arbitrários e sem utilidade, admitindo-se de antemão, por isso, que a intenção não é transmitir conclusões absolutas.

A prática prévia do autor na execução da pena, que é a origem do sentimento exposto no início a respeito das funções da prisão, pode auxiliar em algumas ponderações ao mesmo tempo em que é capaz de prejudicar o exame acadêmico de certos temas, por que é difícil manter a isenção quando já se vem acompanhando inúmeras injustiças e se lida constantemente com diversas agressões e mortes financiadas pelo sistema.

Contudo, ainda que fracassados todos os argumentos deste trabalho, se o que houver de emoção conseguir ser percebido por alguém, pelo comprometimento assumido com a verdade e com os princípios que nortearam a elaboração do texto, não terá sido em vão o esforço. 


\section{BREVE HISTÓRICO DA PUNIÇÃO E O SENTIMENTO RESSOCIALIZADOR}

\subsection{A RESSOCIALIZAÇÃO NA HISTÓRIA}

Falar da história da punição sempre será importante, principalmente como introdução a qualquer trabalho que trate de tema relacionado ao direito penal, porque traz logo no início a ideia de que a pena que temos hoje é resultado de um processo cultural e não um item dogmático que pode ser traçado em esquemas precisos e imutáveis.

Neste trabalho, especificamente, a importância se redobra, na medida em que se busca a superação de uma mentalidade estagnada na prática judicial como se fosse um método científico de caráter imutável. E mais, é salutar que o próprio direito se aceite como derivado de uma evolução histórica, a fim de abandonar a altivez de ciência exata que só encobre suas falhas na realização do que mais importa: a Justiça.

O que existe de ressocializador na punição e de punição na ressocialização, não há como esclarecer com exatidão. Nem o melhor historiador seria capaz. Contudo, o breve histórico que se segue aspira somente a isso, demonstrar, mesmo de forma panorâmica, quanto será sempre em vão a atividade de compartimentar o que há no homem de razão e sentimentos, pois o que seja ressocialização hoje, talvez sempre tenha existido.

\subsubsection{A pena seletiva entre os antigos}

Levando-se em consideração toda a história da humanidade, desde que o Estado tomou para si o direito de punir, na maior parte desse período sempre pôde o juiz determinar a morte do culpado. Como o poder do soberano era derivado de Deus, a violação das regras estipuladas era considerada um desrespeito à própria autoridade divina.

Não é de se estranhar, portanto, a dificuldade de se encontrar em sentenças da antiguidade, mesmo as oriundas de localidades que davam maior valor à formalidade do julgamento, expressões que justificassem a punição. 
Ao avaliarmos hoje a aplicação da pena de morte não nos vem outro sentido que não seja o da retribuição e o da dissuasão. Contudo, uma reflexão pode ser feita, se o rei ou o juiz da ocasião podia na maior parte das vezes aplicar a pena capital como punição, quando esta não era aplicada, quando se estipulavam multas, trabalhos forçados ou qualquer outra pena que permitisse ao acusado permanecer vivo, o sentido dessa pena só poderia ser o da correção.

A conclusão segue nesse sentido, pois o rigor comum da justiça não permitiria que o acusado permanecesse na condição de livre entre os demais após uma condenação. Em resumo: o juiz não aplicaria uma pena diferente da capital, se não acreditasse na reforma daquele condenado, por intermédio ou apesar da pena aplicada.

Certo que cedo se percebeu o valor da proporcionalidade, mas como ingrediente de estabilidade do poder $^{3}$, evitando-se a vingança de sangue, onde uma tribo poderia chegar à destruição total de outra em nome da vindita (DOTTI, 2001). A partir da ingerência do rei não se pode mais falar de desproporcionalidade, uma vez que para a violação de regras emanadas diretamente do emissário de Deus a punição com a morte não podia ser desproporcional.

É equivocado pensar, então, que a proporcionalidade nasceu como limite à atividade punitiva do Estado. Ela nasceu no mesmo momento do jus puniendi estatal, como instrumento de controle social e, como dito, de estabilidade do poder. De fato, no decorrer da história, o que menos percebemos é uma verdadeira proporcionalidade na aplicação do direito. Muitas vezes a proporcionalidade resumia-se às formas mais ou menos tormentosas de morrer, regulando suplícios, limitando somente o nível de horror provocado pelo Estado.

O Estado veio substituir a sociedade na prática da violência. Como bem ressaltou Freud, direito e violência apenas nos parecem antíteses, contudo o primeiro tem como fonte a segunda:

a violência podia ser derrotada pela união, e o poder daqueles que se uniam representava, agora, a lei, em contraposição do indivíduo só. Vemos, assim, que lei é a força de uma comunidade. Ainda é violência, pronta para se voltar contra qualquer

\footnotetext{
${ }^{3}$ Já o Código de Hamurabi, termina com a fórmula: "As justas leis que Hamurabi, o sábio rei, estabeleceu e com as quais deu base estável ao governo" (ALTAVILA, 1989, p. 57). Anterior ao Código de Hamurabi, que provavelmente é derivado do período compreendido entre 1726-1686 a.C., há o Código de Ur-Nammu, cerca de 2040 a.C., também da região da Mesopotâmia, que tinha disposição semelhante: "Nesse dia Ur-Nammu, varão forte, rei de Ur, da Suméria e Acádia, com a força de Nanna, rei da cidade (...) a equidade no país estabeleceu, a desordem e iniqüidade (pela força?) cortou (GILISSEN, 1995, p. 64).
} 
indivíduo que se lhe oponha; funciona pelos mesmos métodos e persegue os mesmos objetivos. A única diferença real reside no fato de que aquilo que prevalece não é mais a violência de um indivíduo, mas a violência da comunidade (1977, p. 247).

Quando a pena não era a de morte, independentemente de qual fosse a sanção que a imaginação fértil dos juízes permitisse, ou quando a pena capital era comutada, a sanção verdadeiramente executada era imposta como um verdadeiro benefício, praticamente como se fosse uma absolvição ${ }^{4}$. Isso quando a pena aplicada não era pior do que a morte, no caso das diversas amputações.

Entre os povos da antiguidade, aparentemente os que deixaram maiores informações sobre a prática punitiva foram os romanos, ocasião em que se começa a perceber a separação entre direito civil e penal ${ }^{5}$. Enquanto aquele visava à reparação, este tinha como plus, além do equivalente ao dano, uma punição. Contudo não tiveram a preocupação, por não haver necessidade, de trazer os fundamentos dessa punição.

Foram filósofos, poetas e literatos da época que escreveram algo sobre a função da pena. Aulo Gélio, levando em consideração a filosofia grega, cita entre as razões de punir: "castigar e emendar (poena adhibetur castigandi atque emendandi gratia)" (GIORDANI, 1982, p. 18); e Sêneca ressalta especificamente a emenda no enunciado "aut ut eum quem punit, emendet" (Idem, Ibidem).

Que tais citações não indiquem que estamos aqui pretendendo defender que a principal função da pena na antiga Roma era a emenda do culpado, pois, ao revés, na maior parte dos textos a ênfase é dada à intimidação. A pena era estabelecida como meio de dissuasão e aplicada como exemplo, como na maior parte da história. O que se quer demonstrar é que, apesar de via de regra sobressair o fim da prevenção geral, a ideia de correção sempre acompanhou o ato de punir. A propósito, se castigo etimologicamente sugere uma pena que “torna casta a pessoa” (ZAFFARONI; BATISTA; et. al., 2006, p. 300), este tornar casta já pressupõe um processo de reforma.

\footnotetext{
${ }^{4}$ Como exemplo, nos registros de condenados de Florença consta que em 16 de novembro de 1629, "Matteo d'Antonio Mariani Fiorentino d'anni 26 fu sentenziato alla forca e per grazia fu liberato e di poi mandato in galera a vita per essere di buona famiglia e civile" (FABBRI, 2004, p. 86-87). Em tradução livre: "Matteo d'Antonio Mariani Fiorentino, de 26 anos, foi sentenciado à forca e por graça foi liberado e mandado em galera perpétua por ser de boa família"

${ }^{5}$ Ou uma atenuação, divisão do próprio direito penal, se entendermos, como Paulo José da Costa Jr., que "o primeiro direito a surgir foi o penal" $(2009$, p. 12).
} 
Platão, em As Leis, foi claro neste ponto: "sempre que alguém comete qualquer ato injusto de grande ou pequena gravidade, a lei o instruirá e absolutamente o compelirá no futuro a não mais deliberadamente cometer tal ação" (1999, p. 369).

Sem fazer maiores considerações sobre a platônica crença em uma lei educativa com tamanho poder de instrução ${ }^{6}$, não é de se estranhar ter sido o filósofo em questão um dos primeiros a deixar para posteridade textos onde há a previsão da possibilidade de se aplicar a pena de prisão, não só como coerção para o pagamento da pena de multa ou para aguardar sanção mais grave, mas como pena de caráter aflitivo independente.

Na mesma obra, Platão (1999) propõe a pena de prisão para o estrangeiro ou escravo que danificar fontes ou templos da praça do mercado, para o descrente dos deuses que são passíveis de uma punição menos grave, e prisão, além de açoites, para o homem até trinta anos e a mulher até quarenta que desrespeitarem os pais.

A primeira técnica elaborada para correção por intermédio da prisão que a história conhece foi realmente de natureza platônica. Para Platão deveria haver três tipos de prisões para correção de criminosos de acordo com o nível da infração, sendo a primeira para a maioria dos casos e poderia ser localizada na cidade, a segunda uma espécie de reformatório e a terceira no "sítio mais selvagem e ermo possível” (p. 431), e com nome que simbolize a ideia de castigo ${ }^{7}$.

Necessário igualmente outra ressalva acerca da aparente benignidade das legislações grega e romana, que estipulavam para muitos delitos a pena de multa como a única aplicável. É que gregos e romanos não impunham a mesma legislação dos homens livres para os estrangeiros, capturados de guerra e escravos. Os homens livres, somente em alguns casos,

\footnotetext{
${ }^{6}$ A doutrina platônica evolui para considerar o efeito de emenda do criminoso, pois antes, da dedução da teoria do sofista Protágoras, considerava somente o efeito da intimidação. Aristóteles, em Retórica, afirmava no mesmo sentido, que "a pena é um meio capaz de atingir a regeneração moral" (COSTA, 1982, p. 27). Alguns discursos de Cícero, na Roma antiga, seguem igualmente a teoria curativa da punição platônica (BAUMAN, 2004).

${ }^{7}$ Embora não encontre exemplos diretos da aplicação independente da pena de prisão, como proposto por Platão em As Leis, até porque na Grécia era elevado o grau de discricionariedade do magistrado na escolha da pena, a prisão como fator coercitivo para o pagamento da pena de multa pode ser vista no Século VI a.C. na Lei sobre o indiciamento de falsários e dos que cometem injúria contra os pais: "E se alguém for detido por maus-tratos infligidos aos pais, ou por falsidade, ou por entrar em lugares proibidos, de acordo com a lei, os Onze devem prendê-lo e levá-lo aos tribunais. Qualquer pessoa elegível pode acusá-lo. Se for considerado culpado, o tribunal deverá avaliar a pena que ele deverá sofrer ou pagar. Se tiver de pagar uma multa, deverá ficar detido até que faça o pagamento desta" (ARNAOUTOGLOU, 2003, p. 115).
} 
principalmente quando o delito era de traição contra o Estado ou era cometido contra pessoa de mais alta estirpe, eram excluídos das penalidades ordinárias e passavam a poder ser objeto de torturas e morte (SCOTT, 2006).

No mais, a própria pena de multa ou mesmo o comum ressarcimento estipulado na maior parte das legislações da antiguidade, caso não houvesse possibilidade de pagamento e ninguém se oferecesse para tanto, poderia se tornar uma pena de prisão perpétua, hipótese em que, diante dos calabouços da época, não se deveria esperar que o culpado sobrevivesse por muito tempo.

Sendo a história comumente feita dos atos e fatos que envolvem as pessoas ligadas ao poder, não é de se estranhar que os registros de leis e decisões judiciais nas antigas Grécia e Roma, apresentem uma menor severidade. A exceção dos cristãos, mártires que puderam escrever sua própria história quando no poder, não se fez maior registro, nem muito menos história dos que não eram considerados cidadãos e eram torturados, marcados a ferros e supliciados.

A estipulação da pena de multa, para a elite somente, reforça a ideia de que legisladores e magistrados traziam constantemente consigo a ideia de correção, uma vez que não se pensaria necessária a manutenção ou a reforma daquele que já era excluído da sociedade, que já era presumidamente um criminoso e o crime deste era mesmo tratado como reincidência.

Para Michel Foucault (2008) não só a ideia de transformação do culpado acompanhou constantemente o intento punitivo do ser humano: também o interesse de segurança e disciplina pode ser encontrado na gênese da punição. O que ocorre é que o homem contemporâneo cresce em torno de uma parafernália criada para a segurança e a disciplina e, quando olha para trás, tem dificuldade de perceber o desenvolvimento desse sentimento e a presença dele em um passado aparentemente com menor criminalidade.

Mais difícil ainda é aceitar que a ideia de correção estava presente nos povos bárbaros. A queda do império romano fez com que a história do ocidente, de suas instituições e práticas, tivesse como precedentes condutas que hoje são tidas como absurdas, renegadas e muitas 
vezes tratadas com desdém, como se elas nenhuma influência tivessem exercido no nosso comportamento atual como indivíduos e sociedade.

Os ordálios ou os juízos de Deus dos povos que dominaram o ocidente são não raramente ridicularizados e neles não se encontra qualquer vestígio de racionalidade. Povos guerreiros, que tinham a honra e a moral guerreiras como maiores valores, acreditavam que Deus, por intermédio da natureza e dos fatos futuros, poderia julgar e estabelecer a verdade de um crime ou uma demanda qualquer.

O exemplo mais comum de ordálio é a prova de fogo, em que o acusado tinha que colocar a mão em um ferro quente ou na água fervente e, passados três dias, não havendo marca, seria declarado inocente. Quanto a tal julgamento, melhor reprisar as circunstâncias que muitos livros não trazem, pelas palavras de quem mais de perto conheceu seus ancestrais:

Quem não percebe que, num povo exercitado no manejo de armas, a pele rude e calosa não devia receber do ferro quente ou da água fervente uma impressão forte o bastante para que esta aparecesse três dias depois? E, se aparecesse, era uma marca de que aquele que passava pela prova era um afeminado. Nossos camponeses, com suas mãos calosas, manejam o ferro quente como querem (MONTESQUIEU, 1996, p. 555).

Ora, mais uma vez a exclusão. Dentro dos valores daqueles povos, quem não preenchia os requisitos não merecia continuar usufruindo do convívio dos demais. Contudo, quem era merecedor de consideração e prestígio, teria passado pela prova do fogo e continuaria entre eles, ou seja, estaria purificado, restaurado ou, porque não, corrigido para seguir sua vida.

A história aparenta ter um vácuo, como se do império romano tivéssemos seguido direto para as atrocidades da Inquisição e dos reis da Idade Média. Mas os povos bárbaros, não obstante terem aprendido a escrita, só aos poucos foram absorvendo usos e costumes dos romanos, inclusive compilando códigos, principalmente pela influência da igreja.

Assim, sem a satisfação de certeza que os juizos de Deus proporcionavam, com a adoção do processo romano, preservado pela igreja nos procedimentos canônicos e adotado pelos reis e povos que iam se convertendo paulatinamente, não é de se estranhar que o procedimento daí originado tenha tido a intolerância e as atrocidades que todos conhecem. A verdade, tão cara aos bárbaros e tão certa por intermédio dos ordálios, passou a ser obtida pela 
tortura, ingrediente dos inquéritos encontrado para extrair a certeza pela confissão. Como bem observa Nilo Batista, “tortura e confissão são companheiras milenares” (2003, p. 33)

Desse complexo casamento entre as práticas da igreja e os povos bárbaros nasceu uma nova mentalidade para a prisão. Ainda servindo como local de espera da pena principal e dos vários suplícios autorizados e inclusive regulamentados, a prisão ganha ao menos no imaginário o caráter de local de meditação, para reflexão e arrependimento, nos moldes dos monastérios, abrindo-se espaço para o nascimento da palavra penitenciária, como até hoje conhecemos (SHECAIRA, CORRÊA JR, 2002).

A atividade legislativa desapareceu do ocidente entre o final do séc. IX e o séc. XII, a exceção de alguns casos esparsos no sul da Europa, mais precisamente na Itália e na Península Ibérica (GILISSEN, 1995), e o casamento que se deu posteriormente entre os costumes bárbaros e a atividade legislativa, o prestígio que o imaginário dos mundos grego e romano manteve, somado à influência da igreja, dificilmente será condensado e explicado de forma satisfatória nos dias de hoje, notadamente no que se refere a influência da religião.

A tendência é interpretar com base em nossos valores, conceitos e preconceitos. Diante da escassez de documentação e atento ao fato de que a escrita na Idade Média era privilégio de pouquíssimos, seria necessária uma atividade verdadeiramente interdisciplinar entre historiadores, arqueólogos, psicólogos, juristas, teólogos etc, para uma aproximação mínima do valor da religião nas regras que os costumes daquela época acabaram formando.

Ademais, nunca podemos examinar um período histórico em contraste com o nosso tempo, mas sim com base na visão do homem da época que estamos examinando. Salutar a advertência de Bertrand Russell, de que devemos lembrar, antes de qualquer coisa, que "em todas as épocas, a maioria das pessoas é constituída de indivíduos comuns, preocupados mais com seu pão de cada dia do que com os grandes temas de que tratam os historiadores" (1972, p. 68).

Por sorte, não é o objetivo deste capítulo, muito menos deste trabalho, fazer uma avaliação do nível de influência da religião nas leis e na atividade punitiva. Quando as leis voltaram a ser escritas ficou fácil perceber, sem muito esforço interpretativo, que a punição continuou trazendo a característica de correção que mostrava no início. As multas 
permaneceram sendo aplicadas nessas primeiras legislações, apesar de paralelas aos juízos de Deus $^{8}$ e a todas as barbaridades e suplícios que a história nos conta.

A dificuldade em se perceber, nos que detinham o poder no passado, a presença do pensamento de recuperação daquele que delinquiu, está na enorme quantidade de pessoas excluídas. Em um sistema feudal, que tem como traço primordial a ocupação de grandes áreas de terra por pequenos grupos de pessoas ou por uma família apenas, é natural que haja um grande número de pessoas excluídas, desnecessárias para o sistema, passíveis de servirem somente como exemplo.

Mesmo assim, a mistura da forte crença em Deus com a atividade julgadora nos traz exemplos interessantes de uma desculpa reformadora nas punições, ainda que o punido fosse alguém supérfluo para o sistema de então e devesse ser excluído com a morte. No ano de 1209, alguns albigenses foram considerados heréticos em uma das cruzadas mais sanguinárias da história, mas na dúvida sobre se submetia um dos acusados à fogueira, "o conde concordou que ele devia ser queimado, alegando que, se ele realmente se arrependesse, o fogo lhe faria expiar os pecados e, se estivesse mentindo, teria o castigo de sua perfídia" (Pierre des Vaux de Cernay apud DUBY, 1988, p. 71).

A reforma viria depois da morte, em virtude da punição. Concepção que, como referido acima, não nos cabe julgar, mas que serve como exemplo de um momento histórico em que os julgadores começam a procurar justificativas para as penas aplicadas. Descabidas para a época ou não, as alegações desses juízes começavam a fundamentar condenações, não para a sociedade, mas suavizando suas consciências perante eles próprios ou perante Deus.

O fato narrado anteriormente se refere à heresia, que na nossa atual percepção é assunto exclusivo da Igreja, embora, no caso daquela cruzada, as denúncias se tenham confundido, vindo a heresia acompanhada de acusações de roubo, homicídio e outras

\footnotetext{
${ }^{8}$ Duby coletou documentos interessantes da Idade Média na Europa, entre eles disposições do Forum de Conche (Fuero de Cuenca), de 1189, onde consta, entre os diversos artigos que: "XI. 33. Aquele que corta os seios de uma mulher. Quem quer que corte os seios de uma mulher pagará duzentos marevedis e será declarado inimigo: se o negar, a demandante escolherá, segundo sua preferência, o juramento de doze vizinhos ou o desafio judiciário (...) XI. 39. A mulher que aborta voluntariamente. A mulher que aborta voluntariamente será queimada viva, se ela o confesar; senão, será absolvida pela prova do fogo" (1988, p. 21-22)
} 
"perversidades"9 (DUBY, 1988, p. 56). A Santa Inquisição nos deixou farto material de processos e sentenças que combinam terror com clemência e morte com vida no além, contudo, há exemplo do mesmo recurso em decisões posteriores que não são relacionadas à atividade religiosa.

Nos EUA, mais de quinhentos anos depois, na Carolina do Sul, um julgamento de pirataria traz situação parecida, quando em 1711, vários marinheiros foram condenados à forca, sendo o Major Stede Bonnet sentenciado da seguinte forma:

Major Stede Bonnet, o senhor está aqui condenado em duas acusações de pirataria. Uma por veredicto do júri, outra por sua própria confissão (...) As leis da virtude são 'maneiras de apaziguar os instintos dos indóceis. Com ela, todos os caminhos levam à paz', Porv. 3.17. O que o senhor não parece ter aprendido com as palavras de Deus que lhe ensinaram na escola, provavelmente devido ao seu descaso, desleixo ou superficialidade. Espero que as presentes aflições que o atormentam o tenham convencido a mudar de atitude. Porque, se insistir em menosprezar os arrependimentos, garanto que, por bem ou por mal, também vai se arrepender. Porv. 3.17. Reconheça que a mão do Senhor lhe pegou. Depois da Justiça dos homens deliberar sobre a punição do corpo, será a vez da alma ir ao Juízo Final. Assim, sendo, com o 'peso de tanta culpa nas costas', Mateus 11.28 o senhor pode estimar que o mais valioso é a reconciliação com Deus. (...) Este tribunal determina que o senhor Stede Bonnet seja levado de volta para a prisão de onde veio e de lá para o local de execução, onde deverá ser pendurado pelo pescoço até morrer na forca. E que Deus de infinita misericórdia tenha pena de sua alma (JOHNSON, 2004, p. 113114).

Manda-se enforcar e ao mesmo tempo se espera uma mudança de atitude do condenado. Nada mais contraditório. Ainda que se alegue uma maior crença na vida após a morte, das pessoas dos séculos passados, a contar pelo medo e desespero dos condenados que a história registrou, tal credo deve ter servido muito mais como justificativa, sobretudo em decisões como esta que já distancia bastante do tempo dos povos bárbaros.

Como bem enfatizou Freud, externalizam-se preceitos da religião e anulam-se assim as verdadeiras intenções (1980). E, no caso, a intenção de matar friamente, com todos os requintes de formalidade da atuação estatal, não pode ser outra se não a exclusão.

Portanto a punição sempre esteve acompanhada de dissuasão, correção e exclusão, servindo as duas primeiras para os que eram ainda úteis à sociedade e a última para os dispensáveis. A grande diferença está em que dissuasão e correção não prescindem de uma

\footnotetext{
${ }^{9}$ Hermann Mannheim cita teoria e doutrina oitocentista de origem religiosa, atribuída a Maine, que equiparava o crime ao pecado, vendo-o como "um corrompimento da comunidade" (1984, p. 68).
} 
certa comunicação, e exclusão é o abandono total do interesse comunicativo, por isso decisões de exclusão tornam-se extremamente carentes de coerência em seus argumentos.

\subsubsection{A prisão como prática}

Partindo do princípio de que a história é algo contínuo e não cindido, poderemos ver o vínculo entre várias manifestações do período feudal na modernidade. É natural que a história oficial tenha pretendido quebrar esse nexo, deixando para o passado as fantasias de cavaleiros medievais, fadas e gnomos, criados especificamente para estabelecer uma diferença definitiva entre os momentos da humanidade.

O crescimento das cidades para além das antigas muralhas resultou em uma preocupação mais acentuada com a segurança, o vínculo com um clã ou uma tribo foi se perdendo e diante da necessidade de proteção do território, e cada vez mais valorizada a propriedade privada, fortalece-se a ideia de Estado e, consequentemente, forja-se um sentimento nacionalista que vem substituir o valor familiar de até então. O sacrilégio não é mais ofender a Deus, mas sim à pátria ou seus símbolos (FROMM, 1964).

O crime não se compara mais ao pecado, mas à quebra dessa obrigação de amor para com a pátria. A quebra da ordem social se confunde com a violação da autoridade nacional. Matar grupos, forjar guerras, colonizar usando o terror, escravizar, continua permissível, desde que contra pessoas de outra nação, enquanto passar fome, aceitar péssimas condições de trabalho, saúde e moradia, são atitudes que se espera de um verdadeiro senso de nacionalidade.

Há pouco se falou de incoerência do sistema. Pois bem, nem o renascimento, nem o capitalismo foram capazes de trazer o mínimo de racionalidade às relações sociais e muito menos à relação do Estado para com o homem. E para que não haja uma quebra de raciocínio referente ao período feudal do qual estávamos falando, interessante trazer um fato colhido por Marx diretamente relacionado à incoerência em uma época de troca de valores na sociedade:

$\mathrm{Na}$ Inglaterra, por exemplo, ainda se condena às vezes, no campo, um trabalhador à prisão por profanação do sábado, por trabalhar no jardinzinho em frente à sua casa. $\mathrm{O}$ mesmo trabalhador é punido pela quebra de contrato, se falta ao trabalho aos domingos, seja mesmo por beatice religiosa, nas usinas metalúrgicas, de papel ou vidro (1988, p. 202). 
De várias ordens são os paradoxos da modernidade, não se resumindo às contradições sociais e econômicas. Uma sociedade hedonista não compactua com a ética do trabalho disciplinado, direcionada para ganhos cada vez maiores. Valores como humanidade, solidariedade e compaixão nos são ensinados aleatoriamente, sem qualquer vínculo com a prática de uma sociedade burocrática que se movimenta na direção do consumo, da busca por posição social, diversão, sexo etc, criando um clima de culpa em que todos desconfiam de todos em uma “devastação da personalidade” (FROMM, 1977, p. 106).

Por isso que é difícil, senão impossível, traçar as razões de ser do nascimento da pena de prisão na sociedade capitalista. Inúmeras obras discorrem sobre o encarceramento, com teses diferentes e algumas contraditórias, contudo não se demonstra admissível especificar um ponto racional que marque o início da conduta punitiva de segregação pura. Parece inclusive que falar de prisão transformou-se em mais um objeto de prazer, pela curiosidade que traz, pela perplexidade, sadismo, masoquismo, medo, horror e tantos outros estados de espírito que provoca, no leitor e em quem escreve, e não nos colocamos isentos de estarmos incluído nesses fatores.

Embalado no interesse que o tema provoca, o cidadão, que não mais acredita na ciência, também tem suas opiniões sobre o cárcere. A prisão é discutida em mesa de bar, em campo de futebol e é objeto de seriados sensacionalistas de TV, em um debate frio e superficial que tem um efeito altamente negativo: as pessoas agem persuadidas de que o que elas conhecem expressa exatamente o que acontece nas prisões (DAVIS, 2003), afastando a possibilidade de um debate sério e coerente.

Nesse caos, as contradições são tantas, sendo a disparidade entre o discurso e a realidade enorme, que qualquer tentativa de explicar o nascimento da pena de prisão de forma definitiva soaria absurda, mesmo a voz partindo de cima de algum critério científico arrogante. Cezar Roberto Bitencourt está certo ao dizer que "quem quer que se proponha a aprofundar-se na história da pena de prisão corre o risco de equivocar-se a cada passo. As contradições que se apresentam são dificilmente evitadas, uma vez que o campo encontra-se cheio de espinhos" (1993, p. 13). 
Inclusive para nós, brasileiros, ouvir falar que a house of correction inglesa, construída em Londres no ano de 1552, para a correção de pobres aptos ao trabalho que se mostravam resistentes, é a raiz da pena privativa de liberdade, como comumente se afirma (MATEOS, 1997), assusta, vez que nossa pátria mãe Portugal tinha degredados e mão de obra escrava suficiente para suprir as necessidades de nossa colonização, e se nossas prisões já tiveram algum intento de formação para o trabalho isso só aconteceu depois de mais de trezentos anos. Nem nosso índio, por vezes preso para ser civilizado, encontrou qualquer instrução nas celas imundas e improvisadas da colônia. Para este bastava o terror da prisão, o ferro em brasa e o chicote, para torná-lo submisso o suficiente para agradar o português.

Dentro de uma realidade exclusivamente européia industrializada é possível fazer uma simplificação, primária, mas condizente com as diversas teorias econômicas existentes. Dissemos anteriormente que o terror da Idade Média era favorecido pela situação feudal, em que um grupo ou uma família podia ocupar um espaço de terra considerável, havendo um excedente de ser humano apto a ser excluído. A partir de então, com o surgimento das indústrias, um pequeno espaço na fábrica deveria alocar várias pessoas, em número muito maior do que o de uma família, razão pela qual não houve mais excedente de ser humano, este devia ser treinado, convocado, arrastado, preso para se adaptar e preencher os espaços da fábrica.

Shecaira e Corrêa Júnior, citando a crítica de Bitencourt à obra de Melossi e Pavarini de que esta traria uma visão marxista limitada, resumem bem outros fatores que aquele relaciona como favoráveis ao surgimento da prisão como pena:

a) valorização da liberdade e destaque para o racionalismo a partir do século XVI; b) necessidade de ocultação do castigo para evitar a disseminação do mal causado pelo delito; c) aumento da pobreza e da mendicância causadas pelas mudanças socioeconômicas, e ineficácia da pena de morte; d) razões econômicas da classe burguesa em ascensão, que precisava ensinar o modo de produção capitalista e, ao mesmo tempo, controlar os trabalhadores, além de garantir mão-de-obra barata em épocas de pleno emprego e altos salários (Op. Cit., p. 35).

Embora algumas dessas circunstâncias já estejam na obra de Melossi e Pavarini, a exceção da primeira, de valor duvidoso, nenhuma das outras afasta a força da análise dita marxista dos autores. Muito pelo contrário, só reforça, notadamente no que se relaciona com uma das conclusões principais que é a de que "a criação desta nova e original modalidade de 
segregação punitiva responde mais a uma exigência conexa ao desenvolvimento geral da sociedade capitalista do que à genialidade individual de algum reformador" (MELOSSI; PAVARINI, 2006, p. 39).

O grande problema é a palavra capitalismo, sobrecarregada de simbolismos que quando não atrapalham a análise científica, prejudicam a interpretação dessa análise. O mesmo pode-se dizer do marxismo, que ampliou sobremaneira a capacidade de exame das estruturas sociais, mas recebeu tantos significados na história que é objeto de inúmeros preconceitos. Se a sociedade burguesa precisou fazer um uso pragmático da força de trabalho e isso levou a que ela, pelo menos por um tempo, incrementasse o valor da vida humana (RUSCHE; KIRCHHEIMER, 2004), este é um avanço que não se pode menosprezar, seja atribuído ao capitalismo, sejam suas mazelas interpretadas com auxílio do marxismo.

Para ficar mais claro e encerrar o assunto que, como se disse, não pode ficar concluído de forma categórica, ou seja, a história da pena de prisão, deve-se esclarecer que no momento em que os reformadores começaram a reivindicar melhores condições para o cárcere e para a prática do Direito Penal como um todo, a prisão como pena já existia. Claro, pois só haveria reformador se houvesse algo a reformar. É que as prisões, ou primeiras casas de correção, algumas administradas por particulares (Idem, Ibidem), não obstante terem tido o objetivo de treinar mão de obra, eram verdadeiros centros de arbitrariedade e promiscuidade, propagadores de doença e sentimento de injustiça.

Daí, fixar o momento do início da pena de prisão é impossível ${ }^{10}$, visto que a arbitrariedade de então não permitiria qualquer colheita de dados ou estatística comprovando que este ou aquele país começou a prender primeiro. Prendia-se e soltava-se aleatoriamente e para tanto, nem carecia ter cometido crime, bastava uma dívida para ser levado à prisão (BENDER, 1987).

Estabelecer o início da prisão como imaginada pelos reformadores é diferente de estabelecer o início da prisão como prática. Nem os reformadores nem o interesse capitalista

\footnotetext{
${ }^{10}$ O Marquês de Sade, recolhido na cela 6 da Torre de Vincennes, em 1778, em uma carta, diz o seguinte sobre a prisão: "A prisão era originariamente um lugar de segurança, onde se encerrava o criminoso antes de executá-lo. Em seguida, por um horrível privilégio de tirania, para fazer sofrer mais o infeliz, resolveu-se deixá-lo apodrecer na prisão, ao invés de matá-lo" (CAMUS, 1974, p. 1224).
} 
de formar dóceis trabalhadores, a prisão nasceu aos poucos, foi surgindo como prática comum, para só depois ser transformada em pena principal de códigos de leis e aparecer como descoberta científica milagrosa para a reforma das pessoas.

Bitencourt explica que por volta de 1552, na Inglaterra, a preocupação do clero com a mendicância fez com que se transformasse o castelo de Bridwell em um local para recolhimento de mendigos, instituição de valor histórico que para muitos marca o início da pena privativa de liberdade. Era um local que, a princípio deveria ter funcionado sob uma rigorosa disciplina, ocupando os seus hóspedes no trabalho têxtil, trazendo vantagens financeiras para o governo. A disciplina não foi mantida por muito tempo, como se verá adiante, mas o prestígio da instituição cresceu e varias bridwells foram construídas com esta ou outras nomenclaturas (1993).

Mas nem sequer as bridwells, houses of correction ou workhouses dos séculos XVI e XVII podem se dar ao luxo de assumir a primazia no ato de prender desocupados, porque desde a Idade Média, ou na história da humanidade inteira, independentemente da escassez ou abundância de trabalho, sempre houve um incômodo entre os detentores de poder contra os que não se incluíam na atividade econômica da época, por isso escravos chegaram a ser melhor tratados do que doentes mentais ou mendigos.

Se o pecado da ociosidade virou matéria prima para as relações capitalistas, o momento exato não será possível precisar. Todavia, não é difícil imaginar, tendo sido o encarceramento dos pobres uma forma de controle social, que passar dessa à prática de manter criminosos presos foi um passo fácil.

De qualquer forma, deter vagabundos e mendigos sempre foi comum, e não foi uma invenção inglesa ${ }^{11}$. Se as houses of corrections tiveram algo de originalidade foi como instituição e não como prática.

\footnotetext{
${ }^{11}$ Duby traz a Ordenação de João o Bom, promulgada em fevereiro de 1351, com o seguinte teor: “...é ordenado que, toda feitura de tal gente ociosa ou jogadores de dados, ou cantadores de rua ou vagabundos ou mendicantes, de qualquer estado ou condição que seja, tendo ofício ou não, homens e mulheres que sejam sãos de corpos e membros, se prontifiquem a fazer alguma tarefa de labor, com que possam a vida ganhar, ou evacuem a cidade de Paris, e as outras cidades do dito Prebostado e Viscondado, dentro de três dias a contar deste pregão. E, se após os ditos três dias aí forem encontrados ociosos, ou jogando dados, ou mendigando, serão presos e levados à prisão a pão, e assim mantidos pelo espaço de quatro dias; e quando tiverem sido libertados da dita prisão, caso
} 
Em Portugal e na Espanha, assim como em suas colônias, a ancestral da pena privativa de liberdade é a pena de galés que, com o tempo foi deixando de ser aplicada porque se foram aperfeiçoando as embarcações. Originariamente, a pena de galés foi considerada um avanço frente à crueldade das sanções medievais, como que inaugurando o utilitarismo dos reformadores (ALBACETE, 1999).

A confusão naquele período era tanta que o Rei Fernando VII, da Espanha, quando percebeu a gravidade da situação dos cárceres, lotados porque não havia mais para onde enviar os presos que antes serviam as galeras, sugeriu à Sala de Alcaldes de Corte y Chancillerías Del Crimen de Valledolid y Granada a possibilidade de se voltar a adotar o antigo regime punitivo, na verdade nunca revogado, de tormentos, desterros e composições de origem medieval, tendo recebido resposta negativa em maio de 1749, quando se propôs o uso dos presos das galés em trabalhos diversos (Idem, Ibidem).

Ainda que os galés, como eram chamados os condenados a essa pena, ficassem presos enquanto não eram utilizados nas naus, o objetivo da pena não era o puro encarceramento. Desnecessários no trabalho nas galeras, os galés passaram a ser esquecidos, superlotando os locais de recolhimento. A partir de então, a utilidade que se viu nos condenados foi a de trabalhos forçados em minas, nos presídios das colônias ou em obras públicas, ocasião em que os presos tinham que se apresentar devidamente acorrentados ${ }^{12}$, condição inapelável da referida pena (GOULART, 1971).

\subsubsection{O nascimento da prisão em Foucault}

A razão de falar separadamente de Foucault quando o tema é a pena de prisão reside no fato de que a sua obra Vigiar e Punir (1998) não se resume a uma análise material do fenômeno punitivo. Foucault deixou feridas na soberba racionalidade moderna, desvendando sentimentos negativos de hostilidade, intolerância e preconceito que estavam bem camuflados nos discursos oficiais autoritários.

sejam encontrados ociosos ou sem bens com que possam manter a vida, ou sem aval de pessoa idônea, sem fraude, para quem façam trabalhos ou prestem serviço, serão postos no pelourinho; e a terça vez serão assinalados na testa com ferro em brasa, e banidos dos ditos lugares" (1998, p. 115).

12 O Código Criminal do Império, que vigeu no Brasil até o final do século XIX, dispunha no seu art. 44 que "a pena de galés sujeitará os réos a andarem com calceta no pé e corrente $\mathrm{d}$ ferro, juntos ou separados, e a empregarem nos trabalhos públicos da província onde tiver sido cometido o delito, à disposição do governo" (PIERANGELI, 2001, p. 242). 
Porque também seu trabalho tem o diferencial de ter sido construído na angústia do próprio cárcere, merece ser abordado em separado. Foucault deu algumas dicas de que a análise crítica de gabinete não é análise nem crítica, pois é afastada da realidade.

Não há os que fazem a crítica e os que transformam, os que estão encerrados em uma radicalidade inacessível e aqueles que são obrigados a fazer concessões necessárias ao real. $\mathrm{Na}$ realidade, eu acredito que o trabalho de transformação profunda pode apenas ser feita ao ar livre e sempre excitado por uma crítica permanente. (2004, p. 10).

Então, o filósofo francês conheceu os cárceres, engajou-se no movimento de reforma penitenciária e, principalmente, ouviu os encarcerados. Vigiar e punir foi escrito quatro anos depois de Foucault formar o Grupo de Informações sobre as Prisões, um grupo que uniu magistrados, advogados, jornalistas, médicos e psicólogos, e "elimina a separação que existe entre o interior e o exterior da prisão" (BILLOUET, 2003, p. 140).

O grupo atuou sob a coordenação de Foucault de 1971 a $1974^{13}$, tendo sido considerado responsável por uma série de revoltas em mais de 35 prisões. Juntaram-se ao grupo personalidades como Jean-Paul Sartre, Gilles Deleuze, Claude Mauriac, Michele Vian e Alain Joubert, que inclusive participaram de um sit-in no hall do Ministério da Justiça francês em 1972 (DELEUZE, 2006). Posteriormente, Foucault passa a atuar somente por intermédio da imprensa e em seminários, militando inclusive contra a pena de morte, fícando o movimento a cargo da Comissão de Ação de Presos a partir de 1974 (BILLOUET, 2003).

A transdisciplinaridade foi o que buscou Foucault, pois ele queria apenas uma "transposição de fronteiras dos diversos ramos do conhecimento e das diversas ciências, em busca de uma visão mais abrangente, mais holística do cárcere e dos encarcerados" (SÁ, 2007, p. 186), e fez isso reconhecendo e reivindicando os direitos e as qualidades de cidadãos dos presos.

A falta de consciência política tanto do encarcerado quanto de representantes do Estado faz com que tudo se resuma à violência, sem qualquer perspectiva de mudança, mas tão somente de confronto. Para Pierre Billouet, o texto de Foucault seria resultado da indignação:

\footnotetext{
${ }^{13}$ Para se ter uma noção das prisões francesas da década de 1960, Combessie nos fala da prisão de Clairvaux, um velho mosteiro, com "estruturas austeras e insalubres (...) À noite, eram trancados nos 'galinheiros', celas de madeira que continham um prisioneiro cada, de aproximadamente dois metros quadrados” (2004, p. 134).
} 
“já que a prece é inoperante e a ironia impotente, nada mais resta que a revolta" (2003, p. 151).

Seguindo o seu perfil nietzschiano, Foucault propõe, sem descartar os diversos fatores já citados, que os suplícios não deixaram de ser ostentados por humanismo, mas sim porque a multidão começava a se identificar com o criminoso, trazendo a possibilidade de tumultos, "além das gritarias e aclamações que o povo normalmente faz, o medo de que houvesse desordem, violência e impetuosidade contra as partes talvez até mesmo contra os juízes” (1998, p. 33). Tudo isso foi fazendo o suplício deixar as praças. Afinal, uma falha na execução poderia ser tida como diminuição do poder do rei.

A partir de então começa o que ele chama de "colonização da penalidade pela prisão" (1998, p. 97), surpreendentemente, “como uma instituição de fato, quase sem justificação teórica" (2009, p. 83), ficando as demais penalidades relegadas a segundo plano. Os trabalhos forçados, a deportação e algumas espécies de talião foram vagarosamente sendo abandonados em prol da pena de prisão.

Mas a prisão continuou marcada pelos abusos de poder. Após a sentença o condenado era entregue à administração penitenciária e assim prosseguia sem qualquer controle, possibilitando "castigos secretos e não codificados pela legislação, um poder de punir que se exerce na sombra" $(1998,107)$, portanto tão despótico quanto o anterior, tão arbitrário que poderia comprometer toda a estratégia punitiva.

Em seguida, a visão foucaultina é de que o poder se diluiu, enraizou-se na sociedade, no que foi chamado de economia política do corpo $^{14}$, a qual levará à criação de micropoderes que alcançam o ser humano no seu mais minúsculo gesto, o seu modo de ser ou de falar, comportamentos ou atitudes. No campo penitenciário, as disciplinas disputarão o espaço escuro e promíscuo que ficou vago, propício para a ampliação do exercício do poder punitivo.

A tendência de se achar que todo poder só se origina do Estado faz com que não se percebam os diversos mecanismos e efeitos de poder que não passam necessariamente pelos

\footnotetext{
${ }^{14} \mathrm{O}$ termo economia politica do corpo Foucault teria apreendido da obra de Rusche e Kirchheimer (DIDIER, 1994, p. 394)
} 
aparelhos de Estado (FOUCAULT, 2005), mecanismos que elevam ao máximo a força do poder.

Foucault assinala que esses micropoderes não estão localizados em nenhum lugar específico da estrutura social; eles se encontram nessa rede de dispositivos de que ninguém escapa. Por isso ele afirma que o poder não é algo que alguém detém como uma propriedade; o poder se exerce. Portanto, não existe O Poder, mas práticas ou relações de poder. (VILAS BOAS, 1993, p. 79).

A importância da disciplina e de todas as instituições disciplinares surge como mecanismo útil em uma sociedade que sucedia o período feudal, em uma sociedade capitalista na qual a multiplicidade de relações não poderia ser regulada com os instrumentos medievais de outrora. Nesse contexto, teria nascido a pena de prisão, como consequência óbvia do novel e extremo valor que se passa a atribuir ao tempo, em contraste com a repulsa que se passa a sentir contra a ociosidade.

Como não seria a prisão a pena por excelência numa sociedade em que a liberdade é um bem que pertence a todos da mesma maneira e ao qual cada um está ligado por um sentimento "universal e constante"? Sua perda tem portanto o mesmo preço para todos; melhor que a multa, ela é o castigo 'igualitário'. Clareza de certo modo jurídica da prisão. Além disso ela permite quantificar exatamente a pena segundo a variável do tempo.(FOUCAULT, 1998, p. 196).

Interessante que Foucault, ao explicar ser a prisão facilmente adaptável à nossa sociedade de princípios econômicos, diz como é frequente a expressão relacionada à prisão: pagar sua dívida (Idem, Ibid). Curioso porque qualquer um que conhece algo do meio carcerário sabe mesmo como são comuns expressões desse tipo, construídas de formas diversificadas pelos próprios detentos, que não cansam de declarar ${ }^{15}$ : eu já paguei mais do que devia; eu já paguei o meu castigo etc ${ }^{16}$.

O mais grave é que a cultura do devo e pago se contrapõe à cultura do não devo não pago que se alastra no meio social. Os que vivem em liberdade não devem nada e, portanto, anula-se a possibilidade de uma conduta ética e política de solidariedade, pois se não se deve nada, não se deve nada a ninguém e, por fim, é cada um por si.

\footnotetext{
${ }^{15}$ Na pesquisa com presos do Rio Grande do Sul, de Maria Palma Wolff, "a idéia de 'pagamento de uma dívida' apareceu em quase todos os depoimentos" (2005, p. 77).

${ }^{16}$ Comparação nesse sentido pode ser feita com o passado de caráter religioso da pena: enquanto hoje se fala em pagar a pena, na sentença que condenou Tiradentes à forca, de 1792, está expresso que os réus que foram absolvidos assim o foram porque tiveram o tempo da prisão purgado, como se pecado fosse (TRISTÃO, 1999); ou seja, hoje paga-se, antes se purgava.
} 
O tempo como conteúdo da punição igualmente dá uma ideia de operação matemática que tranquiliza legisladores e juízes, mas o tempo, deve-se ressaltar, diferentemente do que pode parecer, não é objetivo: o sofrimento causado pela perda da liberdade não varia somente em razão do tempo, sendo este às vezes um fator de somenos importância; a dor e o sofrimento têm razões de intensidade incalculáveis com base no tempo.

Foucault lembra que "quando os prisioneiros começaram a falar, viu-se que eles tinham uma teoria da prisão, da penalidade, da justiça” (2005, p. 72), algo que a ciência jurídica teima em não reconhecer. O preso, ainda que seja tratado como objeto por legisladores e juízes, tem sua concepção de justiça, raciocina e avalia o seu contexto, o que torna a indiferença do sistema prejudicial a qualquer pretensão comunicativa.

O que há na hipótese foucaultiana é uma pena que se adaptou aos novos valores. Onde o tempo é primordial e pode ser estimado em dinheiro, a única forma de se punir o excluído é com o tempo. Embora tenha havido projetos de inclusão em um mecanismo manifestamente excludente, estes foram passageiros, naturais das circunstâncias do momento.

A pena de prisão sempre foi e continua sendo pura exclusão e seu poder corretivo é o mesmo dos terrores da antiguidade e da Idade Média, originado do medo, medo este cada vez menos presente, cada vez mais ignorado. Como os suplícios, que perderam a graça, foram deixando de ter efeito, a prisão vai seguindo o mesmo caminho. Vulgarizada, vai se tornando uma punição sem qualquer efeito dissuasório, mas tão somente de exclusão.

A vantagem de uma análise como a de Foucault é colocar o nascimento da prisão dentro de uma dialética histórica, fazendo-nos pensar até quando a sociedade ficará estagnada em um método punitivo que já faz mais de três séculos. Se a prisão foi um avanço, é chegada a hora de superá-la, reservando-a, quando muito, para casos de extrema necessidade.

Com relação ao Brasil, uma das observações que se pode fazer na leitura de Vigiar $e$ Punir é a de que não tivemos muita influência dos reformadores iluministas, o que não é de se estranhar tendo em vista que nossa história é superposta de vários períodos ditatoriais, sendo todos os avanços atribuídos mais à imitação de legislações estrangeiras e às concessões dos regimes autoritários, do que à prática concreta e voluntária inerente ao debate político democrático. Sem contar que, no início, os princípios iluministas tiveram que conviver com o 
massacre de nossa população indígena e com a escravização do negro. Então, mesmo certas conquistas básicas de direitos, oriundas do nascimento dos primeiros sistemas penitenciários, são difíceis de ver por aqui ${ }^{17}$.

Contudo, o principal argumento reformador, nem aqui nem em canto nenhum pode ser tido como razoável. A crítica nesse ponto é óbvia, pois deriva de conclusões lógicas:

Essa ideia de aprisionar para corrigir, de conservar a pessoa presa até que se corrija, essa ideia paradoxal, bizarra, sem fundamento ou justificação alguma ao nível do comportamento humano tem origem nessa prática [...] Essa ideia de uma penalidade que procura corrigir aprisionando é uma ideia policial, nascida paralelamente à justiça, fora da justiça, em uma prática de controles sociais ou em um sistema de trocas entre a demanda do grupo e o exercício do poder (FOUCAULT, 2009, p. 9899).

Deixa-se de referir aqui especificamente as abordagens de Foucault sobre as ideias dos diversos reformadores, visto que será assunto a ser tratado a seguir. Insta ressaltar, como conclusão parcial, todavia, que Foucault não foi só pessimismo. Ao concluir Vigiar e Punir falando de "múltiplos dispositivos de "encarceramento" (1998, p. 254) e, acreditando poder combatê-los, nada mais fez do que deixar uma lição de esperança. Sua angústia e ironia são atributos de quem ainda está vivo e sonhando, porque, quando não se acredita mais em nada, o que temos é o silêncio.

\subsubsection{Primeiros reformadores}

A dificuldade de se estabelecer o início da prisão como pena é comparável com a penosa tarefa de se determinar quem foram os primeiros reformadores que se preocuparam com as péssimas condições do cárcere. Antes de tudo porque sempre houve dois tipos de preocupações, a primeira relacionada à lei e a segunda diretamente ligada às condições materiais da prisão. Mas também porque a prisão, a despeito da dificuldade de saber do seu nascimento, já foi concebida defeituosa e, portanto, sempre esteve fadada a ser objeto de reforma.

\footnotetext{
${ }^{17}$ Exemplo é a norma do Motifs Du Code d'instruction criminelle, que Foucault traz como informação: "Como a lei inflige penas umas mais graves que outras, não pode permitir que o indivíduo condenado a penas leves se encontre preso no mesmo local que o criminoso condenado a penas mais graves" (1998, p. 197); regra que, principalmente após a entrada em vigor da Lei de Crimes Hediondos (8.072/90), nunca foi cumprida, pois as penitenciárias brasileiras jamais fizeram qualquer separação entre os condenados que cumprem pena no regime mais grave previsto nesta lei e os demais apenados por crimes comuns, isso sem querer trazer exemplos de prisões que recolhem juntos presos provisórios e condenados e até mulheres e homens. Voltaremos a falar sobre essa questão no item 3.5.2.
} 
A prisão, enquanto não for extinta, estará sendo reformada. Se fosse possível uma arqueologia da prisão, encontraríamos o seu primeiro reformador nos escombros da primeira casa de correção, porque sempre houve alguém com o mínimo de humanidade e espontaneidade suficientes para uma conduta de compaixão ou solidariedade para com os presos, principalmente quanto mais imundo e aterrorizante é o cárcere. Assim, a história da prisão deixou e ainda deixará para trás muitos reformadores anônimos.

Como já referido, a história se faz pelos que escrevem a história, por isso nesta estarão sempre os que participaram de alguma forma do poder. Esse é o motivo por que são considerados os primeiros reformadores os que alguma influência tiveram frente aos poderes da época, seja na esfera legislativa, seja na administrativa, interferindo nas condições materiais dos presos.

\subsubsection{Reformador de prisões: John Howard}

As prisões do século XVIII não eram como as que vemos hoje, embora no Brasil não seja muito difícil imaginá-las. Eram grandes casarões com administração doméstica, onde ficavam misturados desde testemunhas, detidas para posteriormente serem encaminhadas à corte, até devedores, pessoas aguardando julgamento, criminosos comuns e condenados à morte (BENDER, 1997), um verdadeiro depósito ${ }^{18}$. Presos que eram considerados inocentes, permaneciam detidos quando não tinham dinheiro para pagar as taxas devidas ao carcereiro.

A situação de abandono dos presos, ao mesmo tempo em que era causa de doenças e fome, era propícia à liberalidade. Jogos, apostas, bebidas, festas, fugas, tudo era possível ser encontrado ou comprado nessas prisões. Com isso, a maior parte desses primeiros reformadores não estava preocupada em trazer melhores condições para o encarcerado, mas sim incomodada com a grande libertinagem do local.

A maioria dessas situações, que se conhece das prisões do século XVIII, foi legada por um desses nomeados reformadores, John Howard, que de todos foi o que realmente esteve nos cárceres. Sua obra, na qual narra a situação das prisões da Inglaterra, evidentemente escrita

\footnotetext{
${ }^{18} \mathrm{O}$ excelente trabalho de John Bender, Imagining the Penitentiary (1997), traz o exemplo e foto da York County Gaol, a primeira casa especificamente desenhada para ser uma prisão na Inglaterra, de 1705, a qual se assemelha aos antigos casarões ingleses.
} 
para que as autoridades tivessem conhecimento do que ocorria nas prisões inglesas, tornou-se o livro The State of Prisions in England and Wales (1777).

Evitando repetir o já dito sobre Howard e respeitando o limite estabelecido pelo tema deste trabalho, ou seja, avaliar indícios, na história da pena, do interesse na correção do ser humano, que originou o termo conhecido por ressocialização, bem parece que Howard não teve muito tempo para tais lucubrações. Suas preocupações eram sinceras e derivadas das condições sub-humanas do cárcere inglês e, como verdadeiro filantrópico, seu tempo foi gasto primordialmente na atividade de apoio material aos encarcerados.

Quando, em sua obra, Howard fala do que é pernicioso para a moral, ele se refere à promiscuidade dos presos, à mistura entre homens e mulheres, entre sãos e enfermos e devedores e criminosos; portanto, o apelo do autor à moral não demonstra um profundo exame filosófico sobre as finalidades da pena. Ao invés, indica que a situação de calamidade era tanta que todos os argumentos deveriam ser usados para sensibilizar as autoridades, por isso não vejo como considerá-lo um correcionalista ${ }^{19}$, como fez Jimenez Asúa (BITENCOURT, 1993). Inclusive Howard chega a afirmar: “muitas vezes se diz que 'a prisão não paga dívidas', mas eu tenho certeza de também poder ser dito que a prisão não emenda a moral"20 $(1777$, p. 20). Certamente Howard gostaria de reparar era a miséria com que os presos eram tratados e não sua moral.

Embora em uma ou outra passagem de seu livro haja referência à questão moral que, além de ser uma súplica às autoridades, mais facilmente, inclusive ou sobretudo nos dias de hoje, sempre contraditoriamente propensas a dar mais valor a disciplina moral dos presos do que à situação desumana com que são tratados, não se pode esquecer que a prisão estava nascendo como pena, não tinha os seus trezentos anos de história de hoje, e quem supusesse que poderia ser uma sanção viável, cometia um erro perdoável.

O Direito Penal e o Direito Penitenciário deram ênfase às reivindicações de caráter legal de Howard, porque ele, avançado para o seu tempo, foi o primeiro a solicitar o fim das

\footnotetext{
${ }^{19}$ A teoria correcionalista seria aquela que defende que o objeto da pena é melhorar o sujeito que delinquiu, fazendo um bem tanto para o indivíduo como para a coletividade (HADDAD, 1999).

${ }^{20}$ No original: 'It is often said, 'A prison pays no debts;' I am sure it may be added that a prison mends no moral” (HOWARD, 1777, p. 20).
} 
taxas de carceragem, a necessidade de inspeções periódicas, a classificação de presos, entre diversos outros direitos que até hoje têm dificuldades de implementação, tendo sido considerado o precursor da ciência penitenciaria (MIOTTO, 1992), muito embora em sua obra haja observações de caráter criminológico raramente ressaltadas, como noções básicas de ser o cárcere criminógeno.

Howard conta que em muitas prisões nem o administrador entra na área onde estão os presos e que há locais em que os próprios detentos guardam as chaves das celas; narra a dificuldade dos presos que são liberados em conseguir emprego, apesar da existência de trabalho ${ }^{21}$; denuncia que prisões têm que ser adaptadas em razão das péssimas condições de manutenção do prédio, onde muitas vezes falta até água; informa que apesar de alguns presos serem obrigados a trabalhar, não há material nem ferramenta para tanto nas prisões. Assim, duzentos e trinta anos depois, qualquer semelhança com a atualidade não é mera coincidência.

Howard passou por uma experiência de privação de liberdade, preso por corsários franceses em 1756 quando fazia uma viagem a Portugal e confessa em sua obra que talvez o que ele "sofreu naquela ocasião, tenha influenciado na sua simpatia por essas infelizes pessoas, objeto deste livro"22 (1777).

Circunstância a respeito da qual não se pode ter dúvida, pois a experiência demonstra, com tantos anos dessa prática punitiva no Brasil, que as pessoas só podem verdadeiramente demonstrar preocupação com o cárcere quando o conhecem de perto. Um dos efeitos bem descoberto por Foucault sempre esteve presente: a prisão substituiu o suplício para diminuir o sofrimento da sociedade, dos juízes, promotores, mas não do condenado.

O que se deve concluir sobre Howard é ser um erro considerar sua obra uma ode à recuperação do preso. O que mais incomodava o autor era que se as leis eram feitas e os juízes prendiam, legisladores e magistrados deveriam saber a verdadeira situação das prisões, a qual

\footnotetext{
${ }^{21}$ Nas palavras de Howard: "the poor acquitted prisioner shall go from door to door asking for work, in vain (1777, p. 39).

${ }^{22}$ No original: "Perhaps what I suffered on this occasion, increased my sympathy with the unhappy people, whole case is the subject of this book" (p. 23). Todavia, logo que chegou de viagem, Howard passou a ter contato com as prisões em razão de ter sido nomeado sheriff do condado de Bedford, em 1773 (BROWN, 1823).
} 
desvirtuava qualquer interesse de justiça ${ }^{23}$. Portanto, Howard não era um entusiasta da prisão, apenas desejou vissem que aquela prisão desumana só levava a consequências perversas.

Se ele era religioso e chegou a ver a religião como meio de reforma moral (MAYRINK, 1982), não foi por intermédio da prisão, em hipótese nenhuma. Ocorre que suas ideias de reforma da situação prisional foram usadas pelos que, depois dele, construíram a ciência penitenciária sob as bases do ideal reformador do ser humano, o que demonstra o caráter arbitrário sob o qual algumas ciências são construídas.

Em consequência de sua luta, quando se preparava para visitar o extremo oriente, Howard morre em 20.1.1790, em Kherson, Criméia, acometido da doença das prisões, uma espécie de tifo (MIOTTO, 1992).

\subsubsection{Reformadores de leis: Beccaria e Bentham}

Diferentemente de Howard, as outras duas personalidades consideradas entre os primeiros reformadores, Beccaria e Bentham (BITENCOURT, 1993), tiveram uma preocupação mais abstrata com o sistema penal, não obstante o incontestável poder de influência que obtiveram. Por isso inclusive não haveria como resumir seus trabalhos de caráter filosófico em poucas linhas, razão pela qual mais uma vez o limite será o tema deste trabalho: saber se das mensagens desses pensadores iluministas pode ser tirado algo que justifique a ideia atual de ressocialização por intermédio da prisão.

Vale, contudo, a mesma observação feita com relação a Howard. Estes filósofos, embora de épocas diferentes, buscavam ainda superar o período macabro da Idade Média e toda a racionalidade e humanismo presentes nos seus textos se confundiam com certo medo e apelo à superação de tanta barbaridade. Howard e Beccaria, inclusive, chegaram até a ser acusados de certo sentimentalismo e exagero humanitário, por Ferri, no início do século XX (PIRES, 1998).

A obra de Cesare Bonessana, o Marquês de Beccaria, Dos delitos e das penas (1999), é o clássico do Direito Penal, foi publicada pela primeira vez anonimamente em 1764 e não

\footnotetext{
${ }^{23}$ Nas palavras de Howard: "the Legislature will be better acquainted with the real state of Goals; and Magistrates will be able to judge whether the Prisons over which they preside, and to which they commit offenders, be fit for the purposes they are designed to answer" (1777, p. 150).
} 
traz qualquer referência à prisão como pena; cita a prisão anterior ao julgamento, masmorra onde a humanidade iluminista não penetrou, mansões de "desolação e fome" (BECCARIA, 1999, p. 98). Refere-se ao abuso que se fazia na prática de prender, da qual juízes criminosos se aproveitavam como forma de vingança contra inimigos pessoais, mas nunca à possibilidade de recolhimento com tempo e objetivos determinados. A prevenção em Beccaria, por sinal, é sempre a prevenção geral, servindo a pena estipulada na lei como forma de dissuasão, nada mais. Mesmo depois, na sua atividade de administrador, suas manifestações com relação à prisão foram primordialmente de cunho humanitário, bem distantes de qualquer característica reeducadora $^{24}$.

A preocupação de Beccaria com o bem geral, com o cumprimento das leis, consideradas, em uma concepção contratualista, resultado do acordo comum de todos, levou ao reconhecimento do infrator como um culpado pela quebra desse contrato, portanto um culpado que merecia castigo, uma punição que deveria ser justa e rápida para evitar qualquer sentimento de impunidade, mas era de antemão merecida. O contrato era a garantia das liberdades que estavam sendo alcançadas e violar esse contrato era seguir na contramão dessas liberdades. A propriedade, não abrangida pela proteção do direito natural, precisava ser respeitada, e a construção desse respeito se deu por intermédio do contrato social.

Enquanto a filosofia iluminista, instrumento da emergente classe burguesa, era difundida nas artes, na política, nas ciências de um modo geral, o Direito Penal permanecia abandonado dessa racionalidade, um depósito das antigas práticas e, por isso mesmo, ameaça para a segurança dos que tinham novas propostas e queriam mudar o mundo. Montesquieu, Voltaire, Rousseau, Beccaria e todos os outros, não se interessaram pela irracionalidade do sistema à toa, eles poderiam ser vítimas dessa irracionalidade, e muitos o foram.

\footnotetext{
${ }^{24}$ Como exemplo da preocupação humanista de Beccaria relacionada ao cárcere, em momento posterior à sua célebre obra, quando representante do poder estatal em Milão, encontramos uma resposta à consulta sobre a situação das correntes dos presos da Penitenciária de Pizzighettone, em 1791: "Igualmente com referência ao alongamento das correntes, concordou-se com a opinião do Régio Diretor, que sendo hoje a respectiva corrente de somente quatro braças, pode ser alongada em mais dez braças, com a ressalva, porém, de que o cadeado que atualmente se prende aos ditos condenados a fim de os prender ao muro, representando um enorme peso para os próprios condenados, possa, ao contrário, ser preso á grande argola fincada no muro próximo da terra, e não no alto, para que os condenados não tenham de suportar o peso do próprio cadeado, e possam passear mais comodamente" (2006, p. 55).
} 
Sabemos, porque convivemos com elas, que várias irracionalidades sobreviveram à revolução burguesa e assim como assustavam na sociedade moderna que despontava, assustam hoje. Pena não assustarem os que agora não estão mais ameaçados ou, no dizer de Frank Süb, “agora só se considera delinquente potencial o "outro"” (2000, p. 243). Os descendentes dos revolucionários do Estado de Direito estão seguros.

É como se o contrato social os tivesse excluído de qualquer ameaça. Um contrato com cláusulas leoninas que vieram para proteger a propriedade, os proprietários e excluir os despossuídos. Ou, como fala Baratta, “um 'pactum ad excludendum', de um pacato entre a minoria dos iguais, que excluiu da cidadania todos os que são distintos: um pacto entre proprietários brancos, homens e adultos para excluir e dominar indivíduos pertecentes a outras etinias, mulheres, crianças e pobres" (1995, p. 124).

Falando de prisão e de Beccaria, não poderíamos deixar passar a oportunidade de citar textualmente uma advertência sua que, entre outras, vergonhosamente mantém a atualidade:

Se a prisão é apenas um meio de deter um cidadão até que ele seja julgado culpado, como esse meio é aflitivo e cruel, deve-se, tanto quanto possível, suavizar-lhe o rigor e a duração. Um cidadão detido só deve ficar na prisão o tempo necessário para a instrução do processo; e os mais antigos detidos têm direito de ser julgados em primeiro lugar. $\mathrm{O}$ acusado não deve ser encerrado senão na medida em que for necessário para o impedir de fugir ou de ocultar as provas do crime. $\mathrm{O}$ processo mesmo deve ser conduzido sem protelações. Que contraste hediondo entre a indolência de um juiz e a angústia de um acusado! De um lado, um magistrado insensível, que passa os dias no bem-estar e nos prazeres, e de outro um infeliz que definha, a chorar no fundo de uma masmorra abominável (2003, p. 58) ${ }^{25}$.

A quantidade de presos provisórios que amontoamos em nossas cadeias, maculando um Estado que tem como fundamento a dignidade da pessoa humana, falam por si, pelo que a citação acima prescinde de qualquer comentário. A história provou a importância do trabalho desse italiano, mas as gerações que vieram depois não podem atribuir a ele o valor que se dá à prisão hodiernamente.

\footnotetext{
${ }^{25}$ Foram usadas duas traduções neste trabalho. Tendo em vista a diferença entre elas, segue o texto original: "Il cárcere è dunque la semplice custodia di um cittadino, sinchè sia giudicato reo; e questa custodia essendo essenzialmente penosa, deve durare il minor tempo possibile, e deve esser meno dura che si possa. Il minor tempo è dalla necessaria durazione del processo, e dalla anzianità di chi prima ha un diritto di esser giudicato. L'angustia del carcere non può essere che la necessaria, o per impedire la fuga, o per non occultare le prove dei delitti. Il processo medesimo deve esser finito nel più breve tempo possibile. Qual più crudele contrasto, che l'indoleza di un giudice, e le angosce di un reo? i comodi e i piaceri di un insensibile magistrato de una parte, e dall'altra le lagrime e lo squallore di um prigioniero?” (BECCARIA, 1786, p. 81-82).
} 
Álvaro Pires, citando Braive, afirma que, enquanto Beccaria nunca foi um puro utilitarista, Bentham é o protótipo (1998). Jeremy Bentham nasceu em Londres no ano de 1748 e morreu em 1832, era, portanto, dez anos mais novo que Beccaria e morreu trinta e oito anos depois, em 1832 (BITENCOURT, 1993), e com uma obra mais extensa que a de Beccaria, fez realmente jus à classificação de utilitarista.

Para o Direito Penal e Penitenciário, sua elaboração mais famosa é a do Panóptico, um projeto de casa de detenção que serviria para uma vigilância diuturna dos presos. Seria circular, as celas ocupariam a circunferência e haveria um vigia no centro que poderia fiscalizar os presos sem ser visto. Tal construção serviria para "punir o incorrigível, encerrar o insano, reformar o viciado, confinar o suspeito, empregar o desocupado, manter o desassistido, curar o doente, instruir os que estejam dispostos" (BENTHAM, 2000, p. 16).

A ideia de Bentham sobre esse mecanismo disciplinar, descoberto por Foucault em Vigiar e Punir (1998), foi a deixa para o francês criar o simbolismo que ele denominou de sociedade disciplinar ou sociedade panóptica, na qual surgiram os diversos exames classificando doentes, loucos, criminosos, estudantes, militares etc. Foucault chega mesmo, em outra ocasião, com sua ironia costumeira, a pedir desculpas aos historiadores da filosofia por acreditar "que Bentham seja mais importante para nossa sociedade do que Kant, Hegel etc. Ele deveria ser homenageado em cada uma de nossas sociedades" (FOUCAULT, 2009, p. 86).

A importância filosófica de Bentham, no entendimento de Foucault, está no fato de que o projeto panóptico serviu para que entendêssemos o quanto nossa liberdade continua limitada, controlada por mecanismos disciplinares invisíveis que nos classificam, permitindo a exclusão ou inclusão. Tudo isso independentemente da atividade direta do Estado.

Mas, procurando não fugir do tema que nos interessa, o Panóptico acabou também sendo reconhecido como a principal contribuição de Bentham para a criminologia (HAGAN, 2011). Para Manheim, Bentham é um dos pioneiros da criminologia e na maioria dos livros ingleses de criminologia Bentham é indicado como um dos reformadores da legislação criminal, o mesmo para os historiadores, que ressaltam a sua influência em diversas legislações posteriores ao seu trabalho (GREENBERG, 1984). 
Contudo, a preocupação de Bentham para com as prisões e os encarcerados estava incluída nos seus cálculos utilitaristas. Na Inglaterra diminuía a aplicação da pena de morte, restringia-se a deportação e os cárceres iam ficando cada vez mais lotados (PERROT, 2000), portanto seriam necessárias medidas, não por questão de humanidade, mas por cálculo mesmo, para que a situação não se agravasse.

O excesso de utilitarismo de Bentham fazia com que o valor do indivíduo fosse menor do que o valor que ele atribuía aos interesses sociais. As suas orientações de reformas para a legislação seguiam no sentido de se alcançar a maior vantagem para o maior número de pessoas e, assim, a sua concepção do criminoso era a de que este cometia delitos porque a vantagem que via no ato criminoso era maior do que o receio da punição. O corolário disso era que, para Bentham, a punição deveria ser rigorosa o suficiente para afastar o interesse do prazer que o criminoso via no crime (VITO, 2006).

Conquanto em alguns pontos os cálculos de Bentham possam ter levado a consequências tidas como humanistas, ser humanitário não era o seu intento, mas sim ser objetivamente utilitarista. Quando Bentham defendeu a correção moral, o fez por intermédio de penas duras e severas, o mal pelo mal na medida do que ele entendia por necessário. Por isso a prisão, em alguns casos, deveria ter isolamento, ser escura e impor ao preso uma dieta mais rigorosa no fim da pena, para que a sensação de sofrimento permanecesse (BENTHAM, 2002).

A prevenção geral, a punição para intimidação e a correção pelo mal foram a base das ideias de Bentham. O próprio Panóptico tinha a disciplina como elemento essencial não para disciplinar puramente, mas para causar dor e arrependimento. O mesmo sentido de correção que se viu em toda a história, permanecia em Bentham.

Se o simbolismo do Panóptico fez com que criminologistas entendessem que aquilo era um avanço na direção da recuperação do preso, fizeram uma mais uma interpretação arbitrária para fundamentar seus próprios interesses. Contudo, Bentham era prolixo em simbolismos e se palavras não podem contra um símbolo, podemos buscar outros que demonstrem o despautério de sua concepção de punição justa. 
Ao falar das penas aflitivas, Bentham se demonstra incomodado porque os açoites ficam a critério do executor, que os pode maneirar ou agravar conforme seu interesse pessoal ou financeiro, destruindo a intenção do juiz e favorecendo os que mantiveram os objetos furtados em detrimento dos que devolveram o resultado do crime, porque aqueles podem pagar uma seção de açoites menos severa. Se perguntando se seria possível emendar este abuso, Bentham propõe um invento tão criativo quanto o Panóptico:

Não acho difículdade na invenção de uma máquina cilíndrica, que pusesse em movimento corpos elásticos, como juncos, ou barbas de baleia, que fustigassem com a mesma força, e dessem tantos golpes, quantos determinassem o juiz da sentença: por este modo já a execução do castigo não vinha a ser arbitrária. Um oficial público, que tivesse caráter, estaria presente; e no caso de o réu ter mais companheiros no crime, podia haver outras tantas máquinas que fizessem o mesmo: um semelhante espetáculo, representado ao mesmo tempo, causaria um terror mais considerável, sem acrescentar coisa nenhuma à pena real (BENTHAM, 2002, p. 64).

Portanto, retirar de Bentham fundamento para o que hoje se chama de ressocialização é atitude que carrega consigo extrema parcialidade. As concepções utilitaristas de Beccaria e principalmente as de Bentham podem igualmente ser consideradas a base de algumas ideias humanitárias modernas, como podem ser tidas como a base das ideias antropológicas e estigmatizantes da criminologia positivista, a respeito da qual falaremos em seguida. A escolha foi feita arbitrariamente e a ciência se construiu omitindo várias circunstâncias, criando e mistificando heróis onde só havia seres humanos com seus defeitos e enganos. Até aqui é inexistente qualquer fundamento científico para uma pena de prisão ressocializadora. As ideias foram para reformar prisões e leis, não seres humanos.

\subsubsection{Escola positivista}

O pensamento liberal trouxe para o sistema punitivo diversas garantias, mas o pretendido tratamento isonômico, somado a uma prática punitiva que continuava destruidora, não permitiu ao direito penal perceber que o verdadeiro protagonista, o criminoso, ficava cada vez mais distante das considerações científicas.

Mas a arrogância do ser humano não tardou a encontrar na prisão um vasto campo de estudo. Não foi possível ver na pena de prisão qualquer problema, afinal era a punição igualitária, por isso o diferente, o equivocado, o doente só podia ser o delinquente. A prisão 
podia ser reformada, não como pena em si, mas para que se acrescentasse algo a mais: o tratamento.

\subsubsection{Antropologia Criminal: Cesare Lombroso}

Em uma rápida busca pela internet vamos encontrar dezenas, senão mais de uma centena, de referências em artigos, livros e teses, à Cesare Lombroso como o pai da criminologia $^{26}$, título que lhe é atribuído em todo o lugar do mundo (HAGAN, 2011; GABBIDON, 2010; FERNANDES; FERNANDES, 1995; THOMPSON, 1998; MAYRINK, 1982). Contudo há quem atribua a paternidade da criminologia a Beccaria (HAGGERTY, 2001; SWANEPOEL; SAFFY; ZIETSMAN, 2008).

Impressionante como se atribuem pais às ciências. Sob a proteção de um pai fica mais fácil cometer equívocos. O pai está aí mesmo para amparar. Freud, paradoxalmente considerado o pai da psicanálise, falando da religião, explicou bem que o indivíduo, destinado a permanecer uma criança para sempre, anseia por um pai que o proteja, com poderes superiores, das consequências de sua debilidade humana (1980). Assim a criminologia ganhou um pai, um exemplo e uma proteção, que lhe permitiu e ainda permite vários erros, porque ele mesmo, o pai, simboliza o equívoco.

Desnecessário reconstruir a teoria lombrosiana do criminoso nato, desenvolvida na obra que selou a sua paternidade da criminologia, publicada pela primeira vez em 1876. Em $O$ homem delinqüente (2001), ele defendia que certos tipos de criminosos eram atavicamente predispostos à prática delituosa, pensamento acerca do qual não há quem não tenha ouvido falar, vez que há o verbete lombrosiano nos nossos dicionários, inclusive no Dicionário Brasileiro de Insultos (ARANHA, 2002). Portanto, Lombroso acabou sendo pai também de outro símbolo, desta vez relacionado ao preconceito e à estigmatização.

Inviável defender a teoria de Lombroso, médico e professor italiano de respeito em sua época, mas pode-se tentar entender o erro do ser humano Lombroso. Sim, o pai também é humano, e Lombroso acreditava, movido pelo entusiasmo do renascimento de uma Itália recém unificada, movimento no qual ele teve participação efetiva, pela força do positivismo

\footnotetext{
${ }^{26}$ Apesar de Lombroso não ter se intitulado criminólogo, mas sim da escola antropológica italiana (SHECAIRA, 2008).
} 
que crescia em todos os ramos científicos, que podia criar uma teoria sobre o crime nos moldes do evolucionismo darwiniano. Aliás, o grande mérito atribuído a Lombroso foi o de ter superado a análise metafísica do crime e, embora ainda que erroneamente, ter procurado explicações em fatos e provas materialmente verificáveis (DIAS; ANDRADE, 1997), derivando daí o nome escola positivista.

Ao mesmo tempo, no século XIX, eram poucos os que tinham estudo e poderiam contestar Lombroso, enquanto muitos necessitavam de um sistema geral de crenças que se convertesse em substituto da religião tradicional e desse respostas para questões inexplicáveis. O capitalismo surgia baseado no livre mercado, sem o poder despótico do rei, e uma ciência de controle de massas era bem vinda, "o método científico adotado para o estudo da sociedade seria uma alternativa apolítica para abordar os problemas sociais como objetos neutros governados por leis universalmente válidas" (OLMO, 1999, p. 24$)^{27}$.

A situação era propícia para um homem que colocava o seu instinto científico acima da própria racionalidade e substituía a meditação lógica pelo improviso, perseguindo seus objetivos obstinadamente em prejuízo à própria verdade, notadamente quando se via contestado e, na Academia, não foram raras as contestações (MAZZARELLO, 1998).

Tendo sido o crime uma doença para Lombroso, o tratamento não poderia ser a pena de prisão reeducativa, mas sim algum remédio que a ciência ainda não conhecia. Enquanto isso, a indicação não era de cárcere, mas sim de medições de crânio, de orelhas, de narizes, pesagens, estatísticas, e quanto mais fosse necessário para separar, classificar e excluir os que eram irrecuperáveis.

Foi Lombroso mesmo quem disse: “não é, por certo, o sistema penitenciário que previne as reincidências; as prisões são, ao contrário, sua causa principal” (2001, p. 403). A despeito da correção da sentença, o médico italiano não estava se referindo ao efeito

\footnotetext{
${ }^{27}$ Texto original: "el método científico adoptado para el estúdio de la sociedad sería uma alternativa apolítica para abordar los problemas sociales como objetos neutrales gobernados por leyes universalmente válidas". Rosa del Olmo, mais adiante, citando Franz Hinkelammert, completa que a ordem capitalista é baseada no conceito de que todos indivíduos gozam de liberdades iguais no seio da sociedade e "'el individuo que rechaza el orden social es un individuo que rehúsa ser libre y por lo tanto es perverso. La perversión puede tener distintas causas, pero da derecho a obligar al individuo a ser libre y en caso de rebeldia a tratarlo como uma alimaña'. Con esta concepción se justificaba el castigo más severo para el que no quisiera ser libre; pero habría que determinar qué significaba 'ser libre' en ese momento" (1999, p. 29)
} 
criminógeno da prisão, descoberto anteriormente por Howard, mas sim ao fato de que muitos criminosos reincidiam porque queriam passar um tempo na prisão para restabelecer a saúde ou para rever os companheiros, retornando de forma gloriosa.

Lombroso não percebeu que o que ele pretendia fazer era uma ciência humana e que, como tal, "apresenta um conhecimento parcial, fragmentado, provisório" (SHECAIRA,2008, p. 42). Ele pesquisou criminosos na prisão, já destruídos pelo próprio cárcere, que mantém uma postura defensiva, quando não irônica ou dissimulada, como forma de proteção contra aquele que vem examiná-lo. E mesmo que trabalhando com quem vivia em liberdade e a quem ele atribuía a qualidade de criminoso, é evidente que suas pesquisas continuavam prejudicadas pelo retraimento comum a qualquer pessoa contra aquele que vem etiquetá-lo.

Paolo Mazzarelo, citando Sighele, definiu bem as penas estabelecidas na teoria lombrosiana para os tipos de delinquentes encontrados:

Para Lombroso existiam os criminosos sem esperança de arrependimento. Tais eram os «delinquentes natos», a forma mais atávica de ser humano. Para confrontá-los a sociedade tem o direito de defender-se inclusive com a pena de morte, assim como o homem se defende dos animais ferozes sem que com isso «sinta culpa de não ter nascido cordeiro». Há igualmente os delinquentes que, por sua potencial periculosidade social, devem ser mantidos no cárcere ou no manicômio por toda a vida, independentemente do crime que tenham cometido. Entretanto há aqueles em que uma genérica predisposição e um fator ocasional no ambiente são desencadeadores de um evento criminal, os quais podem ser enviados para a reabilitação, por exemplo em uma colônia agrícola ou industrial ${ }^{28}(2005$, p. 24-25)

O texto acima é esclarecedor, fala de arrependimento, de defesa social, de reabilitação e até de colônia agrícola ou industrial, estabelecimento que a atual lei brasileira, embora descumprida, exige que tenha em todos os Estados (art. $35, \S 1^{\circ}$, do Código Penal). É um texto que praticamente resume a história da punição, desde o arrependimento exigido no início, com o acusado podendo ser morto ou purgando uma pena, passando pela defesa da sociedade como um ente estabelecido em contrato, até a reabilitação e os locais de punição que encontramos hoje. Para Lombroso, quanto mais evoluído fosse o homem, mais evoluída deveria ser a pena.

${ }^{28}$ Tradução livre do texto: "Per lombroso esistevano criminale senza speranza di resipiscenza. Tali erano i «delinquenti nati», le forme più ataviche di esseri umani. Nei loro confronti la cocietà aveva il diritto di difendersi anche con la pena di morte, cosi come l'uomo si difende dalle belve feroci senza com questo «credere che esse abbian colpa di non essere nate agnelli». Inoltre vi erano delinquente che, per la loro pericolosità sociale potencziale, dovevano essere tenuti in cárcere o nel manicômio per tutta la vita, independentemente dall'entità del crimini da loro commesso. Invece altri, nei quali una genérica predisposizione aveva trovato nell'ambiente l'occasionale fattore scatenante di un evento criminale, potevano essere avviati alla riabilitazione, per esempio in uma colônia agrícola o industriale" (BORINGHIERI, 2005, p. 24-25) 
Entretanto, bem se vê que não se pode atribuir a Lombroso um ideal ressocializador. Ele era um médico e como médico pensou em tratar o que achou ser uma enfermidade.

Alguns podem ver nas teses de Lombroso o germe do que se convencionou chamar tratamento penitenciário, mas ao que tudo indica essa ideia de tratamento nasceu da mesma forma que a prisão, aos poucos, fazendo parte do próprio sentimento de quem trabalhava com o cárcere. Depois falaremos com mais minúcias (2.1.6), contudo, no momento em que Lombroso escrevia a sua tese, nos Estados Unidos da América, eram criados os primeiros sistemas penitenciários, cada um com uma regra que, cruel ou não, demonstrava o empirismo em que foi forjada a nossa prática penitenciária.

De Lombroso podemos tirar uma lição para o tema deste trabalho: a cegueira que pode afetar a pessoa que trata um assunto relacionado às relações sociais, nas quais se inclui o crime, pode levar a consequências seríssimas. Não interessa de onde é derivada essa cegueira, se do preconceito, da limitação histórica ou social do pseudocientista.

Lombroso possui uma biografia interessante e seus biógrafos afirmam ter sido ele uma pessoa humana e amiga dos pobres, mas também teimosa e perseverante (MAZZARELLO, 1998), o que o fez colocar uma máscara sobre os seus sentimentos em nome da ciência que ele pensava estar criando para ajudar a socieade. Pelo que se extrai de suas biografias, Lombroso não percebeu que sua prática poderia conduzir, ao contrário, à estigmatização e até ao genocídio $^{29}$. Igualmente Bentham não imaginou até onde o utilitarismo levado ao exagero poderia chegar.

Lombroso foi seguido, tem seguidores até hoje, mas uma das formas de apagar os rastros dos que o seguem foi destruir a sua imagem e seu significado, foi ridicularizá-lo, fazer parecer que Lombroso era um completo idiota. Sua obra foi banida da Academia como uma heresia na Idade Média. Ainda assim há que se citar dois trechos do livro proibido, O homem delinquente:

Eu direi mais: a complacência que encontramos no público, mesmo pela condenação de um alienado culpado de um ato de selvageria, etc, é um resto do antigo sentimento

\footnotetext{
${ }^{29}$ Quando as doutrinas antissemitas começaram a se difundir na Europa, a partir de 1880, Lombroso, que era judeu de nascença, se viu obrigado a refutá-las alegando que o antissemitismo sim era uma forma de degeneração. Todavia, o criativo recurso não convenceu os partidos políticos que criavam raízes na França, Alemanha e Áustria (HEMAN, 1998).
} 
de vingança que, a seu turno, como veremos adiante, é a fonte da maior parte dos delitos, porque persiste em maior proporção no criminoso nato. A oposição encarniçada que encontra a nova escola antropológica criminal que, olhando os culpados como doentes, quer, por isso mesmo, lhes aplicar a detenção perpétua, provém, sem qualquer dúvida, de um sentimento que se guarda e esconde, por assim dizer, em qualquer um de nós, mesmo entre os que a defendem com maior energia. Não se vê na detenção uma simples satisfação conveniente. Vemos compensação feroz de ver sofrer aquele que fez sofrer, quer-se o talião - mas somente por pudor muda-se seu nome e aparência (2001, p. 123)

O que Lombroso fala sobre a vingança é essencial. Sendo correta a hipótese de que ele não estava mal intencionado quando escreveu seu trabalho, e não se encontram dados em sua biografia que levem a essa conclusão, Lombroso confessou o verdadeiro motor do seu e de muitos outros posicionamentos atuais que não conseguem perceber o ser humano praticante de um delito como um ser humano que simplesmente errou, e não pode ser tratado como um animal enjaulado: o sentimento de vingança.

Passagem rápida de $O$ homem delinquente, essa referência à vingança não significa que Lombroso fosse favorável a que a pena servisse como vingança. Ele traduziu um sentimento, atávico e superável na sua concepção, em uma sinceridade científica que permitiu que os sentimentos escondidos por detrás da pureza teórica ficassem aparentes.

Nesta concepção, o dia a dia do sistema penal, com prisões superlotadas, pessoas há mais de um ano sob prisão provisória, funcionários, advogados, promotores e juízes incessíveis à exclusão e à seletividade que é o sistema, tudo é mantido pelo mesmo sentimento. Um sentimento que quando é encontrado no criminoso é transformado em agravante da pena, bem aos moldes do que Lombroso queria, mas no profissional do direito deve ser velado. A ciência direito serve como subterfúgio para encobrir o exercício desse sentimento tão humano, mas que, diferentemente do que fez Lombroso, não tem feito parte de nenhuma reflexão.

Winnicott, falando mais de cinquenta anos depois, em 1967, explica o quanto as autoridades encobrem esse sentimento fazendo transparecer que a preocupação principal no ato de punir é com a segurança, deixando de revelar um "reservatório de vingança incosciente" (2005-b, p. 231), que não pode ser revelado e que se tornou bastante impopular, a ponto de ser proibido falar dele. 
Muitos viram vantagens no frio utilitarismo de Bentham, o qual serviu para inumeráveis legislações, mas poucos perceberam a sua máquina de chicotear, que dizia muito de seus sentimentos inconfessáveis. Assim é nossa prática no judiciário, uma inconfessável máquina de injustiças.

E segue Lombroso em outra reflexão semelhante a essa:

Para finalizar, direi que a origem impura da justiça pode servir para nos explicar a desigualdade com que ela se distribui, de povos a povos, e, coisa pior, de classes a classes. Sabe-se que, enquanto o parquet em sua cadeira declama a justiça eterna, igual para todos, o pobre não obtém realmente justiça, senão por exceção e como que por caridade. $\mathrm{O}$ rico, ao contrário, dispõe de meios numerosos para escapar, ou ao menos para obter um castigo mais suave (2001, p.123)

Assim o professor de Verona termina um de seus capítulos, sem perceber que sua teoria poderia estar infectada pelo preconceito temido por ele próprio, mas expressando uma verdade inconteste, a de que a justiça é feita com ares de ciência e acaba encobrindo ou reforçando as desigualdades que deveria evitar.

Se for dos erros que tiramos grandes lições, o esquecido e enigmático Lombroso não deveria ser evitado. Além de nas reedições de sua obra constar referências aos seus opositores e a argumentos que combatiam a sua teoria, o contexto em que foi escrito $O$ homem delinquente, de uma Itália unificada sem consenso, com o povo do sul insatisfeito, é questão a ser estudada. O descontentamento meridionale fez com que Lombroso, ciente ou não, fosse encontrar naquele povo as características do homem violento, tachando-o como criminoso, servindo sua teoria como um útil instrumento de controle político social.

A ciência destituída da visão de seu próprio momento histórico, econômico e social, acaba como instrumento político. Ruy Barbosa chegou "a apontar os compromissos políticos de Lombroso, mostrando que em todos os anarquistas italianos ele diagnosticava a 'tara hereditária"” (RAUTER, 2003, p. 33). Todavia, esses compromissos tornam-se mais fortes na medida em que a inconsciência deles mesmos faz com que a ciência ganhe a aparência de neutralidade.

\subsubsection{Sociologia criminal: Enrico Ferri}

Enrico Ferri, genro de Lombroso, é considerado "sucessor e continuador do pensamento de seu sogro" e "foi um dos mais importantes pensadores do seu tempo" 
(SHECAIRA, p. 104). Apesar de inspirado no médico italiano, Ferri era sociólogo e seu trabalho na criminologia seguiu no sentido de buscar fatores e causas do crime no ambiente e também na história individual do criminoso. No campo do Direito Penal trabalhou em inúmeras reformas legislativas.

O ambiente favoreceria a prática criminosa, mas sempre somado a fatores antropológicos e físicos. Dependendo da situação um ou outro seria preponderante, mas sempre estariam em conjunto conduzindo ao crime. Para Ferri, como uma doença é sempre causada por condições orgânicas somadas a fatores do ambiente, como frio, calor, sol ou vento, o crime também era um fenômeno derivado de diversos fatores ${ }^{30}$.

O conceito de reeducação social estava fortemente presente em Ferri, em razão de sua concepção de que a função do Direito Penal era a de defesa social. Portanto uma reeducação para combater o crime e não uma medida em prol do condenado. Quando observamos os assuntos tratados por ele na sua última obra, de 1928, percebemos a intensidade de sua influência no pensamento penal atual, pois ele aborda questões como individualização da pena, a interdisciplinaridade da equipe individualizadora, verificação de periculosidade e cessação desta e a classificação e separação de presos (1999), isso para ficar só nas questões relacionadas à pena.

Criou várias classificações para os criminosos e defendia que a pena fosse aplicada com base nessas diferenciações, ou seja, com base no grau do que ele considerava a periculosidade de cada um. Embora o seu projeto para o Código Penal italiano de 1921 não tenha sido levado à frente, em razão do regime fascista que se instalou na Itália, algumas de suas propostas foram adotadas pelo legislador de 1930, entre elas o sistema do duplo binário

\footnotetext{
${ }^{30}$ Enrico Ferri esteve no Brasil, e ao retornar à Itália, teria se posicionado relativizando o seu pensamento a respeito da influência do ambiente na prática do crime em discurso pronunciado na Câmara dos deputados, em Roma, em 22 de junho de 1909: "Tive que modificar também, um pouco, meus conceitos científicos a respeito dos caracteres étnicos dos italianos, vendo-os trabalhar naquele ambiente. Na civilização contemporânea as duas grandes raças, latina e anglo-saxônica, com suas derivações alemã, norte-americana e australiana, possuem estes caracteres fundamentalmente diferentes: nos latinos predomina o intelecto e a fantasia, enquanto nos anlgosaxões predomina a energia da vontade. Mas no Brasil eu vi os italianos acrescentar à admirável potência de seu talento natural uma força de vontade metódica, que não constitui a expressão de um caráter de raça imutável e fatal, mas apresenta em grande parte o fruto do ambiente em que esta nobre raça latina se encontra, desenvolvendo sua luta para uma existência melhor em condições diferentes das que correspondem à sua civilização histórica" (CENNI, 2003, p. 223).
} 
que permitia a aplicação da pena em conjunto com a medida de segurança (CIAPPI; COLUCCIA, 1997).

Com efeito, pode-se encontrar algum indício, enfim, no início do século passado, das raízes de um projeto que se entende por ressocializador, como atualmente se concebe esta palavra. Não obstante, é importante lembrar que Ferri entendia por indispensável uma estrutura técnica eficiente para tanto. Ele entendia impossível o seu projeto reabilitativo mediante uma justiça burocratizada, e defendia a especialização de juízes, funcionários, da polícia judiciária, dos advogados, ou seja, de todos os atores do processo penal. Portanto, somando-se ao fato que Ferri falava como reformador de legislação, o seu projeto e seus textos nada mais eram do que um esquema traçado mentalmente para o sistema penal: um verdadeiro projeto.

Ferri não colocou na balança a realidade do sistema prisional, pensou em reformá-lo somente. Buscando combater a concepção da Escola Clássica que tinha como parâmetro o crime e o princípio da legalidade, tentou incluir o conceito de periculosidade do criminoso, com evidente influência de Lombroso, na dogmática penal. Em outras palavras, Ferri almejava substituir o Direito Penal do fato pelo Direito Penal do autor. Por isso, para ele era indiferente se o fato crime preenchia ou não todas as circunstâncias para ser considerado um ilícito penal, bastava que diante das circunstâncias a pessoa demonstrasse que era perigosa para merecer punição. Para Ferri o crime impossível, por exemplo, não era um fato com ausência de elemento típico, mas um indício de periculosidade que indicava a necessidade de reprimenda (1999).

A denominação de Escola Clássica, para englobar todos os pensadores iluministas que elaboravam e estabeleciam garantias civis, foi uma criação de Ferri. O que ele pretendeu, nos termos da crítica áspera de Zaffaroni e Batista, foi, comodamente, "impor um rótulo comum a todos os penalistas que não compartilhavam seus pontos de vista. Essa invenção não passou de uma atitude autoritária de quem considerava ser o único dono da verdade” (2006, p. 576) (itálico no original).

Embora pudesse parecer que Ferri tentava superar uma concepção abstrata do crime para trazer à consideração a figura do criminoso, o que ele fez, na verdade, foi incluir a figura 
do criminoso como ente abstrato no Direito Penal. Um ente construído por ele, com suas classificações arbitrariamente estabelecidas, merecedor de uma correção imposta em nome da defesa social.

O sociólogo italiano acreditava na reforma da realidade social por intermédio da legislação, não só corrigindo o infrator, mas modificando todo ambiente da sociedade que propicia a ocorrência do que ele denominava como praga, o crime (FERRI, 2007), sendo evidente, mais uma vez, a influência do período histórico que favorecia a crença em uma ciência todo poderosa superior às subjetividades e individualidades do ser humano.

Quanto ao réu, a ideia de lei perfeita era tanta que Ferri confundiu comportamento com personalidade, "uma especulação a nível individual entre o que se faz e o que se é"31 (CIAPPI; COLUCCIA, 1997, p. 65), como se o comportamento previsto pela lei fosse suficiente para estabelecer a personalidade desviada que mereceria punição e reforma.

A punição seria de uma extrema gravidade - porque Ferri era a favor da pena indeterminada - alcançando o seu fim somente quando comprovada a cessação de periculosidade. Porque se o crime era comprovação de um mal biológico, o criminoso só poderia ser solto quando comprovada a sua adaptação ao meio social. Posicionamento que, como os outros, colocava sempre o Estado em primeiro lugar.

Ele acreditava que a jurisdicionalização da execução penal poderia trazer critérios justos para a cessação de periculosidade e concessão do livramento condicional, e que a participação do juiz evitaria decisões injustas por parte do diretor do estabelecimento carcerário, tudo sempre acompanhado por médicos que atestariam o fim do estado periculoso do preso:

"É fácil ver, pelo contrário, que na organização penitenciária como, por exemplo o nosso Projeto de C.P. estabeleceu nas suas linhas sumárias, não existirá o 'arbítrio' do diretor. Em cada cárcere, deve existir um Conselho de vigilância, composto pelo Diretor, pelo Médico antropólogo-criminalista, pelo Professor, pelo Capelão, por um mestre de obras e também por um condenado (da classe dos ótimos) (...) Fica, portanto, excluída a possibilidade de injustiça ou de favoritismo e são, pelo contrário, garantidos assim tanto o direito individual do condenado como o da sociedade, que não receberá, como até agora, todos os dias a volta de elementos inadaptados e mesmo irredutíveis a uma vida normal (FERRI, 1999, p. 350) (Grifo no original).

\footnotetext{
${ }^{31}$ No texto original: "una speculare riflessione a livello individuale tra ciò che se fa e ciò che si è" (CIAPPI; COLUCCIA, 1997, p. 65).
} 
Como se vê, uma estrutura muito semelhante à atual Lei de Execução Penal brasileira, o que além de demonstrar o pioneirismo de Ferri, e sua influência quase cem anos depois, comprova que a sua teoria não era baseada em dados empíricos, mas simplesmente uma estrutura legislativa que pensava ele poder alterar a situação do sistema carcerário e do sistema penal como um todo.

A incompatibilidade do pensamento de Ferri com o mundo atual é óbvia. Sua teoria dependia de um Estado forte, com mão de ferro, pois baseada na soberania absoluta de um ente estatal materialmente considerado, o qual seria a vítima dos crimes e poderia intervir na vida dos cidadãos livres, presos, condenados ou não, para fazer valer sua função de defesa social, ou seja, de defesa dele mesmo. Ou pior, o criminoso, seria um verdadeiro inimigo do Estado, e nessa condição permaneceria enquanto o Estado não o declarasse em paz. Portanto, em um Estado Democrático de Direito, não há como sustentar tal procedimento, que exclui qualquer garantia do ser humano. Também não é difícil perceber que a visão de um Estado desse tipo, naquele momento histórico, foi a causa de tanto sofrimento e morte que todos conhecemos.

E a ideia que Ferri teve de reabilitação não passou de ideia, não só porque ele estava equivocado, ele mesmo não acreditava na recuperação projetada legislativamente, mas igualmente porque nunca houve condições para que pudesse por em prática sua especulação científica. Se o ressocializar presente nos discursos hoje em dia tem alguma coisa a ver com o essa reabilitação da escola positivista não pode ser a crença, já que tantos anos se passaram, mas só a ideia de um Estado arbitrário.

\subsubsection{Raffaele Garofalo e o crime natural}

O terceiro grande nome da Escola Positivista foi Raffaele Garofalo, o qual fez sua carreira como advogado, promotor, juiz, professor de direito, tendo sido membro do governo italiano. Sua principal obra é Criminologia, de 1885. Em razão de sua formação jurídica, Garofalo seguiu as ideias de Lombroso mais particularmente interessado na definição legal de crime e nas sanções apropriadas, tendo criado a figura do crime natural. Deu ênfase maior às deficiências psicológicas do criminoso do que às anomalias físicas. Ele defendia que os 
criminosos possuíam deficiências de sentimentos relacionados à moral e, por isso, não tinham medo da punição, perdendo o autocontrole (BURFEIND; BARTUSCH, 2011).

Como Ferri, o sistema racional de penalidade de Garofalo (1997) era um voto de confiança na legislação para alterar a realidade. No fundo, a preocupação de ambos com a prevenção do crime, ainda que nisto se incluísse certa dose de recuperação do criminoso, tinha um forte caráter de sentimento dissuasório, como sempre foi a pena na história da humanidade. A recuperação, mesmo o tratamento e seu programa como referido há pouco na abstração legal de Ferri, tinha o sentido de força, para que a dor fosse predominante na mudança de comportamento do criminoso.

Neste ponto a dúvida não é possível. Conquanto não aterre todos os criminosos, o
patíbulo põe medo a um grande número deles, que seriam insensíveis à ameaça de
uma reclusão mais ou menos prolongada. Ele exerce influência em todo o campo da
criminalidade, como anteriormente mostramos, porque o homem disposto ao crime
não sabe exatamente qual a pena que lhe será aplicada e receia sempre incorrer na
capital, quando sabe não que ela existe na lei do país, mas que se executa
(GAROFALO, 1997, p. 293)

Este acima era o tratamento previsto para os assassinos, malfeitores privados do senso moral, para os quais não haveria outra saída que não fosse a morte. O cárcere, nestes casos, seria um desperdício de dinheiro por parte do Estado ${ }^{32}$.

A prisão, Garofolo reservava somente para os criminosos violentos ou impulsivos, contanto que fosse em numa ilha, colônia ou aldeia remota (1997), evitando-se qualquer possibilidade de retorno ao convívio social. E a conclusão que se tira de suas próprias palavras é a de que sua visão de pena não passava do que Lombroso bem advertiu, pura e simples vingança, o talião. Porque o único critério adotado por Garofalo para aplicar uma pena mais grave ou não é a maldade do criminoso.

Quando Garofalo se preocupa com o tempo que o criminoso passaria nessa ilha, volta a demonstrar a confiança presente em todos os positivistas no sistema: "deve-se acrescentar a doçura de caráter manifestada pelo condenado de um modo constante e seguro, e não apreciada pelos falsos critérios das direções penitenciárias” (1997, p. 296); embora logo

\footnotetext{
${ }^{32}$ Enrico Ferri, neste ponto divergia de Garofalo, pois entendia que a quantidade de homicídios qualificados, crime para o qual ele achava cabível a pena de morte, era tanta na Itália que seria praticamente inviável cometer "uma carnificina permanente de seis ou sete execuções capitais por cada dia do ano". No original: "una carnificina permanente di sei o sette esecuzioni capitali per ogni giiono dell'ano" (1885, p. 56).
} 
adiante confesse acentuada fragilidade na sua ideia de controle do comportamento: "na prática, um certo empirismo seria inevitável pela necessidade de estabelecer um período de observação" (Idem, p. 298).

Bem se vê que a situação penitenciária italiana, como sempre, era péssima, pois nenhum dos positivistas demonstra depositar qualquer voto de credibilidade nas administrações penitenciárias. Mas o que mais se demonstra estranho é que a crença de todos no sistema, em uma legislação que resolvesse o problema da criminalidade, passava por órgãos públicos bem treinados e confiáveis, virtudes que eles nunca admitiam poder haver na administração penitenciária, como se esta também não fizesse parte do sistema prisional.

Garofalo admitia punir as crianças, quando estas demonstrassem "tendência instintiva e invencível ao sangue" (Idem, p. 299), mesmo que na primeira infância, sem indicar data precisa como limite para a sanção e novamente confiando às autoridades a definição da indispensabilidade da pena.

Salvo melhor juízo, o crédito de Garofalo na atuação da magistratura é tão grande que o seu sistema demonstra inúmeras incongruências, deixando que várias circunstanciais sejam verificadas por ocasião do fato. Sua elaboração é por demais abstrata, o que nos leva a concluir ser absolutamente contrária ao princípio da legalidade, não só antes da condenação (aliás, os positivistas não reconheciam valor no princípio da presunção de inocência), mas sobretudo na execução penal.

A obscuridade é tanta no sistema que fica difícil imaginar a sua operacionalidade. Para Garofalo, tendo adotado a concepção de crime natural, o fato só seria crime se o criminoso demonstrasse maldade para ser classificado como tal, colocando o juízo de maldade ao arbítrio do julgador. No caso, "a apelação inquestionavelmente irracional aos sentimentos faz Garofalo cair no etnocentrismo, isto é, na consideração da própria cultura como a 'cultura superior'" (ZAFFARONI; PIERANGELI, 1997, p 303).

Como bem resume Shecaira (2008), a escola positivista tem como característica comum substituir a responsabilidade penal pela responsabilidade social, esta que é avaliada de 
acordo com o nível de periculosidade ${ }^{33}$. A pena, portanto, sempre é uma medida de defesa social e o criminoso sempre um anormal, momentânea ou permanentemente.

\subsubsection{Os primeiros sistemas penitenciários}

Se é certo que o sistema penal ocidental, aí incluídas todas as ciências e métodos que formam o que se convencionou chamar sistema penitenciário, sofreu influência mais decisiva desses reformadores ingleses e italianos do que de qualquer outra fonte, fica fácil perceber que entre o início do que Ferri denominou de escola clássica e o início da escola positivista, transcorreram cem anos.

Não obstante ter sido um período de evolução das ideias iluministas, em que foram reforçadas garantias contra o arbítrio do Estado, desenvolvendo-se uma vasta doutrina sobre o crime e sua conceituação, a prática punitiva real, a prisão, continuou abandonada.

A construção dogmática se limitou às garantias da pessoa antes do julgamento. Diversos debates se travaram, teorias foram construídas e conceitos são discutidos até hoje sobre o crime e os limites da imputação por parte do Estado, mas a dogmática encerra após a condenação. Com o perdão de todos os autores que tentam construir uma base dogmática de garantias para o condenado, o debate jurídico científico na execução da pena ainda hoje é fraquíssimo, senão inexistente.

Voltaremos sobre esse assunto adiante. Importante agora, contudo, é a constatação de que apesar de não ter havido debate relevante sobre a prática punitiva, sobre a execução penal, durante muito tempo, as prisões continuaram funcionando. A prisão continuou ganhando espaço no arsenal punitivo do Estado. Por isso que este tópico trata das práticas punitivas nos Estados Unidos, vez que neste país, enquanto a Europa discutia a concepção de crime, algumas experiências com a prisão foram praticadas e serviram de exemplo e lição para o mundo todo. Há quem diga até "que a prisão é um invento norte-americano" (Norval Morris apud BITENCOURT, 1993, p. 59).

\footnotetext{
${ }^{33} \mathrm{Na}$ monografia Di un critério positivo della penalitá, Garofalo defendeu que a pena deveria ser aplicada na medida da temibilidade do criminoso, nomenclatura que depois foi substituída por Ferri para periculosidade, justificando e citando Rocco, que "a temibilidade de um indivíduo é antes a conseqüência do que é a sua periculosidade" (FERRI, 1999, p. 271).
} 
Alexis Tocqueville e Gustave de Beaumont, magistrados franceses, visitaram os Estados Unidos em 1831, portanto muito antes de a escola positivista pensar em usar o sistema penitenciário como forma de tratamento, para estudar e escrever sobre os costumes e instituições norte-americanas. O trabalho mais conhecido é a análise da forma de governo, publicada com o nome Democracy in America, mas, para o direito penal, ganhou bastante relevo o trabalho de avaliação do sistema penitenciário norte-americano que levou o título de On the Penitenciary Sistem of the United States, and Its Application in France; With an Appendix on Penal Colonies, and Also, Statistical Notes (ROTH, 2006) ${ }^{34}$.

$\mathrm{O}$ que os viajantes encontraram foi um verdadeiro laboratório de sistemas penitenciários. Seja no que se refere à disciplina, trabalho, saúde, instrução ou arquitetura penitenciária, havia nos Estados Unidos vários experimentos que faziam dos presos verdadeiros objetos. Só como exemplo, em uma penitenciária os presos se alimentavam em conjunto no mesmo pavilhão, mas em total silêncio; em outra, os presos tinham que comer em silêncio e separados, cada um em sua cela; algumas impunham silêncio e isolamento somente de noite; em algumas outras os presos podiam se exercitar em uma área comum; contudo, outras diferentes permitiam que os presos se exercitassem somente sozinhos, em um local definido. Com relação ao trabalho, em alguns locais era permitido o trabalho em conjunto, desde que em silêncio absoluto, mas em outros somente havia trabalho no interior da cela de isolamento (WOLIN, 2001).

Mas, no geral, a impressão dos magistrados foi ótima. Diferentemente do que eles disseram sobre a democracia nos Estados Unidos, na obra acima referida, onde defenderam que os direitos dos indivíduos deveriam ser protegidos da vontade do Estado, com relação ao sistema penitenciário o rigor era necessário para proteger a maioria respeitadora das leis contra a minoria de criminosos que existem na socieade. A impressão foi tão boa que depois Tocqueville, em uma carta de 1836, narrou desta forma o conceito que ele tinha do que deveria ser uma ciência das prisões:

Isolar os prisioneiros, separá-los e mantê-los em celas solitárias durante a noite, submetê-los ao mais absoluto silêncio durante o dia, quando eles são forçados a

\footnotetext{
${ }^{34}$ Roth, citando Norman Johnston, informa que teria sido Beaumont quem escreveu a maior parte do livro (2006). Na capa da edição fac-símile da Universidade de Toronto, consta igualmente apenas Gustave de Beaumont como autor (2012).
} 
estarem juntos; em uma palavra, proibir toda a comunicação entre espíritos e mentes, assim como entre corpos: isso é o que eu consideraria o primeiro princípio da ciência [das prisões] ${ }^{35}$ (Apud WOLIN, 2001, p. 385).

Os magistrados eram considerados humanistas ${ }^{36}$, mas tinham em mente as prisões abandonadas da Europa, por isso que o zelo e a disciplina rígida dos cárceres norte-americanos visitados tanto impressionaram. Aliás, o elogio ao sistema norte-americano poderia derivar da irritação, incredulidade e até saturação, relacionados ao sistema prisional francês. Contudo, Tocqueville e Beaumont se confundiram, porque a reforma moral dos presos não era o interesse principal daquele sistema, a preocupação maior era com a disciplina e o trabalho que os presos realizavam, era o que se conseguia para o momento, "os presos eram apenas excluídos por algum tempo do convívio social, somente isso" 37 (PIERSON, 1996, p. 702).

Ou talvez não tenham se confundido, mas orientado suas descobertas para fundamentar a própria crença no ideal de reforma do ser humano, tanto que chegaram a fazer concessão ao uso do chicote, "necessário para estabelecer o silêncio na recém fundada prisão",38 (BEAUMONT, 2012, p. 45), utilizado, segundo suas palavras, raramente.

As prisões que mais chamaram a atenção dos viajantes estavam na Filadélfia e em Nova York. O que ficou sendo conhecido como sistema filadélfico ou pensilvânico tinha isolamento total durante vinte e quatro horas e foi aplicado pela primeira vez na prisão de Walnut Street Jail, construída em 1776. O idealizador do sistema, Benjamim Franklin, tinha importado algumas ideias de Howard e as somou a um rígido princípio religioso (AGUILERA, 1998).

Na prisão de Auburn, em Nova York, construída inicialmente para seguir o modelo da Filadélfia, criou-se o sistema auburniano, onde o isolamento era noturno e o trabalho diurno

\footnotetext{
${ }^{35}$ Tradução livre de: "Isolate the detainees in prison, separate them during the night by means of solitary cells, subject them to absolute silence during the day when they are forced to assemble; in a word, prohibit every communication between their bodies: that is what I would consider the first principle of the science [of prisons]" (WOLIN, 2001, p. 385).

${ }^{36}$ Sem esquecer a lembrança de José Damião Trindade, de que a concepção de direitos humanos sempre mudou no curso da história e foi objeto de certa vulgarização, a ponto de o próprio Hitler ironicamente ter se queixado no começo de sua carreira, quando preso pelo Tribunal Militar: "como podem os homens, primeiro, criam leis, pensam, depois que estas estão acima dos direitos humanos" (2002, p 13).

37 "we put them away for a certain time, that's all" (PIERSON, 1996, p. 702)

${ }^{38}$ No original: "Stripes are not so frequent as is believed; necessary, as they are, to estabilish silence in a newly founded prison" (BEAUMONT, 2012, p. 45).
} 
podia ser realizado em comum, mas em absoluto silêncio, em nome da emenda e reflexão (Idem, Ibidem).

Independente do sistema que se tire como modelo, não há dúvida de que todos nasceram de forma empírica, sem qualquer base científica. Assim, conquanto tenha sido necessário fazer referência ao relatório de Tocqueville e Beumont, os sistemas norteamericanos não comprovaram nenhuma eficiência a que se possa atribuir a crença no ideal ressocializador. Muito pelo contrário, logo, com o tempo, as sequelas desses sistemas foram surgindo e a sua verdadeira função, como dito acima, de exclusão, restou descoberta.

Mesmo na época, os sistemas não foram imunes a críticas. Von Hentig definiu o pensilvânico como uma tortura refinada que "desaparece aos olhos do mundo, mas continua sendo uma sevícia insuportável, embora ninguém toque no apenado. O repouso e a ordem são estados iniciais da desolação e da morte" (apud BITENCOURT, 1993, p. 63). Ferri qualificou o sistema celular norte-americano como aberração, pois não serviria para a emenda do condenado, debilita o seu senso moral e social e é ineficaz porque os presos podem encontrar vários meios para se comunicarem entre si, além do que é "demasiadamente caro para que possa se sustentar"39 (AGUILERA, 1998, p. 62).

Quando, na penitenciária de Auburn, fizeram uma experiência para adotar o sistema pensilvânico, antes da chegada de Tocqueville, recolheram alguns presos em isolamento completo, e a maioria apresentou rapidamente problemas psiquiátricos: um pulou do quarto andar, quando abriram a porta de sua cela, outro cortou as veias com um objeto pontiagudo, e um terceiro perdeu uma vista batendo com a cabeça na parede. Contudo, a própria disciplina de Auburn se foi deteriorando. Em 1910, o edifício já foi encontrado mal cuidado e escuro, não havia mais zelo com os uniformes dos presos, o apoio público às oficinas de trabalho não existia mais, denúncias de tortura ficaram conhecidas, enfim, o sistema disciplinar inicial tinha sido abandonado, apesar do discurso das autoridades não ter sido alterado (MCSHANE; WILLIAMS, 2005).

Mas não são os altos e baixos da administração penitenciária norte-americana que vêm ao caso, o fundamental é saber que a prática penitenciária dos Estados Unidos se constitui em

\footnotetext{
${ }^{39}$ No original: "demasiado costoso como para que pueda sostenerse" (AGUILERA, 1998, p. 62).
} 
uma experiência com seres humanos ${ }^{40}$. Digo melhor, a prática penitenciária mundial é uma experiência com seres humanos. O que depois passaram a chamar de penalogia, penology, tem nome de ciência, mas é um aglomerado de opiniões e testes com seres humanos.

É certo que uma ciência pode ser feita de experimentos, aliás, deve, mas normalmente esses experimentos precedem o objetivo final da prática científica. Outrossim, se o experimento não surtir efeito, deve-se desistir da prática. $O$ teste é justamente para comprovar uma hipótese e passar à prática. Em outras palavras: com a prisão se fez o oposto, primeiro começaram a prender e prender cada vez mais, depois começaram a fazer testes do que se convencionou chamar reabilitação, ressocialização, ou seja lá mais o que for, para fazer da prisão uma prática cientificamente justificável. Seria isso a penalogia?

Sem querer adiantar raciocínio, mas a ocasião é propícia. Se foram feitas tantas experiências com seres humanos presos, - inclusive de torturas, bem se sabe - pode-se explicar que aquelas pessoas presas eram recém escravos, algumas mendigos sem qualquer status de cidadão, as mulheres nem mesmo tinham direito a voto, então facilmente submetidas à condição de objeto da administração pública. Todavia, hoje não se admite mais tanta experiência, tanto descaso para com o ser humano, todos são sujeitos de direito, miseráveis ou não, e, se o experimento científico não deu certo, é hora de abandoná-lo.

Note-se que a crítica aqui, em tudo que foi e que será dito - é preciso esclarecer - não é direcionada a esta ou àquela pessoa. Todos esses reformadores tiveram importantes participações na história do Direito e na história do ser humano em geral. As críticas que foram feitas, assim foram somente no sentido de fazer ver que todas essas ideias partiram de seres humanos passíveis de erros, que tinham suas paixões não expressadas por trás de tudo que escreveram, sejam esses sentimentos oriundos da classe social a que pertenciam, do momento histórico, sejam derivados da simples sentimentalidade humana. O que não pode é o Direito pretender ser uma ciência exata e fazer de todas essas ideias conclusões matemáticas ou mandamento dos deuses, para, sem discutir, continuar com sua prática prisional irracional.

\footnotetext{
${ }^{40}$ Interessante saber que em 1907, Gina Lombroso publicou uma nova edição da obra de seu pai citando várias prisões e reformatórios onde as teorias de Lombroso estavam sendo aplicadas, todos nos Estados Unidos. Trinta anos depois, pouco antes da Segunda Guerra Mundial, o criminólogo Earnest Hooton, de Harvard, ainda usava os métodos de Lombroso para classificar os delinquentes (HERMAN, 1998). E na década de 40, vinte e sete dos quarenta e oito Estados norte-americanos adotavam medidas de castração de loucos ou delinquentes (SHECAIRA, 2008).
} 
Voltando aos sistemas penitenciários, ou a outras experimentações, não foram só os Estados Unidos que progrediam neste sentido. Na Austrália, por volta de 1840, na colônia penal de Norfolk, faziam-se as primeiras tentativas do que pode ser a origem da remição, como adotada na legislação brasileira. $\mathrm{Na}$ Irlanda o preso podia ter o rigor da sua pena atenuado de acordo com o comportamento até obter livramento final sob vigilância. Foi o que depois se denominou, com suas diversas variantes no mundo todo, de sistema progressivo (MUAKAD, 1996).

A distância no tempo em que nos encontramos desses diversos sistemas faz parecer que o ideal de ressocializar movia todos os reformadores, quando a experiência ensina que o motor político é sempre mais forte e usa a teoria como justificativa para suas ações. Quanto ao sistema irlandês, nos livros de direito de hoje pouco se diz sobre a situação daquele país na época do estabelecimento do sistema progressivo, mas naquela época já se observava que a mecânica da progressividade no cumprimento da pena se deu mais em razão do "número insuficiente de penitenciárias" (ARENAL,1895-b, p. 59) do que pelo ideal de ressocializar alguém.

$\mathrm{Na}$ literatura espanhola prepondera a tendência a se considerar como precursor do sistema progressivo, o sistema adotado no presídio de San Agustín, em Valência, dirigido pelo Coronel Manuel Montesinos y Molina desde 1834 (AGUILERA, 1998; ARTIACH, 2006). Neste sistema havia três períodos, o primeiro denominado "de ferros", o segundo "de trabalho em comum" e o terceiro "de liberdade intermediária"41 (AGUILERA, 1998, p. 85-86). Contudo, não é das especificidades de tais sistemas que pretendemos falar, mas da natureza empírica de seus idealizadores.

Por isso a referência ao presídio de Montesinos, porque o Coronel deixou para a posteridade um fato curioso que só reforça a imagem de experimento arbitrário em que se dava o encarceramento. Crítico dos demais sistemas penitenciários que surgiam no mundo, defendendo uma espécie de inclusão social pelo trabalho e pela disciplina, Montesinos resolveu fazer uma experiência para provar que o seu sistema era melhor que os demais. Então, criou um calabouço solitário e, surgindo sanções a serem aplicadas, "foi remetendo uma amostra de apenados, com a precaução de que fossem oriundos de um maior número de

41 "de hierros", "de trabajo en común" e "de libertad intermediaria" (AGUILERA, 1998, p. 85-86). 
regiões distintas da Espanha, para poder comprovar os resultados. Naturalmente o experimento resultou em um fracasso, constatando sua inaplicabilidade"42 (ALBACETE, 1999, p. 133). Um dos últimos a servirem de cobaia foi um preso das Astúrias (norte da Espanha) que em poucos dias foi levado à beira do suicídio. Embora não se saiba em que condições foram feitos tais experimentos, sabe-se que Montesinos queria provar que o isolamento absoluto era impraticável nos países meridionais, em razão de diferenças culturais, da maior liberdade do povo, do clima e por diversas outras circunstâncias (Idem, Ibidem).

Finalizando, nos Estados Unidos, aquele que foi tido por Tocqueville como o ideal, o de Auburn, menos severo com certeza, em 1929 ruiu completamente. Em uma rebelião que ficou marcada na história, vários presos destruíram quase por completo a penitenciária. Jogando ácido no rosto de um oficial, os internos conseguiram acesso ao arsenal que ficava localizado no edifício e colocaram fogo em quase tudo. Quatro presos fugiram. Seis alas destruídas. Dois presos morreram e um ficou gravemente ferido. Dois oficiais foram baleados, outro foi queimado por ácido e mais dois feridos (MCHUGH, 2010), mas as experiências continuam.

\subsubsection{Correcionalismo}

$\mathrm{Na}$ medida em que se assumiu a proposta de buscar nos diversos experimentos penais alguma prova a respeito de, se a ressocialização é ou não oriunda de uma constatação científica, este trabalho estaria incompleto sem uma referência à tida como escola correcionalista, desenvolvida na Espanha no Século XIX.

Como reivindicação, teoria ou proposta humanista, "as funções de ressocialização, reinserção social e melhora na execução das penas privativas de liberdade são muito mais antigas que a utilização do termo ressocialização" e o correcionalismo fez farta utilização de palavras como reeducação, correção e reabilitação, contudo "parece que o termo

\footnotetext{
42 "foi remetendo a él una muestra de penados, con la precaución de que fueran oriundos del mayor número de regiones distintas de España, para poder comparar los resultados. Naturalmente el experimento resulto un fracaso, constatando su inaplicabilidad" (ALBACETE, 1999, p. 133).
} 
ressocialização foi utilizado pela primeira vez no ano de $1932^{43}$ na Alemanha»44 (VIVANCOS, 2003, p. 13), do que se depreende ser a ressocialização uma palavra nascida em um acentuado contexto correcionalista positivista.

\subsubsection{Teoria Correcionalista}

Cezar Roberto Bitencourt nos explica que a "escola correcionalista" ter-se-ia iniciado "na Alemanha, em 1839, com a dissertação de Karl Röder, Comentatio na poena malum esse debeat", mas encontrado na Espanha "os seus principais seguidores, que cultuaram o famoso correcionalismo espanhol - de matriz eclético - destacando-se, dentre eles Giner de los Ríos, Alfredo Calderón, Concepción Arenal, Rafael Salillas e Pedro Dourado Montero" (BITENCOURT, 2009, p. 64).

O que pretendeu Röder foi criar uma, nas suas palavras, "teoría correccional” (1876, p. 32) e é bem evidente que seu trabalho visava academicamente combater as diversas teorias da pena em voga na época, e não elaborar uma teoria do que era verdadeiramente a pena. Pensava ele que convencendo legisladores e juízes sobre as finalidades da pena, a realidade desta seria alterada. Não entendemos como Bitencourt, para quem "o delinquente, para os correcionalistas, é um ser anormal, incapaz de uma vida jurídica livre" e que, "por isso, a sanção penal é vista como um bem" (2009, p. 65). As prisões, naquela época mais do que hoje, não permitiam que ninguém as considerasse um bem e, portanto, ao menos para Röder, não podiam ser consideradas um bem. Deviam ser um bem, porque o Estado não poderia praticar o mal, mas não eram. Portanto, a teoria correcional é mais uma tese reformista.

Também não encontramos na obra de Röder afirmação de ser o delinquente um anormal, incapaz de uma vida jurídica livre e, inclusive, na edição de 1876, o professor alemão faz referência a acusações semelhantes contra a sua teoria, partidas de C. F. Gabba, da Universidade de Pisa, tachando-as de “absurdas” (1876, p. 241). Ao revés, Röder dizia ser

\footnotetext{
${ }^{43}$ Seguindo a bibliografia trazida pelo autor, encontramos na obra de Mapelli, catedrático de direito penal da Universidade de Sevilla, que o termo ressocialização foi usado em 1923 para compor os "Princípios Fundamentales del Consejo del Reich" (1983, p. 200). Informação que coincide com a de Axel Hodapp, que em um breve histórico do conceito de ressocialização na Alemanha, indica que Gustav Radbruch, ministro da justiça alemão, aluno de Von Lizt, teria sido o primeiro a usar o termo "Resozialisierung" (2003, p. 18) na concepção que se tem hoje de educação e melhoria, junto ao parlamento imperial, em 1923.

${ }^{44}$ Tradução livre de: "Las funciones de resocialización, reinserción social y mejora en la ejecución de las penas privativas de liberdad son mucho más antiguas que la utilización del término resocialización [...] Parece que el término resocialización se utiliza por primera vez en el año 1923 en Alemania" (VIVANCOS, 2003, p. 13).
} 
muito "cômodo, todavia por demais injusto e ímpio, tratar qualquer um, mesmo o maior criminoso, como se de forma alguma já não fosse um homem, mas um 'animal selvagem', um monstro incorrigível”45 (Idem, p. 252). Ou seja, a própria ideia de correção do outro passava pela proposição de que o ser humano era responsável por seus atos, bastava tão somente direcioná-los para o bem, "influir eficazmente para sua humanização"46 (Idem, p. 251).

Para Röder, as teorias que admitiam a pena como sofrimento sustentavam os ainda remanescentes suplícios da Idade Média: as penas de galera e todas as inconsistências da prisão-depósito e o correcionalismo viria para, convencendo dever a pena buscar o bem, evitar praticasse o Estado o mal que vinha praticando, aceitando tais sanções. Dever-se-ia enobrecer o direito penal. Em suma, a ideia de correção do delinquente era um subterfúgio para se humanizar a prática punitiva de então.

O correcionalismo, a nosso ver, talvez pela nomenclatura recebida, talvez pelos fora de moda conceitos de moral e honra que ele tanto defendeu, é uma doutrina julgada de forma equivocada nos dias de hoje. Certo que o Estado Democrático de Direito não abre espaço para nenhum moralismo público, mas a verdadeira intenção dos correcionalistas nunca é posta em relevância: a humanização do sistema penal. Quando se classifica e se relacionam características comuns de uma teoria, muito se perde e o que se generaliza fica subordinado a um critério arbitrário.

A defesa do isolamento celular, a busca do arrependimento do criminoso, a ideia de tratamento, a busca da mudança do ser humano pela educação em situação de cárcere, a pena como um remédio para o mal do crime, são ideias que estão presentes até hoje e formaram a base do pensamento correcionalista. Assim, de todas as teorias do Século XIX, a correcionalista é a que mais se parece com os ideais de ressocialização presentes atualmente ${ }^{47}$.

\footnotetext{
${ }^{45}$ Tradução livre de: "cómodo, pero en el más alto grado injusto é ímpio, tratar á cualquiera, aun al mayor criminal, como si bajo ningum respecto fuese ya hombre, sino un 'animal selvaje', un mónstruo incorrigible" (RÖDER, 1876, p. 252)

46 "influir eficazmente para su humanizacion" (RÖDER, 1892, p. 251).

${ }^{47}$ Haroldo Caetano chega a sugerir uma sinonímia: "Ressocialização: sinônimo de correção" (2009, p. 52), e ele tem razão, pois o termo teoria correcional foi escolhido pelo tradutor (para o espanhol) da obra base do correcionalismo, mas outro poderia ter sido usado: "o nome alemão é Besserungstheorie, que pode traduzir-se por teoria da emenda, ou da reforma do criminoso. - Aqui traduzimos teoria correcional, porque o sentido técnico desta palavra em nosso direito positivo, ainda que limitado a certas penas, nulo e vazio (e até contraditório) na prática, diz fundamentalmente que a pena se considera como condição para o melhoramento do delinquente" (RIOS, 1876, p. 236).
} 
Todavia, quando se rechaça uma teoria antiga, deixa-se de examiná-la, abre-se espaço para recomeçar a almejar o mesmo fimm que antes não foi possível. E os argumentos se renovam em outras teorias, com nova etiqueta, tornando possível a realidade de um sistema penitenciário que pouco muda e também se reforça.

O que foi defendido de positivo, não só no correcionalismo, mas em muitas teorias até agora estudadas, é igualmente, propositalmente e convenientemente esquecido. Röder, por exemplo, defendeu a aplicação de multa para delitos leves, ou seja, não era a favor do encarceramento para muitos casos, combateu a prisão perpétua e a pena longa de prisão, "tendo em vista as contínuas reincidências que semelhantes penas trazem consigo"48 (1896, p. 247), mas hoje ainda continuamos na mesma batalha como se a travássemos com argumentos novos. Constatações como a de que o direito penal não poderá resolver todos os problemas sociais e de que as instituições de Estado devem ser integradas e colaborar entre si, estão na pauta do dia e estavam presentes em Röder.

E assim as coisas têm realmente o aspecto do simbolismo de Lola Aniyar de Castro, "a fome de confinar parece agigantar-se, e luta com denodo para encher as prisões. É uma Hidra de mil cabeças: se corta uma aparecem não duas, como no Segundo Trabalho de Hércules, mas cem" (2010, p. 92). Sempre há algum argumento em favor da pena de prisão que, como a própria sanção, é secular e já foi combatido, mas aparece como novidade reforçada pelo medo e circunstâncias modernas, como novas cabeças para a serpente.

A prisão ideal de Röder nunca foi conhecida por ele. Seria um estabelecimento penal em que cada preso teria a sua cela, limpa, clara e arejada, não haveria a regra de silêncio absoluto de Auburn, e o dia seria preenchido com a "simpatia de seus visitantes, cuja amistosa assistência e consolo interrompe beneficamente a solidão"49 (1876, p. 352), com livros instrutivos para os presos, práticas religiosas, ensino escolar e técnico. É no correcionalismo onde a metafísica do conceito de ressocialização se revela de forma mais cristalina ${ }^{50}$ e, reconhecemos, sincera. A história se encarregou em demonstrar a impossibilidade e o

\footnotetext{
${ }^{48}$ No original: "merced á las contínuas reincidencias que semejantes penas traen consigo" (RÖDER, 1876, p. 247).

${ }^{49}$ Tradução livre de: "simpatia de sus visitadores, cuya amistosa asistencia y consuelo interrompe benéficamente su soledad" (RÖDER, 1876, p. 352).

${ }^{50}$ Marx, em crítica às inúmeras teses e teorias nascidas na Alemanha em meados do século XIX, fala em "gritaria filosófica de feira livre" (2007, p. 86), todas dissociadas da realidade.
} 
desinteresse político pela proposta, mas a prisão sobrevive esperando seus reformadores. $\mathrm{O}$ correcionalismo foi enterrado junto com a constatação de seu erro, de que nenhuma reforma fará da prisão algo bom.

Outra lição importante que extraímos do correcionalismo é a de que a ideia de readaptação do criminoso é extremamente fértil e por isso os autores considerados correcionalistas não têm muitas propostas em comum. Por ser uma teoria, principalmente quando chegava o momento de apresentar sugestões concretas para a pena de prisão era a hora em que os autores mais divergiam e acabavam apenas se posicionando a favor ou contra este ou aquele sistema penitenciário, dentre eles os norteamericanos e o progressivo, dos quais já falamos e que se mostravam bem melhores do que as precárias prisões da Espanha e da Alemanha.

A ambiguidade do tema correção do outro comporta tantas ideias e variados sentimentos que mesmo o conceito de escola correcionalista é extremamente discutível. Inclusive o positivismo italiano, embora lentamente ${ }^{51}$ e por mais que não faça parte das especulações originais de Röder, compôs as teses de Rafael Salillas, considerado correcionalista, mas o principal representante de Lombroso na Espanha ${ }^{52}$.

O correcionalismo funcionava como uma espécie de política criminal e às vezes resumia-se em um discurso de política penitenciária, na qual a antropologia positivista encontrou amplo espaço de desenvolvimento. Mas Salillas não era um lombrosiano cego e fez as suas ressalvas: "Precisamente, a antropologia corre o perigo de se desvirtuar na própria origem, porque a ênfase que se tem dado ao pretendido anômalo constitui-se pouco a pouco em uma generalização exagerada e em uma obsessão" ${ }^{, 53}$ (1896, p. 32). Pari passu, relativizou a concepção de delinquente natural ao reconhecer que a própria sociedade, nas suas relações de

\footnotetext{
${ }^{51}$ Principalmente porque a Espanha sofria uma influência muito maior da Igreja Católica, nesse país os postulados positivistas demoraram mais para ganhar terreno (LÓPEZ, 2004).

52 Jiménez de Asúa informa que "Lombroso dizia a seus amigos e discípulos que se ele não 'tivesse inventado a Antropologia Criminal, Salillas a havia criado"” (Apud GÓMEZ; MAÍLLO, 2007, p. 745).

${ }^{53}$ Tradução livre de: "Precisamente la antropología corre peligro de desvirtuarse en sus comienzos, porque el relieve que há empezado á conceder á lo pretendido anômalo, constituye poço á poço una generalización exagerada y luego una obsesión (SALILLAS, 1896, p. 32)
} 
propriedade, demonstra acentuado grau de delinquencia, a própria "humanidade tem se mostrado e se mostra naturalmente delinquente" 54 (Idem, p. 131).

Dorado Montero, tido como o expoente do correcionalismo (VIVANCOS, 2003; BITENCOURT, 2009), já bem influenciado pelo positivismo ${ }^{55}$ e pela ideia de tratamento, em seu El Derecho Protector de los Criminales, acaba por fazer uma defesa da teoria correcionalista, ampliando-a e reformando-a em relação à origem alemã, advogando a necessidade do estudo psíquico e antropológico do delinquente, atribuindo a ausência desta preocupação em Röder ao atraso da psicologia na época em que este escrevia. Mas, com toda a convicção teórica de Montero, este deixa passar a confissão de que o correcionalismo está "todavia no campo das conjecturas, das intuições e das afirmações vagas",56 (p. 203) e quanto às propostas realmente práticas que poderia sugerir para a reforma do delinquente, reconhece estar, "neste particular, em pleno período de alquimia"57 (1915-a, p. 227).

A fé cega no progresso da ciência, típica da modernidade, fez com que Dorado Montero acreditasse que todas as confessadas conjecturas antropológicas pudessem evoluir para dar uma resposta definitiva sobre a reforma moral do delinquente. Dorado chega a comparar a sua esperança no avanço da ortopedia moral com o necessário avanço da ortopedia física, esta ainda tendo que fazer uso de procedimentos violentos, de fora para dentro do corpo, dizendo aguardar o tempo em que o procedimento seja interno, em ambas as ortopedias, e que chegará o dia em que a ciência poderá mudar a própria vontade do ser humano, pois "se modificará também nosso interior psíquico" 58 (1915-a, p. 229).

A história provou que a ciência não tem uma evolução natural, como pensava Montero. Embalado por sentimentos individuais de cada teórico, o correcionalismo acaba por ter somente uma característica comum, a crença na mudança do ser humano por intermédio da pena. O correcionalismo, inclusive, demonstrou-se tão volúvel que serviu para qualquer tendência dogmática do direito penal, pois, defendendo que a sanção penal deveria ser algo

\footnotetext{
54 "la humanidad se ha mostrado y se muestra naturalmente delincuente" (Idem, p. 131).

${ }^{55}$ Montero passou dois anos, entre 1885 e 1887, estudando na Itália, ocasião em que teria se convertido em um defensor da orientação científica em que se encontrava imerso o direito italiano, em virtude do movimento positivista liderado por Lombroso (GÓMEZ; MAÍLLO, 2007).

${ }_{56}$ No original: "todavía en el campo de las conjeturas, de las intuiciones y de las afirmaciones vagas" (MONTERO, 1915-a, p. 203).

57 “em este particular, en pleno período de alquimia" (MONTERO, 1915-a, p. 227).

58 "nuestro interior psíquico" (MONTERO, 1915-a, p.229)
} 
bom, não importava se se estava punindo o doente, o anormal ou o criminoso responsável e amparado pelo livre arbítrio.

A aplicação e a execução da medida de segurança aos inimputáveis por intermédio do sistema penitenciário nas legislações hodiernas têm origem nesta concepção da pena como medida benéfica, uma vez que de outra forma não se poderia conceber que no direito penal permanecesse o tratamento de pessoas doentes ${ }^{59}$. Se a própria punição penitenciária se transformaria em tratamento penitenciário, não importava mais quem estava sendo tratado, se o são ou o doente, pois qualquer um passaria a estar submetido a um tratamento ${ }^{60}$.

Outro autor incluído na chamada escola correcionalista, Francisco Giner de los Rios, como os demais, não se acanhou em demonstrar suas ressalvas contra a certeza do próprio correcionalismo, principalmente no que se refere ao tênue limite entre o normal e o anormal, avaliação que, segundo Giner, estaria no âmbito do "obscuro", de vez que seria impossível à ciência estabelecer elementos seguros para fixar a diferença, porque "hoje, com nossos métodos psicológicos, não podemos fazê-lo. O pouco que se faz é muito incompleto" ([1904], p. 109).

Giner de los Rios, diferentemente de Salillas e Montero, não era médico nem jurista, mas sim filósofo. Foi Rios quem traduziu para o espanhol a obra de Röder e exerceu certa influência acadêmica sobre ao demais. Contudo, a despeito da diferença de formação entre os autores citados, as manifestações de todos em favor do correcionalismo têm caráter eminentemente filosófico. Conheciam e fizeram referência ao pensamento platônico de recuperação daquele que cometeu crime, procurando apresentar o correcionalismo espanhol, ou alemão, como consequência da evolução do pensamento humano.

O combate travado a respeito das finalidades da pena tinha o simples objetivo de superar a maldade e o ódio demonstrado na prática penal. O encarceramento, já realidade irreversível naquela época, não tinha sido suficiente para afastar as torturas e os suplícios que

\footnotetext{
${ }^{59}$ Dorado Montero defendeu no V Congresso de Antropologia Criminal, realizado em Amsterdam, no ano de 1901, a mudança de nomenclatura de pena para "medidas de preservación", que seriam aplicadas tanto aos imputáveis quanto aos inimputáveis (MONTERO, 1915-b, p. 13).

${ }^{60}$ Nas palavras de Montero: "Habrá peligrosos imputables y responsables, y los habrá también inimputables é irresponsables; unos y otros siendo criminales, están necesitados del tratamiento acomodado" (1915-b, 118).

61 "hoy, con nuestros métodos priscológicos, no podemos hacerlo. Lo poco que se hace, es muy incompleto" (RIOS, [1904], p. 109).
} 
se mantinham presentes no dia a dia penitenciário, e os autores tidos como correcionalistas viam na defesa da pena como um bem uma forma de humanizar o sistema punitivo.

A imagem que a palavra correcionalismo transmite hoje não é compatível com o que ela significava há mais de cem anos atrás. Os autores citados eram considerados verdadeiros progressistas naquele tempo ${ }^{62}$. O correcionalismo hoje significa acertadamente uma ingerência antidemocrática do Estado sobre o ser humano, mas nos tempos em que a preocupação com a pena se encerrava com o encarceramento, defender a correção do outro era o mesmo que pedir a participação da ciência, do Estado, na esfera penitenciária, ainda que esta tarefa tenha sido feita de forma exagerada, sem verdadeiros fundamentos científicos e com ambíguos sentimentos.

\subsubsection{Concepción Arenal}

$\mathrm{Na}$ introdução deste trabalho falou-se da importância e atualidade do pensamento de Concepción Arenal (1820-1893), mas não no que se refere ao que foi classificado como correcionalista, muito embora esta mulher, que foi obrigada a enfrentar diversas dificuldades e preconceitos para estudar e escrever, nunca tenha se preocupado em participar desta ou daquela escola dogmática. Aliás, dificilmente uma mulher teria voz na Academia do século XIX e Concepción ultrapassou barreiras intransponíveis, frequentou a universidade vestida de homem, escreveu com pseudônimos ou com nomes de outras pessoas, até conseguir o respeito da Espanha que, após a sua morte, ergueu um monumento em sua homenagem, feito do ferro derretido dos grilhões, correntes e argolas que eram usados nas prisões espanholas, contra os quais Arenal tanto lutou, e cujo uso enfim foi abandonado ${ }^{63}$.

Concecpión encontrou na filantropia uma arma contra a desumanidade das prisões da Espanha de sua época, procurou "compensar com a caridade o que faltava de justiça na organização social"64 (MARTíN, 1994, p. 81), porque, para ela, uma sociedade que via o sofrimento dos encarcerados e não fazia nada, antes de viabilizar qualquer moralização,

\footnotetext{
${ }^{62}$ Dorado Montero, por exemplo, foi denunciado por alunos seus de direito penal, em janeiro de 1897 , junto ao bispado de Salamanca, por suas "doutrinas errôneas e contrárias à religião católica, expostas em dita cátedra" (RABATÉ, 1997, p. 206) e embora não tenha sido excomungado, como pretendiam seus acusadores, suas teses foram classificadas como heresia por decisão da igreja.

${ }^{63}$ Segundo consta, o monumento foi levantado no "paseo de Rosales de Madri" (VILLENA, 2007).

${ }^{64}$ No original: "compensar con la caridad lo que falte de justicia en la organización social" (MARTÍN, 1994, p. $81)$.
} 
depravava ainda mais o ser humano. Decepcionada com a política que tinha levado seu país a inúmeras guerras internas e externas, nas quais perdeu o pai e o marido, fez de sua ação junto aos cárceres, hospitais e asilos, um protesto sem violência e, quando falava de moralidade, falava mais de se moralizar as prisões do que os presos. Em Foucault há uma definição de que "a política é a guerra continuada por outros meios"65 (1999, p. 22), que se encaixa perfeitamente aos propósitos de Concepción.

O próprio Salillas reconheceu que "não há possibilidade de filiá-la em nenhuma escola, de acomodá-la a nenhum modelo e de encaixá-la em nenhum padrão que não seja o de seu modo de ser, personalíssimo"66 (1894, p. 11-12); com efeito, a sinceridade de sentimentos que a movia em seus escritos era tanta, que não é possível sequer resumir ou relacionar taxativamente as suas ideias e propostas. O que se pode antecipar é que Concepción Arenal não era uma correcionalista no sentido em que a história do direito penal a designou. Em certo momento difícil de precisar, o pensamento original e extremamente corajoso dessa escritora espanhola foi apropriado, retirado de contexto e taxado de correcionalista para compor uma ideologia que não era a dela, ou seja, a de reforçar a conduta encarcerizadora do Estado.

Em uma época em que Lombroso alcançava o auge de reconhecimento e fama com sua tese do homem delinquente, Concepción ousou discordar com um argumento que preserva a sua verdade. Como pode a ciência conhecer o homem delinquente, se ela sequer conhece o homem? "A pergunta: quem é o apenado? Equivale a esta outra: quem é o homem? Para respondê-la, que dificuldades! Quantas dúvidas, opiniões diversas ou contraditórias, e regras distintas!"67(ARENAL, 1895-a, p. 128).

O correcionalismo, para Concepción, era um argumento de reforma da prisão, porque seria "necessário, pois, que a pena não humilhe o apenado, porque desde o momento em que ele se torna objeto de desprezo, difícil será que não seja desprezível, e a lei que contribui para

\footnotetext{
${ }^{65} \mathrm{Na}$ verdade Foucault inverte a proposição de Carl Von Clausewitz de que "a guerra não é mais a continuação da política por outros meios", ela "não somente é um ato político, mas um verdadeiro instrumento da política" (apud FOUCAULT, 2002, p. 22).

${ }^{66}$ Tradução livre de: "no hay posibilidad de filiarla en ninguna escuela, de acomodarla á ningún molde y de encasillarla en ningún patrón que no sea de su modo de ser pesonalismo" (SALILLAS, 1894, p. 11-12).

${ }^{67}$ Tradução livre de: "la pregunta ¿ Qué es el penado?, equivale á esta otra: ¿ Qué es el hombre? Para contestarla, i qué dificultades ! ¡ Cuántas dudas, opiniones diversas ó contradictórias, y reglas distintas!" (ARENAL, 1895-a, p. 128) (Grifo no original).
} 
lhe degradar é cúmplice de sua degradação, e se reincide, de sua reincidência"68 (Idem, Ibidem, p. 290). E, assim, correcionalismo, para a autora, significava pena educativa, prisão com o mínimo de condições para que o preso não saísse de lá piorado, pois como também foi observado, a evolução do comportamento nunca é neutra e, na prisão, a tendência era seguir o pior caminho.

O moralismo característico do século XIX, reforçado pela educação religiosa de Concepción, não impediu que esta ampliasse a sua própria visão de moralidade, no sentido de respeito à dignidade da pessoa: “o conhecimento do coração humano e a fria razão dizem, que a dignidade do homem é um poderoso elemento de moralidade, e contribui para desmoralizála o que a rebaixa" ${ }^{69}$ (Idem, Ibidem, p. 291).

Arenal via a prisão como instituição da justiça, o que se mostra difícil perceber ainda hoje, e a degradação daquela contribuiria sobremaneira para a degradação desta. A função correcional, que estava no próprio nome dos estabelecimentos prisionais ${ }^{70}$ e na legislação, deveria ser cumprida não tanto porque Concepción acreditasse na rígida disciplina, mas porque o descumprimento da lei significava a desmoralização da própria lei.

Aqui não há espaço para especificações, mas Concepción criticou todos os sistemas penitenciários em funcionamento na época em que escrevia. De uma forma ou de outra, qualquer um que examinasse tinha um defeito, uma falha, que ia de encontro com o seu sentimento de humanidade. Criticou a seletividade de encarceramento dos pobres, o tempo prolongado da prisão cautelar, o excessivo tempo de pena, combateu a prisão da mulher com

\footnotetext{
68 "es necessario, pues, que la pena no humille al penado, porque desde el momento em que se vea objeto de desprecio, difícil es que no sea despreciable, y la ley que contribuye á degradarle es cómplice de su degradación, y si reincide, de su reincidencia" (Idem, Ibidem, p. 290). Já para Concepción, diante do que é o encarceramento, "a circunstância de reincidir deve ser atenuante para o que reincide e agravante para a sociedade"(Idem, Ibidem, p. 275-276). Nas palavras da autora: "la circunstancia de reincidir debe ser atenuante para el que reincide, y agravante para la sociedad, que comete el atentado moral de poner á un hombre, bajo influencias depravadas, y luego, la doble injusticia de pedirle cuenta, é el solo, del mal que ella tiene tanta parte" (Idem, Ibidem, p. 275276) (Grifo no original).

${ }^{69}$ No original: "el conocimiento del corazón humano y la fría razón dicem, que la dignidad del hombre es un poderoso elemento de moralidad, y que contribuye á desmoralizarle el que de cualquier modo le rebaja" (Idem, Ibidem, p. 291).

${ }^{70}$ Já no antigo regime, as prisões na Espanha eram meros apêndices dos quartéis e denominavam-se "presidios correcionales del Reino", enquanto no início do século XIX aos poucos as prisões vão saindo da jurisdição militar e altera-se a denominação de presídio para "casa de corección de costumbres" (ALBACETE, 1999, p. 118). Por isso chega-se a denominar de "novo correcionalismo" (Idem, p. 129) o que nasce no século XIX, diante da antiga tradição militar.
} 
filho menor, a ausência de pessoal qualificado nas prisões, seus baixos salários, a falta de escolas, a mistura de presos, a tortura institucionalizada; enfim, eram tantas as críticas de Concepción à prisão, que parece mesmo, que se a autora escrevesse hoje, depois de tantas reformas e remendos na instituição prisão, os quais não surtiram muito efeito, seria ela classificada de abolicionista e não de correcionalista.

Contrária ao isolamento absoluto, tão em voga naquele tempo, possuía um argumento que hoje, bem se sabe, serve para a prisão como um todo: "não se pode fazer próprio para a sociedade o homem, senão por intermédio da sociedade"71 (ARENAL, 1895-b, p. 79). E ainda porque haveria uma perda da dignidade nesse tipo de enclausuramento, uma vez que "viver para o homem é perceber variedade de sensações e comunicar”72 (Idem, Ibidem, p. 58).

Sempre revelando suas incertezas em tudo quanto se refere à chamada ciência penitenciária, diferentemente dos positivistas italianos e de seus conterrâneos correcionalistas, Concepción não foi a favor da pena indeterminada, ou seja, até a demonstração da correção do preso. Muito pelo contrário, censurou, no que se refere ao tempo de pena a "regularidade mecânica e a exatidão matemática" que falsamente encobre a atividade punitiva, onde há "profundos filósofos, legisladores e juízes afortunados, que caminham com tanta segurança por caminhos estreitos e rodeados de abismos",73 (Idem, Ibidem, p. 218).

\begin{abstract}
"Oito, dez, vinte, trinta anos de prisão: diz o legislador. Pensou bem o que disse? Talvez não. Acaso aplica ao tempo de cativeiro a medida de seu tempo em liberdade, e calcula, por horas que goza, a duração das de quem sofre [...] porque não há equivalência possível entre a liberdade e o cativeiro"74 (Idem, Ibidem, p. 230-231).
\end{abstract}

Quanto ao estado das prisões na Espanha: "Há anos a estudar o estado de nossas prisões, nos parecia que não era possível que piorassem, que qualquer variação havia de ser útil, qualquer mudança benéfica. Nos enganamos"75 (Idem, Ibidem, p. 370); observação que

\footnotetext{
${ }^{71}$ Livre tradução de: "no se puede hacer proprio para la sociedad el hombre, sino por medio de la sociedad" (Idem, Ibidem, p. 79) (Grifo no original).

72 "vivir, para el hombre, es percibir variedad de sensaciones y comunicar" (Idem, Ibidem, p. 58)

73 "regularidadd mecânica y exactidud matemática”; "¡Profundos filósofos, legisladores y jueces afortunados, que caminan con tanta seguridad por sendas estrechas y rodeadas de abismos!" (Idem, Ibidem, p. 218).

${ }^{74}$ Tradução livre de: "Ocho, diez, veinte, treinta años de presídio: dice el legislador. ¿ Ha pensado bien en lo que dice? Tal vez no. Acaso aplica al tiempo del cautiverio la medida de su tiempo de liberdad y calcula, por las horas en que goza, la duración de las de quien sufre [...] porque no hay equivalencia posible entre la liberdad y el cautiverio" (Idem, Ibidem, p. 231)

75 "Hace años, al estudiar el estado de nuestras prisiones, nos parecia que no era posible empeorarle, que cualquiera variación había de ser útil, cualquier cambio beneficioso. Nos enganábamos.” (Idem, Ibidem, p. 370)
} 
faz no final de sua obra chamada Estudios Penitenciarios e que demonstra acentuado grau de decepção com o ideal reformador da prisão.

Quando se dá conta de que tudo isso foi escrito no século XIX, fascina a profundidade e coerência da visão da autora, que ainda defendeu a participação da sociedade no problema carcerário e a multidisciplinaridade entre as ciências, estas que às vezes se tornam obscurecidas com o obscurecimento de apenas uma ou se tornam iluminadas com o avanço de outra. Nas palavras cheias de romantismo de Concepción:

As ciências, como que formam parte de uma harmonia, se auxiliam mutuamente; contudo, nas sociais é mais direta e ativa esta influência mútua: os golpes repercutem nelas com mais presteza e intensidade, e não se pode iluminar nem obscurecer uma, sem que de pronto todas se cubram de sombra ou reflitam a luz ${ }^{76}$ (Idem, Ibidem, p. $350)$.

Mas Concepción não se resumiu à crítica estreita do sistema penitenciário e mesmo não adotando qualquer posicionamento partidário por esta ou aquela corrente política, não se furtou a realçar o egoísmo imperante em uma sociedade que tem a propriedade como valor primordial, dizendo que "ninguém poderá fazer que a propriedade seja honrada, quando não é honrado o homem"77 (ARENAL apud AZCÁRATE, 1894, p. 70). De forma mais direta e, a nosso ver, extremamente atual: "Na Espanha, é insignificante a quantidade do que é roubado por ladrões que estão no presídio, comparada com o que é roubado pelos que desfrutam em liberdade o fruto de suas rapinas, legais algumas vezes, ilegais outras"78 (ARENAL apud SALILLAS, 1894, p. 31-32).

Do pouco que se extraiu dos ensinamentos de Concepción Arenal bem se vê que dela não se pode tirar qualquer base para o ideal de ressocialização, a não ser no sentido de uma maior socialização para todos os integrantes da sociedade, nunca uma forma de legitimar o encarceramento como meio de reabilitar quem quer que seja para a vida em liberdade. Concepción estava certa ao ver dificuldade não só no capitalismo, pois independentemente de

\footnotetext{
${ }^{76}$ Tradução livre de: "Las ciencias, como que forman parte de una armonía, se auxilian mutuamente; pero em las socieales es más directa e activa esta influencia mutua: los golpes repercuten en ellas con más presteza é intensidad, y no se puede iluminar ni oscurecer una, sin que muy pronto todas se cubran de sombra ó reflejen la luz" (Idem, Ibidem, p. 350).

${ }^{77}$ Tradução de: "nadie podrá hacer que la propriedad sea honrada, cuando no es honrado el hombre" (ARENAL apud AZCÁRATE, 1894, p. 70) (Grifo no original)

78 "en España, es una cantidad insignificante la que roban los ladrones que están en presidio, comparada con lo robado por los que disfrutan en la liberdad el fruto de sus rapiñas, legales unas vezes, ilegales otras" (ARENAL apud SALILLAS, 1894, p. 31-32).
} 
se a defesa era a favor do capitalismo ou do socialismo, como poderia algum sistema triunfar se o homem não tiver o mínimo de capacidade de se associar ${ }^{79}$.

Nada no correcionalismo foi baseado em situações empíricas de uma verdadeira correção do outro. Mas classificar Concepción Arenal simplesmente como correcionalista é criar um obstáculo à própria ciência, porque suas conclusões claras e objetivas muito poderiam contribuir para fazermos ver que nossa crítica é velha e antiquada, como é antiga e superada a instituição prisão. Já que pretendemos falar de diálogo neste trabalho, vem a calhar a observação de que a ciência não tem aberto espaço para o diálogo nem com ela mesma, com suas observações do passado, como se as conclusões tidas como científicas hoje não tivessem uma história de dúvida e titubeio, vacilações que seguem dissimuladas.

\subsection{FINS DA PENA E O IDEAL DE RESSOCIALIZAÇÃO}

$\mathrm{Na}$ história da pena dois tipos de atores ficaram bem definidos. De um lado havia aqueles que escreviam sobre a pena e suas funções, preparavam legislações e ganhavam fama com teses e livros publicados. Do outro lado ficavam os atores que trabalhavam de fato com a pena de prisão. Estes, quando tinham recursos e espaço, conseguiam uma reforma aqui e outras ali no edifício, montavam um ou outro pavilhão de trabalho para os presos, mas quando não havia verba suficiente, como foi a maioria das vezes, gastavam o tempo com ajustes, alocando um ser humano lá outro cá para que pudessem dormir ou se esforçando para que a alimentação satisfizesse o máximo possível de pessoas.

Bem, estes últimos não tiveram muito tempo para escrever sobre a prisão. A prisão não permite muito tempo para se refletir sobre ela mesma, porque a prisão é o caos, aliás, o “"caos” é seu próprio sentido e sua própria ordem" (SÁ, 2009, p. 16), enquanto isso quem escrevia sobre as funções da pena o fazia, como se está fazendo agora, de um local bem distante da prisão.

\footnotetext{
${ }^{79}$ Dizia para o trabalhador quase de forma revolucionária que, diante da injustiça social, "o remédio de seus males não está no socialismo, mas sim na associação" (ARENAL apud AZCÁRATE, 1894, p. 71). Grifado no original: "el remédio de sus males no está en el socialismo, sino en la asociación".
} 
Ocorre que o caos não se justifica e por isso todas as funções da pena giram em torno da metafísica. São funções fillosoficamente construídas para dar alguma aparência de racionalidade à prática jurídica que adota a pena de prisão como sanção fundamental na sua estrutura.

Assim, a prisão ganhou o nome pomposo de pena privativa de liberdade, como se fosse só a liberdade que se estivesse privando daquele condenado. Pior, como se fosse só daquele condenado que se estivesse privando algo. Mas, no momento, não vem ao caso continuar falando dos males da prisão. Diante de tanta diversidade, profissionais preocupados com a sobrevivência no caos e outros dissertando sobre os fins da pena, pouca coisa racional podia ou pode ser dita. Muitos falaram, mas pouco se disse.

Como bem lembra Hassemer (2007), só cresceu a necessidade de se fundamentar a pena em razão do nascimento da prisão. Antes, com o suplício, a morte ou a multa, a pena era aplicada de imediato, mas com a prisão havia o tempo de aplicação da pena, um período vago na vida do preso que precisava ser fundamentado.

Para este trabalho é necessário, com fins metodológicos, ainda que cansativo, repetir a conclusão a que chegou a dogmática sobre as funções da pena, antes de explicar no que acabou se convertendo o que se chama ressocialização atualmente.

Há um manuscrito de uma aula de Hegel intitulado manuscrito Homeyer, oriundo do curso de inverno dos anos de 1818-1819. São comentários orais do filósofo alemão sobre o seu próprio trabalho de Filosofia do Direito, anotados por um estudante de nome Homeyer. Pois bem, há uma passagem interessante nesse manuscrito, quando o professor falava dos fins da pena, que merece ser citada:

\footnotetext{
Este castigo já não consiste em pagar subjetivamente com a vingança: transforma-se numa reconciliação do direito consigo mesmo, como universal e como lei válida para o próprio criminoso e protegendo-o a ele tanto como aos outros: em pena. (A vingança é um direito em si, mas não numa forma de direito - estou fatigado - a vingança é por sua vez uma ofensa, e assim sucessivamente, até o infinito; a pena, essa, reconcilia) (HEGEL, 1979, p. 49) (Grifei).
}

Seria engraçada, se não fosse muito importante, a observação: falar sobre as funções da pena, fatiga. Não há como saber se o estou fatigado que consta no meio do manuscrito, entre travessões, se refere ao cansaço do aluno ou do professor, mas o certo é que falar sobre as 
finalidades da pena, repetindo tudo que já se disse, cansa. Não só porque é repetição, mas porque se repete para convencer, para legitimar o que é totalmente dissociado da realidade. Por isso, podemos ser breves.

Além do simples fim de retribuição, o qual a doutrina abriga na chamada teoria absoluta, os demais fins propostos para a pena compõem a teoria relativa e estão divididos entre os que têm caráter geral, isto é, são direcionados à sociedade, e os que têm caráter especial, os quais visam ao autor do delito. O fim dado à pena por Hegel, expresso acima em rápida citação, tem caráter geral, pois, para ele, a pena é uma reafirmação do ordenamento jurídico, portanto serve para reforçar os valores que foram violados com o descumprimento da norma penal.

Mas também tem caráter geral o fim dado à pena por Beccaria e pelo extremado utilitarismo de Bentham, quando esperam da pena um poder de intimidação. A exemplaridade da punição faria com que outros na socieade não vissem vantagem em cometer crimes.

A força de intimidação exercida pela lei é o que a doutrina chama de prevenção geral negativa, e a aplicação da lei como reforço de valores é considerada prevenção geral positiva. Haveria uma função educativa na prevenção geral positiva, mas de caráter geral. (CAMARGO, 2002-b).

Para a prevenção especial têm-se também duas formulações. A primeira seria simplesmente pela segregação do delinquente, tolhendo-o da possibilidade material de cometer outros crimes, cumprindo "uma função imediata de segurança, praticamente garantida à sociedade pela ausência do elemento ameaçador (BRUNO, 1984, p. 49) ${ }^{80}$. A segunda seria a que é objeto deste trabalho, a ressocialização, que seria a reforma moral ou psicológica - aí dependendo daquilo em que reformador acreditar - do criminoso enquanto submetido às instituições punitivas do Estado.

\footnotetext{
${ }^{80}$ Para Zaffaroni, Nilo Batista, et al., "ao nível teórico, a idéia de uma sanção jurídica é incompatível com a criação de um mero obstáculo mecânico ou físico, porque este não motiva o comportamento, mas apenas o impede, o que fere o conceito de pessoa (art. $1^{\circ}$ da Declaração Universal dos Direitos Humanos e art. $1^{\circ}$ da Convenção Americana sobre Direitos Humanos), cuja autonomia ética lhe permite orientar-se conforme o sentido. Por isso, a mera neutralização física está fora do conceito de direito, pelo menos em nosso atual horizonte cultural" (2003, p. 128) (Grifo no original).
} 
Esta é uma visão simplista dos fins da pena, mas suficiente para os objetivos deste trabalho. De uma forma melhor ou pior edificada, a história demonstrou que todos esses fins aparecem desde a antiguidade nas intenções de reis, legisladores ou reformadores. O nosso Código Penal é exemplo de que tais fins da pena não precisam estar separados, e dispõe que a pena tem como fim tanto de prevenção quanto de repressão (art. 59). Por isso é preferível ficar com Tobias Barreto (1990) e considerar relegados a metafísica os debates relacionados à finalidade da pena, baseados mais em conceitos políticos do que verdadeiramente jurídicos.

Como a história, em geral, para Cioran, com a pena acontece o mesmo, "há um pulular de fins tão divergentes e fantasiosos que a ideia de finalidade se anulou e se desvanece como irrisório artigo do espírito" (2011, p. 42).

Entretanto, tendo se tornado a ressocialização mais do que um fim para a pena, mais do que um ideal punitivo, superando inclusive qualquer concepção política de controle ou de força sobre o ser humano, e tendo se tornado um instrumento de várias funções, pois compõe discursos jurídicos da mais variada espécie, desde o punitivo até o abolicionista, é necessário continuar falando sobre isso.

A doutrina jurídica que melhor explica o ideal ressocializador é a da que se denomina Escola da Nova Defesa Social. Tal doutrina, se não é responsável pela construção do fim ressocializador da pena, sem dúvida a ela se pode atribuir a renovação de forças desse ideal.

Os expoentes dessa escola foram Filippo Gramatica e Marc Ancel. O primeiro criou, em 1945, em Gênova, um Centro de Estudos de Defesa Social, para inaugurar um movimento que resultou no reconhecimento da ONU, com o surgimento da Seção de Defesa Social, além da realização de diversos congressos e da criação da Sociedade Internacional de Defesa Social, em 1949, sob a presidência do mesmo Fellipo Gramatica (SILVA, 1991).

O nome Escola da Nova Defesa Social foi dado para fazer contraste com a Escola Positivista de Lombroso, Ferri e Garofalo, porque, como vimos, os italianos defendiam a aplicação da pena em nome da defesa social. O estudo do criminoso, a recuperação, eram necessários em benefício da sociedade, em defesa da qual não se mediria esforços. 
A Nova Defesa Social também se opunha à defesa social de Adolph Prins, a qual, conquanto em 1910 já defendesse um uso mais racional da pena de prisão, objetivava "garantir, com medidas apropriadas, o patrimônio de segurança e de moralidade social cuja custódia nos está confiada"81 (PRINS, 2010, p. 51).

Felippo Gramatica era o mais radical dos dois precursores da nova defesa social, sua elaboração era a de um verdadeiro novo Estado de Defesa Social, um estado preventivo em que o máximo de sua eficiência levaria à abolição da pena privativa de liberdade. Em compensação, suas medidas de defesa social poderiam ser aplicadas independentemente do cometimento de crimes. Explicando melhor: nessa formação estatal haveria a previsão de condutas antissociais, às quais seriam aplicadas as medidas, educacionais, médicas, sociais, mas sempre com o intuito de trazer um benefício para o cidadão considerado antissocial.

Gramatica chegou à conclusão de que a Escola Positivista, procurando dar ênfase à pessoa do delinquente, acabou criando o estigma do delinquente, porque a partir de então a sociedade ficou dividida em delinquentes e não delinquentes. Partindo desta constatação, para substituir a figura do delinquente foi criada a figura do antissocial. E o que é preciso fazer com um ser antissocial? A resposta é evidente: socializá-lo.

Como a Escola Positivista pensava em reformar o homem que era diferente, doente ou com alguma patologia genética, esta que por vezes tirava qualquer esperança de reforma e levava os autores daquela escola a defenderem a pena de morte, a Nova Escola de Defesa Social não iria mais tentar a reforma, porque o ser antissocial não é um ser humano diferente só porque cometeu um fato contrário à lei, mas vai tentar corrigi-lo para o convívio social (GRAMATICA, 1974).

É um dever da sociedade, por ser a garantidora de um bom convívio entre os cidadãos, promover essa espécie de ressocialização do antissocial, principalmente com medidas preventivas. Assim, esse Estado de Defesa Social de Gramatica, antes de tudo, teria que acabar com todas as condições favorecedoras do que fosse considerado comportamento

\footnotetext{
${ }^{81}$ No original: "salvaguardar, com medidas apropriadas, el patrimonio de la seguridad y de la moralidad social cuya custodia nos está confiada” (PRINS, 2010, p. 51).
} 
antissocial, como a pobreza, o aumento desenfreado da natalidade, a venda descontrolada de bebidas alcoólicas etc. (Idem, Ibidem).

Bem se vê o reforço que foi ganhando a ideia de (res)socialização, pois veio em oposição à concepção de tratamento exclusivamente médico, partindo de uma constatação coerente de que uma pessoa normal pode se tornar um delinquente. Contudo, o fim do direito penal e a adoção de um Direito de Defesa Social acarretariam a perda de algumas garantias históricas, pois condicionariam a concepção de antissociabilidade e o método de socialização a conceitos subjetivos, o que, além da ideia abolicionista, foi o principal motivo para que suas proposições não ganhassem apoio da maioria.

Sem embargo, o movimento cresceu e o entusiasmo de Gramática deu frutos. Marc Ancel viria para conter o exagero inicial, mas o direito penal ganhou novos ares, passou a aceitar conceitos que antes lhe eram estranhos, diminuía-se o tecnicismo jurídico e o reacionarismo nazifascista que imperava no Direito pós segunda guerra mundial. Nas palavras de Evandro Lins e Silva, a ciência penal "saía do litoral e voltava a encarar o horizonte. Olhava para frente e voltava a ser uma ciência arejada, sem teias de aranha a proibir-lhe o convívio com outras ciências, na sua origem e sobretudo na sua aplicação a seres humanos" (1991, p. 31)

À Marc Ancel se deve o acréscimo do adjetivo nova à corrente de defesa social que crescia, aliás quase que desordenadamente, com ideias de vários tipos, inclusive retrógradas no sentido de sugestões de esterilização de antissociais (GRAMATICA, 1974) ${ }^{82}$, mas a maior parte delas reconhecendo a desumanidade em que se tornou a atividade punitiva e buscando saídas para um direito penal mais científico.

Enquanto a concepção de Gramatica era mais de filosofia política, Marc Ancel buscava a mudança da estrutura do sistema penal, mantendo-o, mas abrindo espaços para considerações a respeito da personalidade do autor do delito. Tanto uma quanto outra concepção incorria no mesmo equívoco, sintoma da modernidade, de acreditar em uma

\footnotetext{
${ }^{82}$ Gramatica faz referência à proposta de Heuyer de que a esterilização de condenados é uma hipótese que não deve ser descartada, afirmando: "una mención que no debe infravalorarse: la «esterilización», de la que anteriormente hemos hablado" (1974, p. 323).
} 
mudança social com base em reformas legais ou em reformas do sistema punitivo, erro que era a base da Escola Positivista.

O trabalho de Marc Ancel, que era um magistrado francês, teve uma repercussão enorme. Logo se viu traduzido para oito idiomas ${ }^{83}$. Ele não pretendia criar um dogma, mas um movimento no sentido de humanização do direito penal. Possibilitando o ingresso das outras disciplinas e o debate em torno da questão da delinquência, Marc Ancel nunca poderia imaginar que estava criando espaços para o que depois Michel Foucault chamou de invasão das disciplinas na prisão, uma luta por poder no terreno abandonado do campo penitenciário (1998).

O reforço à ideia de ressocialização foi um pretexto para possibilitar a entrada dessas ciências e para a consequente humanização do direito penal. O resultado não foi o esperado, mas era essa a intenção do precursor daquela corrente, sendo o que se depreende de suas próprias palavras:

O conceito de defesa social conduz, assim, a um verdadeiro humanismo judiciário que tende a transformar, afora qualquer rejeição do sistema de direito penal, e de forma resoluta, a administração da própria justiça penal. Torna-se possível, então, conceber a defesa social, menos como uma doutrina objetiva do que como um engajamento, em sua acepção mais moderna: engajamento que aqui significa a aceitação deliberada de uma certa orientação a ser imprimida à reação anticriminal e à justiça penal, dentro do respeito à dignidade humana, e com a preocupação de reconduzir ao convívio social aqueles a quem esta reação social atinja (ANCEL, 1979, p. 14-16)

Vê-se que o engajamento para um direito penal mais humano passava pela preocupação de reconduzir ao convívio social o autor do delito, pela necessidade de fortalecer o discurso ressocializador. Ao mesmo tempo, "essa ação de ressocialização não pode entretanto se desenvolver senão por intermédio de uma humanização" (Idem, p. 18). Para ressocializar, humanizar, e para humanizar, ressocializar.

A estratégia da nova defesa social se demonstra evidente. Como convencer todos a aceitarem um direito penal mais humano, logo o direito penal que lida com os odiados, os inimigos da sociedade? Nem os direitos civis defendidos desde Beccaria, nem as rígidas regras

\footnotetext{
${ }^{83}$ Salo de Carvalho fixa o período de maior influência do movimento da nova defesa social: "o movimento adquiriu, no final dos anos setenta, caráter transnacional, universalizando seus princípios e finalidades, e agindo no câmbio de grande parte dos ordenamentos jurídico-penais e penitenciários da década precedente como, por exemplo, a legislação penal e penitenciária nacional de 1984" (2008, p.72)
} 
de tratamento do positivismo, nada fez com que meio social ou o poder público visse com simpatia qualquer iniciativa de humanização do sistema punitivo. Então, se não era possível abolir o sistema penal por completo, como queria Gramatica, o caminho foi criar um sistema que prometeria uma verdadeira defesa da sociedade por meio do direito penal, a ressocialização.

Aí se produziu uma nova teoria da ressocialização, explicitando que esta a partir de então só poderia se dar com o respeito ao ser humano, por intermédio de um direito penal humanizado. Em outras palavras, a ressocialização foi mesmo um subterfúgio para se alcançar essa humanização. A ressocialização foi um projeto de humanização do direito penal, mas não uma prática cientificamente comprovada.

E se o plano de humanizar o direito penal assumindo a pena de prisão como um dos instrumentos válidos já é contraditório, acrescentar a ressocialização como item humanizador da prisão é mais grave, porque acaba legitimando, reforçando mesmo, a pena de prisão como sanção coerente para o sistema.

O movimento da nova defesa social, tentando limitar o tecnicismo jurídico, trazendo considerações de outras ciências e possibilitando o estudo da personalidade do autor do fato, não conseguiu se ver livre do tecnicismo nem dos dogmas, até porque as outras ciências também têm os seus, mas acabou criando mais tecnicismo, mais dogma, no caso o da ressocialização.

Elías Neuman traz uma excelente visão do momento histórico da nova defesa social. O mundo pós segunda guerra mundial estava perplexo com o extermínio nazista de seres humanos, mas continuava mantendo os seus próprios campos de concentração. Por isso se fez necessária uma justificativa humanitária para o aprisionamento, a qual foi formalizada em Genebra, em 1955, por meio das Regras Mínimas para Tratamento dos Reclusos das Nações Unidas e, "à ideia de segregação se agrega a de tratamento carcerário. O cárcere serve, diziase, para recuperar seres humanos, o que se deve realizar com todos os meios a disposição" 84 (2001, p. 145).

\footnotetext{
${ }^{84}$ No original: "a la idea de segregación se agrega la del tratamiento carcelario. La cárcel sirve, se dice, para recuperar seres humanos, lo que debe realizarse com todos los medios de alcance" (2001, p. 145).
} 
Se há indícios de que, a partir dos anos 70, houve um declínio do ideal de ressocialização, seja na Academia, seja principalmente nas ações de política criminal, como demonstra o trabalho de David Garland, atribuindo como consequência desse descrédito do modelo ressocializador uma "modificação nas regras de elaboração das sentenças, que olvida a participação em programas de tratamento pelo tempo de cumprimento de pena" (2008, p. 500), veremos, entretanto, neste trabalho (a partir do item 3.4), que no Brasil ${ }^{85}$ ocorre justamente o contrário, com decisões judiciais continuando a fundamentar um maior encarceramento com base no ideal ressocializador.

Descrédito total para com a racionalidade que deveria haver na ciência do direito, falta de debate democrático, uma vez que o início do questionamento ao ideal ressocializador, baseado em pesquisas empíricas, se deu em um período de total ausência de liberdade política no Brasil, o certo é que no período apresentado pelo autor acima como de descrédito do ideal de ressocialização (anos 70 e seguintes), no nosso país ocorreu o oposto, com o reforço do argumento ressocializador, embalado inclusive pela edição da própria Lei de Execução Penal, de 1984.

\subsection{O CONTEÚDO DA PUNIÇÃO}

Cria-se um enorme desconforto quando são destruídos os fins da pena, porque a ciência deve ser feita com objetivos bons e humanos, deve servir para fazer o bem, e sem esses fins a pena parece se transformar em algo ruim, restando tão somente aquele "reservatório de vingança" inconsciente de que fala Winnicott (2005-b, p. 230). Acontece que, com ou sem os fins da pena, a prisão continua desdenhando da teoria e suas consequências caminham no sentido oposto aos fins de sua sustentação teórica. Portanto ela, a pena de prisão, não parece se transformar em algo ruim, ela é algo ruim, e os fins da pena cada vez mais perdem credibilidade para esconder isso.

Quanto mais precária é a tese de fim da pena, mais o fim se aproxima dos verdadeiros efeitos da prisão. A vingança, que na tese de Lombroso era um sentimento atávico que poderia

\footnotetext{
${ }^{85}$ Cumpre observar que o trabalho do autor citado se restringe à análise das situações dos EUA e da GrãBretanha.
} 
ser superado com a evolução da humanidade, é o fim da pena que mais se assemelha à realidade. Sobra, na pena de prisão, o mal pelo mal.

Mas o sentimento de vingança tem mais um inconveniente, além desse de deixar à mostra uma característica atávica ou uma paixão infantil negativa, ou seja, revelar a grande injustiça em que se torna a prática punitiva. Primeiramente, se assumida a vingança como motor do sistema, seria necessário aceitar a presença de sentimentos na atividade Estatal e o homem, que se esconde por trás da ciência e da pseudo neutralidade estatal, seria revelado ${ }^{86}$.

Mas o maior problema é que, colocando a vingança na reflexão sobre o ato de punir, voltaríamos a estar limitados ao talião, quer dizer, o mal da pena não poderia ultrapassar o mal cometido. Nas teorias construídas durante toda a história, o Estado sempre apareceu como um limitador dessa violência, como um ator neutro que viria para interromper a violência entre as partes. E assim, como ente sem sentimentos, constituído somente da lógica científica, interromperia a prática da violência e, para tanto, para cessar a violência, deveria dar lições de racionalidade. A partir de então a crença no Estado e no contrato social cresceu tanto que a vítima, a única da qual não se poderia exigir ser isenta de paixões, sumiu da relação punitiva.

Por isso as consequências da pena de prisão são tão camufladas, porque elas não passam no mais elementar teste de talião. Assumir o sentimento de vingança é ter que fazer reflexão e ter que perceber até onde se pode ir, mas a pena de prisão ultrapassa todos os limites. Desnecessário aqui enumerar os males da pena de prisão, porque muitos já fizeram e dissertações em todos os campos são escritas aproveitando tamanha incoerência. Mortes, mutilações, torturas, fome, privações das mais variadas espécies, fazem o dia a dia da prisão. Apenas como contraste, basta pensar na história humanizadora do direito penal e se perguntar até que ponto uma marca de ferro em brasa era pior do que alguns anos de cárcere.

Foucault (1998) tinha razão quando advertia que a pena de prisão não humanizou o direito penal, mas veio como um alívio, uma forma de não ferir os olhos delicados do juiz e da

\footnotetext{
${ }^{86}$ Stuart Banner, depois de explicar que o sentimento de vingança sempre está latente em todo o sistema legal, informa que desde o início do século XX, falar de retribuição é tido como acientífico: "but to speak up in favor of retribuition as a ground for punishment was, in the early twentieth century, to brand oneself unscientific" (2003, p. 212)
} 
sociedade com tanto suplício. Varrem-se para debaixo do tapete o suplício e o sofrimento que o acompanha, os quais continuam, mas agora fora de nossas sensíveis vistas ${ }^{87}$.

Seria esconder o sentimento de vingança uma forma de contê-lo? Caso a reflexão científica assumisse esse sentimento, poderia estar abrindo a possibilidade de dar vazão a um sentimento sem controle? Perderíamos parâmetros e a punição descambaria para o absurdo? Independentemente do fato de que a punição já descambou para o absurdo, a reflexão sobre esse sentimento, aliás a reflexão sobre qualquer coisa, é sempre salutar.

Não se precisa de subterfúgios para limitar a barbárie. As leis estão aí, basta cumprilas. Como bem explicitou Norberto Bobbio (1992), não é mais o caso de justificar direitos humanos, mas de efetivá-los. E não estamos efetivando justamente porque não se fazem reflexões sobre as causas psicológicas, sociais e econômicas de tanto descaso para com o outro.

Fazer reflexão é aproximar o pensamento da realidade, colocar o sentimento à mostra e poder aí sim limitá-lo. A vingança escondida só será contida quando se perceber o quanto ela já extrapolou o limite do razoável. E só uma reflexão adulta pode evitar que se continue tentando corrigir o outro pelo mal.

Shecaira lembra bem que Durkheim trouxe à consideração a vingança como fim da pena, porque a pena "consiste basicamente em uma reação passional, de intensidade graduada" (2008, p. 221). O sociólogo francês levava em consideração a proporcionalidade da pena para concluir que esta era uma retribuição, um talião moderno, porque para ele a vingança não é um sentimento ruim, mas um sentimento de defesa que não deve ser negado pela sociedade. Não havia problema na pena em si, mas tão somente no reconhecimento de sua natureza:

Entre a pena de hoje e a de outrora não há, portanto, um abismo; por conseguinte, não era necessário que a primeira se tornasse outra coisa que não ela mesma para se acomodar ao papel que desempenha em nossas sociedades civilizadas. Toda a diferença vem do fato de que ela produz seus efeitos com maior consciência do que faz. Ora, ainda que exerça uma certa influência sobre a realidade que ilumina, a

\footnotetext{
${ }^{87}$ A constatação de Foucault de que os suplícios foram desaparecendo para não ferir a sensibilidade dos demais está também em Giles Playfair e Derrick Sington que perceberam que a pena existente na Inglaterra de "cozinhar vivos certos malfeitores" foi sendo abandonada pelo mesmo motivo: "Na realidade, esse castigo, a mais bárbara de todas as punições inglesas, foi abolido no começo do século XV, não porque deixasse de dissuadir (pode-se presumir que era extremamente dissuasivo), mas porque se sustentava que tinha influência degradante sobre os espectadores" $(1969$, p. 28).
} 
consciência individual ou social não tem o poder de mudar sua natureza. A estrutura interna dos fenômenos permanece a mesma, sejam eles conscientes ou não. Portanto, podemos esperar que os elementos essenciais da pena sejam os mesmos de outrora (DURKHEIM, p. 59)

O funcionalismo de Durkheim não o deixou perceber que a pena, muito pelo contrário, não tem sido aplicada com maior consciência, contudo no seu texto há uma boa definição da essência da punição. Uma advertência, todavia, neste trabalho não se está defendendo que a vingança deva ser considerada finalidade da pena, mas somente que esta integre ao menos a reflexão de quem a aplica, porque no ato de punir, o juiz não é um instrumento mecânico e deve saber que está fazendo um mal. Não importa se esse mal se justifica ou não, é um ser humano aplicando um mal ao outro e se não houver reflexão, e este magistrado se sentir somente um mecanismo insensível da lei, a tendência é de que seja feito um mal maior, para ele e para o cidadão punido.

Como o sentimento de vingança, o mal é de difícil aceitação para o direito. A pseudo neutralidade da justiça e a impossibilidade de se compreender uma ciência que pratica o mal deixam muitos doutrinadores constrangidos em assumir essa característica, ainda que venha disfarçada de construção filosófica ou dogmática de finalidade da pena (PASCHOAL, 2003) ${ }^{88}$.

É ainda Winnicott que explica o processo de aprendizado da criança, preservando o que sente ser bom e afastando o que sente ser mal (2005-a), isto é, aprende-se com a dor da experiência. Na lógica punitiva não é diferente, sentimos que podemos corrigir o outro pela dor ou pelo medo, e tal observação é uma constante em todas as estratégias punitivas pensadas ao longo da história.

Infantil, instintivo, passível de reflexão, também é afastar o outro quando este quebra uma regra de convívio. Piaget (1994) lembra que a primeira atitude de um grupo de crianças quando percebe a violação de uma regra por parte de uma delas é o afastamento, a exclusão permanente ou temporária daquela criança. A prisão e o mal que a acompanha, então, seriam só um instinto infantil se não tivessem inúmeras outras causas políticas e econômicas, mas a reflexão é sempre importante.

\footnotetext{
${ }^{88}$ A autora lembra que, entretanto, não se deve confundir o fim da pena com o fim do direito penal, sendo o fim deste a proteção dos bens jurídicos de maior relevância para a sociedade.
} 
Quando falamos, na introdução, em Direito como diálogo, reconhecemos tratar-se de mais uma meta: fazer do Direito uma atividade dialogal; porque o que tem sido até agora é arbítrio disfarçado de ciência. E só se diminuirá essa circunstância com a assunção da verdade: a punição não é algo bom para ninguém.

O outro conteúdo da punição depende da consideração do primeiro. Vimos que quando as sociedades começaram a se organizar e a expressar as suas regras, o primeiro intento da punição era impedir a prática de outros crimes. O exemplo que não deve ser seguido. O medo do mal. O mal infringido e o mal futuro causando medo em quem pudesse ser uma ameaça para o convívio social.

Contudo nem este efeito terá a norma jurídica que não expressa a verdade, que mente, porque assim ela não é comunicação e não havendo diálogo nem o mal se compreende, porque se torna um espectro, um fantasma que não serve de exemplo, não ensina nada, causa somente horror e desorientação.

Dizendo de outra forma, outro conteúdo da punição é a censura, todavia esta só tem sentido se for comunicada. Enfim, prejudicada a comunicação do mal que se pretende corretivo, nem preventivo nem repressivo ele será. A repressão e a prevenção, previstas como fim da pena no Código Penal Brasileiro (art. 59), ficam prejudicadas. Permanecem como um belo ornamento na legislação, como se o sistema estivesse sendo útil à comunidade, protegendo-a com uma repressão que seria a resposta justa para o fato criminoso.

Quanto à prevenção, fantasiosamente, serviria para fazer o bem, um bem para a sociedade, evitando-se outros crimes, e outro para o próprio criminoso que será recuperado. Portando, não há nada de ruim na pena e podemos continuar aplicando o direito penal e sua principal sanção com a consciência tranquila de estarmos fazendo ciência, laborando para o bem da humanidade.

A ironia é necessária para evidenciar a distância que há entre a ciência penal e a punição do sistema. Pode-se mesmo considerar que não há punição no sistema penal, mas tão somente o uso do conceito de punição que é inerente a cada um de nós. O sistema exclui, segrega e mata cotidianamente e seletivamente, mas usa a ideia de punição para fazer um vínculo com um sentimento que carregamos internamente e assim busca legitimidade. 
$\mathrm{Na}$ justiça criminal, as atividades (e as experiências) formalmente denominadas castigos não são, pois assimiláveis aos eventos que, fora dela, são considerados como punição. $\mathrm{Na}$ prática, chamar tais atividades de punição significa criar uma legitimação infundada; em consequência não considero a justiça criminal como um sistema destinado a dispensar punições, mas sim um sistema que usa a linguagem da punição de modo a esconder os reais processos em curso e produzir consenso através de sua errônea apresentação, assimilando-os aos processos conhecidos e aceitos pelo público (HULSMAN, 2004, p. 36).

Se a punição como a concebemos e a sentimos está distante da realidade do sistema dito punitivo, nem a punição, que é sentimento, nem o sistema, construído sobre bases falsas, podem ser considerados científicos.

E o mais grave é sabermos da influência do sistema punitivo, a despeito de sua distância em termos de linguagem e de prática do meio social, no comportamento e concepção das pessoas, razão pela qual não deve ser irrelevante a preocupação em se constatar quanto o sistema punitivo usa e corrompe a própria ideia de punição inerente em cada um de nós.

Tudo parece racional só porque é oriundo das instituições que temos como naturais e não incluímos no nosso agir a possibilidade de estarmos em um padrão de conduta social irracional. Como ressalta Amartya Sen, "quando as razões para escolhas específicas são estabelecidas em nossa mente através da experiência e do hábito, é frequente escolhermos de forma suficientemente razoável sem nos preocuparmos com a racionalidade de cada decisão" (2011, p. 214).

Ocorre um círculo vicioso no qual o sistema é construído com base em sentimentos e se autossustenta com base nos mesmos sentimentos, mas disfarçado de regras e princípios que só reforçam tais sentimentos, fazendo com que constatações empíricas sejam meros detalhes dispensáveis.

\subsection{FUNÇÕES DA RESSOCIALIZAÇÃO: MITO OU MERCADORIA}

Por ser mais uma ficção do que um fim para a pena, o termo ressocialização sempre terá um conceito ambíguo, difícil de captar e, principalmente de expressar. Quando imposto como uma obrigação legal do Estado e como um dever do cidadão que delinquiu, pior ainda, porque como termo vago pode ser preenchido por qualquer conceito. 
Torna mais complexa a atividade de conceituar quando se percebe que não só há inúmeros sentidos para a mesma palavra ${ }^{89}$, mas que essa palavra se multiplica em um verdadeiro "leque de ideologias re: ressocialização, reeducação, reinserção, repersonalização, reindividualização, reincorporação" (ZAFFARONI; BATISTA; et al, 2006, p. 126) (Grifo no original).

E permanecer sem sentido faz parte de uma das funções da ressocialização, não só porque pode ser preenchida adequadamente de acordo com as intenções no exercício de poder, mas porque, como toda promessa, cria dependência e favorece o controle disciplinar (BOTELHO, 2005), e, neste sentido, quanto mais sem conteúdo for, mas abrangente pode ser, muito embora o tempo a torne precária.

São comuns as afirmativas de que "o mito da reeducação ou do tratamento já foi em grande parte desfeito pela realidade" (REALE JR, 2006, p.56), que "a reinserção social no seio da prisão é um mito e, como tal, serve como método de controle social para aplacar o mal estar da violência das ruas" ${ }^{90}$ (VIVANCOS, 2003, p. 9).

Contudo, o mito não serve somente para designar um aspecto negativo, como uma mentira, e assim esclarece Alvino Augusto de Sá, após fazer referência a Jung:

Por isto é que os mitos resistem ao tempo e chegam ao domínio da coletividade: é que eles são ricos de significado e as experiências profundas neles contidas são compartilhadas pela humanidade. Os mitos são símbolos e, enquanto tais, são capazes de transformar a energia pulsional. Eles são como telas, nas quais as energias pulsionais são projetadas, dinamizadas e transformadas. São reveladores de aspectos profundos da mente do homem, de sua história, de experiências profundas por que passou e à luz das quais interpreta a si mesmo, o universo e sua posição no universo. Os mitos são reveladores do inconsciente coletivo. Consequentemente, as verdades neles contidas costumam ser mais profundas e mais significativas que as verdades contidas nos fatos históricos. São verdades referentes à vida interior do homem, aos seus instintos, aspirações, temores e ao próprio inconsciente coletivo. São verdades dificilmente legíveis nos fatos históricos (2007, p. 26)

\footnotetext{
${ }^{89}$ Em Elias Neuman: “os termos 'readaptação social do delinquente' pertencem a uma linguagem enigmática e paradóxica. Existe um tácito assentimento quando são formulados e o mesmo ocorre com seus sinônimos: correção, emenda, reforma, adaptação, moralização, reabilitação, educação, reeducação, reinserção social e o galicismo ressocialização". No original: "los términos "readaptación social del delincuente' pertencen a un lenguaje sobreentendido, enigmático y paradójico. Existe un tácito asentimento cuando se los formula y lo mismo ocurre con sus presuntos sinônimos: corrección, enmienda, reforma, adaptación, moralización, rehabilitación, educación, reeducación, reinserción social e el galicismo ressocialización” (2001, p. 143-144).

${ }^{90}$ No orignial: "la reinserción social em el seno de la prisón es un mito social y, em tanto que mito, sirve como método de control social para aplacar al malestar de la violência callejera" (VIVANCOS, 2003, p. 9).
} 
Uma das dificuldades de lidar com um trabalho que pretende ser interdisciplinar é deparar com conceitos e visões diferentes entre duas ciências. Mas, pelo que se percebe, as características positiva e negativa do mito da ressocialização podem coexistir, e aceitar isso pode ajudar a entender a força que tem o ideal de ressocialização no meio social.

O fato de o mito revelar verdades inconscientes não significa que ele próprio seja uma verdade, e aí talvez esteja a grande importância do mito: quanto mais cedo nos dermos conta conscientemente de sua inverdade, e do quanto somos influenciados por ele, mais perto podemos estar de nos vermos livres dele.

Para Jung, o mito explica as coisas de maneira "alegorizante" (2002, p. 28) e não da maneira causal como a lógica e a razão iluministas ${ }^{91}$ nos acostumaram, portanto não cabe aqui trazer uma definição para algo que é interpretação, quanto mais de natureza metafísica. Também não há como descartar a hipótese de o mito ser usado negativamente, como uma mentira, seja por uma pessoa e principalmente pelo poder, pois “é possível enganar usando a melhor das verdades; é possível enganar com tudo" (JUNG, 1981, p. 281).

Além do mais, achar um mito que se adéque ao ideal de ressocialização não é difícil, pois o que mais se tem na mitologia é a ideia da transformação do homem, seja em animal, em fogo, em anjo ou em demônio, transformações essas que normalmente veem acompanhadas da dor, assim como todas as diversas punições igualmente presentes nos mitos.

Jung mesmo usou o Gênese e o mito de Prometeu para explicar um sentimento de culpa. Nessa interpretação, o conhecimento do homem subordinaria o contexto natural à arbitrariedade de sua consciência, e o homem assim se transforma e difere dos demais e "o tormento dessa solidão é a vingança dos deuses: tal homem não poderá voltar ao convívio humano. Como diz o mito, é agrilhoado à solitária rocha do Cáucaso, abandonado por deuses e homens" (2008, p. 42). Do texto original de Prometeu Acorrentado, ele foi punido para aprender: "Ele roubou o fogo - seu atributo, preciso fator das criações dos gênios, para

\footnotetext{
${ }^{91}$ John-Raphael Staude explica que Jung mantinha distância da política e pretendia nos advertir "quanto ao nosso 'atraso moral', que não acompanhou nosso progresso tecnológico e social. Falando como seu profético avô, o deão da Catedral da Basiléia, Jung denunciou a ausência de normas e o oportunismo do homem moderno. Ele advertiu que o homem moderno vendera todo o seu direito de primogenitura, o seu mito de preservação de vidas mantido no Cristianismo Protestante e na tradição, pelo ouro dos joguetes da modernidade e da secularização" $(1995$, p. 17)
} 
transmiti-los aos mortais! Terá, pois, que expiar este crime perante os deuses, para que aprenda a respeitar a potestade de Júpiter, e a renunciar a seu amor pela Humanidade" (ÉSQUILO, 1953, p. 7) (Grifo nosso).

Em Salo de Carvalho, a lembrança de que o mundo subterrâneo dos mortos foi herdado por Platão, filho de Saturno, a quem "cabia julgar e encaminhar os espectros ao Hades - reino formado por uma imensa planície subterrânea na qual os que cometeram grandes delitos na vida vagam e sofrem à espera da reencarnação" $(2008, \text { p. } 286)^{92}$.

Portanto, o mito pode e muitas vezes é ingrediente de uma construção ideológica ou mesmo componente de um estudo científico, visto que "não existe estudo sem uma determinação ideológica" (SÁ, 2011, p. 320). Tentando mais uma vez superar certa dessemelhança de conceitos entre ciências, podemos vislumbrar forte influência de mitos na construção ideológica: "A ideologia tem muita força, porque impulsionada por fantasias, instintos, desejos e mecanismos defensivos, no mais das vezes inconscientes, que demandam incessantemente alguma via de "solução"” (SÁ, Op. Cit., p. 319-320).

A referência no título do capítulo a mito e mercadoria conjuntamente é porque na nossa sociedade de consumo as mercadorias viram mitos e os mitos viram mercadorias. Eros Grau diz que há mitos modernos, cuja finalidade é a manutenção ou instauração de uma determinada ordem social, e são como “expressões exotéricas, a serem 'consumidas' pela sociedade. São impostos à sociedade, assim funcionando como instrumentos linguísticos de dominação que tanto mais prosperam quanto mais são acreditados” (2008, p. 177).

As relações capitalistas de produção carecem da alienação para se reproduzirem e assim seus produtos ganham mesmo a característica de mitos. "Fetichizando a mercadoria, a sociedade capitalista produz seus próprios mitos e, ao invés de santos nos altares e oferendas aos deuses, contempla artigos de luxo, de consumo cotidiano e até souvenirs" (SELBACH, 2006, p. 236). Por isso não é conveniente apenas relegar o mito à qualidade de uma mentira

\footnotetext{
${ }^{92}$ Em outro mito, em Alceste, de Eurípedes, das palavras do próprio Apolo: "Ó palácio de Admeto, onde me vi coagido a trabalhar como servo humilde, sendo embora deus, como sou! Júpiter assim o quis, porque tendo sido fulminado pelo raio um filho Esculápio, eu, justamente irritado, matei os Ciclopes, artífices do fogo celeste. E meu pai, para me punir, impôs-me a obrigação de servir a um homem, a um simples mortal!" (1953, p. 177).
} 
dispensável, mas sim a uma mentira que possa dizer a verdade de uma sujeição a qual o ser humano está submetido.

A dificuldade de, no direito, percebermos essa sujeição vem de outra concepção diferente entre ramos de conhecimento, que reside na definição de sujeito. Para o direito, o sujeito é o sujeito de direitos, livre e independente, enquanto para a psicanálise o sujeito "é o produto do discurso do Outro" (SILVA, 2003, p. 7) ${ }^{93}$, ou seja, produto de uma sujeição.

Portanto, afirmar isto é um mito não pode ter o significado de isto é uma mentira, mas sim significar um alerta, o de que estamos acomodados, submetidos (sujeitados) a uma estagnação que precisamos superar. Mito grego ou moderno, não interessa, porque a ressocialização não teria tido força dogmática e política se não estivesse sempre presente como característica da punição, seja com o nome de correção seja na qualidade de educação pela dor.

E a ciência do direito, como manifestação de poder que é, tem sabido fazer uso dessa situação. Como as relações de produção, que não produzem mais somente objetos, mas necessidades, com o fim de se autossustentarem, a ciência, que já não se mantém por ela mesma, precisa criar produtos que são vendidos e consumidos igualmente de forma alienada. Assim é o termo ressocialização que, a despeito da grande mentira que a própria palavra transmite por si só, é usado constantemente nos meios científico e social, servindo tanto para fundamentar a prática judiciária quanto para vender à população a ideia de que a prisão tem alguma utilidade.

Desmascara a ciência a confrontação de seus argumentos com a realidade, mas, mais do que isso, mostra como a ciência produz verdades. E, no caso do direito, como este vem se sustentando durante séculos produzindo ou mantendo verdades aleatoriamente. Por isso a grande semelhança entre a produção de verdades no direito e a produção de objetos para consumo no sistema capitalista. Algo precisa ser vendido, algo precisa ser renovado, reificado constantemente.

\footnotetext{
${ }^{93}$ Cyro Marcos da Silva nos mostra outro conceito distinto, o de indivíduo, porque individualizar para o direito é especificar, considerar o indivíduo com suas características e peculiaridades, ou seja, no direito podemos conceber a totalidade desse indivíduo, enquanto para psicanálise indivíduo é in-divíduo (dividido dentro), impossível de ser concretizado, individualizado na concepção do direito (2003).
} 
Como bem ressaltou Foucault, "temos que produzir a verdade como, afinal de contas, temos que produzir riquezas, e temos que produzir verdade para poder produzir riquezas" (1999, p. 29). Um paradoxo: o sistema penal, ao se utilizar de verdades ultrapassadas, de verdades que não se sustentam diante do mais singelo exame da realidade, deixa transparecer a sua dificuldade em criar novas verdades.

E assim, o que era desde o início uma verdade produzida, com o tempo e seu uso constante, vai se tornando um mito, um objeto de consumo em que tanto a necessidade quanto as consequências do seu uso são falsificadas, mas continuamos nos alimentando com isso. $\mathrm{O}$ mito, que já foi considerado "o passado da ciência e o oposto da ciência" (GARAUDY, 1966, p. 46), a qual se desenvolveria contra o mito, começa a se confundir com a ciência. Esta já não se atualiza, já não se baseia em hipóteses retificáveis, mas está estagnada no mito.

A ciência, que veio para nos proteger da violência arbitrária, vai se transformando em local de argumentos vazios impostos aleatoriamente que nada mais são do que violência. E o uso de uma mentira como argumento jurídico é violência cínica, quase física, pois violência é “a supressão do outro e da racionalidade, da integração e da solidariedade. A violência degenera a comunicação, cessa a reciprocidade, degrada a dignidade do outro" (BITTAR, 2009).

Mercadoria multifuncional que tem várias utilidades, a palavra ressocialização serve para dar um fundamento moral para a pena de prisão, serve para transferir a culpa da reincidência ao próprio preso, legitima o direito de punir, mantém viva uma sanção falida, serve para camuflar o verdadeiro intento de tão somente excluir.

Mesmo quando fica mais do que evidente que a ressocialização é uma prática inviável no cárcere, o próprio insucesso serve para indicar que a culpa não é do argumento pseudocientífico, mas de uma administração incompetente e ineficaz (RUSCHE, KIRCHHEIMER, 2004). Em outras palavras, a mentira se reifica no seu próprio desmascaramento. O Estado, no caso, não reconhece o exercício de poder falho, mas atribui a falha ao administrador da ocasião, protegendo o mito e se resguardando. Em 1844 Marx já dizia que a impotência estatal nunca será admitida e que a administração irá sempre 
reconhecer os defeitos como "formais, casuais, da mesma e [irá] tentar remediá-los" (p. 61, 2010).

No Brasil, a situação é mais grave, porque há uma séria tendência em se atribuir a falha na ressocialização à ineficiência comum do serviço público brasileiro, como se somente as penitenciárias daqui deixassem de cumprir o fim que a lei determina. E, com relação a este ponto, foi salutar a bibliografia alienígena até agora indicada neste trabalho, porque em nenhuma delas, em nenhum país, há a informação de que a prisão cumpre o ideal ressocializador, mas, ao contrário, em todas se verificam os mesmos males de uma prisão criminógena, favorecendo o aumento da criminalidade, com drogas, mortes e as demais mazelas que bem conhecemos.

Nos EUA, onde segundo a nossa cultura provinciana tudo funciona melhor, dois terços dos presos que iniciam uma high school não conseguem terminar, 56\% dos presos nas prisões estaduais, $45 \%$ nas prisões federais e $65 \%$ nas cadeias locais (Local Jail), apresentaram algum problema mental $^{94}$, a classificação de presos tem sido feita mais levando em conta a questão da segurança do que qualquer outro critério, o que proporciona problema de privilégios e benefícios sendo vedados injustamente, inclusive a oferta de trabalho interno (CLEAR; COLE; REISIG, 2009). Notícias de abusos sexuais contra visitantes, familiares de presos também não são raros. Com relação ao sistema em geral, em estudo na década de 90, mostrouse que um em cada três homens norte-americanos negros, já havia passado pelo encarceramento ${ }^{95}$ ou por alguma medida penal e mais de um latino, em dez também (DAVIS, 2003), indicando uma seletividade não tão diferente quanto a nossa ${ }^{96}$.

E a seletividade do sistema penal, constatada e reforçada pela seletividade das instituições carcerárias indica o oposto do que se pode pretender com o objetivo ressocializador, visto que este pressupõe, em seu inerente idealismo, uma quebra dessa mesma seletividade.

\footnotetext{
${ }^{94}$ Dados do Bureau of Justice Satistics, Special Report, September 2006 (CLEAR; COLE; REISIG, 2009).

${ }^{95} \mathrm{O}$ número entre as mulheres negras que teriam experimentado o sistema penal é de $78 \%$ no mesmo estudo (DAVIS, 2003).

${ }^{96}$ Sobre o assunto, tornou-se célebre o trabalho de Robert Martinson, de 1974, que concluiu sobre o sistema correcional norte-americano no sentido de que nothing works. Todavia, este mesmo trabalho é usado muitas vezes em sentido reacionário, não para diminuir o encarceramento, mas para que as autoridades justifiquem cortes de gastos com programas que seriam realizados em benefício dos presos (WALTERS, 1992), um perigo a que toda a crítica contra a ressocialização deve ter em mente.
} 
A prática judiciária, o discurso do dia a dia, as manifestações na imprensa, os manuais de direito, todos com referências à possibilidade de ressocialização no cárcere, constituem-se em um bombardeamento para o homem fragilizado, seja pela força do trabalho seja pela descrença na sua própria evolução como ser social.

Os homens inclinam-se a considerar a técnica como sendo algo em si mesma, um fim
em si mesmo, uma força própria, esquecendo que ela é a extensão do braço dos
homens. Os meios - e a técnica é um conceito de meios dirigidos à autoconservação
da espécie humana - são fetichizados, porque os fins - uma vida humana digna -
encontram-se encobertos e desconectados da consciência das pessoas. (ADORNO,
1995, p 132).

Veja-se que o mesmo efeito fetichizante que Marx atribui à mercadoria no mundo capitalista é conferido aos meios e à técnica por Adorno. É o que acontece com um argumento como a ressocialização, esteticamente belo, moralmente admissível e extremamente desejável.

Com tantas características boas já não interessa se na realidade o produto está longe de alcançar qualquer dos seus objetivos prometidos. Segue-se como que hipnotizado pelos fins anunciados pelo produto, sem capacidade de perceber sua inutilidade ou mesmo os seus malefícios. O produto ressocialização, assim, tem fácil aceitação no mercado e exerce grande poder sobre todos os que buscam tranquilidade diante das inúmeras atrocidades do cárcere. É fácil creditar tudo à esperança de uma, mesmo que distante, ressocialização.

Os técnicos do direito também se veem fascinados com a possibilidade de fundamentar um nocivo encarceramento. O produto, para estes, traz a promessa de servir para camuflar o verdadeiro propósito de retribuição: um unguento milagroso que faz dos males da prisão algo acidental.

Diante de tantas qualidades, a mídia não tem grandes dificuldades em propagar um produto. Na tela da televisão, no rádio, na internet, tudo é possível; qualquer discurso tem o poder de realizar o irrealizável, fortalecendo o caráter de mito do produto. É uma força poderosa agindo em dois sentidos, reforçando mitos e tornando o homem incapaz de exercer crítica sobre o produto.

Como adverte Shecaira, fazendo referência à Ramonet, “a informação é antes de mais nada uma 'mercancia'. Como toda mercadoria, está submetida às leis do mercado. Os valores 
que a presidem são a oferta e a procura, e não as regras que alguns poderiam pensar se relacionassem com os critérios cívicos e éticos (2001, p. 355-356).

Nesse contexto, em pior situação está o encarcerado ao final da pena que, após conviver vários anos com tanta hipocrisia, precisa ser dotado de forças sobre-humanas para alcançar qualquer adaptação ${ }^{97}$. E no interior do cárcere, se porventura surgir alguma atividade saudável, esta terá sempre o obstáculo do discurso ressocializador, porque o ser humano encarcerado sente na pele o absurdo que é ouvir falar em tal ideal.

Quando ocorre que alguém sai do cárcere e não reincide, logo tal fato vem como exemplo de que a prisão pode ressocializar. Embora ninguém tenha contribuído para a recuperação daquele ser humano, todos o usam como exemplo e o mito se renova. Se o preso consegue superar todos os males da prisão e amenizar as consequências psicológicas, físicas e sociais do tempo de encarceramento, ninguém a não ser ele pode dizer das razões e das circunstâncias que lhe proporcionaram essa resistência. Como afirmou Jean-Marie Gayu, "só a vontade interior pode eficazmente corrigir a si mesma” (2007, p. 49), e no caso, quando assim sucede na prisão, é apesar da prisão ${ }^{98}$.

No mesmo sentido, Janaína Paschoal aponta lição oriunda da experiência de Miguel Reale Júnior, de que é possível a mudança de postura do ser humano, "mas não por força da ação estatal. Um criminoso pode mudar de vida em razão de um amor, de uma perda pessoal, da adoção de uma religião etc. Esse paternalismo, essa falsa proteção remete a um autoritarismo do qual o Brasil vem tentando se afastar" (PASCHOAL, 2003, p. 102).

\footnotetext{
${ }^{97}$ Alvino Augusto de Sá ensina que "a mera passividade e sujeição poderão, aliás, colocar em risco a qualidade adaptativa. Adaptação não implica em sacrificar a própria individualidade e nem em criar com o ambiente uma relação de onipotência" (1987, p. 3). Embora feita em outro contexto, quanto à almejada adaptação, também a advertência de Adorno de que a adaptação ao sistema pode se constituir em uma desconsideração da própria individualidade: "El mecanismo de adaptación a unas relaciones encallecidas lo es al mismo tiempo de un encallecimiento del sujeto em sí mismo: cuanto más ajustado a la realidad se vuelve, tanto más se convierte em cosa, tanto menos vivo sigue..." (1991. p. 164).

${ }^{98}$ Angela Davis, referindo-se à biografia de Malcom X, conta que ele, fixado em ler e copiar cada definição do dicionário, declarou que "passou meses sem se sentir como prisioneiro. Na verdade, eu nunca tinha me sentido tão livre na minha vida" (months passed without my even thinking about being imprisoned. In fact, up to then, I never had been so truly free in my life). Mas ressalva que muitas vezes teve que ler infringindo o próprio regime penitenciário, lendo no chão de sua cela com a luz que vinha do corredor e tendo que voltar para a cama de dois em dois minutos, nas horas de passagem do guarda (2003, p. 53).
} 
Embora a reincidência seja efeito mais do que natural das condições do encarceramento, muito se poderia fazer para evitá-la, mas a crença na possibilidade de ressocialização transfere a culpa de sua não realização ao próprio apenado ou, como já ressaltado, à administração.

Mais do que paredes separam a sociedade do meio carcerário. Qualquer ação possível de aproximação da sociedade com o cárcere esbarra primeiramente, na ausência de sinceridade em que se baseia o sistema. E se já é difícil conceber um cárcere menos desumano só pelo simples fato de ser cárcere, o afastamento deste do meio social só agrava o isolamento e, consequentemente, sua desumanidade. 


\section{CONFLITO ENTRE LEGALIDADE E RESSOCIALIZAÇÃO NA JURISPRUDÊNCIA}

\subsection{LEGALIDADE PENAL E LEGITIMIDADE PUNITIVA}

Qualquer trabalho que envolva temas como punição, prisão e sistema penal, ao falar de legalidade deve ter o máximo cuidado em não descambar para a técnica pura ou para um sentimentalismo estéril. Depois do já falado, vir aqui dizer que o sistema jurídico funciona dentro dos estreitos limites de uma legalidade que traz consigo certeza, segurança jurídica e igualdade de tratamento entre todos, seria confessar um absoluto descompromisso com a realidade e, em consequência, para com um conhecimento que se pretende de caráter científico.

Logo se vê, entretanto, que conter a crítica é difícil diante de tanto sofrimento e de tema tão complexo. A técnica jurídica pode favorecer a beleza de um trabalho acadêmico, mas não permitirá a narração da angústia que se vive no interior do cárcere, onde verdadeiramente se realiza o direito penal. Assim, se é certo que os direitos humanos estão legislados e não precisam de fundamentação para se exigir a sua efetividade, a constatação da árdua tarefa, que é essa efetivação, nos faz crer ser necessária alguma coisa a mais.

\subsubsection{Princípio da legalidade da pena}

O princípio da legalidade está na Constituição Federal (art. 5 XXXIX) e no Código Penal Brasileiro (art. $1^{\circ}$ ), enunciado na doutrina pela renomada fórmula derivada da elaboração de Feuerbach: nullum crimen nulla poena sine lege ${ }^{99}$. Não há crime, não há pena, sem lei.

Pode-se argumentar que a legalidade pressupõe a legitimidade do sistema, sendo este um expediente comumente usado, mas absolutamente insustentável, porque, diferentemente da estrutura formal da lei escrita, esta só é legítima "quando existir correspondência entre o comando nela consubstanciado e o sentido admitido pelo todo social, a partir da realidade

\footnotetext{
${ }^{99}$ A fórmula original de Feuebach é "nulla poena sine lege, nulla poena sine crimine, nullum crimem sine poena legali” (ZAFFARONI; BATISTA; et al., 2003, p. 202).
} 
coletada como justificadora do preceito normatizado" (GRAU, p. 86, 2008) (Grifei). E a advertência tem redobrada importância no direito penal que em tese deveria regular os bens mais importantes do ordenamento jurídico, pois aplica as sanções mais severas ${ }^{100}$.

Fundamental a observação, conquanto não seja nosso tema no momento, de que quanto mais se vulgariza o direito penal, criando-se crimes e penas para toda conduta prevista pela fecunda criatividade de nosso legislador, tanto mais ele perde legitimidade, de vez que a própria sociedade desconhece o nível de negatividade valorizada pelo direito penal. Há um círculo vicioso de lei penal, perda de legitimidade, insegurança e mais lei penal.

Mas e a lei penal formalmente falando? Afastando esta questão de legitimidade e de política criminal, a lei penal é cumprida? Necessário responder por partes. Primeiramente, o Código Penal; depois que o réu é selecionado na rua por um policial, é submetido a um inquérito policial, denunciado e vai a julgamento, sim, o Código Penal é cumprido. O fato será subsumido ou não a um tipo legal e o réu será condenado ou absolvido. Nesta ocasião, diz a doutrina, o juiz deverá verificar se o tipo pelo qual o réu foi denunciado foi previsto previamente de forma clara e taxativa na lei penal.

Também não se incluem neste exame de legalidade duas questões fáticas que atingem, tanto a legitimidade quanto a própria legalidade do sistema penal. São elas o tempo de prisão provisória, a que a maioria desses clientes do direito penal são submetidos, porque estas prisões antes da sentença têm se transformado em verdadeiras penas, e o fato de que a seletividade do sistema é cada dia mais desigual.

Superando tais observações, o Código Penal, para julgar aquele crime, foi aplicado dentro da mais estrita legalidade. Mas lei penal não é só um ou todos os crimes previstos no Decreto-Lei 2.848/40, o Código Penal, mas todo um ordenamento jurídico composto por diversas outras leis.

Essa digressão foi necessária para demonstrar que o sistema, com todos os seus distúrbios e deficiências, respeita formalmente o princípio nullum crimem sine lege e seus

\footnotetext{
${ }^{100}$ De Sérgio Mazina Martins: "Embora tenhamos sido criados sob a crença de que a legitimação era um dado estático e inerte (posto) do Direito - decorrente de uma Constituição legítima por definição - agora porém encontramos nossa deontologia sob desafios freqüentes" (2000, p. 12)
} 
corolários. Só que falta o complemento do princípio da legalidade, esquecido pela doutrina, abandonado pelo judiciário, que é o nulla poena sine lege. Neste quesito tudo anda mal e resulta que a resposta para a pergunta acima é não, a lei penal não é cumprida.

O maior paradoxo está em perceber ser a lei que define o crime e impõe pena privativa de liberdade, a mesma que manda haver trabalho na prisão, cela individual e a obrigação de respeito à integridade física e moral do preso (arts. $34, \S 1^{\circ}$ e 38 do $\mathrm{CP}$ ); entretanto, só a parte determinante ao que é crime é cumprida. Isso sem contar que a reforma da parte geral do Código Penal se deu com a Lei 7.209/80 e a Lei de Execução Penal é a Lei 7.210/80, próximas na numeração, mas muito distantes na efetivação.

Voltemos, então, a Beccaria e seu Dos delitos e das penas, porque o enunciado de Feuerbach não tem muito a ver com a garantia que deveria ser o princípio da legalidade. Feuerbach formulou esse enunciado latino dentro de sua teoria da coação psicológica, defendendo que a necessidade de crime e pena estarem previstos em lei, decorria do efeito de intimidação que essa previsão ocasionaria no criminoso em potencial (ROXIN, 2007), ou seja, embora se tenha adotado a fórmula nullum crimem para designar o princípio da legalidade, esta nasceu dentro de uma teoria da prevenção geral.

O princípio da legalidade, usado na revolução francesa e enunciado na Declaração dos Direitos do Homem e do Cidadão, de $1789^{101}$, inicialmente garantia frente ao soberano, passa a ser garantia frente ao Estado e a sua construção teórica, para o direito penal, é atribuída a Beccaria. O Marquês, adotando então, no seu Dos delitos e das penas, o contrato social como parâmetro, usou o simbolismo do depósito de liberdades.

A lei e a soberania, a lei e sua legitimidade, derivam de um consenso e "nada mais são do que a soma de pequeninas porções da liberdade particular de cada um, representando a vontade geral, soma das vontades individuais" (BECCARIA, 1999, p. 90), e a "soma de todas essas porções de liberdade, sacrificadas ao bem de cada um, forma a soberania de uma nação e o Soberano é seu legítimo depositário e administrador” (Idem, Ibidem, p. 25).

\footnotetext{
${ }^{101}$ Em primeiro lugar é encontrado nas Constituições americanas da Virginia e Maryland, de 1776 e em seguida no Código Penal austríaco de 1787. Depois da Declaração dos Direitos do Homem e do Cidadão francesa, no Código Prussiano de 1794 (ROXIN, 2007).
} 
Foi este simbolismo a base da negativa de Beccaria à pena de morte. Quem em sã consciência depositaria a sua vida entregando-a para a administração do Estado? Portanto, nem na sua base filosófica pode-se encontrar argumentos para entender que o princípio da legalidade está sendo observado hoje em dia, pois quem confiaria a sua integridade física e a sua dignidade humana a um depósito público? Aliás, a prisão é mais do que violência à dignidade humana, é pena de morte em muitos casos.

Aqui se abre um parêntese para lembrar que no sistema penitenciário as penas de morte são aplicadas e executadas muitas vezes em circunstâncias piores do que na Idade Média, com presos morrendo queimados, fuzilados, enforcados, torturados etc. A única diferença é que os carrascos não precisam mais de máscaras, porque estão protegidos pelas paredes de penitenciárias, cadeias e delegacias, instituições austeras que funcionam com o aval e a indiferença do Estado.

Pode-se inclusive perceber que há um antagonismo entre violência e legitimidade, pois o poder só precisará daquela na medida em que lhe falta esta. Há "uma correlação negativa (ideal) entre poder e violência, de acordo com a qual o poder só existe quando a violência está ausente e esta só triunfa face a um poder em crise" (ESTEVES, 2003, p. 119-120) ${ }^{102}$ ou seja, em um contexto onde a violência sobressai não há que se falar de poder legítimo.

Voltando ao princípio da legalidade dogmático. Dele a doutrina deriva diversos mandamentos necessários para a sua própria validade, e entre os principais estão o princípio da estrita legalidade, o princípio da determinação e da taxatividade, além do princípio da irretroatividade (COSTA JR., 2009).

A estrita legalidade deriva da necessidade de que só leis validamente promulgadas possam estabelecer crimes e penas. Óbvio, porque pudesse o Estado editar leis aleatoriamente, sem cumprir as formalidades legais, a garantia do princípio da legalidade se diluiria no arbítrio do detentor do poder. Quanto ao princípio da irretroatividade, a mesma coisa, pois nenhuma

\footnotetext{
${ }^{102} \mathrm{O}$ autor cita Hannah Arendt: "«à violência é sempre dado destruir o poder, pois do cano de uma arma desponta o domínio mais eficaz, o que jamais poderá florescer da violência é o poder» (Arendt, 1985:29). A essência de tal antagonismo radica na natureza mais profunda de cada um dos fenômenos: a violência possui um caráter instrumental, orientada pela lógica meios-fins e exigindo, por isso mesmo, permanentes justificativas, o poder, pelo contrário, dispensa tais justificações, pois apenas depende da legitimidade que lhe é conferida pela vontade coletiva (cidadãos)" (ESTEVES, 2003, p. 120).
} 
garantia teria o cidadão se a sua conduta pudesse ser atingida posteriormente por uma lei da qual não tinha nem podia ter conhecimento.

Resta a determinação e a taxatividade, que são as consequências do princípio da legalidade que mais nos interessa, visto estarmos falando da abstração, que é a ressocialização na teoria da pena. A lei penal deve ser clara e precisa pois caso contrário, a punição que dela derivaria seria arbítrio e não lei. Não conhecendo o conteúdo da lei não podemos pautar nosso comportamento nem julgar o comportamento dos outros com base nessa lei, e a consequência é que tanto a sua validade quanto sua aplicação não estariam respeitando o princípio da legalidade.

Com relação à pena, especificamente, há outro princípio constitucional, o da individualização da pena (art. $5^{\circ}$, XLVI, da CF), que faz com que, com relação à sanção, não se possa ter uma exatidão completa, visto que esta deverá se adequar as condições e características do infrator. Todavia, nada pode haver que prejudique a clareza na determinação da pena e mesmo o processo de individualização, deve ser o mais nítido possível. E, igualmente, o princípio da individualização da pena não autoriza seja a pena prevista e individualizada uma, enquanto a executada outra, e é nesta observação que se deve insistir.

A doutrina produz livros e mais livros sobre o crime e reafirma constantemente que o princípio da legalidade é a limitação da atividade punitiva do Estado. Teorias de todos os tipos já esmiuçaram o fato criminoso no sentido de que a adequação da conduta criminosa fosse o mais condizente possível com o fato típico, o fato descrito na lei como crime. No entanto, a pena é comumente abandonada e a atividade punitiva do Estado fica de fato livre.

Talvez isso ocorra para não expor o sistema penal ao ridículo e não acentuar a perda de legitimidade do mesmo. Realmente, de tanta ilegalidade há de se tirar o mínimo de coerência para evitar um discurso meramente destrutivo, mas não vemos como essa tentativa de juntar e proteger os destroços do direito penal possa levar ao esquecimento por completo do princípio da legalidade da pena.

O fato tido como criminoso é analisado, esmiuçado e classificado como crime conforme as disposições da lei. E a pena, basta ser clara no papel, para estar satisfeito o princípio da legalidade? A partir desse princípio, o juiz poderia aplicar uma pena de prisão e a 
pena executada ser a de galés? Ora, os fatos da vida real, a pena realmente aplicada, as circunstâncias e características do sistema penal também integram a pena, aliás são o que verdadeiramente fazem a pena, e devem ser submetidas à consideração do juiz não só no momento da execução, mas igualmente no momento da aplicação.

Concepción Arenal já manifestava alguma impaciência neste desconsiderar da realidade: "Parece que antes de tudo o legislador deveria ter presente, ao estabelecer a lei, e os juízes ao aplicá-la, se aquela pode ser cumprida, se há de ser uma verdade, porque não podendo, resulta em algo como uma burla da razão e um escárnio da justiça”"103 (1895-a, p. 272).

Por isso que o princípio da legalidade da pena também deve assumir os corolários de determinação e taxatividade. Não só no sentido de que o legislador não pode impor genericamente penas abstratas, mas da mesma forma o juiz não pode impor penas que não correspondam à realidade, à pena que efetivamente se aplica.

Sabe-se da dificuldade de implementar tal princípio, notadamente se tratando de pena criminal, pois mesmo a taxatividade na tipificação de delitos tem sido gradativamente relativizada ${ }^{104} \mathrm{em}$ nome da neurose punitiva que tomou conta de todos, agravada pelo aumento das situações de risco da sociedade pós-moderna (SILVEIRA, 2003). Contudo, em um Estado Democrático de Direito não há espaço para uma punição ilegal em nome do medo.

Alguns autores começam a aceitar considerações sobre a pena na dogmática, contudo ainda é tímido esse procedimento. Um exemplo pode ser tirado de Tangerino que insere sua proposta de afastamento da pena mínima "em um contexto amplo de que a pena, por ser um recurso violento e negativo, deve ser evitada ao máximo" (2010, p. 242).

Exemplo mais remoto está em Roxin (2007), quando defende que, no caso de excesso de legítima defesa, o juiz deixe de aplicar a pena em razão da desnecessidade da prevenção de

\footnotetext{
${ }^{103}$ Tradução livre de: "Parece que ante todo debería tener presente el legislador al estabelecer la ley, y los jueces al aplicarla, se aquélla puede cumplimentarse, se há de ser uma verdad, porque de no serlo, resulta alguna cosa como una burla de la razón y un escárnio de la juticia" (ARENAL, 1895-a, p. 272).

${ }^{104}$ Frank Süb denuncia a grave situação de seu país nessa questão: "hoje em dia o mandado de determinação não está em condições de impedir nada. De acordo com as exigências - próprias de um Estado de Direito liberal - do direito penal alemão, esta é uma situação insustentável" (2000, p. 231). No original: "el mandato de determinación esté hoy en día em condiciones de impedir nada. De acordo con las exigencias - proprias de un Estado de Derecho liberal - del Derecho penal alemán, ésta es una situación insostenible”.
} 
novos delitos, visto que o autor não teria perdido a dimensão do certo ou errado. Assim, Roxin pretende incluir na culpabilidade, a necessidade preventiva da pena. Não obstante, é um posicionamento que continua partindo da perspectiva de uma pena capaz de prevenir algo, que pode ter algum aspecto bom, além de centrada na pessoa que delinquiu, sem considerar os males provocados ao autor do delito e à sociedade.

\subsubsection{Direito penal, direito penitenciário e execução penal}

Ao mesmo tempo em que a capacidade de conhecimento do ser humano é limitada, as condições de vida da sociedade se tornam cada vez mais complexas, obrigando seja o saber fragmentado e as ciências especializadas, cada uma com o seu objeto de estudo. Resumidamente, a particularização da ciência é uma limitação de seu objeto.

Dito isso, pode-se afirmar que com a especialização do direito penal, nele não se incluem considerações como estas que estamos fazendo neste trabalho. Ao que se contraargumenta, primeiramente, que a divisão do direito penal se deu para facilitar seu estudo e aplicação, para melhor fazer justiça, e não para o tornar alheio às considerações da realidade. Afinal, a justiça não se especializa, é sempre uma só.

E mais, a referência "a suas devidas perspectivas limitadoras, não deve ser confundida com a própria negação do conhecimento racional e muito menos ainda com a realidade do mundo" (ZAFFARONI; BATISTA; et al., 2006, p. 38). A limitação metodológica deve estar a serviço e não em prejuízo do conhecimento.

Em uma definição bem ampla, Nilo Batista conceitua o direito penal como "um conjunto de normas jurídicas que preveem os crimes e lhes cominam sanções, bem como disciplinam a incidência e validade de tais normas, a estrutura geral do crime, e a aplicação e execução das sanções cominadas" (2002, p. 24).

Já César Roberto Bitencourt apresenta um conceito restrito e diz que direito penal é "um conjunto de normas jurídicas que tem por objeto a determinação de infrações de natureza penal e suas sanções correspondentes - penas e medidas de segurança" (2004, p. 2), mas faz a 
ressalva de que em sua finalidade de regular as relações sociais o direito penal ganha o aspecto de ciência penal.

Qualquer ciência pode ser submetida a inúmeros conceitos, de acordo com o objeto que o cientista quer enfatizar. Não se pode perder de vista, entretanto, dando-se o conceito que se der, que o direito penal, normativo ou científico, divisão adotada por Roberto Lyra (1974-a), não pode prescindir da realidade como paradigma. O direito não pode ser um joguete alienado com nome de ciência, notadamente lidando com vidas humanas e com a sustentação das relações sociais.

A advertência não vem só do que foi dito acima, de que a doutrina costuma interpretar e elaborar teorias do direito penal destituídas de crítica com relação à realidade da punição, consequência extrema do direito penal. A prática jurisdicional como um todo tem se tornado alienada, como se o sistema funcionasse perfeitamente. As instituições, funcionários, advogados, que compõem o sistema penal fazem da dogmática o seu material de trabalho, mas uma dogmática limitada que não leva em consideração a realidade.

Quando a alienação não é total, a prática de se transferir culpa ajuda. Como constatado há pouco, é comum dizer que a pena não cumpre o seu papel por culpa da administração, o que significa dizer que ela poderia muito bem funcionar se o Estado fosse mais eficiente. E nesse passo seguem-se produzindo manuais de direito que estimulam ainda mais a desconsideração da verdade na prática punitiva.

Pensamos não ser a pena privativa de liberdade a solução única para todos os delitos, mas uma das mais adequadas para crimes considerados graves, quando o Estado Democrático de Direito não quer valer-se de sanções drásticas e definitivas, como a pena de morte ou de castigos corporais de toda ordem. É cumprida de modo severo, sem dúvida, mas muito mais por culpa daqueles que têm o dever legal de aparelhar e sustentar o sistema penitenciário do que por débito a ser imputado ao juiz ou ao legislador (NUCCI, 2009-b, p. 89).

E é exatamente o que muitos juízes e legisladores fazem, produzindo estes leis a toque de caixa, sem qualquer consideração com a realidade, pois, afinal, não é culpa deles, enquanto aqueles, os juízes, podem encarcerar, podem aplicar penas altas de prisão, já que assim estão sendo até benevolentes, considerando que o Estado Democrático de Direito não quer valer-se das penas de morte e castigos corporais. 
Como a especialização da ciência do direito, que deve favorecer a justiça, criando princípios e regras especiais para determinado objeto, mas nunca abdicando do conhecimento, que é um só, a separação de poderes do Estado veio em nome da melhor administração da justiça e não somente para estabelecer ou, melhor dizendo, isentar de responsabilidades. $\mathrm{O}$ Estado é um só, e o juiz não terá cumprido o seu papel de agente público se retirar de suas considerações a prática efetivamente realizada por um sistema do qual faz parte, notadamente se é esse funcionário público justamente o idealizado na divisão de poderes para se colocar como intermediário entre os direitos do cidadão e as ações do Estado.

Para tanto, o magistrado deve primeiro abandonar o pedestal em que a sua condição profissional pode deixá-lo, porque a "ideia de alta função social, a fazer com que o juiz se veja ocupando uma posição considerada superior na sociedade” (KARAM, 1994, p.122) apenas contribuirá para distanciá-lo cada vez mais das classes inferiores, de onde são selecionados os criminosos, dificultando o reconhecimento de valores com os quais não tem contato e pensando serem os seus, os valores dominantes no meio social, fazendo com isso morrer qualquer característica dialogal no direito.

Diz-se que o direito penal "preserva os cidadãos (e, com isso, os vigaristas também) de qualquer punição por um comportamento que não seja claramente declarado como punível no Código Penal antes da sua prática" (ROXIN, 2007, p. 67), assumindo a responsabilidade e a "possibilidade de que, dessa forma eventualmente, fique impune um ato especialmente refinado, socialmente nocivo e, por essa razão, digno de punição, [sendo] o preço (não demasiadamente alto) que o legislador tem que pagar pela segurança jurídica" (Idem, Ibidem).

Ora, o sistema punitivo como um todo deve assumir as responsabilidades de suas deficiências, a fim de manter um mínimo de coesão. Assim, se a pena não se executa de acordo com a lei, a mesma segurança jurídica que deve garantir que todos sejam punidos igualmente deve zelar para que a pena ilegal não seja nem aplicada ou que ao menos não se abuse dela. Este também é um preço demasiadamente alto, mas deve ser pago.

Outra divisão que nasceu para favorecer o método de trabalho e a melhor distribuição de justiça foi a separação do direito penal do direito de execução penal. Não se olvidando que “a pena vive na execução" (BETTIOL, apud BENETI, 1996, p. 7), tal especialização teve o 
nefasto efeito de afastar ainda mais o juiz do processo de conhecimento do mundo real da pena, tornando-se cada vez mais conhecedor do crime (conduta típica) e desconhecedor da realidade.

Nem se argumenta que o juiz do processo de conhecimento não visita os estabelecimentos penais, nem mesmo as cadeias que, pela Lei de Execução Penal, mantém os presos relacionados aos seus processos. O que não se compreende é que este juiz não saiba que a prisão causa sim mortes e castigos corporais de toda ordem. O certo, todavia, é que com a especialização da execução penal e instituições das respectivas varas, cada vez mais o juiz que julga se vê longe da realidade prisional e aumenta a conduta de lavar as mãos para a sanção executada no dia a dia.

Peculiar a situação do juiz da execução penal, que nunca pode atenuar a pena aquém dos limites estabelecidos por lei, mas não raramente agrava a sanção muito acima dos prazos e parâmetros estipulados na legislação. Se a especialização da execução penal pensou um juiz melhor preparado, com conhecimentos em outras disciplinas que não só o direito, um juiz que pudesse ser imparcial numa nova fase do processo, fez bem, mas em nenhum momento demonstrou acreditar na função preventivo especial desse magistrado, pelo contrário, ele é mais um instrumento encarcerador.

Como bem ressaltou Foucault, no vácuo da esfera penitenciária formaram-se as disciplinas, os micropoderes e "um filho bastardo, e entretanto disforme: o juiz da aplicação das penas" (1998, p. 208). Assim Foucault descreve o juiz da execução penal ${ }^{105}$, com sua verve irônica ou, melhor dizendo, nietzschiana. Um juiz que veio para lutar por espaço punitivo no labirinto que é a prisão.

Mas é possível retorquir dizendo que a lei previu poder o juiz da execução penal tomar medidas para o adequado funcionamento do estabelecimento penal (art. 66, VII, da LEP), contudo, que medidas seriam essas, se nenhuma vem especificada na lei? O juiz da execução, com seu poder de fiscalização, não tem qualquer poder coercitivo para obrigar o Estado a fazer a pena de prisão menos desumana. O trabalho desse juiz se resume em elaborar relatórios que são distribuídos e bem guardados nas gavetas das inúmeras autoridades superiores.

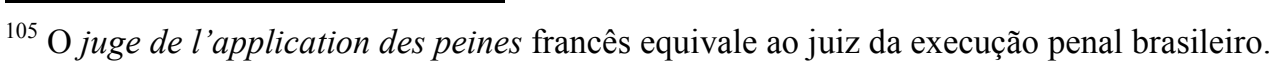


Mas existe a possibilidade de interdição do estabelecimento penal. Correto, existe, mas interditado o estabelecimento penal o juiz deverá obviamente soltar os presos que estão ali recolhidos, independentemente da pena ou do processo pelo qual estão respondendo. Sim, porque interditar um estabelecimento penal para mandar os presos para outro, agravando a superlotação e as condições de vida de todos, não é "a melhor solução" (MARCÃO, 2007, p. 75). Daí se conclui, pelo exemplo que temos de juízes que são punidos quando tomam a medida correta de soltura de $\operatorname{presos}^{106}$, que o juiz da execução penal não pode nada.

Corrigindo, o que pode o juiz da execução penal é evitar o pior, ser um vigia do caos, salvar um ou outro preso de uma tortura evidente, tirá-lo de um buraco escuro, tentar apurar responsabilidades no dissimulado meio carcerário, procedimento que ganhará o mesmo destino dos relatórios de visitas. No mais, com as estruturas que têm as varas de execuções penais, o juiz estará ajudando, se conceder o direito dos presos com o mínimo retardo possível. Convenhamos, se o sistema punitivo funcionasse a ponto de justificar a aplicação de tanta pena de prisão, não precisaríamos de um juiz desses, um fiscal do absurdo.

Isso sem levar em conta que a maioria dos juízes das varas de execuções penais estão sempre de passagem. Quando demonstram interesse pela verdadeira realização do mínimo possível de justiça no meio carcerário, logo se desestimulam com a falta de apoio, mas normalmente são juízes designados por critérios políticos, "para "cuidar do assunto" (WEIS, 2001, p. 3).

O caráter descartável do juiz da execução é agravado com os já conhecidos mutirões do Conselho Nacional de Justiça, com mais juízes designados para cuidar do assunto. A ausência de estrutura das varas de execuções penais normalmente termina em um relatório dos membros do $\mathrm{CNJ}$ sem maiores consequências, apenas alguns presos são realmente postos em

\footnotetext{
${ }^{106}$ A situação mais conhecida foi a do magistrado mineiro que, na Comarca de Contagem, determinou a soltura de presos que estavam em "condições desumanas e insalubres", tendo sido punido imediatamente, inclusive com remoção compulsória (disponível em: <www1.folha.uol.com.br/>. Acesso em: 21 jan 2011). Ela de Castilho lembra ainda a inúmera quantidade de afastamento de juízes da execução penal de suas funções quando estes dão início a procedimentos de investigação sobre irregularidades no sistema prisional (1988)
} 
liberdade $^{107}$, mas a execução penal continua abandonada, o juiz local desprestigiado e os demais presos aguardando um novo mutirão.

Para completar a delicada posição do magistrado das execuções penais, enquanto a comunidade carcerária sofre com a burocracia e as más condições de trabalho na vara de execuções, motivos de retardo na concessão de direitos, a mídia e a sociedade encaram o juiz da execução penal antipaticamente como aquele que solta criminosos. Ferindo inclusive o imaginário coletivo, no qual a figura do juiz é sempre a daquele que priva da liberdade, aquele que prende, o juiz das execuções acaba se tornando uma figura ambígua (CALVANESE, $2004)^{108}$.

Como bem constatou Howard Becker (2008), o juiz também pode ser um outsider, quando as regras impostas não são percebidas como legítimas e, assim, o juiz da execução penal é um outsider não só para a população carcerária, mas da mesma forma para a sociedade e no interior do próprio judiciário. Dentro da instituição a que pertence, o juiz da execução tem dificuldade em ser compreendido: "sempre sob a suspeita de desfazer o veredicto do juiz, portanto, enfraquecer a autoridade da justiça, é, além disso, olhado com reserva pelos magistrados" (BORDIEU, 2011, p. 243).

Outra questão que parece relevante é o abandono quase que por completo, no Brasil, da expressão direito penitenciário. Digo expressão porque como disciplina nas universidades, como tema de trabalhos acadêmicos ou como matéria de concursos jurídicos, o direito penitenciário já nem mais é citado ${ }^{109}$. A nomenclatura execução penal parece ter sobressaído, muito embora inclusive esta, não tenha muita relevância para o direito, sendo não raramente um capítulo do processo penal.

Antes da Lei de Execução Penal em vigor, a maioria das codificações eram denominadas códigos penitenciários. Pelo menos até 1963, quando o eminente Roberto Lyra

${ }^{107}$ Em estatística sobre mutirão do CNJ no Rio Grande do Sul há a informação de que este foi responsável por um impacto de apenas $0,38 \%$ sobre a população carcerária, em atividades com a duração de trinta dias. Disponível em: www.conjur.com.br. Acesso em: 15 jun 2011.

${ }^{108}$ Ernesto Calvanesse, em seu trabalho Pena riabilitativa e mass-media, faz uma vasta pesquisa nos periódicos italianos para concluir que a comunicação sobre as funções do juiz da execução penal (Magistratura di Sorveglianza, na Itália) em $71,12 \%$ dos casos tem conotação negativa.

${ }^{109}$ A desconsideração pelo direito penitenciário é tanta, que no verbete direito penitenciário, do Dicionário Jurídico Brasileiro, da Editora Del Rey, consta como sinônimo simplesmente: "Direito Tributário" (SANTOS, 2001, p. 82). 
foi convidado para elaborar mais um anteprojeto. Nesta ocasião o já consagrado professor respondeu por carta ao ministro João Mangabeira, informando da repugnância por um código penitenciário, não só "pela denominação, mas também pelo conteúdo. Combato o intolerável anacronismo e tudo que ele representa. A penitência cabe à sociedade" (LYRA, 1974-b, p. 74) e em seguida indicou sua preferência por código das execuções penais.

Direito penitenciário e direito da execução penal podem ser sinônimos para alguns, mas há outros autores que indicam a execução penal como mais abrangente, enquanto o direito penitenciário seria somente relacionado às relações no cárcere (MIRABETE, 1997). No sentido oposto, direito penitenciário pode ser mais amplo que a execução penal, incluindo além das normas relacionadas à prisão, as restrições de direitos e de liberdade aplicadas pelo direito penal, restando para a execução somente o aspecto processual (MIOTTO, 1992).

O cientista delimita o objeto de sua ciência de acordo com suas preferências, contudo não se duvida que a Lei de Execução Penal brasileira pretendeu abranger o processo de execução da pena e todos os direitos inerentes à vida carcerária em uma só codificação, empobrecendo como consequência do próprio nome da lei, todos os debates e discussões que antes se travavam em nome de um direito penitenciário.

Hoje em dia não se discute o processo sancionador no interior do cárcere, a assistência penitenciária, quase totalmente inexistente, não é objeto de debate no sentido de se encontrar melhores formas de efetivá-la, a defensoria pública fica quando muito limitada ao processo executivo que tramita em juízo, os direitos dos presos são tidos como benefício pela maioria das pessoas e até por operadores do direito que, nesta área, mais do que em qualquer outra, são menos operadores do que operados, "serviçais do direito" (SÁ, 2010, p. 42), ou seja, incapazes de refletir sobre o ordenamento jurídico.

Zaffaroni e Nilo Batista têm a denominação direito penitenciário como "não recomendável, pois parece reduzir-se à pena de prisão e, além disso, remonta às penitencias religiosas da Idade Média” (2006, p. 296), contudo, não vemos dessa forma: o direito penitenciário não traduz mais a ideia de penitência, mas sim a de direito do preso, direito do cidadão no sistema penitenciário. Por outro lado, não vemos nada demais em possuirmos um 
direito que se reduza à pena de prisão, aliás há necessidade de serem enfatizados os direitos inerentes à pena de prisão, o que o direito da execução não tem permitido.

Antes direito penitenciário hoje direito de execução penal e a realidade do sistema punitivo pouco mudou, portanto a reassunção da antiga designação pode não significar muito, mas ao menos permitirá um maior exame jurídico ou científico das situações específicas do cárcere. A nosso ver o abandono do direito penitenciário no Brasil se deu prematuramente e abriu espaço para um direito da execução penal que na prática não é direito inerente à prisão, parecendo mais um direito do cartório ou da secretaria do juízo do que um direito relacionado à situação de encarceramento.

Talvez direito penitenciário desse mais a noção de que no cárcere há sujeitos de direito e que a única diferença destes para o cidadão livre é aqueles estarem vivendo dentro de uma instituição pública. Por certo que toda convivência deve observar determinado número de regras, por isso há deveres no interior dessas instituições, mas ao preso devem ser garantidos todos os direitos não atingidos pela lei ou pela sentença (art. $3^{\circ}$ da LEP).

E aí se chega a outro corolário do princípio da legalidade, o "nulla poena sine iudicio" (TUCCI, 1993, p. 71) que indica não bastar a pena clara e taxativa na lei, mas deve ainda ser objeto de um processo e resultar de uma sentença que também observe um estrito determinismo ao individualizar a sanção.

Pelas situações em que se vê o preso, seus direitos no interior do cárcere são de caráter material e não processual. A tendência em considerar a execução penal como um mero processo, esconde o ser humano que está por trás, como objeto, mas que devia ser sujeito desse procedimento. O processo de execução penal é meio e não fỉm, e deve servir para a garantia dos direitos inerentes à vida carcerária.

A mudança de título da legislação, de penitenciária para execução penal, não mudou a realidade, como o mestre Roberto Lyra deveria ter suposto, e, a julgar por suas próprias palavras, a execução penal continua na mesma em questão de legalidade:

Não se defende a sociedade sacrificando a dignidade humana e oficializando a mentira anárquica de uma execução que não executa ou, pior, executa contra a lei e a sentença. Ao invés de tudo para alguns e nada para o resto, procuremos garantir o 
legal e humano para todos. Não se defende a sociedade com sistemas que, em regra, só interrompem o abandono para o castigo (1974-b, p. 76).

A dificuldade de implementar o princípio da legalidade na execução penal é histórica. Diferentemente da dogmática do crime, que desde Beccaria só fortaleceu os conceitos e a abrangência da tipicidade, a pena executada não era assunto dogmático. Bastava a divergência sobre a finalidade da pena, "o conteúdo e limites dos direitos dos presos derivavam desse fim, utilizado, ao mesmo tempo como fundamento e fim, em confusão metodológica, possibilitando uma ampla sujeição do recluso" (LOPES, 1994, p. 142).

Ocorre que na batalha entre as escolas clássica e de defesa social, cada uma ganhou um território. Antes da condenação, (quase) todos os direitos garantidos, mas depois da sentença, um vácuo jurídico. A escola clássica não deixou os princípios de defesa social invadirem o processo penal, mas, em compensação, após a condenação, deixou o campo livre. A sentença passou a ser o divisor de águas da condição de cidadão do ser humano.

\subsection{A IMPORTÂNCIA DA CRÍTICA À JURISPRUDÊNCIA}

O valor do estudo da jurisprudência pode ser demonstrado por diversas formas, mas o que hoje em dia parece mais relevante é a possibilidade de se proporcionar uma aproximação entre a prática jurisprudencial e a Academia. A distância que uma vem tomando da outra é notoriamente prejudicial para ambas.

A prática forense sem uma crítica orientada e refletida resume-se em um emaranhado de sentimentos absolutamente distanciado do que se pode considerar como ciência. Ao mesmo tempo, a Academia, se fechada em um dogmatismo pseudocientífico, sem pretender uma influência direta no exercício de fato do direito, estará fadada à estagnação e à perda gradativa de sua legitimidade.

Chaves Camargo indica algumas circunstâncias que parecem agravar esse distanciamento, favorecendo uma "jurisprudência de interesses", afastada da realidade social: a crença em um sistema perfeito, que por si só possa resolver todos os problemas apresentados na ciência jurídica; um ensino jurídico pautado pela tecnização, carente de uma formação doutrinária e filosófica ampla que possa contribuir para "uma postura crítica diante dos 
institutos jurídicos"; uma jurisprudência que se pretende fixa, vinculante, sem respeitar a complexidade e a mutabilidade das relações sociais; e a "pacificidade dos manuais de direito, sempre preocupados em afirmativas categóricas”, também obstaculizadoras da crítica (2001, p. 76-77-78).

Mais grave do que o distanciamento entre jurisprudência e Academia, essa impermeabilidade de ambas causa um problema muito mais sério que é a perda de contato com a realidade. Fechadas em métodos ou dogmas acabam não percebendo as verdades que a vida apresenta. Aliás, a prática forense e as construções dogmáticas, só por serem preconcebidas, abstraem certos aspectos do mundo e ignoram outros, admitem certas premissas e negam outras, aceitam algumas formas de investigação e vedam outras.

Uma verdadeira ciência em uma sociedade que já não mais acredita na razão iluminista, deve ter no mínimo a humildade de reconhecer seus erros e suas debilidades, pois só assim poderá continuar sendo instrumento válido e útil para as relações sociais.

A antiga ideia de que o processo decisório era objetivo, derivado de uma racionalidade científica, não se sustenta mais. No caso, a aparência de objetividade só tem servido para encobrir uma grande quantidade de ideologia ou de preconceitos, situação em que a construção jurisprudencial produzida em série acaba servindo como suporte de manutenção.

Em virtude da lei do menor esforço e também para assegurar aos advogados o êxito e aos juízes inferiores a manutenção de suas sentenças, do que muitos se vangloriam, preferem, causídicos e magistrados, às exposições sistemáticas de doutrina jurídica os repositórios de jurisprudência. Basta a consulta rápida a um índice alfabético para ficar um caso liquidado, com as razões na aparência documentadas cientificamente. Por isso, os repertórios de decisões em resumo, simples compilações, obtêm esplêndido êxito de livraria (MAXIMILIANO, 1941, p. 223).

Em um judiciário democrático a jurisprudência deveria refletir o debate de diversas questões que afligem a população e não somente reproduzir decisões superiores, todavia a advertência do ex-ministro da Corte Suprema brasileira parece cada dia mais atual. Mas não é da lei do menor esforço, acima referida e também traduzível como preguiça, que se quer falar, mas sim do que pode ficar encoberto com o uso ingênuo da jurisprudência como fonte de decidir. 
Independentemente da corrente adotada no que se refere ao valor do aresto de um tribunal, o uso da jurisprudência tem servido como reforço para as decisões de primeira instância. Não importa que na teoria e na Constituição Federal o magistrado seja independente, a prática dos tribunais é verticalizada e mesmo hierarquizada. A bajulação, as arbitrárias convocações de juízes, os processos administrativos kafkanianos, a conduta administrativa dos tribunais como um todo cria uma situação de dependência dos juízes que só reforça a sua subserviência em relação a qualquer decisão superior.

A jurisprudência, o usus fori, pode ser considerado desde fonte de direito até simples manifestação do judiciário frente a um caso concreto, passando pelos que consideram jurisprudência somente as decisões pacíficas (FRANÇA, 2009), todavia, na prática, qualquer decisão de tribunal superior sempre poderá servir de reforço para uma sentença já precária de fundamentação. Os equívocos se reproduzem de acórdãos em sentenças sem qualquer debate, pois a autoridade da jurisprudência se encaixa na estrutura de um judiciário verticalizado.

Os juízes sofrem uma espécie de identificação com a autoridade superior, e se tornam até mais rigorosos do que esta. O juiz que almeja estar nos mais altos graus do judiciário "começa por desejar assemelhar-se ao seu superior, até que, gradualmente, a constante dependência material acaba transformando toda a sua pessoa" (REICH, 2001, p. 44) $)^{110}$ (Grifei). E, nesse contexto, a jurisprudência se transmuda em ordem e a postura, os sentimentos, preconceitos e equívocos que estão por trás dessa ordem, chegam à primeira instância potencializados. O juiz não interpreta a jurisprudência do tribunal, ele termina interpretando a vontade da instância superior para fazer dela a sua própria, reproduzindo a subserviência dos corredores dos tribunais.

Nesse aspecto é que se demonstra importante a crítica jurisprudencial deste trabalho. Embora o termo ressocialização seja somente um entre inúmeros outros que podem encobrir e revelar ao mesmo tempo o caráter de reprodução de sentimentos negativos no judiciário, o uso contínuo deste termo só demonstra o descaso para com o sentido comunicativo que poderia ter

\footnotetext{
${ }^{110}$ Wilhelm Reich indica outra característica da identificação que muito se presencia nos tribunais, quando diz que o funcionário público, dependente da autoridade superior, "desenvolve um comportamento competitivo entre os colegas, que é contrário ao desenvolvimento da solidariedade" (2001, p. 44).
} 
a decisão prolatada. E, desta forma, sendo reiterado, aumenta a possibilidade de uso, ou imitação, pelas demais instâncias ou órgãos.

Lídia de Almeida Prado (2003) informa que vários autores já abordaram o fato de que juízes antecipam mentalmente suas decisões e depois procuram a norma que pode servir de fundamento. Desde Karl Llewellyn, passando por Recaséns Siches, Joaquim Dualde, Jerome Frank, Miguel Reale e Renato Nalini ${ }^{111}$, há referências à influência de aspectos subjetivos prévios à atividade decisória.

Tal antecipação mental é natural, inerente aos seres humanos. Ao juiz caberia, mesmo intimamente, a procura da decisão mais justa ao caso concreto, com a capacidade de colocarse na posição do outro (REALE, 1994), mas não é o que ocorre em muitos casos, servindo o arcabouço doutrinário e jurisprudencial para encobrir sentimentos que beiram a raia do ódio.

As manifestações jurisprudenciais que se pretende analisar neste trabalho são exemplos do uso da argumentação jurídica para encobrir sentimentos que não deveriam estar presentes na decisão judicial, porque resultam no abandono de qualquer verificação da realidade. $\mathrm{O}$ uso do termo ressocialização como argumento para agravar a pena privativa de liberdade é denunciador desse descaso em que se tornou a prática judiciária.

Vê-se que diante de tudo quanto dissemos a proposta aqui apresentada é modesta. Muitas decisões podem encobrir sentimentos negativos do julgador e serem bem fundamentadas, com aparência da mais estrita legalidade; todavia quando se impõe uma pena maior ou se nega um direito a um preso, usando como desculpa o fato de que assim se está procedendo para a sua ressocialização, a falta de bom senso é tão grande que torna patente a fragilidade de decisão.

Se, como vimos, ressocialização é um sentimento de mudança do outro, de correção do outro pelo mal pena, que acompanha a atividade punitiva desde os seus primórdios, fazendo parte da natureza do ser humano, o que fazem essas decisões é somente encobrir esse sentimento. O paradoxo está em constatar que ao mesmo tempo em que o uso do termo

\footnotetext{
${ }^{111}$ Incluindo-se pela representatividade de sua obra, o professor de Gênova Riccardo Guastini (2005). Warat e Pêpe informam também que alguns autores chegam a afirmar que "as normas gerais são um conjunto de enunciados metafísicos que cumprem somente a função retórica de justificar as decisões dos juízes" (1996, p. 44).
} 
ressocialização, para encarcerar, é uma mentira evidente e forte, por isso mesmo acaba sendo uma forma bem direta de demonstrar o caráter mais negro da atividade jurisdicional: puro exercício arbitrário do poder.

Nas lições de Guastini (2005) a análise jurisprudencial pode ser feita sob os aspectos normativo e pragmático; no primeiro há uma busca da justificação interna de cada decisão e, no segundo, um estudo das consequências do pronunciamento judicial. Nossa atividade se aproximará mais deste segundo tipo de estudo. Quando se faz uma demonstração de decisões jurídicas que usam um fundamento falso, ideológico, não se faz simplesmente uma crítica dogmática. Por tudo quanto foi visto, uma demonstração desse tipo indica consequências que atingem a comunicação que deveria estar presente na prática judicial e na punição em si, além dos resultados humanos negativos na sociedade e no cidadão punido.

No final das contas demonstra-se, com esse tipo de estudo, que "é 'cega' nesse sentido a decisão que é adotada sem representar-se primeiramente os seus efeitos práticos previsíveis" (GUASTINI, op. cit, p. 249).

Em outro sentido, considerando-se que a "norma é produzida, pelo intérprete, não apenas a partir de elementos do texto normativo (mundo do dever-ser), mas a partir de elementos do caso ao qual será ela aplicada, isto é, a partir de dados da realidade (mundo do ser)” (GRAU, 2005, p. 35), este trabalho terá característica de estudo normativo. Pois quando na produção da norma, partindo da consideração acima, o intérprete forja o mundo do deverser com o argumento de ressocialização, ele está deliberadamente falseando concepções, reconhecendo como dado da realidade (mundo do ser) esta possibilidade de se ressocializar mediante o encarceramento.

Estando os dois extremos da hermenêutica jurisprudencial situados entre a que é considerada simplesmente dedutiva e formalista, e aquela tida como ativismo judicial, orientada para a realização de valores materiais (YEPES, 1997), as circunstâncias da realidade da pena de prisão são mais do que estimulantes e até indicativas de uma atividade jurisdicional que realmente combata a violação constante de direitos humanos que é o sistema punitivo. Todavia não foi o que pretendemos neste trabalho e a nossa proposta é muito menos pretensiosa, resumindo-se a erradicar da interpretação judicial a consideração da 
ressocialização, substituindo-a, como veremos, pelo respeito à dignidade humana e ao princípio da legalidade.

Sendo ressocialização um termo vago, sem conteúdo jurídico, não pode compor nem a finalidade da pena abstratamente considerada, nem a aplicação da pena imposta na sentença, pois momento do corolário nulla poena sine iudicio, não podendo muito menos servir de parâmetro para o julgamento dos direitos inerentes à execução penal, tudo isso sob pena de se estar ferindo de morte a certeza necessária do princípio da legalidade.

Ainda que fosse possível uma interpretação dedutiva e lógica da lei, desconsiderando a condição humana do julgador e a utopia linguística de uma redação legal precisa (SÜB, 2000), não se conceberia que um argumento como o ressocializador, sobrevivesse como instrumento válido de hermenêutica, uma vez que, na tentativa do juiz de ser o mais subordinado à lei possível, este logo esbarraria nas disposições do Código Penal e da Lei de Execuções Penais, que deferem inúmeros direitos não efetivados. A rigor, um juiz que fosse extremante legalista, e procurasse julgar exatamente como está na lei, nunca deveria aplicar uma pena privativa de liberdade, porque esta não existe como está na lei.

Por sinal, nem mesmo na legislação há o termo ressocialização, posto que a Lei de Execução Penal, ao se referir ao fim da execução, diz que esta se propõe à "harmônica integração social do condenado" (art. $1^{\circ}$ ) e o Código Penal faz referência somente, como já referido, à repressão e prevenção do crime. Portanto o próprio fim ressocializador da pena, ao menos no Brasil, deriva de uma interpretação e não está na letra clara da lei.

Supondo que fosse uma palavra existente na legislação ou mesmo um princípio devidamente expresso, como é em alguns países, a exemplo da Espanha e da Itália (BARATTA, 2006), a ressocialização não resistiria ao primeiro confronto com sua impossibilidade prática ou com a incompatibilidade com os princípios da legalidade e da dignidade da pessoa humana. No mais, se resistisse a tal conflito, a interpretação histórica da palavra já a teria tirado de circulação. Para tanto, basta perceber que a escola denominada Nova Defesa Social introduziu o argumento ressocializador com o intuito humanizador, há muito fracassado. 
Nossa crítica neste trabalho nem irá discutir a ausência do termo ressocialização na legislação e avaliaremos as decisões considerando plausível interpretar a harmônica integração social do condenado da LEP como ressocialização, embora pareçam hoje em dia coisas bem distantes, seja porque a integração social do condenado não se dará no meio social de quem lhe está impondo valores, seja porque a própria imposição de valores se tornaria inviável em um Estado democrático. Ademais, a LEP fala de "proporcionar condições à harmônica integração social" (art. $1^{\circ}$ ), portanto algo que não pode ser imposto de cima para baixo como é a visão doutrinária e jurisprudencial do tido por ressocialização. De qualquer forma, sobre a atividade prática da execução penal falaremos no último capítulo.

Em suma, o ideal ressocializador não pode de forma alguma servir para prejudicar o cidadão, por ser vago e não cumprir os requisitos mínimos do princípio da legalidade. Assim, partindo dessa conclusão, passamos a examinar alguns momentos processuais e incidentes na execução penal ${ }^{112}$ em que o termo ressocialização vem em prejuízo do réu ou do apenado.

A lembrança de Ela Wiecko de Castilho de que "a escassez de acórdãos patenteia também o escasso questionamento da legalidade na execução penal" (1988, p.12) deveria ser reformulada, porque possuímos uma crescente produção de decisões, contudo é justamente a jurisprudência que vem patentear o descaso no questionamento da legalidade na execução penal. Quanto à advertência de falta de sistematização doutrinária sobre a execução da pena, feita pela mesma autora, continua incrivelmente atual.

Inicialmente não iríamos incluir questões do processo de conhecimento, mas até para melhor evidenciar o ruído interpretativo que tem causado a palavra ressocialização, tornando evidente a violação ao princípio da legalidade, e igualmente para não ficarmos somente na já tão abandonada execução penal, optamos para tratar inicialmente da individualização da pena na sentença.

\footnotetext{
${ }^{112}$ É comum o uso do termo incidente de execução ao invés de incidente na execução, mas salutar, pois de acordo com a nomenclatura legal (arts. 180 e segts. da LEP), a lição de Sérgio Pitombo de que "são incidentes na execução os atos e fatos que lhe importam andamento, como a progressão e regressão, nos regimes; a remissão da pena; e o livramento condicional" (2011, p. 16), enquanto incidente de execução seriam somente os incidentes de excesso ou desvio, anistia e indulto, além do incidente de cessação de periculosidade, pois incidentes que correspondem "a processo autônomo, que se insere no âmbito de outro já em curso" (2011, p. 4).
} 
Todavia, antes de passar a transcrever decisões jurisprudenciais neste trabalho é salutar um esclarecimento. Os acórdãos publicados na rede de computadores, internet, violam frontalmente a lei quando permitem o acesso a qualquer um dos nomes das partes em processo criminal. A Lei de Execução Penal, em seu art. 202, é clara ao determinar que "cumprida ou extinta a pena, não constarão da folha corrida, atestados ou certidões fornecidas por autoridade policial, auxiliares da Justiça, qualquer notícia ou referência à condenação, salvo para instruir processo pela prática de nova infração penal", portanto a exposição dos sentenciados como condenados na internet viola tal dispositivo.

A lei não poderia ser mais direta. Em nome da preservação da intimidade de cada um e até da necessidade de permitir a um ex-condenado uma vida normal, vedou qualquer divulgação da sentença condenatória. Pode-se dizer mesmo que tal regramento se deu pela crença da legislação na ressocialização do apenado, mas tal dispositivo está a serviço igualmente da dignidade da pessoa humana, visto que uma pessoa que tem uma condenação exposta dessa forma, ad aeternum, estará sempre sujeita a não conseguir emprego ou a ser demitida do trabalho que por ventura venha conseguir.

Certo que as decisões são públicas, mas a publicidade tem a função de trazer transparência à administração da justiça. É mais uma garantia do cidadão frente ao Estado, garantia que não pode se virar contra o seu próprio titular. O que a lei pretendeu não foi vedar a publicidade da decisão, esta existiu no momento de sua publicação, mas não pode mais permanecer em documentos, virtuais ou não, emitidos ou disponibilizados sob a chancela do poder público.

A publicação das decisões e entendimentos dos tribunais é de suma importância, mas possuímos tecnologia suficiente para que os nomes dos condenados não permaneçam na tela dos computadores de todo mundo. "É preciso tratar a publicidade com as cautelas que o nosso tempo exige" (PITOMBO, 2001-a, p. 112). Por isso, obviamente, omitimos os nomes dos sentenciados neste trabalho, mas fica aqui a advertência de mais essa ilegalidade que viola garantias do cidadão e demonstra o quanto o ideal de ressocialização é esquecido de acordo com a conveniência da ocasião. 


\subsection{A INDIVIDUALIZAÇÃO JUDICIAL DA PENA E A RESSOCIALIZAÇÃO}

A individualização da pena, princípio inscrito no inciso XLVI do art. $5^{\circ}$ da Constituição Federal, se dá em três fases: a legislativa, a judicial e a executória (FRANCO, 1994; PITOMBO, 1999 ${ }^{113}$; BARROS, 2001; PASCHOAL, 2003); e cada etapa individualizadora da sanção penal deve igualmente cumprir o postulado básico do nullum crimen, nulla poena sine lege, igualmente princípio constitucional.

Em resumo: o legislador deve, ao tipificar uma conduta, estabelecer os limites da pena de forma abstrata; após, o magistrado, ao examinar o fato que se enquadra à conduta típica, estabelecerá a pena concreta aplicada ao caso; em seguida, na execução penal, o juiz competente zelará para que a pena aplicada seja executada de acordo com as condições e as peculiaridades de cada condenado.

O que veremos a seguir é o ideal de ressocialização surgindo como ingrediente nessa equação, enfraquecendo o princípio da legalidade porque, ao invés de trazer certeza, aumenta o grau de arbítrio na aplicação da pena.

\subsubsection{Individualização e fixação do regime inicial de pena}

O critério adotado pelo Código Penal, após a reforma de 1984, para a individualização da pena na fase judicial, foi o trifásico. Critério que privilegia o princípio da legalidade, diminuindo o grau de incerteza na aplicação da pena que poderia derivar do livre convencimento permitido ao magistrado nesta fase.

A legalidade, no caso, sai fortalecida pela obrigação do magistrado de fundamentar cada fase que acarretará a aplicação da pena. "Quanto maior o conteúdo discricionário da decisão mais necessária é a sua motivação, especialmente para que se possa aquilatar se o juiz usou bem ou mal a liberdade que lhe foi conferida" (SHECAIRA, 2010, p. 16). Os limites da sanção penal não serão, então, limites arbitrários para o magistrado, ou seja, este não pode

\footnotetext{
${ }^{113}$ Para Pitombo a individualização da pena "abriga duas espécies: legislativa e judicial. A última admite duas subespécies: cognitiva e executória" (1999, p. 150). Ou seja, para o autor, a individualização resultado do processo de conhecimento e a individualização que ocorre na execução da pena fariam parte da mesma espécie, a individualização judicial da pena.
} 
escolher a pena que entender cabível dentro dos limites mínimo e máximo da sanção, visto que a aproximação do máximo está estritamente condicionada à lei e à motivação na sentença.

Discricionariedade sempre haverá na avaliação de qualquer conduta, sendo impossível ao ordenamento jurídico compartimentar circunstâncias que tornem a atividade de magistrado objetiva. A propósito, como já advertia Concepción Arenal, quanto maior for o número de aspectos de uma conduta a ser estudado, "a probabilidade de erro é maior""114 (1895-a, p. 137). Por ser a conduta humana, como o ser humano, dotada de uma complexidade infinita, esta que se soma à complexidade do julgador, somente a fundamentação aproximará o julgamento da legalidade.

A limitação do magistrado no momento de aplicação da pena deve se contrapor a uma ampla liberdade para fundamentar, pois só assim será possível averiguar os verdadeiros motores da prática judicial. Manifestações lacônicas e rápidas na sentença servem somente para um formal preenchimento do princípio da legalidade, mas tendem a encobrir o verdadeiro sentimento do ser humano juiz sobre a conduta de quem está sendo julgado.

A motivação, cumpre lembrar, importante para o que defendemos neste trabalho, deve servir como eficiente meio de comunicação, pois na lição de Davi Tangerino, só se dará se coincidir com "outros sistemas de motivação do comportamento humano em sociedade" (2011, p. 103). Assim, o idealismo dos antigos dogmas jurídicos, há muito fracassado diante do confronto com a realidade, não poderá nunca servir de motivação, pois suas essência e objetivos cresceram em descrédito no meio social.

Não trataremos especificamente da fixação do quantum de pena aplicável, mas sim do regime inicial de cumprimento da pena privativa de liberdade, o qual, por indicar a qualidade da pena, deve ser devidamente fundamentado. Não se deve esquecer que os regimes da pena privativa de liberdade estão diretamente ligados ou constituem a própria qualidade da pena em questão, o que quer dizer que a força e a intensidade dessa pena, o seu sofrimento, serão regulados pelo regime aplicado. Então, tão essencial quanto a fundamentação da quantidade, é a fundamentação da qualidade da pena privativa de liberdade.

\footnotetext{
${ }^{114}$ No original: "la conducta es un compuesto del que pueden apreciarse algunos ó todos los componentes, y á medida que se necesitan estudiar más, la probabilidad de no acertar es mayor” (ARENAL, 1895-a, p. 137).
} 
O critério trifásico inicia com o estabelecimento da pena base, na forma do art. 59 do Código Penal, observadas as circunstâncias devidamente estabelecidas pela lei nesse dispositivo legal. Após fixada a pena, com a consideração das circunstâncias atenuantes e agravantes, além das causas de aumento e diminuição da pena, deve o magistrado estabelecer o regime inicial de cumprimento da pena privativa de liberdade, obviamente tendo sido esta a pena aplicada.

Para a fixação do regime inicial o magistrado deve levar em conta as mesmas circunstâncias do art. 59 do Código Penal ${ }^{115}$, seguindo os parâmetros do art. 33 do mesmo código. Neste artigo, o legislador foi bem claro ao estabelecer que o condenado a pena superior a 8 anos deveria iniciar o cumprimento da reprimenda em regime fechado (letra a, do $\S 2^{\circ}$, do art. 33 do $\mathrm{CPB}$ ); enquanto o condenado não reincidente, cuja pena não excedesse 8 anos e fosse superior a 4 anos, poderia iniciar em regime semiaberto (letra $b$, do $\S 2^{\circ}$, do art. 33 do $\mathrm{CPB}$ ); e já o condenado a pena que não excedesse a 4 anos, não reincidente, poderia iniciar o cumprimento da pena em regime aberto (letra c, do $\S 2^{\circ}$, do art. 33 do CPB).

A decisão que veremos a seguir usou o argumento ressocializador para fixar um regime inicial superior ao que o sentenciado tinha direito:

Crime contra o patrimônio. Artigo 157, $\S 2^{\circ}$, incisos I e II, do Código Penal. Pena: 7 anos e 6 meses de reclusão, regime fechado, e 90 dias-multa, valor unitário. (...) A pena base deve ser reduzida ao patamar mínimo, pois circunstâncias judiciais do art. 59 do Código Penal são normais ao tipo e não prejudicam o apelante. Também merece abrandamento a elevação da pena na terceira etapa do critério trifásico por força das duas majorantes, sendo justa para o caso a incidência da fração $3 / 8$. O regime prisional fechado foi corretamente fixado, ressaltando-se que eram três os roubadores, sendo que dois deles ameaçaram as vítimas com as facas que portavam, o que demonstra a periculosidade do réu, devendo ser observado em penitenciária de segurança máxima seu processo de ressocialização.(...) Apelo parcialmente provido para, mantendo a condenação do réu por violação ao artigo $157, \S 2^{\circ}$, incisos I e II, do Código Penal, fixar a resposta penal em 5 anos e 6 meses de reclusão, regime fechado, e 13 dias-multa, no valor unitário de 1/30 do salário mínimo, mantidas inalteradas as demais cláusulas da sentença (TJRJ, $8^{\mathrm{a}}$ Câm. Crim., Ap. n. 0089004-31.2009.8.19.0001, Des. Rel. Marcus Quaresma Ferraz, v. unânime, j. em 15/09/10, p. em 16/09/2010) (Grifei).

Apesar da possibilidade, de acordo com a pena aplicada e seguindo os parâmetros do art. 33 do Código Penal, de se impor o regime semiaberto, a decisão trazida à colação

\footnotetext{
${ }^{115} \mathrm{O}$ código repete em diversas oportunidades os critérios para aplicação da pena por questão até mesmo didática (REALE JR, 1983), procurando mais do que evitar uma ampla discricionariedade, mas orientar o magistrado nessa difícil tarefa.
} 
entendeu pela manutenção do regime fechado, em penitenciária de segurança máxima, para fins de ressocialização, como se esta realmente se efetivasse, como se existisse na realidade um processo de ressocialização.

Seria desnecessário tecer maiores comentários sobre tal argumento, todavia é bom ressaltar que a decisão em referência não passa nem pelo crivo de um exame frio e técnico. Ao crime cometido, objeto da decisão em comento, poderia ter sido aplicado qualquer um dos regimes de cumprimento de pena, contudo a decisão deveria vir satisfatoriamente fundamentada.

Em verdade, não estamos de frente a uma discricionariedade livre, mas sim a uma discricionariedade vinculada, preservado o princípio da legalidade, a fim de que a liberdade do magistrado na aplicação da pena não descambe para a arbitrariedade (COSTA JR, 2008). Quanto ao assunto há inclusive súmula do STF no sentido de que "a imposição do regime de cumprimento mais severo do que a pena aplicada permitir exige motivação idônea" (Súmula 719).

Ocorre que a decisão anteriormente citada usou como motivação para a aplicação do regime mais grave a periculosidade do agente e a importância do regime fechado para a ressocialização do mesmo, muito embora tenha considerado a conduta pouco censurável na ocasião de aplicar a pena base, tanto que estabeleceu a pena mínima.

A grande incoerência, então, está no fato de que, devendo-se adotar o mesmo critério para a fixação da pena base e para o estabelecimento do regime inicial, os magistrados do Tribunal de Justiça do Rio de Janeiro entenderam por seguir parâmetros diferentes, com a pena base fixada no mínimo e o regime estabelecido no máximo, tudo em nome da tão enfraquecida ideia da ressocialização.

Ainda que o art. 59 do CPB diga que se deve aplicar a pena necessária para a repressão e prevenção do delito, a interpretação desse dispositivo não pode abrir mão da realidade. 
Nenhuma regra hermenêutica permite que o juiz leve em consideração fatos desmentidos pela vida $^{116}$.

Por isso que o objetivo de prevenção do delito não pode abranger uma futura e inviável ressocialização no cárcere. Neste ponto sempre atual a lição de Miguel Reale Júnior que, após fazer as devidas considerações sobre "as nefastas consequências do encarceramento" (1983, p. 27), assim se pronuncia:

A pena, de conseguinte, há de ser a estritamente necessária e suficiente para que se constitua em justa retribuição. Doutra parte, pensando em evitar que a pena se torne maléfica e prejudicial ao acusado, é mister que seja aplicada, também com vistas á prevenção. Cumpre, destarte, escolher a modalidade de pena que necessariamente deva ser adotada a fim de propiciar a preservação e valorização da pessoa do condenado (Idem, p. 48).

Se a prisão causa malefícios, não só ao condenado, mas também à sociedade que o terá de volta pior depois de alguns anos, a finalidade de prevenção da pena prevista no art. 59 do CPB deve ser interpretada em cotejo com a necessidade de se preservar o ser humano que é o sentenciado.

O Estado não pode esquecer que o réu é sujeito de direitos e que a pena deve ser resultado de um procedimento legal constituído de clareza e racionalidade. O princípio da legalidade não pode ser relativizado em nome de argumentos que longe de serem científicos parecem mais encobrir sentimentos vingativos.

Quando isso acontece o réu não é mais parte em um procedimento legal, com direitos e deveres estritamente previstos, mas é um objeto ao qual não se atribui qualquer consideração. E visto por esse ângulo, não só o princípio da legalidade é violado, atinge-se igualmente a própria dignidade da pessoa humana (SARLET, 2002), base e fundamento do Estado Democrático de Direito.

E, advirta-se, não vai aqui nenhuma crítica vazia, o procedimento adotado na decisão examinada, infelizmente, não é um caso isolado. O termo ressocialização vem sendo usado no

\footnotetext{
${ }^{116}$ Pertinentes as considerações do Professor Eros Grau: “Ademais, após observar que o direito é produzido a partir de múltiplas inter-relações, compreendi a necessidade de o pensarmos dialeticamente, estudando-o em movimento, em constante modificação, formação e destruição - isto é, como de fato ocorre na realidade concreta" (2008, p. 44).
} 
mesmo sentido em diversas outras oportunidades pelo judiciário, como um argumento forte para justificar a aplicação de um regime mais rigoroso ${ }^{117}$.

Algumas decisões chegam a se aproximar da religiosidade:

[...] somente o regime inicial fechado revela-se adequado à perfeita individualização da pena e no próprio aproveitamento da terapêutica penal pelo condenado, voltada à ressocialização a fim de que possa após refletir sobre sua conduta buscar o alto e a retidão (TJ-SP. $3^{\text {a }}$ Cam. Crim.- São Vicente - Rel. Gustavo Alexandre Belluzo - J. em 17/12/09).

Em outros casos o regime é agravado corretamente, proporcionalmente à pena base estipulada, todavia esta é agravada com a afirmação de que assim o foi para a ressocialização do acusado: TJMG, $3^{\mathrm{a}}$ Câm. Crim., Des. Rel. Antônio Carlos Crunivel, Ap. 1.0024.08.0744188/001(1), Julg. Em 02/06/09, Publ. em 31/07/09; Ap. 1.0082.07.005537-9/002(1), Julg. Em 09/03/10, Publ. em 16/04/10; TJMG, 4 a Câm. Crim., Des. Rel. Fernando Starling: Ap. 1.0153.02.016404-9/001(1); Julg. Em 10/02/10; Publ. em 01/03/10.

As relações de jurisprudências trazidas são exemplificativas. Não obstante, justamente por não se pretender apresentar um rol exaustivo, e verificando-se a facilidade de se encontrar decisões no mesmo sentido, percebe-se um indício forte de que o argumento ressocializador é usado sem subterfúgios.

\subsubsection{A fixação do regime de cumprimento de pena e o STF}

O Supremo Tribunal Federal tem mantido posição em defesa do princípio da legalidade, no momento do estabelecimento do regime de cumprimento da pena privativa de liberdade. Contudo, trata-se de posição jurisprudencial que nem sempre foi unânime e mesmo hoje não é mantida sem maiores divergências.

\footnotetext{
${ }^{117}$ No mesmo sentido: TJ-RJ, $2^{\text {a }}$ Cam. Crim., Ap. 0273566-49.2007.8.19.0001, Des. Rel. Kátia Jangutta, J. em

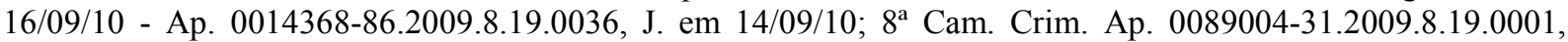
Des. Rel. Marcus Quaresma Ferras, J. em 15/09/10; $1^{\text {a }}$ Câm. Crim., Ap. 0205262-27.2009.8.19.0001, Des. Rel. Antonio Jayme Boente, j. em 01/09/2010 - TJRS, Ap. n 70026961052, 2 $2^{\text {a }}$ Câm. Crim., Des. Rel. José Antônio Cidade Pitrez, Julgado em 27/11/2008 - TJMG, $4^{\text {a }}$ Câm. Crim., Ap. n. 029007047789-5, Des. Rel. Delmival de Almeida Campos, j. em 05/11/2008, pub. em 19/11/2008 - TJSP, 6a Câm. Crim., Ap. 990.10.206686-0, Des. Rel. Ricardo Tucunduva, j. em 16/09/2010; $3^{\text {a }}$ Câm. Crim., Ap. 990.09.130851-0, Des. Rel. Ruy Alberto Leme Carvalho, j. em 10/08/2010; $1^{\text {a }}$ Câm. Crim, Ap. 990.08.192797-7, Des; Rel. Jayme Garcia dos Santos Júnior, j. em 06/08/210 - TJDFT, 2a T. Crim., Ap. 20080310328894, Rel. Sérgio Rocha, j. em 15/10/2009, Dj 13/01/2010).
} 
Por se tratar de decisão onde é possível encontrar um amplo debate sobre a fixação do regime de prisão em contraste com a pena base adotada na sentença, opta-se por examinar o Habeas Corpus no 86.785-5/SP, em que foi relator o Ministro Marco Aurélio, e está ementado da seguinte forma:

PENA - CUMPRIMENTO - REGIME - PARÂMETROS. Excetuada a fixação da pena em quantitativo superior a oito anos e não se tratando de reincidente, a determinação do regime de cumprimento da pena é norteada, considerando o balizamento temporal, pelas circunstâncias judiciais. Inteligência dos $\S \S 2^{\circ}$ e $3^{\circ}$ do artigo 33 do Código Penal. Mostra-se incongruente o estabelecimento da pena-base no mínimo previsto para o tipo, ficando aquém dos oito anos, com imposição do regime fechado (Julgamento em 23/05/2006, publicação D.J. em 29/09/2006, decisão tomada por maioria de votos, vencidos os Ministros Carlos Brito e Ricardo Lewandowski) ${ }^{118}$.

Ocorre que a posição tomada pela Corte Constitucional não livra o ordenamento jurídico nacional de considerações como as que até agora foram abordadas. A legalidade preservada pelo STF, no caso, é apenas uma legalidade formal.

A súmula 719 do STF, já referida, dispõe que o juiz só pode determinar um regime mais grave do que aquele cabível com fundamento na pena base se assim fizer de forma motivada. Ao mesmo tempo, a decisão acima colacionada é no entendimento de que é incoerente o estabelecimento da pena base no mínimo em conjunto com um regime mais grave do que o cabível na espécie.

Ambos os posicionamentos se completam. $O$ primeiro, o da súmula, exige fundamentação todas as vezes que se vá aplicar um regime de pena mais grave do que aquele estabelecido na lei. Procedimento, como dito, limitador da discricionariedade do magistrado na aplicação da pena, mas também garantidor de princípios constitucionais básicos, como o da legalidade e o da ampla defesa.

O segundo, de forma objetiva, diz que se a pena base for fixada no mínimo, o juiz não poderá estabelecer regime mais grave. Ora, trata-se de manter o mínimo de coerência na fixação da pena, pois se as circunstâncias são as mesmas (as do art. 59 do Código Penal), tanto para a imposição da pena base quanto para a adoção do regime de cumprimento da pena, não haveria como considerar-se as circunstâncias favoráveis em um momento e desfavoráveis em outro.

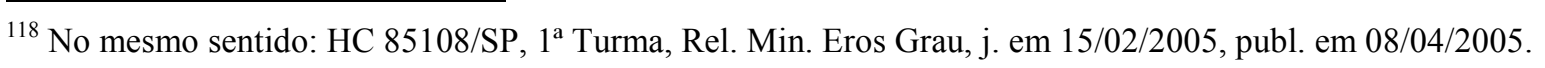


No segundo caso, a seguir-se a interpretação do STF, nenhuma motivação seria possível para o estabelecimento do regime prisional mais gravoso em casos de pena base fixadas no mínimo. Entretanto, além do fato de que poucos arestos em sentido contrário acabam sendo submetidos à apreciação do STF, muitos tribunais não seguem a orientação da corte superior:

É importante enfatizar que têm sido comuns discrepâncias inaceitáveis em sentenças condenatórias, pois, muitas vezes, analisando-se os mesmos critérios apontados pelo artigo 59 do Código Penal, o magistrado fixa a pena base no mínimo legal e, apesar de o condenado preencher os requisitos objetivos para iniciar o cumprimento de sua pena em regime menos grave, o magistrado determina o regime mais grave (PASCHOAL, 2003, p. 118) ${ }^{119}$.

Outrossim, uma questão é de suma importância e merece ser tratada aqui. A diretriz do STF não impede que os tribunais continuem utilizando o argumento da ressocialização como fundamentação para a imposição de regime prisional mais grave.

O controle que se pode atribuir à diretriz do STF é somente formal, pois basta que o tribunal encontre um argumento qualquer para somá-lo à necessidade de ressocialização que estará fundamentando o regime prisional.

Aliás, nesta mesma decisão do HC 86.785-5/SP, pode-se perceber tal tendência no voto do Ministro Carlos Brito, mais precisamente na sua confirmação de voto:

Senhor presidente, também me deixei impressionar pela inserção do Ministro Ricardo Lewandowski quando colocou em ênfase que a pena base e regime prisional tem finalidades distintas. E, na fixação do regime prisional, o juiz há de levar em conta a segurança da sociedade, a possibilidade de ressocialização, ou não, do agente (Fls. 1638 da decisão)

Portanto, mesmo na mais alta corte do país a ideia de ressocialização está viva como possibilidade de se agravar a sanção de uma pessoa, em total descompasso com a realidade, notadamente com a realidade carcerária.

Como se pode observar nos votos colhidos por ocasião da votação no HC em questão, o STF entende que somente circunstâncias concretas podem ser levadas em consideração para o agravamento da pena ou para a fixação do regime, sendo inviável a consideração da conduta típica em abstrato para esse efeito, posicionamento que vem a favor do princípio da legalidade.

\footnotetext{
${ }^{119}$ Em nota de rodapé a autora constata que "esse tipo de disparidade é muito encontrada nas condenações pelo crime de roubo com uso de arma" (PASCHOAL, 2003, p. 118).
} 
De fato, já estando a gravidade do crime considerada pelo próprio legislador ao criar os limites mínimos e máximos das penas, não pode o juiz sentenciante renovar a consideração da gravidade do fato em abstrato para aplicar uma pena acima do mínimo. Em outras palavras, a pena mínima já abrange a gravidade do crime em abstrato, portanto não há como o juiz fazer uso dessa gravidade como causa para elevar a sanção acima do mínimo, sob pena de incorrer em evidente bis in idem.

Tal conduta, de se considerar a gravidade do crime em abstrato, que ocorre equivocadamente (ou maliciosamente) em diversas situações, seja no aumento da pena, seja no da escolha do regime, e até mesmo, ou principalmente, na recusa de aplicação de muitos direitos inerentes à execução da pena, é uma desculpa infundada a ser criticada e, como bem coloca a Mariângela de Magalhães Gomes (2003, p. 178), beira às raias da "aberração".

Certo, não se discute aqui se o juiz possui boa dose de discricionariedade para estabelecer o regime de cumprimento da pena. Afinal, a letra do art. 33 do Código Penal deixa claro isso. Assim, havendo circunstâncias relevantes dentro do extenso rol do art. 59 do Código Penal, poderá o juiz, fundamentadamente, estabelecer regime mais grave dentro das hipóteses do referido art. 33. Contudo, a questão que se quer enfatizar é o absurdo de trazer a consideração, na sentença, de que tal medida é tomada em prol da ressocialização do condenado.

O Direito poderia ser menos dissimulado, a fim de possibilitar o mínimo de diálogo entre a atividade estatal e a comunidade. Insta reconhecer nas decisões o caráter puro e simples da retribuição, porque a pena privativa de liberdade nunca teve nem nunca terá a possibilidade de preparar para a vida em sociedade aquele que ela recolhe e afasta do convívio social. Se a retribuição é o melhor caminho político a ser adotado é coisa a se discutir em outras ocasiões. No momento, o que se pede é uma postura jurídica mais próxima da realidade e uma pena aplicada dentro de critérios claros, ainda que retributiva.

Voltemos ao posicionamento do STF. O que se colheu do voto do Ministro Carlos Brito nada mais é do que vestígio de uma não tão antiga posição daquele tribunal:

HABEAS-CORPUS. CRIME DE ROUBO QUALIFICADO. REGIME PRISIONAL INICIAL. 1. A periculosidade do agente, revelada pela prática do crime de roubo qualificado pelo uso de arma e concurso de pessoas, pode constituir motivação 
bastante para fixação do regime inicial fechado. 2. A pena-base e o regime prisional têm finalidades distintas, ainda que fixados com a utilização dos mesmos critérios: na aplicação da pena vela-se unicamente pela dosagem da reprimenda, enquanto que na fixação do regime objetiva-se tanto a reeducação do agente como a segurança da sociedade. 3. A lei desatrela a pena aplicada do regime prisional, ainda que fundados nos mesmos critérios, ao impor o regime fechado ao condenado à pena privativa de liberdade superior a 8 anos e ao facultar o regime semi-aberto ao condenado à pena de mais de 4 até 8 anos $\left(\mathrm{CP}\right.$, art. $33, \S 2^{\circ}$, a e $\left.\underline{b}\right)$, de forma a permitir que o Juiz, levando em conta a periculosidade do agente e segurança da sociedade, imponha o regime prisional adequado (...) $)^{120}$ (STF, $2^{\mathrm{a}}$ Turma, HC 75.6638/SP, Min. Rel. Maurício Corrêa, j. em 30/09/1997, publ. em 27.04.2001) (Primeiro grifo meu, os demais no original).

Interessante notar como o pensamento desse acórdão está impregnado na prática jurídica nacional. Não só nas decisões até agora tratadas dos tribunais de justiça, mas no próprio $\mathrm{STF}$, como se observou no rápido debate sobre a finalidade da pena na decisão do $\mathrm{HC}$ $86.785-5 / \mathrm{SP}$.

Conceitos como periculosidade, reeducação e segurança da sociedade são extremamente maleáveis, ferindo de morte uma pena baseada no princípio da legalidade. Nem o condenado, nem a sociedade sabem o que passa pela mente do julgador quando este utiliza tais argumentos.

Assim, à pessoa do acusado pode ser aplicada qualquer pena, em qualquer intensidade, porque uma reeducação fictícia no cárcere pode ser qualquer coisa na mente de qualquer um. O que se vê, na verdade, é um total desrespeito que faz do réu um sujeito (objeto) sem proteção no momento da individualização da pena, atingidos direitos seus "que são parte integral e substancial de sua personalidade" (SHECAIRA, 1999, p. 159).

Fica evidente a mudança de orientação do STF, pois se atualmente, fixada a pena base no mínimo legal não se pode estabelecer um regime mais grave do que o previsto no art. 33 do $\mathrm{CP}$, obviamente que não há que se falar em objetivos reeducadores, ressocializadores, ou em qualquer outro instrumento re na hora de se estabelecer o regime prisional. Ou seja, tanto para a fixação da pena com base no art. 59 do CP, quanto para o estabelecimento do regime

\footnotetext{
${ }^{120}$ Decisão no mesmo sentido no STJ, de que "a relevância da definição do regime prisional decorre do sentido e da função da pena, que não deve ser concebida como instrumento de castigo, mas em consonância com os modernos desígnios que realçam a recuperação moral e social do réu" (REsp 60251/SP, Rel. Ministro VICENTE LEAL, $6^{\text {a }}$ Turma, j. em 27/02/1996, DJ 27/05/1996).
} 
prisional, o que deve contar são circunstâncias concretamente verificadas pelo juiz com base no critério apresentado no art. 59.

Ocorre que tal posicionamento, além de não ser firme nem no STF, ainda deixa um grande espaço para a permanência da prática nefasta de se impor um regime de cumprimento de pena dissociado da própria argumentação no momento da fixação da sanção. O que sói ocorrer nos casos em que as penas não são fixadas no mínimo legal, mas permitem, pela intensidade, o início do cumprimento em regimes prisionais menos rigorosos que o fechado.

É o caso de muitas das decisões trazidas neste trabalho. Casos em que o magistrado aplica a pena acima do mínimo, mas, dentro do critério do art. 33 do $\mathrm{CP}$, o regime para aquela pena poderia ser o aberto ou o semiaberto. Então, o juiz faz uso do argumento ressocializador e aplica o regime fechado.

\subsubsection{A substituição por pena restritiva de direitos}

Assim como fez com a pena base e com a fixação do regime inicial de cumprimento da pena, o legislador também usou o parâmetro das condições judiciais para que o juiz decidisse sobre a possibilidade ou não de substituição da pena privativa de liberdade por pena restritiva de direitos, conforme disciplinado no art. 44 do Código Penal.

É o que Helena Lobo da Costa chama de "multifuncionalidade" (2008, p. 70) do art. 59 do Código Penal. A diferença é que ao invés de o art. 44 se reportar ao art. 59 para estabelecer as condições judiciais, repete a maioria delas como condições também para o juiz decidir sobre a substituição ou não da pena de prisão por pena restritiva de direitos.

Mantém-se no art. 44 do Código Penal, inciso III, como condições para a substituição, $\mathrm{o}$ atendimento à culpabilidade, à conduta social, à personalidade do agente, aos motivos e às circunstâncias do crime, deixando-se de repetir: condições do crime e comportamento da vítima; condições presentes somente no art. 59.

Então, a prevalecer o raciocínio do STF, fixada a pena base no mínimo legal, vez que ausente qualquer circunstância judicial desfavorável contra o acusado, e estando a pena dentro 
dos parâmetros do art. 44 do Código Penal ${ }^{121}$, seria necessário que o juiz substituísse a pena de prisão por pena restritiva de direitos. Todavia, não é bem o que tem acontecido.

Assim como, independentemente do quantum da pena, tem-se visto a fixação de um regime prisional mais grave com base no argumento ressocializador, decisões têm afastado a aplicação da chamada pena alternativa $^{122}$ também com fundamento na falácia da ressocialização.

DIREITO PENAL. ART. 334, $\S 1^{\circ}$, C, DO CP. EMENDATIO LIBELLI. MATERIALIDADE. AUTORIA. ERRO DE TIPO. DOSIMETRIA DA PENA. CIRCUNSTÂNCIAS JUDICIAIS DO ART. 59 DO CP. PROPORCIONALIDADE. ATENUANTE DA CONFISSÃO. INCIDÊNCIA. REGIME PRISIONAL MAIS SEVERO. SUBSTITUIÇÃO POR RESTRITIVAS DE DIREITOS. 1. O réu foi preso em flagrante ao manter em depósito objetos de procedência estrangeira, verificando-se a materialidade e autoria do delito descrito na alínea 'c' do art. 334 do Código Penal. Cabível a emendatio libelli, com apoio no art. 383 do CP, visto que o agente se defende dos fatos e não da capitulação legal contida na denúncia. 2. Descabe acolher a tese da defesa de que o acusado desconhecia serem as mercadorias produto de descaminho, se além de desacompanhadas da documentação legal, eram utilizados 'laranjas' para seu transporte. 3. A existência de tão-só uma circunstância judicial desfavorável justifica pequeno acréscimo na pena-base. 4. Sendo a regra de caráter objetivo, havendo admissão da responsabilidade pelos ilícitos, aplica-se a atenuante prevista no art. 65, III, "d", do CP. 5. Dadas as peculiaridades do caso concreto e o exame das vetoriais do artigo 59 do $\mathrm{CP}$, tanto a alteração do regime inicial semi-aberto, quanto a permuta por medidas alternativas não se mostram aconselháveis, nem suficientes para a repressão do crime e ressocialização do condenado. (TRF, 4a Reg, $8^{\text {a }}$ Turma, Ap. Crim. 200770050032224, Rel. José Paulo Baltazar Júnior, Julg. em 02/04/2008) (Grifei).

Veja-se que a decisão ora citada faz referência a uma pena aplicada próximo ao mínimo, inclusive com a presença de atenuante, sendo delito sem violência à pessoa, portanto presentes todas as condições do art. 44 do Código Penal, mas onde foi negada ao réu a substituição da pena privativa de liberdade por restritiva de direitos, sob o argumento de que era medida insuficiente para a repressão e ressocialização do condenado.

Não há que se discutir a opção de política criminal do julgador, que entende a pena mais grave como necessária para a repressão do crime, até porque não é objeto deste trabalho. Registre-se, tão-somente, que o caráter expiatório e punitivo da pena pode mesmo ser

\footnotetext{
${ }^{121}$ As demais condições estão no inciso I e II do art. 44 do Código Penal: "aplicada pena privativa de liberdade não superior a quatro anos e o crime não for cometido com violência ou grave ameaça à pessoa ou, qualquer que seja a pena aplicada, se o crime for culposo"; e "o réu não for reincidente em crime doloso".

${ }^{122}$ Vulgarmente denominadas penas alternativas, as sanções do art. 43 são, a bem da verdade, penas substitutivas, estas que não se confundem com a pena alternativa que "é espécie de pena originária que pode ser aplicada desde $\mathrm{o}$ início e de forma direta. Na pena substitutiva, deve o julgador aplicar necessariamente a pena originária correspondente, no caso, a pena privativa de liberdade, para, em seguida, substituí-la" (PRADO, 2002, p. 480.)
} 
considerado contraditório com o próprio fim ressocializador (SÁ, 2010) anunciado na decisão em comento.

Política criminal, dogmática e prática judicial devem estar interligadas, favorecendo seja dado ao direito penal um caráter de ciência social (CAMARGO, 2002-a), mas para que essa união seja efetiva, as circunstâncias públicas e notórias da realidade devem estar incluídas nessa construção. Deseja-se aqui enfatizar, que mais uma vez, em mais uma ocasião da individualização judicial da pena, fere-se de morte o princípio da legalidade em nome de algo fictício.

O mais grave é que no caso em questão se alguma forma unilateral, promovida institucionalmente, de ressocialização fosse possível, esta só poderia ocorrer por meio da pena restritiva de direitos, sanção que comprovadamente tem um índice de reincidência menor ${ }^{123}$. Mas o julgador preferiu, em nome da ressocialização, aplicar a pena mais destruidora e segregadora, em descarada incoerência.

E mais uma vez a prática do uso do argumento ressocializador como forma de se aplicar a pena mais grave, no caso a pena de prisão quando se permitiria, em tese, impor uma pena restritiva de direitos, não é um caso isolado, e há igualmente inúmeros julgados nesse sentido $^{124}$.

\footnotetext{
${ }^{123}$ Pesquisa realizada pela UNB (Grupo Candango de Criminologia) entre os anos de 1997 e 1999 informa que no Brasil o índice de reincidência das penas restritivas de direito é $24,2 \%$, menos do que o dobro do registrado entre os condenados a penas privativas de liberdade que foi de $53 \%$. Disponível em $<$ http://www.unb.br/noticias/bcopauta/index2.php?i=603>. Acesso em: 25/11/10. Resultado equivalente traz o estudo realizado pelo Ilanud em parceria com o IBCCrim, de onde se colhe que a reincidência nas penas de prisão, no Brasil, está entre $48 \%$ e $85 \%$, enquanto a pena de prestação de serviços a comunidade, no Rio Grande do Sul, no ano de 1993, teve o índice de reincidência de 12,54\%. Em Cleveland, nos Estados Unidos, a prisão teria índice de $64 \%$, enquanto os prestadores de serviço $37 \%$. Disponível em <www.ibccrim.org.br/upload/nucleos/implementacao de programas 1998.pdf $>$. Acesso em: 25/11/10.

${ }^{124}$ Em relação exemplificativa de jurisprudência: TJ-RJ, $1^{\text {a }}$ Cam. Crìm, Ap. Crim. 0232706-35.2009.8.19.0001, Des. Rel. Antônio Jayme Boente, j. em 05/05/10; $7^{\text {a }}$ Cam. Crim, Ap. Crim.0002711-12.2007.8.19.0039 (2009.050.02235), Des. Rel. Márcia Perrini Bodard, j. em 03/09/2009; $8^{\text {a }}$ Câm. Crim., Ap. Crim. 01368199.2006.8.19.0001 (2009.050.04413), Des. Rel. Valmir Ribeiro, j. em 02/09/2009; 6 Câm. Crim., Ap. Crim. 0001188-70.2004.8.19.0038 (2008.050.01349), Des. Rel. Rosita Maria de Oliveira Netto, j. em 04/08/09 - TJMG, $5^{\text {a }}$ Câm. Crim., Ap. 1.0439.02.012592-8/001(1), Des. Rel. Maria Celeste Porto, j. em 09/10/07 - TJ- DFT, $1^{\text {a }}$ Turma Crim., Ap. 2008091 010154-8 APR - 0010154-06.2008.807.0009 (Res.65 - CNJ), Rel. Mário Machado, j. em 05/11/09; $2^{\text {a }}$ Turma Crim., Ap. APR - 0032889-51.2008.807.0003 (Res.65 - CNJ), Rel. Sérgio Rocha, j. em 15/10/2009 - TJ-RS, 2a Câm. Crim, Ap. 70026088526, Des. Rel. Laís Rogéria Alves Barbosa, j. em 12/03/09 TJ-ES, $2^{\text {a }}$ Câm. Crim., Ap. 006070005449, Rel. Sérgio Luiz Teixeira Gama, j. em 08/06/09.
} 
Cumpre explicar, se ainda não ficou claro o suficiente, que muitas dessas decisões podem realmente tratar de casos em que a substituição da pena privativa de liberdade por pena restritiva de direitos podia não ser a medida legalmente aplicável. O que se quer combater é o argumento. Deixa de ser legal, justa ou compreensível a decisão que veda tal substituição com o argumento de que assim o fez em nome da ressocialização.

Se o réu preenche os requisitos objetivos do art. 44 do Código Penal, somente uma das circunstâncias subjetivas do inciso III, desde que expressamente identificada pelo juiz, e de forma claramente fundamentada, pode afastar a substituição da pena privativa de liberdade por uma alternativa penal.

Tal postura seria a mais condizente com um Estado Democrático de Direito, onde a pena contra um de seus cidadãos só pode ser aplicada dentro da mais estrita legalidade, permitindo-se a compreensão do raciocínio do órgão julgador por parte não só do acusado, mas de toda a comunidade.

\subsubsection{A dignidade humana como parâmetro}

Se se pretende manter o caráter dialogal do Direito, como instrumento de estabilidade e de harmonia nas relações sociais, regulador do convívio social, assegurador de condições mínimas de existência e paz a todos, solucionando e não mascarando conflitos, "impondo, por assim dizer, uma ratio à própria realidade humana" (PRADO, 2002, p. 35), necessário construir um Direito acima de tudo sincero.

O medo, o terror e a violência das ruas, assim como os preconceitos, os ódios e as decepções do julgador, não podem integrar as razões de decidir. São sentimentos naturais de qualquer ser humano e precisam estar conscientes - por isso devem sempre ser denunciados para que a reflexão do magistrado permita afastá-los na ocasião de decidir.

Uma decisão que leva em consideração o medo do próprio juiz, expressado ou não, consciente ou não, como razão de decidir, apenas prejudicará a própria validade do Direito como instrumento de pacificação. Neste caso, o que teríamos seria simplesmente força física contra força física, o uso do direito como instrumento de guerra. 
Não se pede, e seria impossível, que o juiz seja uma máquina sem sentimentos. O que se pretende é justamente que o juiz se perceba como ser humano e faça dos seus sentimentos instrumento de justiça, um elo com a realidade, o caso concreto posto sob julgamento e a lei.

Pior que a lei desvinculada da realidade é a decisão judicial, pois esta possui o pressuposto de que o juiz está mais perto que o legislador das relações sociais valoradas. Assim, uma decisão judicial fundamentada em argumento falho, sem crédito na sociedade, só faz aumentar a ilegitimidade do sistema. Leonardo da Vinci já dizia que "aquele que espera da experiência algo que não está nela, distancia-se da razão" (1997, p. 45).

Pode-se argumentar que a ressocialização é um termo também usado em benefício do acusado, seja na aplicação da pena ou na execução desta. Sim, muitos juízes utilizam o termo ressocialização no sentido de que a pena de prisão deva ser atenuada ou excluída para fins de ressocialização.

Mas tal constatação está longe de fazer do termo combatido algo razoável na prática do direito, muito pelo contrário, o seu uso em diversos contextos e para diversas finalidades só demonstra o quão arbitrário pode ser, distante de qualquer concepção de um direito penal baseado em uma estrita legalidade.

Certo que a lei, o Código Penal em seu art. 59, dispõe deva a pena ser aplicada para prevenção e repressão do delito, mas em nenhum momento a legislação faz referência à ressocialização como fim da sanção penal ${ }^{125}$, e mesmo que fizesse a interpretação da regra não poderia abstrair a realidade.

O malogro do regime prisional, com as taxas altíssimas de reincidência adicionadas ao fator criminológico do cárcere, não foi ainda devidamente sentido pela dogmática penal brasileira. (...) A dogmática precisa perceber, de modo a redimensionar os seus conceitos, a fraqueza científica dos argumentos que legitimam o cárcere. Essa irradiação, na via de retorno, poderá permitir que a abertura cognitiva confira ao intérprete novo ferramental dogmático. Este novel conjunto de conceitos pode assumir as informações sobre a pena, transformando-as em determinantes para a sua aplicação concreta (SALVADOR, 2009, pp. 97-98).

Dentro dessa perspectiva de se interpretar a lei levando em consideração as informações sobre a pena que, mesmo em legislações aonde o fim reeducativo da sanção vem

${ }^{125}$ Relembre-se que a Lei de Execução Penal dispõe tenha a execução como fim a "harmônica integração social do condenado" (art. $1^{\circ}$ ), o que, porém, não indica que a ressocialização pode ser usada como instrumento unilateral do Estado contra o sentenciado. 
expressamente estipulado, há a tendência de se interpretar ressocialização com base no seu conteúdo e não com base em seu ideal.

Tendo, como dito, o ideal de ressocialização nascido como forma de se humanizar a pena de prisão, o correto é interpretar ressocialização como uma pena que deve ter caráter humano, respeitando a pessoa do condenado como sujeito de direitos, afastando a sua percepção como objeto.

Se a origem e o conteúdo da ressocialização é a pena humanizada, pretendida pelos precursores da nova defesa social, o certo é que "o conceito de ressocialização seja reinterpretado no marco mais amplo dos princípios constitucionais inspiradores do Estado Social de Direito e, em particular, do princípio dinâmico de igualdade e do princípio da dignidade do homem" ${ }^{\prime 26}$ (BARATTA, 2006, p. 20).

A preocupação do professor italiano é mais de política criminal, razão pela qual ele prega seja a "utopia da ressocialização"127 (Idem, Ibidem), ssubstituída por projetos alternativos aos de direito penal, ao que ele chama de reintegração social, atuando sobre as origens do conflito e agindo sobre o autor do fato, a vítima e o ambiente. Sobre o assunto voltaremos a falar no último capítulo.

A nosso ver, nem mesmo o termo reintegração social, muitas vezes usado na prática cotidiana como sinônimo de ressocialização, pode ser utilizado na dogmática ou na jurisprudência com intuito de fundamentar o agravamento de pena ou a negação de direitos expressamente previstos ao réu ou ao condenado.

Independentemente, contudo, da palavra a ser usada para se referir a uma sanção penal menos desumana, a própria sinceridade do direito já seria um grande passo para uma maior integração do sujeito do processo penal, conforme os objetivos de Baratta.

\footnotetext{
${ }^{126}$ Na obra consultada: "El concepto de 'reinserción social' sea reinterpretado em el marco más amplio de los principios constitucionales que inspiran el estado social de derecho y, em particular, del principio dinâmico de igualdad y del principio de la dignidad del hombre" (BARATTA, 2006, p. 20).

127 "utopía de la reinserción" (Idem, Ibidem).
} 
Com a reinterpretação do conceito e levando-se em consideração a realidade prisional, a impossibilidade fática da ressocialização entre grades e muros, o termo ressocialização deve ser entendido como necessário respeito à dignidade humana na pena.

Desta forma, abre-se espaço para que a finalidade preventiva da pena, prevista na lei, seja entendida conforme a realidade, ou seja, sempre na direção de se considerar a pena de prisão ultima ratio.

Nada impede, porém, que razões de prevenção especial levem o juiz a fixar uma pena abaixo do limite determinado pela retribuição justa da culpabilidade, evitando-se o efeito dessocializador que a pena privativa de liberdade possa exercer, substituindo-a então por medidas alternativas (COSTA JR, 2008, p. 59)

Poder-se-ia arguir, mais uma vez, que a retirada do termo ressocialização da interpretação e aplicação da lei penal ou penitenciária poderia prejudicar o réu ou o condenado, porque o termo também é usado em benefício do mesmo. Mas não é o caso, pois em todas as circunstâncias em que o termo ressocialização aparece como fundamento para um tratamento menos severo no direito penal, este poderia facilmente ser substituído por dignidade da pessoa humana. Trata-se, isto sim, de retirar um grande ruído da interpretação da lei penal.

Aliás, esta deveria ser a diretriz a ser usada não só pelo interprete, mas também pelo legislador. Na advertência de Salomão Shecaira, "a positivação do direito penal deve ter como parâmetro fundamental, pois, a condição humana e como referência externa o conceito de Estado Democrático de Direito" (1999, p. 159).

E para que Estado Democrático de Direito não acabe sendo considerado como somente mais uma nomenclatura é necessário que os seus participantes sejam levados a sério (GRECO, 2009) e respeitados, não havendo espaço para tratamento diferenciado em nenhuma esfera de atuação. $\mathrm{O}$ respeito que todos merecem em face do Estado passa pela observância integral do princípio da legalidade, e este permitirá que toda a comunidade tenha conhecimento da norma, compreenda a atividade estatal e possa se comportar de forma compatível com esse conhecimento.

Nesse contexto, nenhuma atividade obscura ou com fundamentos desconhecidos pela sociedade é compatível com a dignidade de seus integrantes. Deve-se repetir: o uso do termo 
ressocialização, incompreensível, impossível, quase ridículo quando se imagina as celas imundas em que são colocados os que deveriam ser cidadãos sujeitos de direito, acaba se tornando um grande obstáculo para a clareza inerente e fundamental aos princípios da legalidade e da dignidade humana.

\subsection{REMIÇÃO PELO TRABALHO NA EXECUÇÃO PENAL}

Foi escolhido como primeiro tema específico sobre execução penal a ser abordado o trabalho realizado no interior do cárcere, e assim o foi por um simples motivo: porque é justamente com o trabalho que tanto a legislação, como todo o movimento de defesa social, e boa parcela da sociedade, pensam na capacidade ressocializadora da pena privativa de liberdade.

A interpretação da atividade laboral do preso também deveria ser submetida ao princípio da legalidade, mas veremos que a ressocialização como ideal acaba dificultando essa avaliação estritamente objetiva.

\subsubsection{A natureza do trabalho}

O trabalho penitenciário é instrumento da ressocialização. Com o trabalho o preso deveria assimilar os valores tão caros de nossa sociedade e aprender a não delinquir, não se demonstrar um desviado, um desajustado. É com o trabalho que foi imaginado o milagre da transformação desse ser humano, primeiramente doente e depois inimigo da sociedade, conforme a escola que ia estudando e formando a diretriz do direito penal.

Desde Howard, no século XVIII, era com o trabalho que os males do cárcere iriam ser amenizados. Trabalho em silencio, trabalho solitário na cela, trabalho em conjunto, trabalhos forçados, sempre trabalho. Antes mesmo era o trabalho nas galés, depois o trabalho limpo, saudável, higiene espiritual, profilaxia contra a má conduta. Se o sistema penitenciário ruiu e a prisão tornou-se "a detestável solução, de que não se pode abrir mão" (FOUCAULT, 1998, p. 196), foi acompanhada do trabalho que isso aconteceu. 
Mas, ao lado dessa ressocialização pelo trabalho, desde que as riquezas passaram a não ser mais medidas por terras ou títulos de nobreza, na sociedade livre sempre houve uma socialização igualmente pelo trabalho. O valor de cada um, o nível de sua participação social sempre foi proporcional ao valor e nível do trabalho que exerce. Não se adquire dignidade sem uma atividade laboral reconhecidamente digna. Anabela Rodrigues (2000) bem lembra que, apesar de todo o avanço constitucional na esfera das liberdades, nunca uma constituição positivou a liberdade de não trabalhar.

A importância dada ao trabalho foi resultado de uma evolução histórica, porque houve tempo em que trabalhar era indigno ${ }^{128}$. No entanto, essa valorização do trabalho, que cresceu juntamente com o fortalecimento de direitos civis e políticos, e com a consequente maior liberdade do cidadão, tinha também a função de controle:

Quer dizer, ao trabalho está vinculada uma fixação cotidiana de sentido e controle, uma estrutura de domínio interiorizada. As pessoas se ocupam e, com isso, tornam-se controláveis. Pode-se dizer que o desejo de construir uma atividade via mercado de trabalho e, com ela, uma existência, uma biografia, uma identidade, é uma das formas mais hábeis de auto-adaptação e auto-ajustamento dos indivíduos à estrutura de domínio social (BECK, 2003, p. 164).

Os que não se integravam nesse autocontrole eram disciplinados rigidamente em instituições como a escola, o quartel e a fábrica. Cresceu a importância do horário, do ritual e da mecânica do comportamento no que Foucault definiu como sociedade disciplinar ou panóptica (1998). O projeto arquitetônico de Bentham de vigilância e disciplina não era destinado só para penitenciárias, mas para todas as instituições de controle.

Em verdade, Foucault descobre o Panóptico pesquisando projetos de hospitais e, depois, estudando as prisões, ocasião em que percebe que é constante a referência ao projeto de Jeremy Bentham (FOUCAULT, 2009). A preocupação com a vigilância e o controle existente em vários projetos de instituições que usaram o Panóptico como modelo fez com que o filósofo o usasse como metáfora para descrever a sociedade moderna.

\footnotetext{
${ }^{128}$ Ulrick Beck resume bem essa perspectiva: "Na história das culturas e do desenvolvimento da civilização ocidental, o conceito de trabalho foi o que sofreu a mais radical revalorização, coisa que não se pode imaginar com dramaticidade suficiente. Se identificarmos a alvorada da civilização ocidental com a Antiguidade grega, o trabalho era o estigma que excluía as pessoas da sociedade. Os que trabalhavam não eram membros da sociedade, que, na época, se concebia como comunidade política. Mulheres e escravaos, que se encarregavam do trabalho, eram externos, a eles se negavam até mesmo as qualidades humanas essenciais que estavam ligadas sobretudo às relações políticas na pólis. (2000, p. 159-160) (Grifo no original)
} 
Zygmunt Bauman faz, no entanto, a advertência de que o simbolismo do Panóptico pode fazer com que não notemos os diversos instrumentos de controle atuais: "metáfora quase perfeita das facetas cruciais da modernização do poder e do controle, a imagem do Panóptico pode no entanto depender demais da imaginação sociológica, impedindo assim, em vez de facilitar, a percepção da natureza da mudança atual” (1999, p. 57).

E o trabalho passa a ser um desses instrumentos de controle e alienação. Diante do produto, o trabalhador só vê objetos e desconhece a sua participação na produção e valorização dessas mercadorias. O prazer em laborar, produzir e vislumbrar o produto criado, com o valor do trabalho embutido, isso não há mais, o que significa dizer que muito do que faz do trabalho uma condição de humanidade se perdeu. $\mathrm{O}$ sistema de produção tornou-se o próprio panóptico, fazendo do trabalho algo mecânico, motivado somente pela necessidade de sobrevivência.

Com o acúmulo de riqueza e o excesso de força de trabalho, muito se perdeu da natureza disciplinar do trabalho porque não há mais necessidade para tanto. Aquele que antes era disciplinado passa a buscar a disciplina a todo custo, pois esta significa a tão almejada inclusão no mercado de trabalho. O medo da exclusão passa a servir de controle efetivo, dispensando a disciplina forçada, antes presente nas instituições de ensino ou nas fábricas.

Se é que já foi possível, nenhum poder atualmente tem condições de controlar toda a população, o que faz com que o objeto de observação seja alterado. Nos exemplos de Bauman, personalidades devidamente escolhidas, do mundo policial, artístico, esportivo etc. são selecionadas como modelo; e empresas de marketing selecionam os prováveis consumidores; quanto ao restante, o sistema se torna indiferente. Ao contrário do Panóptico, os mais observados hoje seriam os que possuem mais liberdade, seja no mercado, seja na rede de computadores ou nos meios de comunicação, formando assim o que Bauman denominou de mecanismo "sinóptico", 29 (Op. Cit., p. 60).

Outrossim, o trabalho perde a função de formar a personalidade da pessoa, esta não mais será o que produz, não mais se identificará com a sua atividade de mudar o mundo por

${ }^{129} \mathrm{O}$ mesmo conceito de sinoptismo encontramos em Mathiesen,(2003). 
intermédio do trabalho, porque modelos de pessoas são formados para fazer da individuação algo generalizado e preestabelecido.

Hoje não há mais necessidade de limitar quem entra e quem sai ou de ensinar onde se pode ir e onde não se pode, porque hoje quem está livre tem uma senha, seja do banco, seja na escola, seja no mundo digital. O controle não precisa mais ser feito disciplinarmente. $\mathrm{Na}$ sociedade que Deleuze chama de sociedade de controle, o homem não precisa mais ser disciplinado, basta que seja endividado (1992). Ou seja, o trabalho perdeu valor frente à capacidade de consumo, a valorização do homem não está mais na sua capacidade de trabalho, mas sim no seu poder de consumo, independentemente de este ser oriundo do suor ou do ócio.

Marx já havia demonstrado preocupação em entender como "se haviam criado condições nas quais o trabalho, de condição natural para a realização do homem, chegara a se tornar o seu algoz" (KONDER, 2009, p. 42), tendo chegado à conclusão de que "a desvalorização do homem aumenta na razão direta da valorização dos objetos" (MARX apud KONDER, Idem, Ibidem).

Assim, nem sociedade sinóptica, nem pós-panóptica ou mesmo de controle, o que temos é uma sociedade tão destituída de humanidade, onde as pessoas são cada vez mais supérfluas, que qualquer tentativa de conceituação seria unilateral e egoísta. Numa sociedade tão superlotada quanto um presídio de terceiro mundo, sem oportunidades de emprego ou de colocação social, as pessoas lutam para permanecerem incluídas, pois qualquer passo em falso, qualquer deslize, gera a exclusão certa: “Os outros não necessitam de você, podem passar muito bem, e até melhor, sem você. Não há uma razão-evidente para você existir nem qualquer justificativa óbvia para que você reivindique o direito à existência" (BAUMAN, 2005, p. 20).

Os que conseguem se manter incluídos agora não encontram mais dignidade no trabalho, porque o que aconteceu foi uma "mercantilização da vida, com todas as suas consequências inumanas" (KONDER, Op. Cit. p. 146). O descarte, a demissão, pode vir a qualquer momento, por ato de um diretor ou de um funcionário qualquer que representem o verdadeiro patrão, também desconhecido. A satisfação está na inclusão pura e simples, em sobreviver à exclusão que cresce a cada dia. 
$\mathrm{O}$ que se disse até aqui se encaixa mais perfeitamente naquele ser humano que se encontra no limiar da exclusão, com a inclusão sempre a vista. Como em uma corda bamba entre a exclusão e a inclusão. Mas a maioria das pessoas no nosso país está bem distante disso, ou seja, são pessoas que têm a inclusão como algo bem distante. Principalmente para essas pessoas o trabalho está longe de ser motivo de qualquer esperança, mas é pura sobrevivência. Nestes casos o pacto social não resguarda nada e, pelo contrário, serve para evidenciar o desrespeito para com o trabalhador.

O aviltamento do seu trabalho é a mais grave ofensa social que possa ser feita a um homem. Ela o atinge na essência mesma de sua condição de pessoa. Ela ofende o seu senso de equidade e de justiça. Ela o frauda na sua esperança - e na sua fé no mundo. Ela semeia em seu coração a descrença e a revolta (PELLEGRINO, 1986, p. 104)

Nesse ambiente não é de se estranhar que o trabalho penitenciário também não tenha mais nenhuma importância, não funcione como mecanismo de ressocialização nem de disciplina. E não há nenhuma iniciativa direcionada para tanto, pois o que se tem no meio carcerário são atividades aleatórias, trabalhos esporádicos que não merecem nem serem chamados de trabalho. Se há algo de terapia em costurar uma bola de futebol, varrer ou limpar a cozinha da penitenciária, tais atividades nunca podem se comparar com algo que possua a capacidade de conferir dignidade a um ser humano.

Muito menos podem tais atividades serem tidas como capazes de permitir qualquer inclusão. O preso já foi incluído na esfera de interesse do Estado, mas pela porta dos fundos, pela porta da mais extrema exclusão.

Quando uma autoridade qualquer fala em ocupar o tempo do preso não é por altruísmo, nem na busca de lhe conceber o mínimo de dignidade, mas pela preocupação com a segurança. No meio carcerário é comum o ditado mente vazia, oficina do diabo. Por isso não importa se o preso está martelando um pedaço de pedra ou montando um complexo produto, porque o trabalho do preso, para o Estado, é somente ingrediente da segurança institucional.

\subsubsection{Trabalho, remição e remuneração}

A redação original do art. 126 da Lei de Execução Penal estabelecia que "o condenado que cumpre pena em regime fechado ou semiaberto poderá remir, pelo trabalho, parte do tempo de execução da pena", completando no $\S 1^{\circ}$ que "a contagem do tempo para o fim deste artigo será feita à razão de 1 (um) dia de pena por 3 (três) dias de trabalho”. 
A Lei 12.433 , de 29 de junho de 2011, reformou a redação do citado artigo para incluir a remição pelo estudo, mas não alterou a regra da remição pelo trabalho que continua sendo de um dia de pena para três dias de trabalho, desta feita regulada pelo inciso II, do $\S 1^{\circ}$, do art. 126 da LEP. A referência acima à norma anterior se dá em virtude do fato de que a jurisprudência analisada a seguir é na sua maioria anterior à reforma da redação do citado artigo.

Resquício ou não de um período em que havia a crença na ressocialização por intermédio do cárcere e do trabalho, a remição está disciplinada em lei. Assim como "constituem direitos do preso: a atribuição de trabalho e sua remuneração" (art. 41, II, da LEP).

O certo seria que tais dispositivos legais fossem analisados pelo judiciário dentro da mais estrita legalidade, garantindo tudo o que for conferido ao preso como sujeito de direitos, lembrando que como tal ele é pessoa que só pode ter atingido o que for expressamente restrito por lei ou pela sentença condenatória. Não obstante, o que acontece é um grande distúrbio causado por ideais de correção que permanecem latentes na mente do juiz, fazendo com que tais direitos sejam relativizados.

Chega a parecer estranho designá-lo como cidadão, mas o preso é um cidadão pagando um alto imposto, a pena criminal. Recolhido e impossibilitado de sair de uma instituição do Estado, não haveria como negar-lhe direitos tão básicos como o de trabalhar e ter sua remuneração. Mas, como alerta César Barros Leal, "é como se todos houvessem firmado um ominoso pacto de silêncio, de conivência com a incúria, com a indiferença. Finge-se não ver o que é visível, ostensivo" (2001, p. 80).

Se não é mais interesse do Estado liberal alcançar o pleno emprego e a inclusão passou a ser o objetivo de cada cidadão considerado individualmente, ao menos quando o Estado assume o encargo de encarcerar um membro da sociedade não poderia haver a possibilidade de descumprimento de norma básica relacionada à dignidade do ser humano.

Entretanto, todos sabemos que esta norma não é cumprida e que não são todos os presos que têm observado o seu direito ao trabalho. Note-se que ainda que o trabalho existente não traga nada de dignidade e que seja visto pelo Estado como questão de segurança, ele é direito do preso. Direito e dever do preso, mas mais direito, porque se engana quem pensa que 
é agradável a um ser humano passar dez, vinte anos numa penitenciária, sem qualquer atividade.

Os presos brigam, matam e vendem a oportunidade de trabalhar no interior do cárcere. Quem trabalha é tido como considerado do diretor ou do xerife da ocasião. E não é em razão da remuneração nem da remição que esse preso é tido como privilegiado, mas em razão de poder mesmo ocupar o seu tempo, além do acesso ao mundo exterior que o trabalho proporciona, podendo inclusive, favorecer interesses escusos dos que continuam envolvidos com o crime do lado de fora.

E olhando por esse prisma, o trabalho do preso pode até parecer um benefício. $\mathrm{O}$ trabalho que era para compor o programa individualizador da pena privativa de liberdade a ser elaborado pela Comissão Técnica de Classificação, na forma do art. $6^{\circ}$ da LEP, acaba sendo atribuído pela equipe de segurança do estabelecimento penal conforme certas diretrizes que ninguém conhece.

Mas abstraindo toda essa aparência de benefício, o trabalho é um direito do preso, assim como é a remuneração e a remição referente a esse trabalho. Não há como inverter as coisas e tratar como benefício um direito só porque esse direito não é concedido a todos os presos. Todavia, há jurisprudência que considera o trabalho penitenciário uma benesse concedida ao preso por parte do Estado:

PRESO. TRABALHO. REMUNERAÇÃO. REMIÇÃO DA PENA. O trabalho do presidiário, voluntário, tem como objetivo exclusivo remir a pena, inexistindo obrigação do Estado em remunerá-lo. Apelação não provida. (20070110532303APC, Relator JAIR SOARES, $6^{\text {a }}$ Turma Cível do Tribunal de Justiça do Distrito Federal, julgado em 30/09/2009, DJ 07/10/2009 p. 194).

CIVIL. AÇÃO DE COBRANÇA. PRESO. TRABALHO NÃO REMUNERADO REALIZADO NO INTERIOR DO ESTABELECIMENTO PRISIONAL. AUSÊNCIA DE CONTRAPRESTAÇÃO PECUNIÁRIA. FINALIDADE. REMIÇÃO E RESSOCIALIZAÇÃO. POSSIBILIDADE.1 - O artigo 28 da Lei de Execução Penal prevê que "o trabalho do condenado, como dever social e condição de dignidade humana, terá finalidade educativa e produtiva". 2 - A interpretação extensiva e analógica do dispositivo que prevê atividades não remuneradas pelo preso (artigo 30 da LEP) deve englobar aquelas exercidas no interior do estabelecimento prisional, com a finalidade única de permitir ao condenado o pleno acesso à remição da pena. 3 - Apelo não provido.(TJDFT -20080110254176APC, 
Relator CRUZ MACEDO, 4a Turma Cível, julgado em 11/03/2009, DJ 01/04/2009 p. 64) ${ }^{130}$.

A ginástica hermenêutica feita pelo Tribunal do Distrito Federal ${ }^{131}$ impressiona, pois fez tábula rasa da norma que garante ao preso o trabalho e a equivalente remuneração, com base em regra que diz que a pena restritiva de direitos de prestação de serviços à comunidade não é remunerada (art. 30 da LEP), em uma interpretação analógica evidentemente prejudicial.

As decisões em comento permitem análise sob vários ângulos. Primeiramente são decisões de juízos cíveis que desconsideram a diferença entre a prestação de serviços à comunidade, realizada em liberdade, e o trabalho intramuros que deve ser proporcionado pelo Estado, estando o preso em situação evidentemente inferior nesta relação. Não interessa se o julgador tem formação cível ou criminal, o trabalho penitenciário deve ser julgado como tal e, negar a equivalente remuneração é agravar a pena ilegalmente, criar um sofrimento extra que não está previsto em lei.

Se o trabalho e a remuneração por lei fazem parte da pena, e o princípio da legalidade veio para garantir todos os direitos do preso não atingidos pela lei ou pela sentença, a analogia feita na decisão acima é absolutamente violadora do princípio da legalidade.

Outra questão que vem à tona é a relação feita do trabalho com a ressocialização, como se esta fosse um benefício por si só, e fosse alcançada pelo simples fato de se estar ocupando o tempo do preso. Age-se como se a remuneração do trabalho não fizesse parte do ideal de ressocialização presente na mente do legislador. Tanto fez parte desse ideal que boa parte dessa remuneração não serve imediatamente ao preso, mas deve constituir um pecúlio a fim de lhe ser entregue somente quando em liberdade (art. 29, $\S 2^{\circ}$, da LEP).

Se ressocialização é o aprendizado de novos valores, a decisão que nega o direito do preso a receber remuneração pelo trabalho realizado no interior de uma instituição estatal está

\footnotetext{
${ }^{130}$ No mesmo sentido, de que não há obrigação de se pagar remuneração ao preso por se entender que o trabalho é um benefício, outras decisões do TJDFT: TJDFT- 20070111086353RMO, Relator SÉRGIO BITTENCOURT, $4^{\mathrm{a}}$ Turma Cível, julgado em 24/02/2010, DJ 15/03/2010 p. 111; APC 20070110468660, Rel. JAIR SOARES, $6^{\mathrm{a}}$ Turma Cível, julgado em 12/01/2011, DJ 17/01/2011 p. 124; APC 20070110733819, Relator JAIR SOARES, $6^{\mathrm{a}}$ Turma Cível, julgado em 01/04/2009, DJ 22/04/2009 p. 166.

${ }^{131}$ Nucci traz decisões do Tribunal de Justiça de São Paulo sobre remição que indica a aceitação desse tribunal de trabalho sem remuneração: "Qualquer trabalho pode dar remição, mesmo faxineiro, sem remuneração ou previdência social (Ag. 112.124.3-Poá, rel. Sinésio de Souza, 30.03.1992, v.u.; Ag. 161.534.3-Bauru, rel. Denser de Sá, 18.08.1994)" (2009-a).
} 
ensinando os piores valores possíveis, por isso não podemos resistir e não citar texto de Joaquim Nabuco de 1873:

O que esse regime representa, já o sabemos. Moralmente é a destruição de todos os princípios e fundamentos da moralidade religiosa ou positiva - a família, a propriedade, a solidariedade social, a aspiração humanitária: politicamente, é o servilismo, a degradação do povo, a doença do funcionalismo, o enfraquecimento do amor da pátria (2000, p. 164).

Não é exagero recorrer ao grande abolicionista. O preso está sob um regime penitenciário que nada mais é que um regime de vida ${ }^{132}$, o qual por lei deve regular o seu dia, seus horários, seu contato com o mundo exterior, todas as suas atividades, sua possibilidade de relação sexual e até o tempo em que poderá ver o sol. Submetê-lo ou mesmo possibilitar que este se submeta a um regime de vida que inclui trabalho sem remuneração não é só ilegal, é criminoso.

Janaína Paschoal, ao lembrar o evidente fato de que o trabalho remunerado constitui um direito do preso, faz a mesma comparação: "além disso, nunca é demais reforçar o fato de a escravidão haver sido, ainda que tardiamente, abolida" (2003, p. 110).

Deve-se lembrar que, na história da humanidade, o preso das decisões citadas está em pior situação que o escravo da antiguidade, pois estes tinham direito ao peculium (e não deve ser coincidência a semelhança com a palavra que significa a remuneração do preso prevista em lei hoje em dia), que abrangia "as posses privadas de um escravo" (ARENDT, 2010, p. 76). Com a negação de pecúlio ao preso é inevitável que não venha à mente o verso do grupo musical O Rappa de que todo camburão tem um pouco de navio negreiro.

Indiferente a questão de raça nesse tipo de escravidão, por que o outro sempre pôde ser escravizado. Os ideais e avanços políticos na seara dos direitos humanos, pelo visto, não têm impedido tenhamos em pleno Século XXI decisões que ainda aceitem a possibilidade da existência de um trabalho sem remuneração.

Roberto Romano, dando exemplo de manifestações racistas nas primeiras doutrinas liberais, que pavimentam até hoje a consciência moderna com ideias de exclusão, ao se referir

\footnotetext{
${ }^{132}$ Para Zaffaroni e Nilo Batista, "a execução da sentença condenatória penal implica a gestão concreta de uma pessoa que tem necessidades fisiológicas, afetivas, intelectuais e sociais próprias, de acordo com suas reais características e que se vivenciam em um projeto existencial que envolve o tempo como essência (2006, p. 295).
} 
a texto de John Locke, expõe claramente que em uma sociedade onde a propriedade é o valor de maior relevância, aquele que não é proprietário pode vir a ser considerado "fera" e assim ser posto "a serviço dos que são iguais entre si. O escravo pode possuir qualquer pigmentação da pele: basta que ele tenha atentado, ou possa vir a atentar, em algum momento, contra a propriedade, a marca humana dos 'homens bons', para ser reduzido ao status de não homem" (2001, p. 125).

Importa fazer referência igualmente ao trabalho da professora de Ohio, nos Estados Unidos, Michelle Alexander, denominado The New Jim Crow (2012). Em tal obra se levanta a hipótese, de maneira extremamente fundamentada, de funcionar o encarceramento em massa norte-americano como um sistema de controle da população negra, que teria vindo em substituição à escravidão e ao antigo sistema Jim Crow, o qual permitia aos Estados, após abolido o sistema escravagista, criarem leis de segregação e separação dos negros em cinemas, teatros restaurantes etc.

A título de ilustração, interessante trazer jurisprudência colhida no trabalho citado, sobre a visão que se tinha do preso, retirada do caso Ruffin v. Commonwealth, de 1871. A sinceridade de outrora, comparada com os subterfúgios ideológicos de hoje, não impede que percebamos grande similitude na forma de se tratar o preso como objeto do Estado:

Por um tempo, durante o serviço penitenciário, ele está em estado de servidão penal em benefício do Estado. Ele tem, como consequência de seu crime, não somente a perda da liberdade, mas de todos os direitos pessoais, excetos aqueles em que a lei, em sua humanidade, permitir. Ele é temporariamente um escravo do Estado. Ele é um morto civil; e seu estado, se ele tem algum, é administrado como o de um homem morto $^{133}$ (Apud ALEXANDER, 2012, p. 31).

A remuneração pelo trabalho do preso era reivindicação no século XVIII. Howard já defendia que o trabalho do preso fosse o mais semelhante possível ao realizado em liberdade. Passaram-se anos, conquistas foram feitas, homens morreram, para que a remuneração do

\footnotetext{
${ }^{133}$ No original: "For a time, during his service in the penitentiary, he is a state of penal servitude to the State. He has, as a consequence of his crime, not only forfeited his liberty, but all his personal rights except those which the law in its humanity accords to him. He is for the time being a slave of the State. He is civiliter mortus; and his estate, if he has any, is administered like that of a dead man" (Apud ALEXANDER, 2012, p 31)
} 
preso fosse positivada na legislação. Entretanto agora, o mesmo argumento que viabilizou um direito, volta para suprimi-lo. Difícil realmente considerar o preso um sujeito de direitos, pois todos os sentimentos que proporcionam tal descaso para com esse ser humano são tão fortes, a ponto de se rasgarem constituições e leis.

Há os casos dos presos provisórios, estes que não são obrigados a trabalhar, mas possuem o direito para tanto (art. $2^{\circ}$, parágrafo único, e 31, parágrafo único, da LEP). Nem nessas circunstâncias se pode negar o direito à remuneração do preso ${ }^{134}$. Se o trabalho do preso também é um dever social do Estado (art. 28 da LEP), não se pode conceber seja gratuito, porque, caso contrário, de social nada teria. A remuneração é um direito de qualquer cidadão preso.

Goste ou não o tribunal, é a lei. "No momento em que o estado assumiu o encargo de administrar justiça, substituindo-se ao particular, investiu-se também da responsabilidade de respeitar a lei por ele mesmo - Estado - editada. Com todos os seus consectários" (NALINI, 1998, pp. 142-143).

E nem se diga que excluído o pensamento ressocializador, o trabalho do preso, a remuneração e a remição poderiam ser abolidas como direitos. Não é o caso. Todos são direitos inerentes à dignidade da pessoa humana. A remição com o tempo vem sendo considerada mais uma medida descarcerizadora do que ressocializadora, tanto que a jurisprudência veio relativizando o rigor e cada vez mais considerando outras atividades, que não apenas o trabalho, passíveis de remição, como é o caso do estudo ${ }^{135}$. Foi a força da prática jurisdicional que permitiu a alteração legal ocorrida com a Lei 12.433/11, reformuladora da redação do art. 126 da LEP, passando a prever a possibilidade da remição pelo estudo ainda que seja para os presos que não trabalhem e somente estudem.

\footnotetext{
${ }^{134}$ Em Cezar Roberto Bitencourt: “O condenado por crime político não está obrigado ao trabalho (art. 200 da LEP), nem o preso provisório (art. 31, parágrafo único, da LEP), mas, se trabalharem, terão os mesmos direitos dos demais presos" (2009, p. 503).

${ }^{135}$ Súmula 341 do STJ: "A freqüência a curso de ensino formal é causa de remição de parte do tempo de execução de pena sob regime fechado ou semi-aberto". Há notícia em outros países, como no México e na Colômbia, da extensão do direito à remição às atividades desportivas e artísticas (LAURIA; VALOIS, 2009).
} 
Qualquer medida descarcerizadora vem a favor tanto da dignidade da pessoa humana quanto do princípio da legalidade, visto que a realidade do sistema penitenciário é um testemunho direto de desrespeito a ambas, à dignidade e à legalidade.

\subsubsection{Remição: direito ou fiç̧ão?}

Em complemento à norma que concede direito ao preso de remir um dia de pena por três dias de trabalho, o art. 126 da LEP, no $\S 4^{\circ}$, estipula que o preso impossibilitado de prosseguir no trabalho, por acidente, continuará a beneficiar-se com a remição ${ }^{136}$.

O legislador, autor da Lei de Execução Penal, não pensou numa lei qualquer, como muitas dessas elaboradas fora de contexto e destoantes do resto do ordenamento jurídico. A LEP é um sistema montado que não podia, sendo uma lei, prever o seu próprio descumprimento. Por isso que não há previsão para a balbúrdia que é o nosso sistema penitenciário.

$\mathrm{Na}$ LEP não há previsão para preso ficar recolhido em container $^{137}$, os presos provisórios devem ficar em cadeias públicas e não em delegacias, os condenados de regime fechado em penitenciárias e os de regime semiaberto em colônias agrícolas ou industriais, seguindo por aí a estrutura montada pelo legislador para o sistema. Embora saibamos ser uma legislação que está longe de se efetivar, é uma lei e, como tal, deve ser respeitada, merecendo a interpretação que mais se adeque à realidade.

Portanto, quando o legislador previu que o preso sem condições de prosseguir no trabalho, por acidente, continuaria a beneficiar-se com a remição, assim o fez porque somente por acidente ele não poderia prosseguir no trabalho, salvo hipótese de o preso negar-se ao

\footnotetext{
${ }^{136}$ Tal disposição estava, antes da Lei $12.433 / 11$, no $\S 2^{\circ}$ do mesmo artigo, com a seguinte redação: "O preso impossibilitado de prosseguir no trabalho, por acidente, continuará a beneficiar-se com a remição"; Atualmente tal regra encontra-se no $\S 4^{\circ}$ da seguinte forma: "O preso impossibilitado, por acidente, de prosseguir no trabalho ou nos estudos continuará a beneficiar-se com a remição".

${ }^{137}$ No ano de 2009, ganhou destaque internacional a denúncia de Salomão Shecaira, quando presidente do Conselho Nacional de Política Criminal e Penitenciária, à Organização das Nações Unidas de que havia cerca de 430 presos em 14 contêineres mantidos em centros de detenção do governo do Estado do Espírito Santo. Disponível em <www.ibccrim.org.br/site/noticias/conteudo.php?not_id=13497>. Acesso em 26 jan 2011.
} 
trabalho, situação que se constituiria em falta grave (art. 39, V c/c art. Art. 50, VI, da LEP), passível de isolamento.

A interpretação é lógica, porque sendo, e não se deve cansar de repetir, o trabalho um direito do preso (art. 41, II, da LEP) e um dever do Estado (art. 28 da LEP), o legislador não poderia prever que nossos estabelecimentos penais não tivessem trabalho para todos os presos, nem que o seu conceito de trabalho iria permitir que presos pudessem exercer atividades gratuitas e muito menos que essas parcas atividades que surgem fossem distribuídas por critérios obscuros. A objetividade da lei não permite concessões com a ilegalidade.

$\mathrm{Na}$ letra da lei não há a hipótese de não ser disponibilizado trabalho para o preso, portanto a lei previu que caso haja um acidente e este preso não possa prosseguir no trabalho, esta situação não poderia prejudicá-lo também com a impossibilidade de obter a remição e a consequente diminuição da pena.

Não obstante, a precária realidade do sistema faz com que não sejam os presos que sofrem acidentes os únicos a ficarem impossibilitados de trabalhar. Inúmeros outros estão na mesma situação, impossibilitados de trabalhar porque o Estado não thes permite exercer o direito de trabalhar. Portanto, nada mais justo que a este preso que não tem podido trabalhar por omissão do Estado também seja deferida a remição.

A doutrina costuma dar a isso o nome de remição ficta, criando desde o começo uma designação pejorativa para um direito do cidadão preso. Aos danos morais que a classe média brasileira tem se acostumado não foi dado o nome de dano ficto; o ganho salarial a mais e o dobro de dias que juízes e promotores têm a título de férias não se chamam ganhos fíctícios; a sombria CPMF jamais ganhou algo de fictício no nome; a restituição em dobro ao consumidor pela cobrança indevida também não é ganho ficto. Mas quando o preso tem expressamente o direito de trabalhar e de remir parte de sua pena e o próprio Estado não lhe permite usufruir desse direito, a pretensão de obtê-lo é chamada de remição fícta.

Nenhum direito é ficto. O trabalho do preso e a consequente remição são direitos materiais, relacionados à sanção legalmente estabelecida pelo Estado. Se o judiciário não consegue intervir para determinar que todos os presos possam trabalhar, visto que a divisão de poderes e a própria limitação legislativa não lhe permite muito nesse campo, a remição pode 
ser concedida. Ficta ou não, deveria ser concedida. A jurisprudência negando tal direito é farta e assim como nas questões anteriormente tratadas volta à baila o espectro da ressocialização como fundamento para se tolher direito do preso. Não só especificamente este argumento, a jurisprudência também tem usado outros, mas sempre girando em torno do princípio de uma execução penal ressocializadora.

O mesmo ruído interpretativo acontece na doutrina, mas felizmente há doutrinadores firmes em reconhecer que "se ele tem direito ao trabalho e se o Estado não oferece condições para seu efetivo exercício, o condenado não pode arcar com a incúria do Estado" (SHECAIRA, CORRÊA JÚNIOR, 1995, p. 337). Entre os doutrinadores contrários à remição poderemos encontrar os argumentos que surgem em oposição a este direito de forma mais sistematizada, todavia começaremos examinando a jurisprudência:

AGRAVO EM EXECUÇÃO. REMIÇÃO. REQUISITOS. COMPROVAÇÃO DO EFETIVO TRABALHO. CONTAGEM DOS DIAS TRABALHADOS. DECISÃO REFORMADA. - A diminuição da pena na fase executiva por força da remição pelo trabalho tem como escopo a (re)integração social do condenado. Em sendo assim, a toda evidência, somente se justifica se lastreada em efetivo desempenho de atividade laboral. Conceder a remição sem a efetiva contraprestação do trabalho, tão-somente porque ao apenado não foi oportunizada melhor condição para o seu desempenho (fornecimento de material), é reconhecer a existência de um dever do Estado de atribuir trabalho ao condenado, entendimento que não se coaduna com a orientação predominante nos Tribunais pátrios. Agravo em Execução provido. (Ag. $\mathrm{n}^{\circ}$ 70034335752, $8^{\text {a }}$ Cam. Crim., Tribunal de Justiça do RS, Relator: Dálvio Leite Dias Teixeira, J. em 17/03/2010).

Realmente o dever do Estado em atribuir trabalho ao condenado não vem de um entendimento que segue a orientação dos tribunais, mas é tão somente um direito que está na lei, apenas isso. Temos aqui uma entre tantas outras decisões que desconsideram o direito do preso ao trabalho e à remição ${ }^{138}$, sendo esta um exemplo perfeito do que já se disse, de que uma mentira contada mil vezes torna-se uma verdade. O que interessa, no caso, não é o direito

\footnotetext{
${ }^{138}$ Exemplos de decisões que seguem no sentido de que o trabalho do preso não é um direito para negar a remição: TJ-SP, 5a Cam. Crim., Ag. $\mathrm{n}^{\mathrm{o}}$ 9185890-15.2007.8.26.0000, Rel. Des. Pinheiro Franco, j. em 27/09/2007; Ag. no 9208645-33.2007.8.26.0000, Rel. Tristão Ribeiro, j. em 22/11/2007 - TJ-GO, $2^{\text {a }}$ Cam. Crim., Ag. 200502161293, Rel. Des. José Lenar de Melo Bandeira, DJ de 02/02/2006 - TJ-RJ, $2^{\text {a }}$ Cam. Crim., Ag. ${ }^{\circ}$ 0036998-55.2006.8.19.0000 (2006.076.00037), Des. Rel. J.C. Murta Ribeiro, j. em 11/07/2006; 5 Cam. Crim., Ag. ${ }^{\circ}$ 0035705-84.2005.8.19.0000 (2005.076.00148), Des. Rel. Silvio Teixeira, j. em 06/12/2005 - TRF $1^{\circ}$ Região: AGEPN 2010.41.00.001769-1/RO, Rel. Des. Federal Hilton Queiroz, $4^{\text {a }}$ Turma,e-DJF1 p.31 de 22/09/2010; AGEPN 0004179-79.2010.4.01.4100/RO, Rel. Juiz Tourinho Neto, $3^{\text {a }}$ Turma,e-DJF1 p.42 de 11/06/2010; HC 2003.01.00.014687-0/MG, Rel. Des. Federal Mário César Ribeiro, $4^{\mathrm{a}}$ Turma,DJ p.16 de $02 / 02 / 2004$.
} 
do preso, mas seguir o entendimento dos tribunais pátrios. Aí se formam aqueles juízes despersonalizados que Nelson Hungria descreveu como reduzidos "ao humilde papel de esponja, que só restitui a água que absorve" (1977, p.79). Sim, claro, porque os tribunais devem, absolutamente, estar certos, pois nunca iriam negar um direito para um cidadão, só porque ele está preso.

Em verdade, os tribunais acabam se transformando em mais um braço militar do Estado, que nega permanentemente uma quantidade enorme de direitos à pessoa presa, assim como avaliza um sem número de inquéritos policiais irregulares, compactua com invasões de residências em favelas, tudo em nome da segurança, não a segurança jurídica, mas a segurança social. Esta segurança não chegou nem perto de alcançar os ideais do positivismo lombrosiano, mas se contenta em ser apenas uma capenga segurança militar, voltada contra muitos e em favor de poucos.

O julgador acredita, ou alega acreditar, que a ressocialização se dá pelo trabalho e como não houve o efetivo exercício de atividade laboral, o preso não teria direito à remição, ou seja, para o judiciário, o preso não tem direito à remição porque não se ressocializou. Uma interpretação que desconhece a realidade do trabalho penitenciário, o qual, como já dissemos, é somente uma ocupação muitas vezes até mesmo relacionada a atividades que poderiam ser consideradas o oposto dos valores ligados ao que se pretende seja a ressocialização.

São favoráveis a que se conceda a remição ao preso impossibilitado de trabalhar, além de Shecaira e Corrêa Júnior (1995), Mirabete, o qual cita Maurício Kuehne, Rui Alvim e Thaumaturgo Filho com o mesmo entendimento (1997), além de Rogério Greco (2009), João José Leal (1998), Cândido Furtado Maia Neto (1998), Sidnei Agostinho Beneti (1996) e Fernando Galvão da Rocha (2007).

São contrários à remição como um direito do preso, mesmo diante da inércia do Estado, Guilherme de Souza Nucci (2009-a), Jason Albergaria (1996), Cezar Roberto Bitencourt (2009), René Ariel Dotti (2001), Osni Souza (1998), Renato Marcão (2007), Haroldo Caetano da Silva (2006) Paulo Fernando dos Santos (1999) e Paulo José da Costa Júnior, no sentido de que "a efetiva prestação de trabalho é pressuposto indispensável à remição" (2009, p. 169). Doutrinadores que, em sua maioria, dão ênfase ao caráter 
ressocializador da pena privativa de liberdade e afastam a consideração do trabalho do preso como direito, para incluí-lo em um duvidoso índice de ressocialização.

Albergaria (1996), embora reconheça o caráter de alternativa penal à remição, partindo de uma concepção consensual, redobra o caráter ressocializador da remição. Neste caso, para o autor, a remição só poderia ser concedida se comprovados indícios de ressocialização demonstrassem que a medida é indicada. Uma amostra evidente de que os ideais de ressocialização são incompatíveis com a certeza do princípio da legalidade.

Contudo, é Dotti quem melhor resume os argumentos contrários à remição na ausência de trabalho, no que ele considera "obstáculos que se opõem a essa 'liberalidade"” (2001, p. 608), e entre esses obstáculos estão:

“a) concede igual benefício para quem trabalha e quem não trabalha; b) nega vigência à regra do devido procedimento legal que dispõe sobre a contagem dos dias trabalhados (LEP, art. 129); c) descaracteriza um dos efeitos da punição pela falta grave (LEP, art. 127); d) estimula a prática oficial dos delitos de prevaricação e falsidade ideológica" (Idem, Ibidem).

Com todo respeito ao eminente professor Dotti, liberalidade é o que acontece de abandono e descaso para com o sistema penitenciário. Não pode ser liberalidade um direito previsto em lei que deveria ser concedido se o judiciário percebesse que ele está entre o preso e a administração penitenciária, e não ao lado do serviço de segurança do Estado.

Embora nosso objetivo seja o exame da jurisprudência e não a crítica à doutrina, podemos partir dos argumentos acima descritos, porque são o substrato do que se alega jurisprudencialmente. O primeiro item vem, nas decisões dos tribunais, como uma violação ao princípio da isonomia, caso em que, se concedida a remição ao preso que não trabalha haveria um tratamento desigual, porque se estaria dando o mesmo tratamento ao preso que trabalha e ao que não trabalha.

Veja-se que se parte do pressuposto de que o trabalho e a remição são benefícios e não direitos e, então, não haveria como beneficiar quem não merece. $\mathrm{O}$ merecimento entra pois como requisito essencial do processo ressocializador, onde os direitos não são avaliados objetivamente. É o fundamento da decisão acima examinada, por isso reforçaremos o que foi dito. 
Em termos de sentimento, e não de direito, onde se insere a questão do merecimento, o preso que trabalha já está se sentindo beneficiado só por trabalhar e poder ocupar o seu tempo, sendo a remição uma consequência. E o preso que não trabalha está sentindo violado o seu direito de igualdade com os demais só por não trabalhar, independentemente da remição que não lhe é concedida. Por isso, dizer que não se deve conceder remição ao preso que não trabalha, porque se estaria dando direito igual ao que trabalha, é punir duas vezes o preso que não trabalha, negando-lhe o direito ao trabalho e o direito à remição.

A jurisprudência denomina de violação ao princípio da isonomia este fundamento para se negar o direito à remição. Ora, a isonomia está sendo violada pelo Estado, quando este oferece ou permite que uns presos trabalhem e outros não, sendo essa quebra de isonomia potencializada pela perda do direito à remição que os presos impedidos de trabalhar sofrem. Não se pode conceder direitos iguais aos que têm tratamento desigual, isto sim é um princípio básico de efetivação do princípio da isonomia.

Como exemplo de jurisprudência que se baseia nesse parcial princípio da isonomia:

\begin{abstract}
RECURSO DE AGRAVO - EXECUÇÃO PENAL - PEDIDO DE REMIÇÃO DE PENA POR TRABALHO NÃO EXECUTADO - OMISSÃO DO ESTADO EM NÃO OFERECER CONDIÇÕES PARA O TRABALHO - HIPÓTESE DE REMIÇÃO FICTA - INADMISSIBILIDADE - AFRONTA AO PRINCÍPIO DA ISONOMIA - RECURSO IMPROVIDO. (...) A par de judiciosos entendimentos em sentido contrário, inadmito a hipótese de remição ficta, uma vez que a remição de parte do tempo de execução da pena pelo trabalho exige o efetivo exercício de atividade laborativa pelo sentenciado (art. 126 da LEP). Indubitável que o reeducando pudesse estar pessoalmente predisposto à atividade laboral - que, de mais a mais, constitui um dos principais instrumentos de ressocialização. No entanto, o direito subjetivo só surge diante da oportunidade de trabalho criada e oferecida pelo Estado, diga-se de passagem, Poder Executivo, cuja eventual omissão, embora seja socialmente condenável e esteja em descompasso com os princípios da LEP, não pode dar margem a que o Judiciário conceda remição fora das hipóteses legais, afrontando aqueles que, de fato, trabalham ou estudaram para fazer jus ao benefício (princípio da isonomia) (...). (TJ-MG, $1^{\text {a }}$ Cam. Crim., Ag. 1.0000.08.476837-3/001, Rel. Des. Edelberto Santiago, j. em 19/08/2008) ${ }^{139}$.(Grifei)
\end{abstract}

Como se pode observar, no final do texto, o princípio da isonomia vem para não afrontar aqueles que, de fato, trabalharam, em um total desconhecimento da realidade carcerária. Da mesma forma, revelador o fato de o judiciário estar julgando contra uma

\footnotetext{
${ }^{139}$ Decisões no mesmo sentido: TJ-MG, $1^{\text {a }}$ Cam. Crim., Ag. ${ }^{\circ}$. 1.0000.08.476837-3/001, Rel. Des. Edelberto

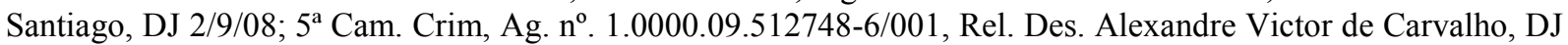

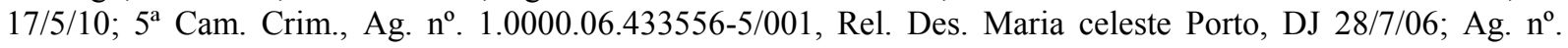
2.0000.00.408467-5/000, Rel. Des. Antônio Armando dos Santos, DJ 23/12/2003
} 
demanda de um preso (cidadão?), prejudicado pela inércia do Estado, e na decisão vir palavras e frases como remição ficta (direito ficto), reeducando, ressocialização, eventual omissão do Poder Executivo, beneficio e isonomia.

A situação é grave quando, em um Estado Democrático de Direito, uma pessoa, só porque foi vencida em uma ação penal, após o contraditório e a ampla defesa, passa a ser considerada desajustada, carecedora de tratamento ressocializador e de benefícios do Estado, sem direitos, mas só deveres inerentes à sua qualidade de reeducando. Um judiciário mais lombrosiano impossível.

É decisão que só demonstra o acerto da hipótese deste trabalho, pois retirado o termo ressocialização dessa hermenêutica e substituído pelo termo dignidade humana, o resultado da decisão seria outro. O respeito ao princípio da legalidade se imporia e todos os outros argumentos não resistiriam. Não haveria reeducando nem benefício, e a omissão do Poder Executivo poderia ser reparada ao menos em parte, concedendo-se a remição negada ao preso.

Como pode o direito querer ser ressocializador ou ao menos comunicativo, para não se tornar arbítrio puro, se palavras totalmente desvinculadas da realidade são usadas para agravar a pena de um preso, presumidamente sujeito de direitos? Este nunca irá entender que o judiciário, representante e guardião do que a população entende por justiça, está a lhe negar direitos previstos em lei sob o argumento de que o direito não lhe pode ser concedido porque outro direito também não lhe foi disponibilizado. Pior fica para entender a isonomia, visto que no interior do cárcere, os presos sentem que os que trabalham são beneficiados duas vezes.

Renato Marcão, em sua obra, traz uma visão geral da jurisprudência sobre o assunto e cita julgado do Tribunal de Justiça de São Paulo (Ag. 187.892/3, 3 ${ }^{\text {a }}$ CCrim. rel. Des. Gonçalves Nogueira, j. em 4-9-95), comumente usado em votos contrários à remição do preso impossibilitado de trabalhar, cujo julgado menciona que se deve "antes, atentar que o condenado que está em débito com a sociedade e, por isso, deve arcar com todas as consequências de sua conduta delinquencial, inclusive aquelas que lhe decorrem à conta de eventuais falhas e lacunas da estrutura penitenciária atual" (2007, p. 174).

O sentimento de vingança não poderia estar mais exposto. Na visão acima, o judiciário é o verdadeiro vingador da sociedade e um vingador eterno, porque depois da condenação e da 
pena aplicada por sentença, o cidadão condenado continua em débito e pode ser punido aleatoriamente independente da pena prevista legalmente. Difícil perceber que o condenado também faz parte dessa sociedade e que o Estado só poderia exigir o cumprimento da lei, ou do débito, se também cumprisse a lei.

Quanto ao argumento que leva a letra $c$, apresentado por Dotti, de que a concessão de remição para o preso que não trabalha descaracterizaria os efeitos da punição por falta grave, trata-se de raciocínio que se pode combater com os mesmos argumentos ressocializadores, visto que não tendo o seu tempo de pena remido como os demais presos privilegiados com a obtenção do trabalho, o preso prejudicado não teria qualquer estímulo ao bom comportamento, pois nada teria a perder em virtude de uma eventual falta grave. A remição não é só uma medida penal descarcerizadora, mas nasceu do ideal de ressocialização, e por isso a Lei de Execução Penal sempre determinou que em caso de falta grave o preso perdesse dias remidos (art. 127) ${ }^{140}$, e sendo assim, o preso já preterido no direito ao trabalho não terá nenhum estímulo, nem oportunidades para um bom comportamento. Dentro da visão ressocializadora da pena, a concessão de remição igualaria o valor da disciplina para todos os presos.

Quanto aos demais fundamentos para se negar o direito em questão, nas letras $b$ e $d$, de que se estaria negando vigência à regra do devido processo legal sobre a contagem dos dias remidos e de que se estaria estimulando a prática oficial dos delitos de prevaricação e falsidade ideológica, entendemos que ambas as alegações são afastadas com um só argumento, a respeito do qual já falamos.

Se conceder o direito à remição, como consequência natural do direito ao trabalho que foi negado ao preso, fosse ofender o devido processo legal, a própria lei não preveria a possibilidade de que a remição fosse concedida em outra situação em que o preso não tem possibilidade de trabalhar, quando no caso de acidente (art. 126, $\S 2^{\circ}$, da LEP). Ora, o que a lei não poderia prever era justamente o seu não cumprimento, cabendo aqui perfeitamente

\footnotetext{
${ }^{140} \mathrm{Na}$ atual redação do art. 127, dada pela Lei 12.433/11, o procedimento para a perda dos dias remidos tornou-se mais justo, visto que o magistrado passa a vincular tal perda à falta disciplinar cometida, ou seja, a perda dos dias remidos deve ser proporcional à falta grave. No caso, o preso não perderá mais todos os dias remidos, como na redação anterior. (art. 127 com a redação dada pela Lei 12.433/11: "Em caso de falta grave, o juiz poderá revogar até $1 / 3$ (um terço) do tempo remido, observado o disposto no art. 57, recomeçando a contagem a partir da infração disciplinar").
} 
verificar a igualdade de tratamento de presos que não podem trabalhar por circunstâncias alheias às suas vontades.

O mesmo vale para a afirmação de que conceder remição nessas hipóteses é cometer prevaricação ou falsidade ideológica, pois se assim fosse, a própria lei não permitiria que se concedesse remição nos casos de acidente. A lei assim procede porque aqui estamos na esfera da diminuição de danos pelo direito que não pode ser usufruído, uma garantia a ser observada pelo judiciário e não um procedimento administrativo. A remição que se deve garantir ao preso não será oriunda de certidões emitidas pelo diretor e calculadas na respectiva vara de execução, não é isso que se quer. Pede-se é que o judiciário conceda a remição como direito material, inerente à pena à qual o cidadão foi condenado, determinando o competente abatimento, um direito seu, afastada qualquer ilusão ressocializadora como fim dessa remição, ou do trabalho que lhe foi negado.

Para finalizar, há o argumento, mais obscuro, de natureza política, ouvido entre os juízes, de que concedendo a remição ao preso que não trabalha, estar-se-á estimulando o Estado a não mais disponibilizar trabalho. O desprezo para com o preso está sempre em conjunto com o sentimento de mais punição, em uma espécie de movimento lei e ordem ${ }^{141}$ articulado desde a base, com o policial que prende, até o juiz que julga; assim, sempre alguém quer dar a sua contribuição de sofrimento à pena do condenado. Por isso, é uma visão obliqua esta de que conceder a remição deixará o administrador acomodado, uma vez que nessa corrente punitiva os administradores ficam mais satisfeitos com a não concessão da remição do que incomodados.

Em outras palavras, a se seguir o raciocínio utilitarista de forçar o Estado a cumprir o seu dever de forma transversa, conceder a remição aos presos que são impossibilitados de trabalhar por omissão do Estado acarretaria o efeito inverso da acomodação. Neste caso, diante do sentimento de mais punição, vendo que o preso estava sendo beneficiado com a

\footnotetext{
${ }^{141} \mathrm{O}$ movimento lei e ordem (Law-and-Order) como algo articulado nasceu nas administrações norte-americanas de Reagan e Bush, embora desde 1965, no governo de Lyndon Jonhson, já se falasse de guerra contra o crime. Com Reagan e Bush, todavia, a guerra foi mais intensa, baseada na lógica de que mais punição e mais encarceramento poderiam diminuir a criminalidade. Contudo, apesar do fracasso da tática política, os princípios de guerra do lei e ordem permaneceram enraizados no judiciário, e nas instituições do sistema penal como um todo, ao ponto de se taxar quem não segue o movimento de rigor punitivo como "being soft on crime" (BLOMBERG; LUCKEN, 2010, p. 185), ou seja, indulgente com a criminalidade.
} 
remição sem trabalho, só restaria ao Estado efetivamente disponibilizar trabalho. Mas isso nada mais é do que conjectura, pois o trabalho do preso e a consequente remição são direitos a serem garantidos pelo judiciário que, se não pode tornar efetivamente disponível o trabalho ao preso, pode conceder-lhe a remição.

\subsection{4 Últimas considerações sobre a remição}

Vimos, então, jurisprudência negando o direito à remuneração, mesmo sabendo ter o preso trabalhado em uma instituição pública, a prisão, mas lhe permitindo a remição. Depois vimos jurisprudência que nega o direito à remição ao preso que não trabalhou, apesar de ter direito a uma ocupação no interior do estabelecimento penal. Todas decisões que usaram o termo ressocialização para negar direitos em prol de maior tempo de cárcere. Há ainda posicionamento mais grave, que nega o direito à remição e à remuneração, mesmo sabendo que o preso exerceu atividades intramuros:

HABEAS CORPUS. EXECUÇÃO PENAL. REMIÇÃO. ARTESANATO. LIMPEZA DA PRÓPRIA CELA. IMPOSSIBILIDADE. AUSÊNCIA DE COMPROVAÇÃO DO CONTROLE SOBRE AS ATIVIDADES E PERÍODOS SUPOSTAMENTE TRABALHADOS. WRIT DENEGADO. 1. Para fins de remição, é indispensável a comprovação do órgão da execução penal, a respeito das especificidades das atividades desempenhadas, seus horários e seu papel ressocializador. 2. Writ denegado. (STJ, 6 $6^{\mathrm{a}}$ Turma, HC n ${ }^{\circ}$ 116.840/MG, Rel. Min. Jane Silva (Desembargadora do TJMG convocada), j. em 06/02/2009).

Não é majoritário o posicionamento acima expresso ${ }^{142}$, contudo vale a citação, pois oriundo de uma das cortes superiores do país. No caso da decisão trazida à colação, o fundamento principal é o de que as atividades do preso não foram devidamente acompanhadas pelo órgão da execução, sem que se pudesse comprová-las, situação evidentemente que não diz respeito ao preso. $\mathrm{O}$ outro argumento que chama a atenção é o de que a atividade desempenhada deve ter papel ressocializador, afastando do direito à remição tanto o trabalho de limpeza quanto o artesanato.

\footnotetext{
${ }^{142}$ Em sentido contrário à decisão do STJ: TJSP, $1^{\text {a }}$ Cam. Crim., Ag. Ex. 0352638-88.2010.8.26.0000, Rel. Des.

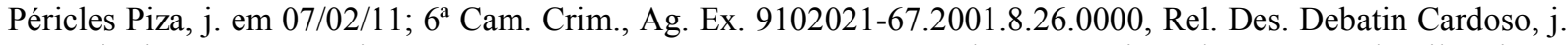
em 21/01/03; $5^{\text {a }}$ Cam. Crim., Ag. Ex. 903487-63.1999.8.26.0000, Rel. Des. Luzia Galvão Lopes da Silva, j. em 16/02/01 - TJMG, $2^{\text {a }}$ Cam. Crim., Ag. Ex. 1.0042.04.006085-9/001, Rel. Des. Reynaldo Ximenes Carneiro, j. em 24/06/04; $1^{\text {a }}$ Cam. Crim., Agr. Ex. 1.0000.05.416835-6/001, Rel. Des. Sérgio Braga, j. em 05/04/05 - TJRS,

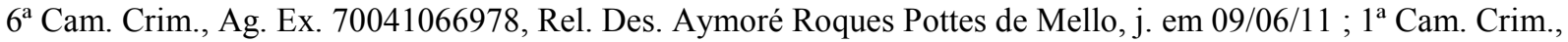
Ag. Ex. 70040830119, Des. Rel. Marco Antônio Ribeiro de Oliveira, j. em 06/04/11.
} 
A falta de aparelhamento dos órgãos da execução da pena, o desinteresse mesmo em saber o que o preso faz ou deixa de fazer, enfim, a omissão do Estado que deixa o preso abandonado na cela, são os motivos pelos quais o seu trabalho artesanal não foi considerado para efeito de remição. E o mais preocupante é o fato de que este preso, enquanto trabalhava artesanalmente e limpava a sua cela, via outros fabricando facas, armas de fogo caseiras, extorquindo outros presos, traficando ou usando entorpecentes no estabelecimento penal.

Longe de se estar defendendo, contra tudo o que já foi dito, seja o trabalho deste preso, que labora artesanalmente, ressocializador ou não, porque a questão é outra. Nenhum trabalho em condições de encarceramento pode ser ressocializador, se é que o trabalho em meio livre, como já abordado, tem ainda algo de socializador. Trata-se de questão de justiça e de respeito à dignidade da pessoa humana ${ }^{143}$, a consideração por parte do Poder Judiciário para com o seu trabalho artesanal, realizado em condições físicas e psicológicas deficientes.

A propósito, se há trabalho no meio livre que possa fazer o homem sentir valor por sua criação, que deixe o trabalhador orgulhoso pelo resultado da tarefa executada, este trabalho é o artesanal. Por certo é um dos que tem as piores remunerações, tendo em vista ser obra excluída da padronização comercial imposta pelo sistema econômico, mas não cabe ao Judiciário desmerecê-lo, uma vez que é atividade lícita e exercida dentro do vácuo de legalidade criado pelo próprio poder público. Lembre-se mais, que todo produto comercial é originado de um projeto fabricado de acordo com uma matriz artesanal

O mais curioso é que a desconsideração da atividade artesanal vai de encontro com o próprio incentivo que o Ministério da Justiça tem promovido no interior dos estabelecimentos penais brasileiros. Como referido anteriormente (3.4.1), tem sido comum observarmos os presos costurando bolas ou redes de futebol ou vôlei, atividades que fazem parte do projeto do governo federal denominado Pintando a Liberdade ${ }^{144}$. Ora, o que é a atividade de costurar uma

\footnotetext{
${ }^{143}$ Para uma visão que liga o trabalho ao próprio processo vital do ser humano, vide Hanna Arendt, para quem "não resta dúvida de que, como o processo natural da vida reside no corpo, nenhuma atividade é tão imediatamente vinculada á vida quanto o trabalho" (2010, p. 136).

${ }^{144}$ Conhecemos pessoalmente tal projeto quando foi aplicado no Estado do Amazonas, mas é empreendimento de nível nacional. Em São Paulo foi inaugurado em junho de 2004, na Penitenciária Nilton Silva, em Franco da Rocha, e segundo números da Secretaria de Esporte, Lazer e Juventude, já foram produzidas 68.000 bolas e 1.801 redes no Estado (Disponível em: <www.selt.sp.gov/pintando_liberdade.php>. Acesso em 9 jul 2011).
} 
bola ou uma rede, se não ? O que não é possível é o judiciário escolher a atividade artesanal que pode e a que não pode servir para a remição.

Observe-se que a LEP permite expressamente o trabalho artesanal, apenas deixando expresso que "deverá ser limitado, tanto quanto possível, o artesanato sem expressão econômica, salvo nas regiões de turismo" (art. 32, § $1^{\circ}$ ). A limitação, diante das condições do sistema penitenciário, com a ausência quase absoluta de qualquer outra atividade, para usar o termo da lei, não é possivel.

O mesmo se diga do trabalho de limpeza, que a decisão em comento afastou por não ter papel ressocializador. Quando a LEP diz que "poderá ser atribuído horário especial de trabalho aos presos designados para os serviços de conservação e manutenção do estabelecimento penal" (art. 33, parágrafo único), está mais do que autorizando este tipo de atividade e a está reconhecendo como trabalho; assim, deve ser tratada como tal, para todos os fins, sem motivos para se excluir a remição.

Por fim, importa ainda fazer algumas considerações sobre a remição pelo estudo. A atual redação do art. 126 da LEP diz que o preso terá direito à remição, à razão de um dia de pena a cada doze horas de estudo $\left(\S 1^{\circ}, I\right)$. Isto quer dizer que o legislador equiparou quatro horas de estudo a um dia de trabalho, porque se três dias de trabalho levam a um dia de remição, divide-se doze horas em três e se terá o equivalente a um dia de trabalho. Por isso o legislador limitou o tempo de estudo para efeito de remição ${ }^{145}$, estabelecendo que as doze horas devem ser alcançadas no prazo mínimo de três dias, ou seja, o preso não pode estudar mais de doze horas neste três dias para efeito de remir mais tempo de pena.

Diante da norma em questão, o preso que estudar mais de doze horas em três dias não poderá remir mais de um dia da pena. Todavia, é bom que se diga, porque defendemos a remição quando não é dado o direito para que o preso trabalhe, que tal limite de remição só pode existir se sempre for dada a oportunidade para o preso estudar. Se não for oferecido ao preso nem trabalho nem estudo em determinado dia, poderão ser contadas, para fins de remição, as horas que esse preso estudou a mais naqueles três dias.

${ }^{145}$ Art. 196, § $1^{\circ}$, I: "1 (um) dia de pena a cada 12 (doze) horas de frequência escolar - atividade de ensino fundamental, médio, inclusive profissionalizante, ou superior, ou ainda de qualificação profissional - divididas, no mínimo, em 3 (três) dias". 
Acertadamente, a norma do $\S 3^{\circ}$ do art. 126, autorizou a cumulação do tempo de trabalho com o tempo de estudo, portanto se, por culpa da administração, ao preso não for possível trabalhar nem estudar para integralizar o tempo de três dias que precisa para a remição, terá direito à remição, conforme defendemos no tópico anterior. Tanto o trabalho quanto o ensino (art. 41, II, da LEP) são direitos garantidos por lei ao preso. Assim, não importa qual dessas atividades está sendo negada, uma vez que ambas lhe dariam direito à remição; esta deve ser concedida, comprovada a omissão do Estado. A remição é direito ligado diretamente à liberdade, inadmissível, pois, qualquer subterfúgio interpretativo para negá-la ou retardá-la.

\subsection{PENA PRIVATIVA DE LIBERDADE E PROGRESSIVIDADE}

A progressão de regime, como o trabalho penitenciário, é outro mecanismo estreitamente relacionado ao plano ressocializador. Assim, antes de falar sobre a progressividade da pena, cumpre-nos retroceder no tempo e avaliar novamente certas circunstâncias, para que fique esclarecida a natureza do instituto, a fim de afastar qualquer ideia de benefício que prejudica sobremaneira o respeito aos direitos e garantias da pessoa presa.

Por fazer parte da pena privativa de liberdade, a progressividade, independentemente do ideal que lhe deu origem, pode e deve ser vista como direito equivalente ao direito à liberdade de qualquer um. Se a lei cria a possibilidade de a pena privativa de liberdade ser cumprida de forma menos rigorosa, esta lei não pode ser interpretada excluindo-se considerações evidentes da realidade punitiva e carcerária.

\subsubsection{Progressão de regime e defesa social}

Marc Ancel, como vimos, expoente da Escola da Nova Defesa Social, confirma que todo o movimento penitenciário que surgiu após John Howard, até as experiências dos cárceres norte-americanos na Pensilvânia, pode ser considerado início da prática que levou ao surgimento do núcleo da defesa social, a ressocialização. Dito pelo próprio Ancel, "não seria difícil demonstrar que se pode encontrar nesse movimento, quando não as doutrinas, pelo menos amplamente o espírito da defesa social" (1979, p. 47). 
Não é por acaso que a nova defesa social tenha se diluído em várias propostas e em variados sistemas, dificultando mesmo a sua afirmação como uma teoria científica. $\mathrm{O}$ intento de se humanizar a pena de prisão é conflituoso por si só, seja porque o conceito do que é humano é diferente em cada um, seja porque a própria ressocialização é um termo preenchido pelos mais diversos valores. Afinal, “o que Ancel não responde é até onde pode chegar a ação reeducativa ou ressocializadora. A estas perguntas, a nova defesa social pretende responder com um 'humanismo' que não explica em que consiste” (ZAFFARONI; PIERANGELI, 1997, p. 324).

Nesse passo, evidentemente não haveria como surgir um sistema de cumprimento de pena aceito por todos, não sendo de se estranhar igualmente que não haja um sistema progressivo igual ao outro (MUAKAD, 1996), sendo cada país e cada doutrinador responsável por sua própria construção.

Falaremos do sistema progressivo de cumprimento da pena privativa de liberdade no Brasil logo adiante (3.5.2 e 3.5.4). O que queremos enfatizar no momento é a relação do sistema progressivo com o ideal de ressocialização.

Bem se vê que toda intenção de fazer da execução da pena de prisão algo paulatinamente menos rigoroso, ou mais rigoroso, de acordo com o comportamento, nasceu do desejo de se recuperar o criminoso, do interesse de ensinar o certo e o errado de acordo com a conduta do preso.

Na tese de Gramatica, o precursor da nova defesa social, mesmo tencionando substituir a nomenclatura de pena por medida de defesa social e a de crime por conduta antissocial, não podia deixar de existir semelhante estrutura. O tratamento planejado então era uma espécie de sistema de defesa social que tinha como características o fato de as medidas de defesa social poderem ser substituídas umas pelas outras de acordo com a necessidade. Tal tratamento e suas medidas devem “ter caráter indeterminado, já que hão de ser continuamente modificáveis, substituíveis, elimináveis, no curso da execução e em relação com o constante controle da personalidade"146 (GRAMATICA, 1974, p. 286). Note-se que, apesar de mais uma mudança

${ }^{146}$ No original: "tener caráter indeterminado, ya que han de ser continuamente modificables, substituibles, eliminables, em el curso de la ejecución e en relación con el constante control de la personalidad" (GRAMATICA, 1974, p. 286) 
de nomenclatura, entre as medidas de Gramatica havia a reclusão que deveria se diferenciar da prisão somente pela função reeducadora e pedagógica que traria.

Marc Ancel, pelo menos em sua obra principal, não desenvolveu nenhum sistema específico para a execução da pena privativa de liberdade, pois preferiu relacionar uma gama de sistemas, em uma espécie de direito comparado, e indicar as medidas que ele entendia como de defesa social. E entre essas estavam relacionadas as medidas por tempo indeterminado, principalmente no que se refere à medida de segurança, aceitando certas classificações, e "mesmo em relação aos criminosos habituais que outrora se presumia incorrigíveis, testar meios de reeducação, tentar aplicar-lhes um regime progressivo, um livramento condicional, e enfim um verdadeiro método de tratamento" (1979, p. 345).

Ocorre que todas essas medidas e a crença no ideal do tratamento, mesmo antes do reforço da nova defesa social, ocasionaram um efeito que normalmente é esquecido por todos. $\mathrm{O}$ efeito de aumento do tempo da pena de prisão. De fato, se a pena funcionaria como local e momento de tratamento, seria necessário tempo para esse tratamento e daí uma ótima justificativa para se aumentar o tempo de pena ${ }^{147}$.

Não é à toa que a maior parte do movimento de defesa social tenha sido contrária às penas de curta duração. Seriam penas de caráter eminentemente retributivo e, portanto, desnecessárias. Para tanto, desde Adolph Prins já se defendia a adoção do sursis, ou ainda na Escola Positiva, com Enrico Ferri, a aplicação dos "substitutos penais" (SILVA, 1991 p. 33).

Como as penas curtas não serviam para a ressocialização do condenado, aplicava-se lhe o sursis ou qualquer outra medida. E o sursis é um instituto revelador, pois, tendo sido adotado pela Escola da Nova Defesa Social como um instrumento útil para se evitar as penas de curta duração, e ainda como medida ressocializadora ${ }^{148}$, terminou se transformando nos dias de hoje em uma medida penal alternativa ao encarceramento e em um direito do réu que

\footnotetext{
${ }^{147}$ Angela Davis, citando Lucia Zedner, explica que foi nítido esse fenômeno no encarceramento feminino dos EUA: "sentencing practices for women within the reformatory system often required women of all racial backgrounds to do more time than men for similar offenses. 'This differential was justified on the basis that women were sent to reformatories not to be punished in proportion to the seriousness of their offense but to be reformed and retrained, a process that, it was argued, required time" (2003, p. 72)

${ }^{148}$ Em Aníbal Bruno, no sursis a pena é substituída por uma atitude que estimule o delinquente a coordenar, dentro da liberdade, as normas da sua vida pelas normas do Direito, não voltando, assim, a delinquir (1984, p. 170)
} 
preenche os requisitos para obter tal suspensão da pena. Diz-se revelador, porque a progressão de regime, que também nasceu como instrumento de ressocialização, deveria igualmente ser considerada um direito do preso e não mais um mecanismo da técnica ressocializadora.

Aliás, o sursis, mesmo considerado como medida descarcerizadora, carrega grande força legitimadora da própria prisão:

Na verdade, o sursis reinventa a ameaça penal no processo de execução e relegitima
a pena curta a partir da desobediência do condenado; sua inaptidão para questionar
essencialmente a pena privativa de liberdade explica a 'moda' (a expressão foi usada
por Ferri) do sursis na Europa na virada do século (...) A introdução do sursis no
Brasil, em 1924, se dá muito mais por efeito da mímesis jurídica que parece ser um
legado do colonialismo do que como decorrência de consciente comprovação dos
malefícios acarretados pela execução das penas curtas (BATISTA, 1990, p. 124-
126).

O livramento condicional da mesma forma. Para os idealizadores da pena tratamento, era item que acompanhava e se incluía no rol de medidas ressocializadoras, mas hoje deve ser visto como medida alternativa que vem para diminuir o tempo de encarceramento e reduzir os males da prisão ${ }^{149}$. Igualmente um direito do condenado que preenche os requisitos necessários para obter tal medida.

Devemos, primeiro, ter em mente que a ideia da ressocialização possibilitou a cultura de aumento das penas em prol do tratamento. Vimos esse tipo de justificativa nas decisões sobre a individualização da pena na sentença, mas tal conduta fez e faz parte principalmente da atividade legislativa. Da mesma forma que há juiz que agrava pena com a pseudo justificativa de que assim o faz para ressocializar, os legisladores tenderam ao aumento do tempo das sanções durante o período histórico em que o ideal de ressocialização esteve presente.

Na exposição de motivos do atual Código Penal brasileiro que, não obstante a reforma da parte geral de 1984, ao menos no que se refere ao mínimo e máximo das penas, é de 1940 e seguiu uma espécie de conciliação entre a Escola Clássica e a Escola Positivista, o legislador expressamente adotou "um sistema penitenciário (sistema progressivo) que é incompatível com as penas de curta duração" (Exposição de Motivos do CP de 1940, Item n. 31, in

${ }^{149}$ De acordo com a exposição de motivos da nova parte geral do Código Penal, o livramento condicional se insere em um "novo sentido à execução das penas privativas de liberdade. A ineficácia dos métodos atuais de confinamento absoluto e prolongado, fartamente demonstrada pela experiência, conduziu o Projeto à ampliação do arbitrium iudicis, no tocante à concessão do livramento condicional” (Item n. 72) 
PIERANGELI, 2001, p. 420). E o aumento de penas é evidente quando se compara o primeiro Código Penal da República, de 1890 , com o atual ${ }^{150}$. O delito de moeda falsa, por exemplo, teve a pena aumentada de um a quatro anos (art. 239), para três a doze anos (art. 289); o furto, que tinha os limites da sanção entre dois meses a três anos (art. 330, $\S \S 1^{\circ}$ e $2^{\circ}$ ) passou para um a quatro anos (art. 155); o roubo, de dois a oito anos (art. 356), passou para quatro a dez anos (art. 157).

O próprio Código de 1890 já trazia medidas tidas como de tratamento na época, tentando conciliar o modelo irlandês com o de Alburn, com elementos "que se destinavam a promover a inserção do criminoso na sociedade, numa escala que ia do confinamento mais rígido para o seu abrandamento e obtenção da liberdade" (SALLA, 1999, p. 133). Isto quer dizer, então, que a legislação brasileira sempre teve o ideal de tratamento presente a influenciar o aumento de penas. A pena tratamento, que não compactua com sanções curtas, sempre existiu na mente de legislador.

Ressalte-se que a redação original do Código Penal de 1940 foi ao extremo de estabelecer penas por tempo indeterminado, uma vez que a medida de segurança era aplicável ao condenado presumido como periculoso, entre eles o reincidente, o condenado a pena de reclusão de mais de cinco anos e aquele em que o crime fosse relacionado à ociosidade, vadiagem ou prostituição (art. 93). No denominado duplo binário, os considerados pelos juízes periculosos, eram submetidos à medida de segurança por tempo indeterminado após o cumprimento da pena (CAMARGO, 2002-b).

Embora o Código de 40 tenha sido elaborado sob influência do fascista Código Rocco italiano, portanto antes do início do movimento de Gramatica e Ancel na mesma década, foram justamente as regras relacionadas às medidas de segurança e a "preocupação com uma reforma penitenciária voltada para a ressocialização futura do detento" (ANCEL, 1979, p. 197), oriundas da influência positivista, que acabaram identificadas como medidas de defesa social pelo novo movimento do mesmo nome.

\footnotetext{
${ }^{150}$ Em 1932 houve a Consolidação das Leis Penais, que já trazia medidas como o livramento condicional, o qual podia ser concedido com o cumprimento de metade da pena se houvesse indicativo de regeneração, (art. 50), legislação na qual já se percebe o aumento considerável do tempo de sanção.
} 
Bem, o nosso objetivo é deixar claro que a pena sempre aumentou para se adotar o sistema progressivo de cumprimento da pena privativa de liberdade. E fazemos isso porque não raro há comentários de que o regime semiaberto ou o regime aberto são benefícios ou mesmo impunidade. Ora, se tais regimes menos rigorosos nasceram sob o ideal da ressocialização, podemos dizer que a parcela da pena onde se cumpriu a retribuição pelo mal causado está no regime mais rigoroso.

O princípio da legalidade, aliás, já deveria ser suficiente para que se afastasse a ideia de benefício. Mas dizer que a progressão de regime é direito do apenado não deriva somente do fato de que a pena, ou seja, a restrição de liberdade de um membro da sociedade, só pode ser imposta com base na lei.

Iniciado o período clássico do direito penal, tradicionalmente a tendência do legislador sempre foi a de limitar a atividade do julgador, principalmente no ato de aplicação da pena, impondo limites às sanções, estabelecendo pena mínima, parâmetros dos quais o magistrado não poderia se afastar. O que demonstra que o legislador não abdica de certa quantidade de punição que acha imprescindível. Dizendo de outra forma, o legislador tem um "amplo poder para decidir sobre o castigo" (CHRISTIE, 2004, p. 84), e não abre mão facilmente do exercício de tal poder.

Ora, assim é a progressão de regime. Quando o legislador estabelece um período mínimo para a progressão, na verdade, este é o período máximo que o preso deve ficar sob aquela forma mais grave de restrição à liberdade. A discricionariedade que o legislador tem sobre o castigo indica que as fases mais rigorosas da pena são tidas, por opção do próprio legislador, como um castigo suficiente. A pena, além daquele período, foi considerada pelo legislador possível de se cumprir de forma mais próxima ao meio social, ou seja, com menos restrição à liberdade, portanto mais favorável ao preso e, por isso, é um direito. Não é um favor, mas um direito estritamente ligado ao direito fundamental do ser humano à liberdade.

Embora a reforma da parte geral do atual Código Penal, em 1984 (Lei 7.209), não tenha causado alterações nos limites das penas, o sistema progressivo, como o sursis e o livramento condicional, mudou de natureza: "A fim de humanizar a pena privativa de 
liberdade, adota o Projeto o sistema progressivo de cumprimento da pena" (Exposição de Motivos, Item n. 35).

Difícil entender o fim humanizador dentro da pena de prisão, objetivo do legislador de 84 e dos precursores da nova defesa social. Mais parece uma transigência com a insensatez, mas é necessário se colocar no lugar do legislador, frente à pressão por sanções cada vez mais severas e, mesmo sabedor da inutilidade da prisão, ter de elaborar um código penal que satisfaça os anseios sociais e seja ao mesmo tempo minimamente coerente com a realidade.

Se é certo que há na reforma da parte geral do Código Penal e na Lei de Execuções Penais uma forte crença no ideal ressocializador, presente na manutenção e criação de inúmeras medidas projetadas ou reforçadas pela defesa social, nas palavras do legislador o sistema progressivo passou a ser uma forma de amenizar a desumanidade da pena privativa de liberdade. Portanto, mais uma vez, encontramos a ressocialização vindo como subterfúgio para a humanização da prisão. Artifício que, antes de ser humanizador, tem sido legitimador.

Afastada mais uma vez a consideração da ressocialização como termo empiricamente comprovado, excluída qualquer hegemonia científica, passível de ser incluído na estrita legalidade que exige o Estado Democrático de Direito, passemos ao exame do sistema progressivo da pena privativa de liberdade, conforme dispõe o Código Penal e a Lei de Execução Penal.

Já falamos sobre o estabelecimento do regime inicial na sentença, mas cumpre lembrar que o Código Penal, no art. 33, estabelece que "a pena de reclusão deve ser cumprida em regime fechado, semiaberto ou aberto. A de detenção, em regime semiaberto, ou aberto, salvo necessidade de transferência a regime fechado" (caput), penas que serão cumpridas na forma progressiva, "ressalvadas as hipóteses de transferência a regime mais rigoroso" $\left(\S 2^{\circ}\right)$.

Conquanto não haja qualquer diferença prática entre a pena de detenção e a de reclusão, a pena de detenção nunca poderá começar a ser cumprida em regime fechado. Por mais que o réu seja condenado a pena superior a 8 anos (art. $33, \S 2^{\circ}, a$, do CP), em virtude de eventual concurso de crimes que levem à soma de distintas penas de detenção, o regime inicial nunca poderá ser o fechado. No caso, somente poderá ser fixado o regime fechado se aplicada ao menos uma pena de reclusão. 
A ressalva que faz o art. 33, referente á pena de detenção, sobre a possibilidade de esta vir a ser cumprida em regime fechado, diz respeito à regressão de regime, que vem disciplinada na Lei de Execução Penal. Sem esforço se percebe a sintonia entre a comissão que elaborou o projeto de reforma da parte geral do Código Penal e a comissão que elaborou a Lei de Execução Penal. Traçadas as diretrizes do cumprimento da pena privativa de liberdade, ficou a LEP encarregada de disciplinar o mecanismo que movimentaria o sistema de progressão e regressão.

Os requisitos para passagem de regime estão no art. 112 da LEP e são o cumprimento de um sexto da pena no regime anterior ${ }^{151} \mathrm{e}$ o bom comportamento carcerário, este que deve ser verificado pela presença de certidão do diretor do estabelecimento penal. Mais na frente falaremos melhor dos requisitos da progressão de regime tidos como subjetivos (3.6.4), cumprindo-nos agora analisá-los somente sob o aspecto objetivo.

\subsubsection{O regime integralmente fechado e o STF}

O posicionamento do Supremo Tribunal Federal sobre a progressão de regime durante a vigência da norma que determinava serem as penas relativas aos crimes hediondos e assemelhados cumpridas integralmente em regime fechado (art. $2^{\circ}$ da Lei 8.072/90) demonstra o quão vago e ambíguo é o campo da execução penal, onde sentimentos de humanidade podem dar lugar a pensamentos retributivos, onde ressocialização pode conviver com repressão, dando espaço para as mais variadas paixões, prejudicando a coerência do ordenamento jurídico e, principalmente, a certeza inerente à legalidade da pena.

Inicialmente, mister frisar que a pena integralmente em regime fechado, da redação original da Lei 8.072/90, era uma pena mais grave e, portanto, diferente da pena que se cumpria em regime progressivo, por isso que nunca poderiam ambas as sanções terem sido cumpridas no mesmo estabelecimento penal. É princípio básico de isonomia que pessoas sob o mesmo teto não podem ter tratamento diferenciado. Não obstante, o que se viu foi que presos

\footnotetext{
${ }^{151}$ No caso de crimes hediondos a Lei 8.072/90 traz regra diferente, determinando o cumprimento de $2 / 5$ da pena para o primário e de $3 / 5$ para o reincidente.
} 
eram obrigados a permanecer em regime fechado durante toda a pena convivendo com outros que tinham direito à progressão, em um total desequilíbrio do sistema penitenciário.

Esse princípio de isonomia, denunciado por Foucault (1998), referido anteriormente, está na Constituição Federal, no art. $5^{\circ}$, XLVIII, ao determinar que "a pena será cumprida em estabelecimentos distintos, de acordo com a natureza do delito", o qual deve ser tido como corolário direto do princípio de que todos são iguais perante a lei (art. $5^{\circ}$, caput, da CF), pois para que não haja distinção de qualquer natureza a nível de atividade punitiva, é imprescindível que presos de penas diferentes, ou seja, com direitos e deveres diferentes, não cumpram pena no mesmo local.

Não foi por acaso que o legislador determinou que cada regime se cumprisse em estabelecimentos penais distintos, fechado em penitenciária, semiaberto em colônia agrícola e aberto em casa do albergado, para que não houvesse tratamentos dissonantes, com presos com certos direitos diferentes dos outros no mesmo ambiente. Tal situação só causa desconforto, desentendimentos e mesmo revolta entre a população carcerária. Um preso não pode estar na mesma cela que outro, quando as penas de cada um proporcionam formas de execução diversas.

Esta é uma circunstância que nunca foi levada em consideração nas análises de inconstitucionalidade do regime integralmente fechado. Seria necessário mesmo que tal regime, se válido, tivesse o seu próprio estabelecimento penal, como, aliás, a própria Lei de Crimes Hediondos sugeriu no seu art. $3^{\circ}$, quando determina que a União deverá manter estabelecimentos penais de segurança máxima para os presos considerados de alta periculosidade. Inobstante a impropriedade técnica do termo, o que é de somenos importância em uma lei resultado do desvario completo de legislador, ressuscitando uma periculosidade lombrosiana há muito esquecida, só nesses estabelecimentos deveriam ser cumpridas as penas integralmente em regime fechado.

Mas voltando ao posicionamento do STF, entre os julgados que marcaram a posicionamento do referido tribunal estão o $\mathrm{HC} \mathrm{n}^{0}$ 69657-1/SP, julgado em 18 de dezembro de 1992, e o $\mathrm{HC} \mathrm{n}^{\circ} 82.959-7$, julgado em 23 de fevereiro de 2006. No primeiro, a pena a ser 
cumprida em regime integralmente fechado foi considerada constitucional e no segundo, após uma nova composição dos membros da corte, a mesma pena foi tida como inconstitucional.

Advirta-se: não se está aqui querendo afirmar que a mudança de julgamento do STF queira significar qualquer incoerência. A mudança de posição faz parte de um processo democrático e a evolução jurisprudencial está sujeita à alteração de perspectivas políticas, inclusive históricas, de cada um de seus membros. O que se quer ressaltar é a diversidade de fundamentos a favor e contrários, muitas vezes contraditórios, passíveis de influenciar uma decisão referente à execução da pena.

Na primeira decisão, que teve como relator para o acórdão o ministro Francisco Rezek, o STF rechaçou os mesmos argumentos que pouco mais de oito anos depois foram considerados suficientes para entender que havia inconstitucionalidade na determinação do cumprimento da pena integralmente em regime fechado. O voto do Ministro Marco Aurélio, no primeiro julgamento, repetido no segundo, é bastante esclarecedor sobre a atual função da progressão de regime:

Digo que a principal razão de ser da progressividade no cumprimento da pena não é em si a minimização desta, ou do benefício indevido, porque contrário ao que inicialmente sentenciado, daquele que acabou perdendo o bem maior que é a liberdade. Está, isso sim, no interesse da preservação do ambiente social, da sociedade, que dia-menos-dia rebeberá de volta aquele que inobservou a norma penal e, com isto, deu margem à movimentação do aparelho punitivo do Estado. A ela não interessa o retorno de um cidadão, que enclausurou, embrutecido, muito embora o tenha mandado para detrás das grades com o fito, dentre outros, de recuperá-lo, objetivando uma vida comum em seu próprio meio, o que o tempo vem demonstrando, a mais não poder, ser uma quase utopia (fls. 417 do $\mathrm{HC}$ n $^{\circ} 69657$ 1/SP, e fls. 515 do $\mathrm{HC} \mathrm{n}^{\circ} 82.959-7$ ).

Mas não foram só esses os argumentos. A humanização da pena que traz o sistema progressivo, proporcionando esperança para o preso e, portanto, dignidade humana para a execução, também foi fundamento do voto histórico acima referido. A individualização da pena na execução penal, princípio ao qual já nos referimos, também foi usada como argumento, visto que o regime integralmente fechado faria com que todos cumprissem a pena de forma igual, independentemente das características de cada um. Contudo, o voto vencedor entendeu que a individualização da pena estava satisfeita na sentença, quando o juiz aplicava a pena e, na execução, com a possibilidade de livramento condicional. 
Por certo a individualização da pena na execução é baseada no critério reeducativo, e ainda que a opção do legislador pela fórmula harmônica integração social tenha sido para fugir da concepção de uma ressocialização imposta (REALE JR, 1985), não se pode esconder o fato de que ao preso não cabe outra alternativa a não ser se adequar às normas do sistema, visto que é a sua liberdade e a de mais ninguém que está em jogo. Não há como conceber um sistema de prêmios e punições para uma pessoa presa que não seja imposto, visto que diante da privação de liberdade não há outra opção.

Assim foi concebido o sistema progressivo, para adequar a pena ao comportamento do condenado. Colocando de lado a incoerência que é tal proposição, pois o comportamento do encarcerado, todos sabem, quando favorável é porque é adaptado ao cárcere e não ao convívio social, não há como fugir do fato de que o sistema assim foi construído. Para humanizar, para individualizar, ou para ressocializar, o sistema progressivo está previsto no ordenamento jurídico, que deve ser considerado como um todo, inclusive deve ser levado em consideração o fato de que o quantum de cada pena é estipulado dentro desse ordenamento.

Note-se o que demonstramos sobre o aumento de pena no período em que o ideal de ressocialização combatia as penas de curta duração, favorecendo o aumento das sanções. Ora, adotar o regime integralmente fechado, abandonando qualquer medida descarcerizadora ou ressocializadora, para sanções que tiveram o tempo aumentado com base na progressividade é aceitar um acréscimo absolutamente desproporcional. E aqui cabe muito bem o princípio da dignidade humana.

Mesmo que não concordemos com a função ressocializadora da medida, porque inviável no meio em que se pretende, a progressividade existe, o sistema foi criado com pesos e contrapesos utilizando-se dela, portanto ela deve ser considerada como direito do preso, direito inalienável porque incluído no sistema da pena privativa de liberdade na qual foi condenado. Para excluir a progressão de regime do sistema seria imprescindível a reconstrução completa de todo o ordenamento jurídico, principalmente dos limites das penas.

No voto do ministro Carlos Velloso, após este afirmar ter meditado sobre o assunto, assevera que "a denominada lei dos crimes hediondos, no ponto, prestou desserviço ao Direito Penitenciário, porque ela retira a esperança dos presos, dos sentenciados, e um preso sem 
esperança acaba se revoltando" (fls. 429), mas mesmo assim, o ministro não via inconstitucionalidade na lei. De seu turno, para o ministro Néri da Silveira, o Estado combate "a criminalidade, se arma, por via da lei, da cominação, mas, para o combate efetivo a esse tipo de criminalidade, o faz, não só estabelecendo uma pena mais grave, como estipulando, por igual, que o cumprimento da pena se dará segundo regime mais severo" (fls. 440).

Ou seja, o argumento técnico convivendo com o argumento repressivo, mas ambos esquecendo a realidade do sistema penitenciário. Estes dois votos são exemplos da difículdade de se avaliar os direitos dos presos de forma clara e taxativa em uma pena verdadeiramente respeitadora da estrita legalidade. Neste primeiro julgamento não se cogitou em definir o princípio da individualização da pena na execução e contentaram-se em tê-lo como inexistente, esquecendo que o ordenamento foi forjado com base nele e que não se pode criar pena aleatoriamente, sem procedimento executório específico.

Simplesmente a Lei de Crimes Hediondos não só vedou a esperança, a pequena chama que mantém muitos presos sãos. Não só esqueceu que o retorno do preso abruptamente, saindo direto do regime fechado para a liberdade, só seria pior para a própria sociedade, porque além de embrutecido, o preso retornaria revoltado. Não esqueceu também somente o fato de que as sanções são elevadas porque há o sistema progressivo. A Lei de Crimes Hediondos esqueceu tudo para criar uma pena nova, sem nexo, sem coerência, desumana.

Bastava uma interpretação por exclusão da Constituição Federal para se concluir pela inconstitucionalidade do regime integralmente fechado. Pois, se a carta magna veda no art. $5^{\circ}$, XLVII, penas de morte, de caráter perpétuo, de trabalhos forçados, de banimento e cruéis, e a ciência hermenêutica diz que a lei não usa dois termos para significar a mesma coisa, porque não usa palavras supérfluas, resta saber o que são as penas cruéis proibidas constitucionalmente.

Ora, se a pena cruel não é a pena de morte, nem a de caráter perpétuo e nenhuma outra dessas já relacionadas no inciso XLVII do art. $5^{\circ}$ da Constituição, então o que poderia ser essa pena cruel, se não qualquer uma que negue o caráter de esperança ao ser humano preso.

Abdicamos, neste trabalho de adotar uma postura abolicionista, porque, como explicado na introdução, há pessoas presas. Caso contrário, não careceria de muito esforço 
para concluir objetivamente que a pena cruel vedada constitucionalmente, é a própria pena de prisão. Contudo, a nossa voz fala muito mais baixo do que a de muitos que já denunciaram a crueldade da prisão, mas, mesmo assim, pessoas continuam presas. Por isso é necessário achar uma pena de prisão o mais humana possível e esta só pode existir se deixar alguma luz de esperança no cidadão preso.

Que chamem isso de fim ressocializador da pena, não importa, contanto que traga alguma expectativa de melhorar a condição de vida do preso. Porque qualquer coisa que dinamize a vida em quatro paredes, que permita a possibilidade de sonhar, que altere de forma saudável o dia a dia seco e promíscuo da prisão, enfim, qualquer coisa nesse sentido é favorecer a dignidade da pessoa humana, tenha o nome de ressocialização ou não.

E foi por esse caminho que seguiu o STF, adotando o termo ressocialização como ingrediente da individualização da pena, para em seguida considerar inconstitucional o cumprimento da pena em regime integralmente fechado:

PENA - REGIME DE CUMPRIMENTO - PROGRESSÃO - RAZÃO DE SER. A progressão no regime de cumprimento da pena, nas espécies fechado, semi-aberto e aberto, tem como razão maior a ressocialização do preso que, mais dia ou menos dia, voltará ao convívio social. PENA - CRIMES HEDIONDOS - REGIME DE CUMPRIMENTO - PROGRESSÃO - ÓBICE - ARTIGO $2^{\circ}, \S 1^{\circ}$, DA LEI N ${ }^{\circ}$ 8.072/90 - INCONSTITUCIONALIDADE - EVOLUÇÃO JURISPRUDENCIAL. Conflita com a garantia da individualização da pena - art. $5^{\circ}$, inciso XLVI, da Constituição Federal - a imposição, mediante norma, do cumprimento da pena em regime integralmente fechado. Nova inteligência do princípio da individualização da pena, em evolução jurisprudencial, assentada a inconstitucionalidade do art. $2^{\circ}, \S 1^{\circ}$, da Lei 8.072/90 (STF, HC 82.959-7/SP, Rel. Min. Marco Aurélio, j. 23/02/06).

Assim o STF afastou uma nódoa do ordenamento jurídico. A pena integralmente em regime fechado dissociada de toda a construção legislativa. Ocorre que, ao usar o termo ressocializador, o STF acabou dando mais um reforço de legitimidade para a pena de prisão e para as penas de longa duração. No nosso modesto entender, o STF perdeu a oportunidade de demonstrar só poderem ser feitas reformas penais que atinjam a execução da pena, no bojo de uma reforma ampla.

O STF deixou passar a ocasião de "denunciar os casos em que o Poder Legislativo procura dar, pela via penal, soluções aparentes a conflitos de outra natureza, para os quais deve-se encontrar soluções em âmbitos alheios ao sistema penal” (CERVINI, 1995, p. 112), conduta que tem favorecido a elaboração de leis desconexas e dissociadas do sistema. 
Contudo, do que se depreende das declarações de votos dos ministros, o que se viu foi justamente o contrário, tendo o ministro Celso de Melo, em um dos votos vencidos, desta feita adotando o anterior posicionamento do ministro Néri da Silveira, já aposentado, expressado que a regra legal discutida "resulta da necessidade de o Estado estabelecer mecanismos diferenciados de repressão à criminalidade violenta" (fls. 690, grifo no original).

Leis pontuais assim são, como sempre, vazias de conteúdo, porque embaladas pelo sentimento da opinião pública forjado pela mídia. Pura ação repressiva destituída do pensamento (SÁ, 2007), necessário para a formação de um raciocínio sistêmico. Tal intenção legislativa é típica de um direito penal hermeticamente fechado, que não dialoga com a criminologia e nem procura adequar a da lei aos fatos da vida real:

"Buscar nas proibições penais a solução do problema do crime é uma ingenuidade.
Supor que o Direito Penal deva considerar-se a resposta natural, a primeira e mais
eficaz, em princípio é uma absurda crueldade, própria do despotismo não ilustrado.
Tanto como confundir os primeiros socorros ou o tratamento clínico como cirurgia!
Do ponto de vista de política criminal, o controle racional da delinquencia reclama o
prévio desenvolvimento de uma justa e eficaz política social que incida a tempo nos
fatores que favorecem ou configurem o crime e busque a instauração de uma
sociedade mais sã" (Antônio García-Pablos de Molina apud FRANCO, 1994, p. 57-
58).

No debate em plenário, o que mais temos de semelhante ao que se afirma neste momento foi a declaração do ministro Sepúlveda Pertence quando se referia à impossibilidade de o intérprete avaliar as negociações de câmara, prévias à aprovação de uma lei: "insisto na comparação das leis com as salsichas" (fls. 722), disse o saudoso ministro, trazendo citação de Bismarck. Com efeito, mas o judiciário não precisa saber como foram feitas as salsichas, nem as leis, para evitar comer umas e aplicar as outras, basta verificar seu aspecto externo corrompido.

O STF acabou encontrando uma saída conciliadora. Para satisfazer a opinião pública costuma-se usar o argumento ressocializador e afirmar (informar) que o preso sairá da prisão pior do que entrou. Como ninguém quer isso, apesar de saber disso, é um bom argumento. Mas continuamos com a prisão e com pessoas saindo pior de lá. Ao mesmo tempo, legitima-se a prisão com o sonho de que algo pode ser feito para ressocializar.

Bem, o intuito ressocializador do STF foi por água abaixo, porque logo depois da histórica decisão que considerou inconstitucional a pena sem progressão de regime, o 
legislador colocou para funcionar sua fábrica de leis (salsichas?) e tratou de criar uma nova pena, mais grave, mas que aparentemente satisfaria a necessidade de progressão de regime, cumprindo o princípio da individualização da pena.

Trata-se da Lei 11.464, de 28 de março de 2007, que um ano após a decisão do STF veio estabelecer que a progressão de regime para os crimes considerados hediondos e assemelhados se daria não com um sexto, conforme a previsão da Lei de Execução Penal (art. 112), mas com dois quintos, no caso de primeira condenação, e de três quintos, no caso de reincidente. Isto é, o legislador então criava outra nova pena, agora não mais com vedação à progressão de regime, mas com a obrigação de que o condenado por crime hediondo cumprisse tempo superior até mesmo ao período necessário para livramento condicional do condenado por crime comum (um terço, na forma do art. 83 do $\mathrm{CP}$ ).

Fácil concluir que a elucubração do legislador foi só uma forma de compactuar com a decisão do STF e continuar mantendo uma pena dissociada do sistema. Na nova pena, somente de forma aparente foi mantido o sistema progressivo, porque quando o apenado obtiver o regime semiaberto, após cumprir dois quintos da pena, não chegará ao regime aberto, pois o tempo para o livramento condicional será alcançado primeiro. Se não, vejamos: o período para o livramento condicional por crime hediondo continuou sendo de dois terços (art. 83, V, do $\mathrm{CP}$ ), então, antes de o apenado cumprir novamente dois quintos da pena para seguir para o regime aberto, ele terá direito ao livramento condicional. Portanto, o legislador deixou subsistir o regime progressivo, mas um sistema progressivo capenga, pela metade.

Se não bastasse isso, todos os argumentos que trouxemos até agora não são desfeitos com a saída estratégica do legislador. E isso porque continua havendo uma nova pena no ordenamento jurídico, com um sistema progressivo diferente e, portanto, deveria ser cumprida em estabelecimento penal distinto. Fazer um condenado cumprir a pena de dois quintos na mesma cela do que cumprirá a de um sexto é permitir que duas pessoas sujeitas a regimes jurídicos diferentes convivam sob o mesmo teto, o que, como salientado, não cumpre mandamento constitucional.

O magistral ensinamento de René Dotti de que "os estabelecimentos penais constituem a base material de um dos mais relevantes aspectos do sistema e por isso jamais poderiam ser 
desconsiderados" (1998, p. 352), olhado sob o prisma da regra constitucional de que penas distintas devem ser cumpridas em estabelecimentos penais distintos (art. $5^{\circ}$, XLVIII, da Constituição Federal), leva à consideração de que a nova pena, a pena de dois quintos em regime fechado, está carente de estabelecimento penal e, na prática, impossibilitada de ser executada.

A reconhecida regra de que penas de natureza distintas devem ser cumpridas em estabelecimentos penais diferentes é, com efeito, norma que nasceu no bojo do reformismo ressocializador. As Regras Mínimas das Nações Unidas para o Tratamento dos Reclusos (ONU/ Aprovada 1955, Res. 663C [XXIV] 31.07 .57 e 2076 [LXII] 13.05.77) já estipulavam que "os reclusos pertencentes a categorias diversas deverão ser alojados em diferentes estabelecimentos ou em diferentes seções dentro dos estabelecimentos, segundo sexo e idade, seus antecedentes, os motivos de sua detenção e o tratamento que corresponda aplicar-lhes" (Apud MAIA Neto, 1998, p. 140) ${ }^{152}$.

Contudo, independentemente do abandono da ressocialização como meta, a mistura de presos, o convívio dos que têm de cumprir penas distintas, fere a dignidade desses seres humanos. Fazer, por exemplo, um condenado por tráfico de entorpecentes à pena de 5 anos de reclusão (art. 33 da Lei 11.343/06) que, em tese, só terá direito a ingressar no regime semiaberto com o cumprimento de 2 anos de pena ( $\left(2^{\circ}\right.$ do art. $2^{\circ}$ da Lei 8.072/90), ficar recolhido no mesmo estabelecimento penal que um condenado por homicídio à pena de 6 anos de reclusão (art. 121 do Código Penal) que, em tese, terá direito à progressão para o semiaberto com o cumprimento de um ano da pena (art. 112 da LEP), é algo incompreensível e até agressivo para aquele que já sofre os males do encarceramento, resultando inclusive, como a prática tem demonstrado, em motivo de insatisfações e distúrbio no próprio estabelecimento penal.

Em suma, a pena de dois quintos no regime fechado, na forma como está sendo cumprida, é, para ser ameno, de uma constitucionalidade extremamente duvidosa.

\footnotetext{
${ }^{152}$ As regras mínimas do Preso no Brasil, do Ministério da Justiça, Resolução ${ }^{\circ} 14$ do Conselho Nacional de Política Criminal e Penitenciária, de 14.11.94, trazem, em seu Art. $7^{\circ}$, que "os presos pertencentes a categorias diversas devem ser alojados em diferentes estabelecimentos prisionais ou em suas seções, observadas as características pessoais tais como: sexo, idade, situação judicial e legal, quantidade de pena a que foi condenado, regime de execução, natureza da prisão e o tratamento específico que lhe corresponda, atendendo ao princípio da individualização da pena" (Apud MAIA Neto, 1998, p. 138).
} 
Por fim, fica a lição de que o sistema jurídico já não confia nele mesmo quando percebemos o judiciário, notadamente a mais elevada corte do país, permitir a validade de normas absolutamente desvinculadas do ordenamento jurídico, ordenamento este que deve ter princípios, fundamentos, coerentes entre si. Se a ciência jurídica confiasse no seu sistema, na conexão de suas regras, tais normas não seriam aceitas, porque inviáveis.

Se a imposição de pena em regime integralmente fechado era dissociada do ordenamento jurídico, a nova pena também o é, pois a sistemática penal original não a previu, permanecendo válido, portanto, o ensinamento de Pitombo:

"Falha, em consequência, toda a política criminal, com sério atentado à justiça. As
penas cominadas, tanto que aplicadas e, ulteriormente, postas em execução, precisam
exibir, sempre, certa totalidade ordenada. Devem, também, ostentar coerência em si.
Os preceitos incompatíveis com o sistema de penalidades, por isso, hão de ser
reconhecidos inválidos, mediante interpretação que os rebata, por violadores, assim
desviando a injustiça (1999, p. 155).

Se for para o movimento lei e ordem vencer, que ele crie seu próprio sistema punitivo, porque o que não pode é esse movimento, ficar criando regras mais rigorosas dentro de um sistema que já tem as penas altas em razão da adoção do critério ressocializador. Talvez, se isso acontecesse, voltássemos para o sistema do Código Imperial, sem progressão de regime, mas com penas de um ou dous mezes de prisão.

\subsubsection{Detração}

A Lei de Execução Penal não tratou de forma clara e profunda de um instituto que tem enorme influência na progressão de regime, que é a detração. Norma do Código Penal que determina computar-se "na pena privativa de liberdade e na medida de segurança, o tempo de prisão provisória, no Brasil ou no estrangeiro, o de prisão administrativa e o de internação em qualquer dos estabelecimentos referidos no artigo anterior" (art. 42).

Da redação do artigo citado resulta inequívoca a intenção do legislador em abranger qualquer prisão cautelar, no Brasil ou no estrangeiro e em qualquer estabelecimento penal, portanto, apenas para não haver dúvida, incluem-se entre as prisões que devem ser computadas como cumprimento de pena, a prisão temporária e a prisão em flagrante.

A importância do dispositivo é redobrada quando constatado que a prisão antes da sentença condenatória tem se tornado regra no Brasil. Cadeias, delegacias e até containers 
lotados de presos que, para a Constituição Federal, são presumidamente inocentes (art. $5^{\circ}$, LVII). Muitos desses presos cumprem a pena integralmente na condição de presos provisórios ${ }^{153}$, chegando o processo na vara de execuções somente para arquivamento.

A prisão cautelar tem um grau de sofrimento maior que o da prisão por condenação. Se não bastasse todo o ritual de estigmatização, as celas inapropriadas das delegacias, o batismo de chegada em um centro de detenção provisória, o difícil acesso à defensoria pública, o preso tem ainda poucas informações sobre o andamento do seu processo e não tem a mínima ideia de quando, e se vai ser posto em liberdade. Como em O Processo de Kafka, "esse método era, naturalmente, muito eficaz para entorpecer o acusado e mantê-lo desprotegido, para depois, repentinamente, o surpreender com a sentença" (p. 90).

Não há dúvidas de que, no sentido de sofrimento, a pena embutida na prisão cautelar, é muito mais severa do que a da condenação. Portanto, para que não haja bis in idem, ou seja, para que o condenado não seja punido duas vezes pelo mesmo fato, a lei prevê ser considerado o tempo de prisão cautelar como tempo de cumprimento de pena.

Vemos que a detração compete ao juiz da execução penal, na forma do art. 66, III, $c$, da LEP, devendo o magistrado efetuar o abatimento do tempo de prisão anterior ao trânsito em julgado da sentença condenatória, quando da expedição da guia de recolhimento, documento que instrumentaliza o processo de execução (art. 105 da LEP). Na escassa disciplina que mereceu o instituto, o outro artigo relativo à detração é o art. 111 da LEP que estabelece que "quando houver condenação por mais de um crime, no mesmo processo ou em processos distintos, a determinação do regime de cumprimento será feita pelo resultado da soma ou unificação ${ }^{154}$ das penas, observada, quando for o caso, a detração ou remição".

Repetindo, a determinação do regime será feita observada a detração. Ou seja, se o sentenciado passou mais de um ano preso cautelarmente e foi condenado a nove anos de

${ }^{153}$ Entre inúmeros casos registrados, há o de um cidadão que ficou preso durante 13 anos sem sentença, sem processo e sem inquérito, esquecido completamente passou por rebeliões, punições de isolamento e transferência para presídio de segurança máxima, para ser solto em habeas corpus em 1998, no que foi considerado "o mais grave atentado à violação humana já visto na sociedade brasileira" (LOPES JR, 2009 p. 178).

${ }_{154}$ Por ser equívoco comum, é bom lembrar que soma e unificação diferem. Enquanto a primeira é a simples soma aritmética, o concurso material, de penas, a unificação é a retificação da pena para atender o limite máximo de trinta anos $\left(\S 1^{\circ}\right.$ do art. 74 do $\left.\mathrm{CP}\right)$. A outra hipótese de unificação está prevista no art. 82 , in fine, do CPP, quando o juízo da execução deve examinar a ocorrência de continuidade delitiva que não foi oportunamente verificada em processos de conhecimento que tramitaram separadamente. 
reclusão, o seu regime deverá ser o semiaberto, pois, com a detração, a sua pena passa a ser inferior a oito anos e, seguindo-se a regra do art. 33, $2^{\circ}$, “a”, do Código Penal, o regime só poderá ser o semiaberto.

Ora, uma incongruência: se a detração pode influenciar na determinação do regime de cumprimento da pena, como pode ser o juiz da execução penal o competente para tanto, se a fixação do regime inicial é feita pelo juiz sentenciante? No caso, não há como esperar toda a tramitação do processo até a sua autuação perante o juízo de execução, para que seja feita a detração e corrigido o regime de cumprimento de pena. A solução cabível é o juiz, já na sentença, estabelecer o regime de acordo com o abatimento a que tem direito o réu pela detração. Quando, porém, os processos forem distintos, aí sim, seria o caso de o juiz da execução penal alterar o regime inicial da acordo com a detração.

Ultrapassada essa básica referência à detração, vamos à progressão de regime. Não há dúvida de que sendo considerada a detração cumprimento de pena, o período de um sexto para a progressão de regime deve ser também tido como cumprido, se o sentenciado tiver sido mantido preso cautelarmente por tempo equivalente. Aliás, é conclusão tirada do próprio artigo 111 da LEP, porque se a detração influencia o regime de cumprimento da pena no caso de vários crimes, por mais razão ainda deve influenciar a fixação do regime no caso de apenas um crime.

Por isso, tendo um réu sido condenado no regime fechado e já tendo cumprido mais de um sexto da pena cautelarmente, deve ser imediatamente transferido para o regime semiaberto. Ou seja, a detração deve ser considerada cumprimento de pena também para efeito de progressão. Disso não se duvida e, tanto a doutrina quanto a jurisprudência, são uníssonas nesse sentido, contudo, o problema está quando o réu cumpre provisoriamente além do tempo previsto para o regime fechado, o tempo também previsto para o regime semiaberto, uma excrescência comum da qual falaremos a seguir.

\subsubsection{Progressão por salto}

Vemos aqui outra situação para a qual a doutrina e a jurisprudência também dão um nome pejorativo, negando ao preso direito que deveria ser consequência lógica da detração e do princípio non bis in idem do qual é derivada. Por um distúrbio do sistema jurídico, que 
passou a entender ser a prisão cautelar a regra, o preso permanece durante todo o processo de conhecimento encarcerado e, quando é condenado, já cumpriu quase a totalidade da pena. Mesmo assim, doutrina e jurisprudência entendem não ser possível o cumprimento da sanção no regime aberto, se a condenação foi no fechado, porque isso seria uma progressão por salto.

Nesse caso, mesmo já tendo o preso cumprido um sexto do regime fechado e um sexto do semiaberto, requisitos do art. 112 da LEP, em prisão de natureza cautelar, teria ainda de cumprir mais um sexto no semiaberto para poder pleitear progressão para o regime aberto.

A interpretação para tal posicionamento é, primeiramente, absolutamente literal, dissociada por completo do ordenamento jurídico. Em razão de o art. 112 da LEP estabelecer que a progressão de regime se constitui na "transferência para regime menos rigoroso, a ser determinada pelo juiz, quando o preso tiver cumprido ao menos um sexto da pena no regime anterior", tanto jurisprudência, quanto doutrina, entendem, pelo uso da expressão regime anterior, que a progressão para o regime aberto é inviável, porque o regime anterior é o semiaberto.

É indispensável que ele tenha cumprido, pelo menos, um sexto da pena no 'regime anterior', nos termos do art. 112 da Lei de Execução Penal. Isso quer dizer que o condenado não poderá passar diretamente do fechado para o regime aberto, sem passar obrigatoriamente pelo regime semi-aberto (BITENCOURT, 2009, p. 489) ${ }^{155}$.

Se observarmos que outro dispositivo, já analisado, considera o tempo de prisão cautelar como tempo de cumprimento de pena e, como salientamos, tendo em vista ser esse tempo de prisão cautelar, na verdade, mais aflitivo que qualquer dos regimes de cumprimento de pena, constitutivos do sistema progressivo, não há outra razão para o entendimento de o tempo de detração não valer como tempo de pena em qualquer dos regimes, se não a crença no ideal de ressocialização.

Não pode ser, portanto, o ideal retributivo a origem dessa interpretação, já que o apenado cumpriu a pena de forma até mais grave do que deveria cumprir se o sistema punitivo funcionasse a contento. A não ser que o intérprete, hipótese nada descartável, esteja pensando

\footnotetext{
${ }^{155}$ No mesmo sentido: Rogério Greco (2009); Renato Marcão (2007); Guilherme de Souza Nucci (2008); Alberto Silva Franco, et. al. (1995). No obra de Alberto Silva Franco, entretanto, há a ressalva de que, caso não esteja devidamente estruturado o regime semiaberto, "o condenado não poderá sofrer as contingências da inércia estatal e terá, em princípio, direito de, esgotado o prazo mínimo para o cumprimento da pena em regime fechado, ser transferido para o regime aberto" (p. 405).
} 
que é o condenado mais uma vez quem deve arcar com a ineficiência do sistema, ou que o preso, hipótese menos impossível ainda, por ter sido condenado, deve ser punido com rigor, inviável assim, qualquer interpretação que o favoreça.

Bem, temos duas normas, uma que diz que o tempo de prisão cautelar é tempo de cumprimento de pena (art. 42 do CP) e outra que diz que o preso, para progredir, deve cumprir um sexto da pena no regime anterior (art. 112 da LEP), regras perfeitamente conciliáveis, entretanto, para que uma seja literalmente cumprida, esquece-se a outra.

O intérprete novamente olvida que o legislador não era obrigado a prever o absurdo no qual se tornou a prisão cautelar no Brasil. Não havia como o autor da Lei de Execução Penal criar norma admitindo a irracionalidade de fazer um cidadão cumprir sua pena, totalmente, metade ou um terço dela, antes de ser julgado ${ }^{156}$.

O momento não é para se dissertar sobre a natureza da prisão cautelar, mas é evidente que esta não pode extrapolar os limites do razoável, como vem acontecendo. Basta o princípio da presunção de inocência, dentro de um Estado Democrático de Direito que tem a dignidade de pessoa humana como fundamento, para se extrair daí que a prisão antes do julgamento deve ser exceção e só pode ser usada em último caso. Portanto, não cabe ao legislador, que legisla para um ordenamento jurídico, e dentro dele, prever situação que não se admite na normalidade constitucional.

Diante da existência da prisão cautelar no sistema penal, bastou ao legislador prever a detração, isto é, foi suficiente a lei considerar o tempo de prisão cautelar como tempo de cumprimento da pena, sendo desnecessário a especificação de que esse tempo (de cumprimento de pena) seja considerado neste ou naquele regime.

Vejamos então a jurisprudência, que faz do ideal ressocializador fundamento da progressão de regime, e o principal motivo para negar a progressão ao apenado que cumpriu

\footnotetext{
${ }^{156} \mathrm{Na}$ doutrina de Sérgio Marcos de Moraes Pitombo, um dos autores do anteprojeto que resultou na LEP, há manifestação diferente da maior parte dos demais doutrinadores e que vem em favor do que ora se defende: "O sistema progressivo tem de mostrar execução prática - diga-se: ética e racional. Com efeito: o condenado possuidor de induvidoso direito de avançar, se, porém, não o concretiza, por simples mora na decisão judicial, falta de vaga em estabelecimento ou outro motivo injusto, deve ter computado o tempo de encarceramento indevido. A falha na individualização, na transferência para o regime imediato, há de operar, na execução, de modo virtual. Assim, como se fora a pena atendida, no regime mais brando e para todos os fins. Inaceitável, em qualquer hipótese, a banalização da injustiça" (1999, p. 153).
} 
grande parcela de sua pena em uma de nossas cadeias públicas, ou em qualquer dessas delegacias ou containers:

[...] O cumprimento da pena privativa de liberdade deve ser executado de forma progressiva, conforme os artigos 33, § 2o, do Código Penal e 112 da Lei de Execução Penal, não sendo permitida a transferência do regime fechado para o aberto sem o estágio no regime semi-aberto. Embora o reeducando tenha cumprido 1/6 da pena que lhe foi imposta, a Lei de Execução Penal não permite a progressão do regime fechado diretamente ao aberto, sem ter dado cumprimento no intermediário. $\mathrm{O}$ cumprimento de pena no regime semi-aberto constitui uma fase obrigatória, tendo em vista que o objetivo do instituto da progressão prisional é de reabilitação do sentenciado, de modo a permitir a sua reintegração no convívio social [...] (TJESP 16 Câm. Crim. - Ag. 990.09.107545-0 / Tupã - Rel. Des. Pedro Luiz Aguirre Menin - voto 5.020. v. u. - j. em 15.09.2009) ${ }^{157}$.

Alguns julgadores adotam o objetivo da ressocialização e a crença no sistema punitivo sem dizer de que realidade tiraram tais conclusões. A importância do regime semiaberto está só na lei e não na vida real. Aliás, quando existe colônia agrícola ou industrial onde pode ser cumprido esse regime, o máximo que se encontra é mais um amontoado de presos.

O abandono, na prática, do fim ressocializador, transformou os raros estabelecimentos desse regime em galpões e a própria administração não os vê como local de disciplina ou de reeducação mas, muito pelo contrário, apenas como mais um espaço de recolhimento de presos que aguardam a liberdade. Pior, por ser local com menor vigilância e direitos mais amplos por parte dos presos, muitas vezes as regras do regime semiaberto são tidas como liberalidade.

As decisões jurisprudenciais no mesmo sentido são diversas, restando-nos demonstrar somente que todas partem do princípio de que a progressão por salto não é possível porque o regime semiaberto cumpre uma função ressocializadora. Posicionamento adotado inclusive pelo STJ:

${ }^{157}$ No mesmo sentido, negando progressão por salto: TJSP: HC 0362419-37.2010.8.26.000, $4^{\mathrm{a}}$ Cam. Crim., Rel. Des. Edison Brandão, j. 18/01/11; Ag. Ex. $n^{\circ}$ 990.10.000458-1, $6^{\text {a }}$ Cam. Crim., Rel. Des. José Raul Gavião de Almeida, j. 29/07/10; Ag. Ex. no 990.10.085318-0, 16 ${ }^{a}$ Cam. Crim., Rel. Des. Newton Neves, j. 07/07/10 - TJRS: Ag. $n^{\circ}$ 70014661813, $3^{\text {a }}$ Cam. Crim., Rel. Des. Elba Aparecida Nicolli Bastos, j. 20/04/2006; Ag. ${ }^{\circ}$ 70010122885, $7^{\mathrm{a}}$ Cam. Crim., Rel. Des. Marcelo Bandeira Pereira, j.16/12/2004; Ag. ${ }^{\mathrm{o}} 70015609563,2^{\mathrm{a}}$ Cam. Crim., Rel. Des. Marco Aurélio de Oliveira Canosa, j. 31/08/2006; TJRJ: HC 3435-31.2010.8.19.0000, $7^{\text {a Cam. }}$ Crim., Rel. Des. Siro Darlan de Oliveira, j. 20/07/10; HC 45296-65.2008.8.19.0000, $1^{\text {a }}$ Cam. Crim., Rel. Des. Marcus Basílio, j. 17/09/08; TJMG: Ag. Ex. no 2.0000.00.342199-8, $2^{\text {a }}$ Cam. Crim., Rel. Des. Tibagy Salles, j. 04/09/01; Ag. Ex. $n^{\circ}$ 1.0000.07.454894-2, $1^{\text {a }}$ Cam. Crim., Rel. Des. Márcia Milanez, j. 04/09/07 - TJDFT: HC 20080020134229, Rel. Renato Scussel, $1^{\text {a }}$ T. Crim., j. 23/10/2008; Ag. Ex. n 20060020114660, Rel. Romão C. Oliveira, $2^{\text {a }}$ T. Crim., j. 21/06/2007. 
EXECUÇÃO PENAL. HABEAS CORPUS. DIVERSAS CONDENAÇÕES. ERRO DE UNIFICAÇÃO. INEXISTÊNCIA. (...) 8. Não há falar em progressão per saltum, pois referido instituto, como medida de política de execução criminal, concede ao apenado a oportunidade de, gradualmente, retornar ao convívio social, desde que, como contrapartida, tenha preenchido as condições necessárias que demonstrem a possibilidade de aplicação do benefício. 9. Ordem denegada. (STJ - HC 118.128/SC, Rel. Ministro ARNALDO ESTEVES LIMA, QUINTA TURMA, julgado em 20/10/2009, DJe 16/11/2009) ${ }^{158}$.

A jurisprudência chega a criar uma forma latina: per saltum; como se a negação de progressão fosse resultado de um instituto jurídico consagrado. E aqui encontramos outra circunstância que passa despercebida de toda essa interpretação: tanto a postura eminentemente técnica, dissociada de uma consideração geral do ordenamento jurídico e da realidade, assim como a postura idealista baseada na ressocialização, são atitudes absolutamente incompreensíveis para o encarcerado.

Sim, o encarcerado. Se a norma na execução penal é direcionada para ele e se na norma se pretende um conteúdo de comunicação, seja para ele aprender, seja para se sentir punido, deve-se ter em mente que nem ele nem a massa carcerária entendem possa o judiciário acreditar seja uma regra aplicada de forma mais rigorosa porque vai favorecer a ressocialização. Um comum mortal não pode entender que o tempo de prisão passado em uma cadeia pública seja desconsiderado em nome de um regime semiaberto tão importante quanto abandonado.

Ainda que seja para o condenado se sintir punido de forma mais rigorosa, ele não poderá entender que outros presos, condenados a penas idênticas, possam estar no regime aberto só porque os seus processos tiveram tramitação mais célere. Afinal, os presos condenados a regime fechado que têm condições de iniciar a pena neste regime e vão normalmente para o regime semiaberto são favorecidos três vezes frente àquele que cumpre boa parcela da pena em prisão cautelar.

\footnotetext{
${ }^{158}$ Outras decisões do STJ: HC 165.623/SP, j. em 16/09/10, HC 140.054/SP, j. em 17/11/09 e HC 84.302/SP, j. em 19/03/9, da $5^{\text {a }}$ Turma, Rel. Min. Laurita Vaz; HC 151.268/PR, Rel. Min. Og Fernandes, 6 a Turma, j. em 20/04/2010; HC 81.203/SC, Rel. Min. JANE SILVA, $5^{\text {a }}$ Turma, j. em 14/08/2007; HC 76707-SP, $5^{\text {a }}$ Turma, Rel. Min. Felix Fischer, j . 13/06/2007. Não encontramos decisões recentes no STF sobre o assunto e os julgados trazem como fundamento somente a letra do art. 112 da LEP, para negar a progressão nestes casos: HC 76965, Rel. Min. Sydney Sanches, $1^{\text {a }}$ Turma, j. em 15/12/1998, HC 70646, Rel. Min. Paulo Brossard, 2a Turma, j. em 22/10/1993.
} 
Primeiro porque não passaram tanto tempo aguardando julgamento, segundo porque passaram menos tempo em cadeias piores do que penitenciárias, e terceiro porque tiveram acesso ao regime aberto mais rápido. Em verdade, é o Estado que está em débito com esse condenado que aguarda grande parcela de sua pena preso cautelarmente ${ }^{159}$.

Partindo do pressuposto de que "a reinserção social do condenado pressupõe um processo de diálogo entre o preso e o Estado" (SHECAIRA; CORRÊA JR, 2002, p. 333), é extrema a dificuldade do preso que, a duras custas, tem cumprido as regras do sistema penitenciário e se vê punido com sua manutenção em regime mais grave. Para ele, o seu bom comportamento era o que bastava, o seu afastamento da atividade criminosa e o cumprimento correto da pena era o suficiente para sua aproximação da liberdade.

A nossa experiência com o regime aberto ${ }^{160}$, inclusive, nos faz crer que este regime, quando efetivamente cumprido, possui uma severidade desconhecida pelo mundo jurídico dos gabinetes. Tendo que se recolher todas as noites na Casa do Albergado (art. 115 da LEP), apesar de dificuldades com transporte, em um emprego precário, voltando a conviver com o mesmo ambiente social, problemas familiares e o estresse do dia a dia que anteriormente, no momento da prática delituosa, podem ter sido fatores desencadeantes do crime, o preso do regime aberto deve superar todos esses obstáculos, somados agora ao estigma de condenado, e cumprir as regras do sistema carcerário.

Para Haroldo Caetano da Silva, há vários anos promotor de justiça atuando na execução da pena, os regimes aberto e semiaberto "na realidade são instrumentos talvez mais

\footnotetext{
${ }^{159}$ Apesar de a pesquisa jurisprudencial neste trabalho ter se baseado na busca do uso do termo ressocialização como obstáculo para a efetivação do princípio da legalidade, importa referir posicionamento do TJMG, seguindo parecer do Ministério Publico, por ser decisão que se sobressai frente a tantas outras contrárias e por ser semelhante ao que se ora defende: "Como bem ponderou o culto Procurador, Dr. Cláudio Fleury Barcellos, a progressão direta para o regime aberto '...não deve ser vista como uma condenável progressão 'por salto'; como se estivesse sendo 'violado' o propósito de ressocialização gradual do condenado...; mas como verdadeira remissão devida pelo Estado como forma de compensação pelo excesso na execução que esteve impondo ao condenado..." (Ag. Ex. no 1.0000.06.444954-9/001, Rel. Des. Edelberto Santiago, j. 13/02/2007). Registre-se também posicionamento do mesmo desembargador no sentido de que o tempo da progressão para o regime aberto seja contado desde a data em que o apenado tinha o direito para o regime semiaberto e não da data na qual efetivamente foi removido para este regime: Ag. 10000.07.463057-5, j. 18/12/07. No mesmo sentido no TJMJ: Ag. 1.0000.07.464797-5, 3ª Cam. Crim., Rel. Paulo Cézar Dias, j. 22/01/08; Ag. 1.0000.08.486444-6, $1^{\text {a }}$ Cam. Crim., Rel. Des. Delmival de Almeida Campos, j. 07/04/09; Ag. 0356942-93.2010.8.13.0000, $1^{\text {a }}$ Cam. Crim., Rel. Des. Flávio Leite, j. 16/11/10.

${ }^{160}$ Como titular da Vara de Execuções Penais do Amazonas, o autor acompanhou a instalação e o funcionamento da ICasa do Albergado de Manaus desde 1999 (LAURIA; VALOIS, 2010).
} 
perversos para a personalidade do condenado do que o próprio regime fechado" $(2009$, p. 61) porque exigem do ser humano um desprendimento voluntário da liberdade, tendo em vista o imprescindível retorno voluntário ao estabelecimento penal. Tal desprendimento, para o autor citado, aproxima mais esses regimes, em tese menos graves, de um caráter retributivo da pena do que ressocializador.

Não há casas do albergado na maior parte do país, como também são poucas as colônias para regime semiaberto. O projeto ressocializador tem ficado só no papel, mas os argumentos das decisões, embora possam estar encobrindo outro fundamento, continuam confirmando a crença no ideal ressocializador. Assim, não é difícil imaginar que a interpretação seja mais rigorosa porque leva em consideração a ausência de Casas do Albergado.

PENA - CUMPRIMENTO - REGIME SEMIABERTO. Incumbe ao Estado aparelhar-se visando à observância irrestrita das decisões judiciais. Se não houver sistema capaz de implicar o cumprimento da pena em regime semiaberto, dá-se a transformação em aberto e, inexistente a casa do albergado, a prisão domiciliar. (STF, HC 96169, Rel. Min. Marco Aurélio, $1^{\text {a }}$ Turma, j.25/08/2009).

A justa decisão do STF, no sentido mais transparente da palavra, não é sempre seguida, e o preso, antes de seu processo chegar à corte localizada no Distrito Federal, tem sido mantido em regime mais rigoroso, visto que há entendimentos de que a concessão de regime semiaberto ou aberto, ou seja, "o deferimento de tal benesse, sem que haja controle ou fiscalização por parte da Administração, como tem ocorrido, traduziria - aqui sim - verdadeira ilegalidade, tirante o sentimento de impunidade pelo crime praticado" (TJSP, 16 Cam. Crim., HC no 990.10.353751-3, Rel. Des. Almeida Toledo, j. 26/10/10) ${ }^{161}$.

Dizer que direitos são benesses ou benefícios "como desculpa para a imposição de uma reprimenda evidentemente maior do que a adequada" (GOMES, 2003, p. 178), ou para a execução da sanção de forma mais grave do que a prevista em lei, é algo dantesco, e não é de se duvidar que a progressão por saltos também esteja sendo negada, não com base no argumento ressocializador que vem expresso nessas decisões, mas com o apoio em sentimentos completamente dissociados do que pode se entender por jurídico.

\footnotetext{
${ }^{161}$ Cumpre anotar que, no presente caso, o paciente estava há mais de 7 meses em regime fechado, aguardando vaga em estabelecimento de regime semiaberto, apesar da progressão deferida, tendo a decisão negado o habeas corpus que solicitava fosse o mesmo mantido em prisão domiciliar até o surgimento da vaga. Vale ressaltar o voto divergente do juiz Souza Nucci, no sentido de que o preso aguardasse em prisão domiciliar.
} 
No que diz respeito à questão de vaga em estabelecimento deste ou daquele regime não entendemos porque até hoje este problema não foi resolvido de forma abrangente, verdadeiramente sistemática. A solução dada pelo judiciário caso a caso, seja mantendo o preso em regime mais grave aguardando vaga, seja enviando-o para prisão domiciliar, não nos parece a forma mais adequada de amenizar o problema.

$\mathrm{O}$ que se demonstra mais coerente seria que o preso com direito à progressão fosse imediatamente transferido para o regime do qual é merecedor e, caso não haja vaga por causa de lotação, que seja concedida prisão domiciliar para o preso que está neste local lotado há mais tempo ou para o preso que está mais próximo de obter liberdade ou uma nova progressão, conforme o caso.

Outra observação prática se impõe com relação a tais decisões, que negam a progressão de regime de presos que cumpriram boa parte da pena sob prisão cautelar. Quando são decisões que cassam progressões concedidas em primeira instância, a violência é maior e a contradição redobrada. Isto porque o preso no regime aberto, que tem sua progressão revogada, apesar de estar cumprindo todas as regras do sistema, acaba recebendo esta revogação como uma verdadeira regressão de regime.

A regressão de regime referida nos casos do art. 118 da LEP se dá quando um preso descumpre regras do regime em que se encontra ou comete outro delito. Os presos são conhecedores dessa sistemática e sabem dos motivos que podem levar à regressão, portanto a revogação da decisão que concedeu progressão, fazendo com que o preso seja transferido para regime mais grave, apesar do cumprimento de todas as regras do sistema penitenciário ${ }^{162}$, é para o preso uma violência incompreensível. Nesse caso, até nos locais onde não há casa do albergado, o sentimento de injustiça permanece, pois o condenado que está em liberdade, cumprindo as exigências impostas no regime aberto e, principalmente, mantendo-se afastado da atividade delituosa, não compreenderá jamais a regressão repentina.

\footnotetext{
${ }^{162}$ Exemplo: "AGRAVO EM EXECUÇÃO - Sentenciado progredido ao regime aberto, sem o cumprimento de 1/6 da pena no regime intermediário - Insurgência do Ministério Público - Decisão cassada para que o condenado retorne ao regime semiaberto..." (TJSP, Ag. Ex. no 990.10.146311-3/Bragança Paulista, Rel. Des. Almeida Sampaio, j. 19/07/10)
} 


\subsubsection{Livramento condicional}

Não para entender, porque a confusão no sistema é enorme, mas para vislumbrar melhor a falta de uma harmonia mínima no ordenamento, cada vez mais pobre de princípios e, consequentemente, de orientação, vejamos o que ocorre com outro direito do preso inerente à execução penal: o livramento condicional.

O livramento pode ser concebido como humanizador, por diminuir o tempo de encarceramento, ou ressocializador, por favorecer o cumprimento da sanção no meio social. Já foi considerado, como a progressão de regime, medida de defesa social pelos mesmos motivos de humanização e ressocialização. No entanto, ao alertar sobre a topografia do Código Penal, que inclui o livramento condicional no Título das penas, Miguel Reale Júnior esclarece que:

a orientação, portanto, em submeter o livramento condicional ao Título que disciplina as penas traduz no sistema português como no nosso, a índole penal do instituto. Não é certamente uma pena com as características que lhes são próprias mas é, na verdade, uma medida penal (REALE JR; et. al, 1985).

É, então, uma medida penal alternativa à pena de prisão. Com o livramento condicional o legislador entendeu por bem abreviar parte do tempo de encarceramento, admitindo o convívio social do apenado antes do término da sanção e mantendo certo controle de suas atividades na forma de restrições.

Embora deva ser aplicado no final da execução da pena, não integra o sistema progressivo de cumprimento da pena privativa de liberdade. Assim é indiferente estar o apenado no regime fechado, semiaberto ou aberto: se preencher os requisitos do livramento condicional deverá ser posto imediatamente em liberdade.

Estabelece o Código Penal que o livramento condicional poderá ser concedido a pena privativa de liberdade igual ou superior a dois anos, desde que: "I- cumprida mais de um terço da pena se o condenado não for reincidente em crime doloso e tiver bons antecedentes; II cumprida mais da metade da pena se o condenado for reincidente em crime doloso" (incisos do art. 83 do $\mathrm{CPB}$ ); há ainda a regra, para a prática de crime hediondo que requer tenha o apenado cumprido mais de dois terços da pena, vedado o livramento para o condenado "reincidente específico em crimes dessa natureza", conforme dispõe o inciso V do art. 83 do Código Penal Brasileiro. 
Nosso interesse não é discutir os requisitos subjetivos, mas tão somente demonstrar que o legislador tratou do livramento condicional de forma diferente do sistema progressivo. E não podia fazer de outra forma, já que cumprimento de pena privativa de liberdade é uma coisa e medida penal alternativa, a ser cumprida em meio livre, é outra.

Contudo, há decisões que, para negar o livramento condicional, colocam-no como fase do sistema progressivo da pena privativa de liberdade, argumentam sobre a vedação acerca da progressão por salto e mantêm o cidadão em regime mais grave:

AGRAVO EM EXECUÇÃO - deferimento da progressão de regime prisional do regime fechado para semi-aberto - Indeferimento do livramento condicional - Não é adequado a passagem direta do regime fechado para o livramento condicional sem o estágio no regime semi-aberto - Necessidade de maior assimilação da terapêutica penal - Recurso improvido (TJSP, Ag. Ex. n 990.09.091464-5, 16 ${ }^{\text {a }}$ Câm. Crim, Rel. Des. Edison Brandão - v. u. - j. em 15.09.09).

Note-se, e foi por esse motivo que trouxemos a presente decisão: agora já não há mais aquela frase um sexto no regime anterior, que tecnicamente fez a maioria dos tribunais negar o direito de o preso passar para o regime aberto, apesar do cumprimento de sua pena quase completo sob custódia cautelar. Nem tecnicamente há como se encontrar uma justificativa para se obstaculizar o livramento condicional quando o preso já cumpriu o tempo suficiente para tanto e não possui qualquer mácula que lhe possa ser atribuída como comportamento inadequado. Por isso, agora, o único argumento é a terapêutica penal - e não podemos deixar de observar quanto seria bom se o magistrado que prescreveu esta terapêutica visitasse, como um bom médico, o paciente de vez em quando.

Felizmente e diferentemente da progressão de regime, a decisão acima, apesar de ser unânime, não reflete o posicionamento da maioria dos tribunais, nem mesmo dos magistrados paulistas, contudo ainda assim há julgamentos no mesmo sentido ${ }^{163}$.

No quesito livramento condicional, a diretriz do STF é seguida sem muitas divergências no Brasil:

EMENTA: EXECUÇÃO CRIMINAL. Pena de reclusão. Livramento condicional. Deferimento antecipado pela sentença e revogação em recurso. Recálculo para eventual progressão de regime. Desnecessidade. Cumprimento de mais de $2 / 3$ (dois

163 TJSP: HC no 999.10.233195-4, $5^{\text {a }}$ Cam. Crim., Rel. Des. José Damião Pinheiro Machado Cogan, j. 16/09/10;

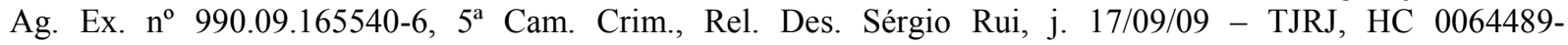
32.2009.8.19.0000, $3^{\text {a }}$ Cam. Crim., Des. Valmir de Oliveira Silva, j. 02/02/10. 
terços) da pena. Benefício deferido. HC concedido para esse fim. Aplicação do art. 83, V, do CP. Provada a coexistência dos seus requisitos, deve o livramento condicional da pena ser deferido em habeas corpus (STF, HC 92897, Rel. Min. Cezar Peluso, $2^{\mathrm{a}}$ T., j. 20/05/2008).

O que ocorre é que a interpretação utilizada para se conceder o livramento condicional poderia muito bem ser a mesma para a progressão de regime, se esta ao invés de ser vista como instrumento ressocializador fosse percebida também como alternativa penal. O tecnicismo judicial que ignora a realidade da pena de prisão massacra mais o ser humano encarcerado e, mesmo se algo de ressocialização pudesse acontecer em quatro paredes, com uma resposta cega do judiciário cria-se mais um obstáculo.

Volta-se a afirmar, realmente há decisões em que a ressocialização vem como argumento favorável ao sentenciado. Natural, pois um pensamento que tem como fundo o interesse humanizador da pena privativa de liberdade deveria mesmo exclusivamente servir para uma interpretação favorável. Contudo, como vimos afirmando, a palavra ressocialização, sempre que é usada em benefício do preso, pode ser substituída tranquilamente por dignidade da pessoa humana, sendo desnecessário um termo que de tão obtuso tem sido usado como instrumento encarcerador.

Com esta alteração, fazendo valer o princípio da dignidade da pessoa humana na prática judicial, não haveria tanta interpretação negativa em prejuízo do preso. Ou será que algum magistrado teria a ideia de dizer que o livramento condicional, ou a progressão de regime, não poderiam ser concedidos ao preso, apesar do tempo de prisão irregularmente cumprido em uma cadeia pública, em nome da dignidade da pessoa humana? Cremos que não.

Saindo das suposições, o que estamos vendo é uma prática jurisdicional longe de um conteúdo comunicativo, muito menos ressocializadora do que a própria pena de prisão. Enfim, as decisões estudadas mais agravam a injustiça do sistema, vedam qualquer diálogo, fazendo da pena privativa de liberdade violência pura, pior do que retribuição e, o que é mais incoerente, com o uso do argumento ressocializador. 


\subsection{EXAME CRIMINOLÓGICO OU POSITIVISMO (DEFENSISMO SOCIAL) CRIMINOLÓGICO}

Antes de falar de tema como o exame criminológico é imprescindível localizá-lo na história, por ser exame que se confunde com o movimento criador do ideal de ressocialização, ou seja, é atividade com origem no pensamento positivista de estudo do criminoso. Por mais que seja afirmada e reafirmada tal conclusão, a respeito do vínculo desse exame com o positivismo, achamos por bem demonstrá-lo, buscando conexões diretas que efetivamente comprovem tal asserção.

Recorrer-se à história em execução penal é extremamente salutar e deveria ser uma constante em qualquer trabalho neste campo, pois a superação de práticas punitivas arcaicas só pode se dar com a consciência de que o momento histórico assim determina.

Contudo, o que pretendemos neste capítulo não é um combate ao exame criminológico, porque ele existe na lei e como toda norma legal deve ser interpretada de acordo com os fatos e circunstâncias atuais. Assim, procuraremos dar um sentido ao exame criminológico que se adéque ao Estado Democrático de Direito e favoreça o respeito ao princípio da legalidade da pena.

\subsubsection{A CTC e o trabalho interdisciplinar}

Falávamos que o sistema punitivo foi edificado sob bases de um projeto ressocializador, por isso é bom avaliar a distância existente entre o que foi esboçado, que é lei, e a realidade. Desde o primeiro dia em que um cidadão é detido pela polícia, passando por seu recolhimento na delegacia, até a sua transformação em preso e, posteriormente em condenado, há violações da lei. Ou seja, o abandono do projeto terapêutico se constitui numa execução penal fora do nulla poena sine lege. O que temos na prática penitenciária é uma verdadeira poena sine lege.

Mas segue-se fazendo de conta estar em um Estado Democrático de Direito - também mais um projeto do que uma realidade - muitas vezes com a consciência tranquilizada pela mídia sempre a informar: são criminosos, diferentes, nós somos os normais, cumpridores da lei. Mas não é verdade. Se todo descumprimento de regra da lei penal fosse crime, a sociedade 
representada pelo Estado era mais criminosa do que qualquer um; só para ficar na Lei de Execução Penal, em cada página há no mínimo um dispositivo que não é cumprido, normalmente em prejuízo de quem está preso.

Machado de Assis estava certo ao afirmar; "Tal é a nossa concepção de legalidade; um guarda-chuva escasso, que não dando para cobrir todas as pessoas, apenas pode cobrir as nossas; noutros termos, um pau de dois bicos" (p. 90). E basta ingressar no sistema punitivo para ficar bem longe desse guarda-chuva. Mesmo o nome cidadão soa diferente quando se fala de execução penal, apesar de se estar falando de preso que, em tese, está pagando pelo que fez e, também em tese, não deve nada mais além disso.

Deixemos a atividade externa da polícia de lado. Não falaremos aqui das inúmeras invasões de domicílio nas periferias, na abordagem policial, no passeio de camburão, no ingresso na delegacia, nem nos procedimentos inquisitoriais, que começam a despersonalização e o fim completo do resto de cidadania do preso. Iniciaremos da própria Lei de Execução Penal, do estatuto penitenciário, da nova Constituição Federal, do novo ordenamento jurídico e das novas regras de condomínio do antigo cidadão, agora preso.

Sem distinção de natureza racial, social, religiosa ou política (art. $3^{\circ}$ da LEP) o preso condenado, antes de ingressar em um estabelecimento penal de cumprimento de pena, deveria ser encaminhado para um Centro de Observação (art. 96 da LEP), onde se elaboraria um exame criminológico, no caso de condenação a regime fechado ${ }^{164}$, com dados para "uma adequada classificação e com vistas à individualização da execução" (art. $8^{\circ}$ da LEP), exame que seria encaminhado para uma Comissão Técnica de Classificação - CTC, formada por um psiquiatra, um psicólogo, um assistente social, além do diretor e de dois chefes de serviço, existente em cada estabelecimento penal (art. $7^{\circ}$ da LEP).

São poucos os centros de observação no Brasil, mas, segundo o esquema traçado pela lei, "enquanto a CTC atua no local da execução, como observatório do cotidiano do apenado, o COC tem por função realizar exames criminológicos mais sofisticados, com intuito de auxiliar os órgãos da execução" (CARVALHO, 2009, p. 142). Diz a lei ainda que, na falta do Centro de Observação, o referido exame pode ser realizado pela própria CTC (art. 98 da LEP),

\footnotetext{
${ }^{164}$ Facultativo para o caso de regime semiaberto (parágrafo único do art. $8^{\circ}$ da LEP).
} 
de onde se depreende, porque a lei não deixa expresso, que caso haja um Centro de Observação, este deve ser constituído por profissionais com a mesma qualificação técnica daqueles que compõem a CTC.

Embora a lei também não especifique o objetivo dessa classificação, nem dessa individualização, deve-se presumir, partindo do pressuposto de estarmos lidando com a delicada situação de perda da liberdade, que tanto uma quanto outra devem ser baseadas e direcionadas para as atividades, assistências e deveres previstos em $1 \mathrm{ei}^{165}$. Assim, a classificação e a individualização administrativa da execução penal deveriam equacionar as atividades dentro do estabelecimento penal, verificar e programar as diversas assistências previstas em lei (do art. 10 ao art. 27 da LEP), orientar sobre os deveres e a disciplina durante o cumprimento da pena, assegurando-se todos os direitos não atingidos pela sentença ou pela lei (art. $3^{\circ}$ da LEP).

Diz a Exposição de Motivos da LEP, que não é e nem tem força de lei, porque mais uma vez a própria LEP não disse, que o exame criminológico se distingue do exame da personalidade "como espécie do gênero. O primeiro parte do binômio delito-delinquente, numa interação de causa e efeito, tendo como objetivo a investigação médica, psicológica e social, como reclamavam os pioneiros da Criminologia" (Item 34). Logo o exame criminológico é uma atividade interdisciplinar e não um exame exclusivamente psicológico, como se poderia supor por ser uma espécie do gênero exame da personalidade.

Aliás, o próprio exame da personalidade que seria feito por intermédio de "esquemas de maior profundidade nos campos morfológicos, funcional e psíquico" (Idem), igualmente, pela leitura da LEP, deveria ser um exame interdisciplinar, porque previsto para ser realizado pela CTC (art. $\left.9^{\circ}\right)$.

E na atividade interdisciplinar não prevalece nenhum tipo de conhecimento. Alvino Agusto de Sá lembra quando esse tipo de atividade começou a surgir na prática penitenciária: “todos profissionais e seus respectivos estudos se colocavam em pé de igualdade na discussão

\footnotetext{
${ }^{165}$ Lélio Lauria Ferreira, referindo-se a Montesquieu, sobre o conceito de individualização administrativa, explica que no século XVIII o filósofo francês já esboçou a ideia de uma pena que se adequasse "“às exigências educacionais e morais de cada um (2005, p. 23).
} 
e na conclusão" (2007, p.172). Contudo, o mesmo autor indica o que causa grande dificuldade na promoção de tal interdisciplinaridade: a questão da segurança.

Note-se que na CTC está prevista a presença de dois chefes de serviço e normalmente ao menos um deles é ligado à segurança do estabelecimento penal, enquanto que o diretor, presidente da comissão (art. $7^{\circ}$ da LEP), se não é um militar, tem sua administração subordinada aos altos comandos de uma secretaria de Estado sempre mais preocupada com a questão da segurança (assunto da mídia), do que com direitos do preso. Quer dizer, nem tanto segurança, mas aparência de segurança: basta que não haja rebelião nos jornais ou fugas a serem noticiadas, o resto pode acontecer no interior do cárcere, e sempre acontece.

Por isso que fazer os profissionais de segurança abrirem "mão de suas predisposições negativas em relação aos internos, do domínio que querem ter sob a prisão, por meio da manutenção da hegemonia da segurança, pela qual eles mantêm a hegemonia de seu poder" (SÁ, 2007, p. 173) é algo quase impossível na conjuntura cultural e política em que está inserida a prisão.

O que sói acontecer é justamente o contrário, com profissionais da área de saúde disputando essa hegemonia de poder em área diversa da sua formação, situação bem descrita por Foucault (1998). Muitos, vendo obstaculizado o seu trabalho, para desenvolver alguma atividade saudável profissionalmente, nem tanto para o preso, mas para si mesmos, são obrigados a compactuar com inúmeras exigências de segurança, que quando não orientam a sua atividade, limitam-na exageradamente. Outros, já trazendo preconceitos de fora, ao ingressarem no estabelecimento penal, embarcam na onda disciplinar que faz da segurança o mote principal.

Há profissionais excelentes, também na área de segurança, é verdade, mas conseguir que estes estejam todos no mesmo lugar, na mesma administração e com idêntica postura de cooperação, dispostos a enfrentar a ideologia da aparência de segurança, sem serem demitidos por estarem indo contra a política do alto comando da secretaria de Estado, é algo difícílimo, para não dizer novamente impossível. Soma-se a isso o fato de que são profissionais extremamente mal pagos e que exercem suas funções em condições materiais precárias, em um ambiente cercado de violência, dissimulação e tristeza. 
Em países com grande capacidade econômica, como EUA, Alemanha e Espanha, onde as funções desses profissionais não admitem um pagamento irrisório, o gasto com os salários somado aos poucos resultados no tratamento penitenciário chega a ser apontado como causa do abandono do ideal de ressocialização (CONDE, 1994), ou seja, a dispensa ou diminuição de importância do serviço desses profissionais se generaliza no mundo todo, dado que reforça o que dissemos anteriormente sobre a falsa crença de que não há ressocialização somente no Brasil.

Esses profissionais não estão livres também de chegarem ao estabelecimento penal já com a postura de juízes, porque são seres humanos vindos de uma sociedade confusa, perplexa no que se refere ao crime e ao criminoso. "Muitos juízes de plantão compõem a vasta fauna de juízes paralelos que são todos aqueles que se julgam capazes de decidir sobre as condutas alheias com o mesmo vigor de uma sentença transitada em julgado” (DOTTI, 2003, p. 275) (Grifo no original). Tal fato dificulta o trabalho em equipe, causando certament distorções no resultado da atividade da CTC e consequentes equívocos na individualização da pena, em prejuízo do apenado.

Os problemas não param por aqui. Quando superados esses obstáculos, a variação das posturas política ou administrativa do alto comando do Estado pode desestabilizar o trabalho em conjunto dos profissionais da CTC, fazendo cessar a colaboração que é deveras importante. A mudança de diretriz, a demissão de um membro, a diminuição de recursos humanos e materiais, o menosprezo para com a atividade da equipe ou a supervalorização de um profissional em especial, condutas administrativas tomadas de forma arbitrária, são inúmeras as circunstâncias que podem influenciar no equilíbrio necessário ${ }^{166}$.

O descaso para com o trabalho em conjunto desses profissionais que por lei compõem a CTC faz com que seja assumido como correto algo equivocado. Segundo relatório do Conselho Federal de Psicologia, intitulado A prática profissional dos (as) psicólogos no

\footnotetext{
${ }^{166}$ Há igualmente o caso de profissionais da área social ou psicológica que são chamados a cooperar em outras áreas relacionadas à segurança, afastando-os de suas verdadeiras funções: "inside a prison, where not only has a clinical team, consisting of psychiatrist, psychologist, and social worker, to be welded together effectively, but where each has often to co-operate fully with other prison officials - the governor, prison and after-care officers, and so forth" (ANDRY, 1965, p. 128). Tradução livre do autor: "em uma prisão, onde não somente a equipe clínica, constituída de psiquiatra, psicólogo e técnicos da área social, é montada efetivamente para trabalhar em conjunto, mas onde cada membro muitas vezes é chamado para cooperar inteiramente com diversos outros agentes prisionais".
} 
Sistema Prisional (2009), na atividade cotidiana dos estabelecimentos penais o psicólogo “elabora um relatório de avaliação psicológica, o qual é encaminhado à Comissão Técnica de Classificação (CTC), onde, em equipe multidisciplinar, elaboram o Plano Individualizado de Tratamento (PIR)" (p. 17).

Maria Palma Wolff verificou que, no Rio Grande do Sul, por exemplo, "o trabalho do Serviço Social e da Psicologia tem-se restringido à elaboração dos pareceres que, por si só, não representam o resultado do programa individualizador de tratamento ao qual o preso deveria ter sido submetido desde a sua entrada" (2006, p. 23).

Volta-se a frisar, a LEP sinaliza para um trabalho interdisciplinar e não multidisciplinar, onde cada profissional prepara o seu laudo ou parecer e encaminha para uma decisão final dissociada da participação de todos. Quando a LEP cria a figura do presidente da comissão (art. $7^{\circ}$ ), entende que esta comissão tenha um coordenador e que o grupo se reúna para, em conjunto, traçar os planos de classificação e individualização na execução da pena.

A prática de deixar a cargo da direção ou de qualquer outro profissional a decisão final sobre a ação a ser tomada no interior do cárcere, favorece seja este parecer utilizado, interpretado, desvirtuado, de acordo com o interesse da pessoa que manuseia o documento. $\mathrm{O}$ psicólogo sozinho, o assistente social sozinho ou um advogado sozinho, apenas verão a situação do preso sob a ótica de suas disciplinas; já em conjunto contribuir para formar uma maior compreensão daquele ser humano preso.

Talvez por isso também tenha ocorrido uma certa psicologização da atividade da CTC, pois com base no parecer do psicólogo é sempre mais fácil buscar subsídios que favoreçam esta ou aquela posição. O parecer do psicólogo, neste caso, é muitas vezes manipulado pela direção ou mesmo pelo juiz, para favorecer a política do encarceramento. Nunca é demais repetir: a Lei de Execução Penal não previu tal conduta. O psicólogo compõe uma equipe e em equipe, para formar conhecimento e diretrizes, deveria trabalhar.

Chegamos a um ponto em que se devem abrir parênteses. A defesa que se faz aqui da atividade da CTC é que esta funcione dentro dos parâmetros de legalidade. A evolução do conhecimento e a realidade demonstraram a inviabilidade de tratamento penitenciário que favoreça o convívio social, apesar de a LEP ter sido estruturada dentro destes parâmetros, ou 
seja, ainda com base na crença no tratamento. Contudo, a interpretação da lei deve ser histórica e subordinada aos fatos, sendo imprescindível que se dê uma função ao exame criminológico dentro de critérios que respeitem a legalidade.

Exame criminológico pode não ter sido um nome feliz para designar o instrumento de individualização da pena, por não facilitar a pretensão de se respeitar o preso como uma pessoa normal. É um exame cujo nome já traz uma certeza, a certeza do crime, o que nem o processo nem a sentença condenatória nos trazem. A certeza processual serve para nos dar o mínimo de segurança jurídica e não uma segurança médico psicológica. Mas o exame está previsto em lei, cabe utilizá-lo da forma mais correta possível.

Assim, dentro da atividade interdisciplinar prevista em lei, o exame criminológico, a classificação e a individualização da pena, devem ser procedimentos realizados em grupo, pela Comissão Técnica de Classificação ${ }^{167}$, sem que se dê ênfase a esta ou àquela disciplina. Nunca esquecer que o exame criminológico, apesar da previsão de que seja realizado em centros de observação, na forma do art. 98 da LEP, pode ser realizado pela CTC, procedimento adotado na maior parte do Brasil, devido à quase completa ausência dos centros de observação. Mesmo as CTC's são raras e, quando existem, são deficientes (SÁ; ALVES, 2009, p. 8).

Note-se que não estamos fazendo nenhuma defesa de critérios subjetivos para a vedação ou concessão de direitos. Como se verá, o que pretendemos é o oposto. A prisão, enquanto existir, é um ambiente de convivência de seres humanos, com suas diferenças, seus problemas e, nesse local principalmente, com suas dores. Assim deixar que esta coexistência de pessoas seja regulada com base somente em critérios de segurança não é inteligente nem legal. A CTC, por lei, deveria cumprir este papel, todavia, na prática, está distante desta função.

\subsubsection{Positivismo e subjetivação a cargo da medicina}

Dissemos no subitem anterior que a atividade da CTC deve ser interdisciplinar, ou seja, que todos seus membros devem laborar em grupo. Conclusão que pode ser tirada do texto da

\footnotetext{
167 Nunca esquecer que o exame criminológico, apesar da previsão de que seja realizado em centros de observação, na forma do art. 98 da LEP, pode ser realizado pela CTC, procedimento que é adotado na maior parte do Brasil, devido à quase completa ausência dos centros de observação. Mesmo as CTC's são raras e, quando existem, são deficientes (SÁ; ALVES, 2009, p. 8).
} 
própria LEP, mas que não condiz com a realidade penitenciária. O que fizemos foi simplesmente uma interpretação da LEP sob a ótica do respeito à dignidade do preso, com base no princípio da legalidade.

O passado e o presente são provas de que uma das áreas mais férteis para criação de comissões é a penitenciária. Desde que se começou a falar em sistema penitenciário há a presença de uma comissão para algum tipo de atividade. O regulamento da Casa de Correção do Império ${ }^{168}$ (Decreto $\mathrm{n}^{0} 678$, de 6 de julho de 1850) já tinha a sua comissão, chamada Comissão Inspectora, que, em comum acordo com o diretor deveria proceder à classificação dos presos, tendo em vista "a natureza da pena e do delicto, a idade e moralidade do delinquente, e seu comportamento na prisão" (art. $4^{\circ}$ ).

O restante da competência da dita comissão vinha no art. 113 do regulamento citado:

Compete á Comissão reunida: $1^{\mathrm{o}}$ Proceder, de accordo com o Director do Estabelecimento, á primeira classificação dos presos, de que trata o Art. 6; $2^{\circ}$ Resolver, se devem por-se ferros á algum preso no caso do Art. 46, dando immediatamente conta ao Chefe de Polícia; $3^{\circ}$ Revogar ou modificar as penas disciplinares impostas pelo Director, quando forem oppostas ou não conformes ao Regulamento, dando parte immediatamente ao Chefe de Polícia; $4^{\circ}$ Apresentar ao Ministro no fim de cada mez hum relatório circumstanciado do estado da Casa de Correção com as indicações, que lhe occorrerem tendentes á execução do Regulamento, e em geral ao melhoramento da Instituição. Este relatorio deverá publicar-se pela imprensa; $5^{\circ}$ Tomar conhecimento das faltas, que possão ter havido a respeito do preso, que vai ser posto em liberdade, e providenciar como convier nos limites de suas atribuições, representando no que as exceder; $6^{\circ}$ Examinar especialmente huma vez em cada mez a escripturação e contabilidade do Estabelecimento e dar balanço á respectiva caixa, averiguando, se as obrigações do Director a respeito do peculio dos presos tem sido fielmente cumpridas" (ROIG, 2005, p. 198-199).

Portanto, esta comissão do período imperial, que tinha entre suas atribuições resolver se deveriam ser postos ferros a algum preso, é o antepassado brasileiro mais antigo da CTC. As atribuições de classificação, de conhecer sobre as faltas dos presos, atuando sobre as sanções disciplinares e sobre o pecúlio, são suficientes para que se perceba a influência de todos os penitenciaristas, correcionalistas ou humanistas penitenciários, muitos dos quais já foram referidos, e que fizeram carreira após Beccaria e John Howard ${ }^{169}$.

\footnotetext{
${ }^{168}$ Segundo Carlos Aguirre, a Casa de Correção do Rio de Janeiro foi a primeira penitenciária da América Latina (2009)

169 “A preocupação com a prisão é muito importante para se deixar completamente a cargo do diretor: pago para dar assistência, mas muitas vezes tentado por suas paixões, ou interesse, falha na sua obrigação". Em ingles
} 
São Paulo também possuiu sua Casa de Correção em 1852, com as mesmas preocupações da instituição da corte, mas ambas as prisões não eram regra e o padrão higiênico e disciplinar não foi seguido no restante do país: "as duas casas de correção ficaram sendo por longos anos exceções em meio aos cenários dantescos e imutáveis que as cadeias espalhadas pelo país continuavam a exibir" (SALLA, 1999, p. 66). A Comissão Inspetora, que existia igualmente na instituição paulista, não teve vida longa e como muitos outros projetos penitenciários logo perdeu sua função de controle da administração e das penas, retornando tudo para o seu antigo lugar, ou seja, para o arbítrio do diretor (Idem, Ibidem).

O que foi dito acima sobre a psicologização do exame criminológico também faz parte de um processo histórico. O médico foi o primeiro a entrar no ambiente prisional, no início somente por questão de higiene e saúde dos presos, depois como auxiliar do próprio poder judicial. A observação, a disciplina e a classificação de presos não fazem parte de um projeto médico, mas foram úteis à ampliação da importância da medicina no âmbito penitenciário.

Da saúde física à psiquiatria, diante da necessidade de se detectar os anormais que não se enquadravam nas regras disciplinares, foi um passo: "Foi a reação do prisioneiro à disciplina penal e sua incapacidade em se beneficiar da punição que determinava se ele seria classificado como portador de "problema mental""170 (WATSON, 1994, p. 229). A chegada da psiquiatria forense em uma sociedade estruturada com base no contrato social fez com que se percebesse naquele que descumpre o contrato o anormal. Um ser primitivo, com comportamento anterior ao pacto social, "o criminoso é aquele que, rompendo o pacto que subscrevera, prefere seu interesse às leis que regem a sociedade de que é membro" (FOUCAULT, 2001, p. 115)

Quanto mais as ciências sociais ganhavam ares de ciências exatas, com a crença de que poderiam solucionar os problemas da sociedade com fórmulas predeterminadas, mais difícil ficava a crítica à técnica punitiva, tida como humanizadora. A única explicação para a falha só poderia vir das ciências psi. O sucesso da obra de Lombroso só fez aumentar o número de especialistas sobre o comportamento criminoso, fazendo dos congressos científicos que se

original: "The care of a Prison is too important to be left wholly to a Gaoler; paid indeed for his attendance, but often tempted by his passions, or interest, to fail in his duty" (HOWARD, 1777, p. 66).

${ }^{170}$ Tradução livre de: "It was the prisoner's reaction to penal discipline and his perceived inability to benefit from punishment that determined whether he was classed as "weakminded"”. (WATSON, 1994, p. 229). 
seguiram à publicação de $O$ homem delinquente verdadeiros encontros ecumênicos em um sonho de "uma grande antropologia criminal de essência pluridisciplinar. Antropólogos, biólogos, psiquiatras, médicos-legistas, sociólogos, juristas participam do movimento" $\left(\right.$ DARMON, 1991, p. 84) ${ }^{171}$.

Assim, o positivismo trouxe várias ideias para novas comissões, como exemplo a já citada Comissão de Vigilância proposta por Ferri (1999), que tinha a dupla função de evitar o arbítrio do diretor e servir como instrumento de recuperação do criminoso. Em Garofalo (1997) o próprio júri seria extinto para dar lugar a uma comissão de técnicos, “com maiores garantias do que qualquer outro tribunal" (p. 282) e em caso de alienados, "tem acaso os juristas o direito de contestar uma afirmação feita em nome de uma ciência em que são incompetentes?" (p. 194)

A lição de Mitsuko Antunes é de que a psicologia ganhou força no interior da interação que passou a existir entre medicina legal, psiquiatria forense e criminologia. A autora cita Heitor Carrilho como um exemplo de representante da psiquiatria forense no Brasil, responsável por esse processo de influência positivista, médico que iniciou seu trabalho no Hospital Nacional dos Alienados, atuando na Seção Lombroso, que abrigava os criminosos loucos, e que criou o Manicômio Judiciário do Rio de Janeiro em 1921, tendo sido membro do Conselho Penitenciário, diretor do Serviço Nacional de Doenças Mentais, presidente da Sociedade Brasileira de Neurologia, Psiquiatria e Medicina Legal e catedrático de Clínica Psiquiátrica na Faculdade Fluminense de Medicina. Como crítico do Direito Clássico, procurava avaliar o crime "sob o foco da determinação individual e não social. Dessa maneira, o Direito Positivo acabava, em última instância, psicologi-zando ${ }^{172}$ ou individualizando o ato criminoso e sua interpretação" (2007, p. 56).

Luís Ferla (2009) cita muitos outros, explicando, todavia, que os encontros de medicina legal ou antropologia tinham sempre os mesmos nomes. João Vieira teria sido o precursor, em 1884, defendendo uma análise moderna da legislação nacional com base no positivismo. Depois vieram Viveiros de Castro, Paulo Egídio, Cândido Mota, Nina Rodrigues,

\footnotetext{
171 A ilusão ecumênica (o termo é do próprio autor citado) acabou "por se dissipar num rosário de lutas intestinais, cada qual querendo impor a hegemonia de sua própria tendência" (DAMON, 1991, p. 84)

${ }^{172}$ Citado pela autora o trabalho de Fry, Direito Positivo Direito Clássico: a psicologização do crime no Brasil no pensamento de Heitor Carrilho, in: Cultura da psicanálise.
} 
este reconhecido pelo próprio Lombroso como apóstolo da antropologia criminal no Novo Mundo, além de, entre outros, Afrânio Peixoto e Oscar Freire. Médicos catedráticos como Flamínio Fávero, debatiam questões de direito com toda propriedade, atacando os equívocos da Escola Clássica - leia-se equívocos do Direito Penal e suas garantias - em prol do tratamento e de uma visão médica da pena.

Assim começou o século XX na América Latina, com a medicina invadindo o meio jurídico e o espaço penitenciário:

A ciência e, de forma proeminente, a medicina começaram a exercer uma grande influência no projeto dos regimes carcerários, na implementação de terapias punitivas e na avaliação da conduta de presos. Revistas médicas e criminológicas, teses universitárias, conferências internacionais e, especialmente, a implementação de gabinetes dentro das prisões ofereciam a imagem de elites ávidas por estudar o 'problema social' do delito (AGUIRRE, 2009, p. 55).

É bem evidente que a psicologia ingressou no espaço penitenciário por intermédio da medicina. Sua origem neste campo é bem distinta dos belos princípios filosóficos que marcaram seu nascimento na história científica da humanidade. Na penitenciária, a psicologia veio como mais um instrumento de medição, de catalogação, justificador da diferença, do tratamento, da disciplina, mecanismo médico de higiene mental.

Nesta e em muitas outras situações ligadas ao sistema penitenciário, a lei vinha depois para regular ações que já eram praticadas. O direito, sozinho, nunca conseguiu o seu intento de ciência da razão iluminista de abarcar todos os problemas sociais para os quais era chamado. Não só o meio penitenciário era propício para o desenvolvimento dos mais escusos sentimentos de poder e dominação de um ser humano pelo outro, mas também era local onde estavam pessoas que o direito não conseguia compreender e a concepção de ciência não permitia que houvesse dúvidas ou algo que o conhecimento humano não pudesse resolver. Daí terem sido consideradas, a psicologia, a medicina, a sociologia, ciências auxiliares do direito, auxiliares na compreensão do que o poder pura e simplesmente não podia explicar, nem muito menos justificar.

Primeiro foram instalados laboratórios de antropologia criminal junto às instituições policiais. Em 1932 no Rio de Janeiro e em 1934 em São Paulo, ambos para auxiliar na identificação de criminosos, seus laudos e pareceres começaram a ser solicitados por diversas outras instituições como argumento de autoridade para decisões de diversas ordens, desde a 
verificação de sanidade até a concessão de livramento condicional. Em 1940 foi inaugurado o primeiro laboratório de antropologia criminal em uma instituição penitenciária. Seria o Serviço de Biotipologia Criminal da Penitenciária de São Paulo e, segundo o então diretor da penitenciária, Acácio Nogueira, seguindo orientações de Heitor Carrilho, “justificava a criação do laboratório em nome dos novos tempos da 'ciência criminológica', segundo ele expressos pelo que ele chamava de 'neo-lombrosianismo'” (FERLA, 2009, p. 141-142).

A partir de então sempre haveria a ideia da necessidade de uma equipe que realizasse a classificação e individualização da pena. Desde 1933, a maioria dos projetos de código penitenciário ou de execução penal tentou criar, cada um seguindo o perfil do seu autor, um sistema penitenciário científico ${ }^{173}$. A importância da referência a anteprojetos e projetos de códigos penitenciários cresce quando sabemos que a LEP foi produto das discussões e conclusões que se travaram nas comissões dos antigos projetos, informação que se extrai do relatório da Comissão de Constituição e Justiça ao avaliar o projeto $n^{\circ}{ }^{1584}$, de 1983, que se transformaria na Lei 7.210/84, a LEP:

Que é, em verdade, uma síntese construtiva do que foi feito, pensado e avaliado nesses últimos anos que eminentes juristas se voltaram para o estudo da matéria. Se o projeto, como afirmamos, foi o resultado do trabalho de gerações, cada qual oferecendo a sua parcela de contribuição, hoje se apresenta como o coroamento de uma política inspirada em valores humanos impostergáveis - como a liberdade, a dignidade humana, a valorização do trabalho e a defesa da ordem social (BARROS, 1985, p. 565).

No projeto de Oscar Stevenson, de 1957, havia o Serviço de Recuperação, que seria composto pelo diretor do estabelecimento, por um jurista, um psiquiatra, um biotipologista e dois assistentes sociais (art. 48), e tinha por objetivo

\footnotetext{
“o estudo da personalidade dos recolhidos, distribuí-los em classes e grupos, determinando-lhes o tratamento conveniente. A apreciação anamnéstica da personalidade deve atender ao critério multilateral o estudo do indivíduo pelos aspectos clínico, somático, neuropsíquico e psicológico, a abranger pesquisas quanto à vida pregressa, à ambiência familiar, ao nível intelectual e, ainda, às circunstâncias do fato praticado. Daí o juízo sobre a personalidade, a diagnose, a prognose e a indicação do tratamento" (PAUPÉRIO; et. al, 1978, p. 135)
}

\footnotetext{
${ }^{173}$ Para uma visão abrangente da evolução do positivismo na prática policial, judicial e penitenciária, vide a obra de Luis Ferla, Feios, sujos e malvados: a utopia médica do biodeterminismo. São Paulo: Alameda, 2009. Neste trabalho o autor cita o primeiro anteprojeto de Código Penitenciário do Brasil, de 1933, onde havia a previsão de laboratórios de antropologia criminal para as instituições penitenciárias, fazendo referência igualmente à primeira Conferência Penitenciária Brasileira que teve como uma de suas propostas: "a organização de serviço médicoantropológico nos estabelecimentos penais deve ser obrigatória, em face de se orientar o tratamento regenerador dentro do exato conhecimento da personalidade do sentenciado" (2009, p. 141)
} 
O projeto de Roberto Lyra, de 1963, entretanto, recusou tratar o condenado como doente, afirmando, em sua exposição de motivos, não haver "tratamento para crime, que não é moléstia com sua terapêutica ou sua cirurgia. Há, na criminogênese, isto sim, doenças de que padece a sociedade e não os indivíduos" (PAUPÉRIO; et. al., 1978, p. 214). Já o projeto de Benjamim Moraes Filho, de 1970, volta a prever tratamento para o sentenciado, valendo ressaltar deva ser o autor do projeto considerado o idealizador da CTC, uma vez que nas suas disposições havia comissão semelhante, encarregada de avaliar "as ausências e insuficiências da personalidade do sentenciado, aferidas no exame de classificação" ${ }^{174}$. (Idem, p. 271).

Ao se ter notícia de que muitos exames, classificações e medições já eram feitos com o fim de algum tratamento científico em um ou outro estabelecimento penal, independentemente dos projetos de lei, sabe-se também que tais atividades eram, no máximo, realizadas de forma precária e somente nos grandes centros do país. A história científica do sistema penitenciário brasileiro corre paralela à história de abandono desse mesmo sistema.

A LEP foi pioneira em uma questão: em reconhecer o saber do psicólogo, pois até então, todos os projetos de lei faziam referência apenas ao médico, de preferência psiquiatra, como dizia o projeto de 1970. Talvez um indício de que a pena se afastava da ideia de tratamento, no sentido médico do termo, mas, para tanto, seria imprescindível uma conduta do psicólogo neste sentido, o que sempre foi dificultado porque a psicologia parece ainda ter a necessidade de "se afirmar e ser aceita como ciência, tentando estabelecer as conexões causais para explicar e compreender o homem. Os testes contribuíram para o desenvolvimento de uma linguagem padronizada que pudesse ser aceita pelas disciplinas científicas das quais passou a fazer parte" (Tereza I. H. Mito apud SÁ, 2011, p. 294).

Se, quando da elaboração da Lei de Execução Penal, o exame criminológico, como exame de personalidade inicial, para traçar as diretrizes do tratamento penitenciário, já causou

\footnotetext{
${ }^{174} \mathrm{Na}$ verdade, no projeto de Benjamim Moraes Filho havia a previsão de dois órgãos que, juntos, teriam atribuições semelhantes às da atual CTC. Um deles era a Comissão de Classificação e Tratamento, que iria classificar, prescrever tratamento, propor transferência de presos e avaliar os requisitos do trabalho externo; o outro era o Conselho de Classificação e Tratamento, que promoveria a lotação dos presos no sistema, de acordo com o exame de classificação, decidiria sobre as transferências, supervisionaria as atividades da Comissão de Classificação e Tratamento e aprovaria as indicações dos diretores de estabelecimentos penais (PAUPÉRIO, 1978, p. 281).
} 
inúmeros debates, como se depreende da Exposição de Motivos (Item 33), hoje os motivos são maiores para que tal atividade seja vista e praticada sob outros parâmetros.

A avaliação da personalidade do condenado, para os autores da Lei 7.210/84, a LEP, devia ser feita "como recomendam os mais prestigiados especialistas, entre eles Di Tullio" (Item 34). Benigno Di Tullio, titular da cadeira de antropologia criminal da Universidade de Roma, é citado também por Marc Ancel (1979) pelo seu "notável trabalho de defesa social realizado em Rebibbia”(p. 204).

Antes de explicar no que consistia o trabalho efetivado na Itália por este inspirador do exame criminológico brasileiro, um breve resumo da teoria da delinquencia constitucional do autor:

\footnotetext{
"No essencial esta teoria defende a existência de uma estrutura delinquencial - um conjunto de características particulares, subjacentes ao desenvolvimento dos fenômenos criminais - entendido como fator essencial específico da criminalidade. Esta estrutura delinquencial resultaria de uma estrutura particular da personalidade do criminoso, que conteria em si características fisiopsíquicas suscetíveis de favorecer o desenvolvimento de reações criminais, mesmo em face a circunstâncias e instigações exteriores insuficientes, isto é, situadas abaixo do limiar que afetaria a maioria dos indivíduos (...) A partir da estrutura delinquencial, seria possível estabelecer diferentes tipos e subtipos de delinquentes, dando origem a uma nova tipologia, na qual a própria 'constituição criminal' se destacava como o elemento de diferenciação entre os verdadeiros criminosos (os constitucionais) e os criminosos ocasionais ou os criminosos alienados (e semi-alienados)" (MANITA, 2001, p. 40).
}

Muito embora o professor italiano tenha acrescentado em sua construção teórica a influência de fatores ambientais para a prática criminosa, sem muito esforço pode-se ver em sua teoria um neo positivismo lombrosiano acentuado. E impressiona saber que a obra de Di Tullio influenciou a elaboração da LEP, promulgada mais de trinta anos depois das últimas edições de sua obra. Ou seja, o exame criminológico brasileiro é evidentemente de origem positivista, para não dizer igualmente lombrosiana.

A citação de Di Tullio por Marc Ancel, acima referida, se deu pelo trabalho do italiano no Instituto de Rebibbia, onde se davam os primeiros experimentos de exame da personalidade quando do início do cumprimento da pena. Como já ressaltado, a Nova Defesa Social, na concepção de Ancel, englobava várias correntes de pensamento, sempre no intuito de angariar adeptos que seguissem na direção do que era concebido como humanização do sistema penitenciário. 
Alvaro Mayrink, também citado na Exposição de Motivos da LEP (Item 33), explica que, juntamente com o Centre National d'Orientation de Fresnes (1950) na França, o Instituto de Rebibbia (primeiramente um hospital penitenciário, mas depois um conjunto penitenciário com prisão, hospital e centro de triagem) era pioneiro em realizar exame inicial de caráter médico, psicológico e social, antes de ser estabelecido o adequado tratamento do preso. $\mathrm{O}$ sentenciado era "submetido a rigoroso exame ou, como diria Benigno Di Tullio, à 'clínica antropológica' (Di Tullio, Principi de Criminologia Clínica, 1954). A expressão generalizouse. Os médicos de Fresnes também a usam” (MAYRINK, 1982, p. 1457).

Se ainda há dúvidas de que o exame criminológico, ou a clínica antropológica primeiramente elaborada por Di Tullio, tem origem na ideia de uma patologia e visava a uma classificação de natureza médico antropológica com influência da teoria do criminoso nato de Lombroso, deixemos o próprio Di Tullio falar:

Mas tais inovações se relacionam a todo o mais vasto problema da reforma
penitenciária, para a qual é direcionada a atenção dos criminalistas do mundo todo, e
que a cada dia vai aumentando em cada país civil, sempre sob a base dos princípios
fundamentais que a escola positiva italiana, por obra especialmente de Cesare
Lombroso e de Enrico Ferri, difundiu em todo mundo. É sabido por todos que o
movimento que se vai desenvolvendo em tal campo de reforma penitenciária, seja na
América, seja na Europa, é que os mais recentes projetos de reforma são todos
orientados pelo critério da defesa social e da reeducação do delinquente. Começando
na América do Sul, nós vemos que todas as naçães vão preparando a reforma dos
cárceres, para transformá-los em institutos de defesa e de verdadeira
reeducação social, que têm também o objetivo de favorecer o estudo da
criminalidade. E enquanto nas prisões de Buenos Aires já há um serviço de
medicina pedagógica carcerária, no Brasil, no Chile, na Colômbia, etc, já há projetos
de lei estabelecendo reforma penitenciária, orientanda especialmente para a
instituição de serviços de Antropologia Criminal ou médico pedagógicos ${ }^{175}$ (DI
TULLIO, 1929, p. 168) (Grifei).

A longa citação do médico psiquiatra italiano se deve ao fato de que ela é reveladora de outros seguintes aspectos: a) O exame da personalidade inicial que Di Tullio promovia visava

\footnotetext{
${ }^{175}$ Tradução livre de: "Ma tali innovazioni si ricollegano a tuto il più vasto problema della riforma penitenziaria, verso la quale è rivolta l'attenzione dei criminalisti di tutto il mondo, e che ogni giorno si va maggiormente sviluppando in ogni paese civile, sempre sulla base di quei principi fondamentali che la scuola criminológica positiva italiana, per opeara specialmente di Cesare Lombroso e di Enrico Ferri, ha diffuso in tutto il mondo civile. È a tutti noto infatti che il movimento che si va svolgendo in tale campo di riforme penitenziarie, sai in America che in Europa, e che i più recenti progetti di tali riforme sono orientati tutti al criterio della difesa sociale e della rieducazione dei delinquenti. Cominciando dall'America del Sud, noi vediamo infatti che tute le varie nazioni si vanno preparando alla riforma delle carceri, per transformarle in instituti di difesa e di vera rieducazione sociale che abbiano anche lo scopo di favorire lo studio della criminalità. E mentre nelle carceri di Buenos Ayres vi è già um servizio di medicina pedagógica carcerária, nel Brasile, nel Cile, nella Columbia, ecc. sono già pronti dei progetti di legge che stabiliscono la riforma penitenziaria, orientandola specialmente all'instituzione di servizi di Antropologia Criminale o medico-pedagogici” (DI TULLIO, 1929, p. 168).
} 
o estudo antropológico do delinquente; b) A influência direta do positivismo lombrosiano na doutrina de Di Tullio e na sua atividade junto ao sistema penitenciário; c) A pouca distância que havia entre o pensamento de defesa social da escola positiva e a nova defesa social de Marc Ancel; d) A ideologia de tratamento sendo usada como subterfúgio para a reforma do sistema prisional; e) A influência do positivismo na prática e nas legislações da América do Sul e expressamente na brasileira.

Alvino Augusto de Sá considera "óbvia” a atualidade do pensamento de Di Tullio, embasando a atuação das pessoas envolvidas na atividade penitenciária, dando como exemplo "a exigência irrenunciável que muitos juízes de execução têm pela realização do exame criminológico, para nele pautar suas decisões" além do “'fervor” com que juízes se atêm à circustância judicial personalidade, do art. 59, do Código Penal Brasileiro, para se pronunciar na dosimetria da pena" (2011, p. 152).

Ao se ler a Exposição de Motivos da LEP e o vínculo dessa legislação com o antropólogo criminal discípulo de Lombroso, Di Tullio, nos vem a curiosidade de saber um pouco mais sobre os debates que se travaram anteriormente à promulgação de nossa lei penitenciária. Nessa rápida pesquisa, ficamos sabendo que a LEP não foi uma lei previamente discutida, havendo manifestações, publicadas juntamente com o relatório da Comissão de Constituição e Justiça, dando conta de que nem mesmo o correto procedimento legislativo teria sido observado (BARROS, 1985).

Mas o período negro patrocinado pela ditadura militar, que antecedeu a promulgação da LEP, fez com que a inobservância de formalidades, na tramitação legislativa, não fosse levada em conta. A nossa inexperiência democrática também não permitiu que houvesse maiores oposições à falta de debates sobre o novo ordenamento. Assim, pesquisando um pouco mais, chega-se à CPI do sistema penitenciário de 1976, que teve como relator o então deputado Ibrahim Abi-Ackel, o mesmo político que seria o Ministro da Justiça a assinar a Exposição de Motivos da LEP. Não sem justiça, o trabalho de Abi-Ackel foi considerado motivador da reforma da legislação penal de 1984 (CERNICCHIARO, 1998).

O relatório dessa comissão se revela um precioso documento de nossa história penitenciária, embora pouco citado. De sua leitura fica evidente de onde surgiram as balizas da 
LEP, além de ficar demonstrado que pouca coisa mudou na nossa realidade penitenciária passados mais de trinta anos. Limitando-nos ao assunto ora tratado, algumas observações podem ser reforçadas com a leitura desse documento. A primeira é quão realmente a Escola da Nova Defesa Social exerceu enorme influência no legislador de 1984; a segunda é ter sido muito forte o credo na ressocialização científica e consequente humanização da prisão; e a terceira, que o exame criminológico tem inequívoca origem nas ideias dos primeiros positivistas:

\begin{abstract}
Discussões científicas pertinentes à conveniência de se procederem tais exames por institutos de biotipologia criminal ou por centros de observação integrados por equipes técnicas de psicólogos, psiquiatras, criminólogos e assistentes sociais têm sua causa nas concepções antropológicas que assinalam as atividades dos referidos institutos - não há, porém, dentre quantos se dedicam ao estudo da ciência penal, quem subestime os exames da personalidade como requisito para eficácia do tratamento. O exame do sentenciado, orientado no sentido de conhecer sua inteligência, sua vida afetiva, seus princípios morais, sob a ótica do crime praticado é que determinará sua inserção no grupo com o qual conviverá no curso da execução da pena. A ausência de tais exames tem permitido a transferência de reclusos para estabelecimento aberto, sua colocação em regime de prisão albergue e até a concessão de livramento condicional sem que estivessem para tanto preparados, em flagrante desatenção aos interesses da segurança social. $O$ exame inicial da personalidade e o acompanhamento durante o tempo de execução da pena por juntas técnicas de observação devem transformar-se em fontes de decisão para a passagem ao regime de semiliberdade e para a outorga da liberdade condicional (ABI-ACKEL, 1990, p. 14-15).
\end{abstract}

O relatório da CPI que antecedeu a LEP fala inúmeras vezes de tratamento penitenciário, fazendo referência à pena como remédio, mas também propõe diversas medidas descarcerizadoras que deveriam servir para evitar a prisão dos que não necessitassem de tratamento. Pena que de suas propostas, a de tratamento tenha ganhando mais força, em comparação com a de descarcerização. A ênfase no tratamento acabou se transformando em um acréscimo de legitimação para o encarceramento generalizado e irracional, o que em hipótese nenhuma era a ideia do deputado e ministro que articulou a promulgação da LEP, ao menos segundo o texto oficial.

Se é certo que ao longo do século $\mathrm{XX}$ foram produzidas variadas teorias psicológicas que se afastaram da ideia de patologia e aceitaram o ser humano que delinquiu como uma pessoa normal, dando-se uma ruptura com as abordagens psiquiátricas e favorecendo o nascimento de ideias eminentemente psicológicas embasadas em modelos explicativos do 
comportamento (MANITA, 2001), a origem do estudo do criminoso no âmbito penitenciário é de caráter antropológico, partindo de uma concepção de doença atávica.

O tempo que a psicologia tem como ciência é pequeno para que seus erros não sejam mais sentidos, ainda que façam parte da própria evolução científica. Assim, seus estudos sobre o comportamento humano, independentemente da maior ou menor ênfase dada às características biológicas do ser humano, sempre influenciaram os outros campos de saber que igualmente tinham interesse nesse tema.

O professor de criminologia da University of South Florida, Michel Lynch (2007), em seu estudo sobre a indústria prisional norte-americana e as supermax prisons, as grandes cadeias de segurança máxima daquele país, explica que muitas das experiências psicológicas com animais do início do século passado reforçaram a concepção de que a punição pode alterar o comportamento. Os primeiros estudos com animais ${ }^{176}$, diz o professor, levaram à conclusão de que há três formas de se tentar alcançar uma mudança de comportamento: o reforço positivo, o reforço negativo e a punição.

Com relação ao reforço positivo não há problemas. A diferença entre o reforço negativo e a punição é dada por intermédio do exemplo de um cachorro. Se o animal vem sempre roendo um par de sapatos, o seu dono pode colocar pimenta no sapato ou bater no cachorro, sendo que na primeira situação haveria um reforço negativo e na segunda a punição. Quanto à alegação de que o reforço negativo pode ser considerado punição por ser ruim para o cão, o professor informa que a grande diferença entre o reforço negativo e a punição está no tempo. A punição vem depois, distante do fato, enquanto o reforço negativo é imediato. Ressalte-se que, no caso, "o dono do cachorro não quer mudar o seu próprio comportamento"177 (LYNCH, 2007, p. 102).

Pretende-se mudar o comportamento animal, mas o proprietário não quer mudar o seu próprio comportamento. Mais ou menos como a sociedade, suas ciências, suas autoridades legislativas, judiciárias etc, que criam punições novas a todo momento, reformam códigos e

\footnotetext{
176 John B. Watson (1878-1958) foi considerado o fundador da abordagem psicológica conhecida como behaviorismo. Watson pensava ser possível encontrar através do comportamento dos animais repostas para o comportamento humano (PERVIN, 1978).

177 No original: "the owner doesn't want to change his own behaviors" (LYNCH, 2007, p. 102).
} 
penitenciárias, aumentam penas e vedam direitos, tudo em nome do combate ao comportamento criminoso, mas nunca pensam na mudança de sua própria estrutura de exploração e abandono da população. "A inquisitorialidade das técnicas de melhoramento transformou o criminólogo (pesquisador) em sujeito de observação das reações do objeto pesquisado (condenado) aos seus procedimentos laboratoriais de domesticação" (SALO, 2008, p. 67). Com relação ao estudo dos animais, o professor norte-americano conclui da seguinte forma:

O maior problema, entretanto, diz respeito à questão de se os estudos com animais podem ser aplicados diretamente aos humanos. Sem entrar neste mérito, nós podemos dizer que dos três métodos de mudança de comportamento - o reforço positivo, o reforço negativo, e a punição - a punição é o menos efetivo com humanos $^{178}$ (LYNCH, 2007, p. 101).

As ciências fechadas em seus objetos de estudo nunca poderão alcançar toda a complexidade da sociedade e do ser humano. Nunca é demais repetir, o objetivo do conhecimento é um só e sua fragmentação há de ser sempre conhecimento parcial, o que também é ignorância parcial. Dizendo de outra forma, “o homem, que aprendeu a dissecar o objeto de sua observação para entendê-lo, tornou-se um especialista em partes, mas ignorante em relação à totalidade" (PRADO, 2003, p. 1). Muitos de nossos cientistas sabiam disso e queriam apenas contribuir para somar conhecimentos, mas suas parciais descobertas puderam ser usadas arbitrariamente, como certezas.

Já nos alongamos bastante neste assunto, e não nos cabe aqui fazer um resumo de todas as teorias, ou mesmo de classificações de criminosos originadas no século passado. Defendemos simplesmente o fato de que o exame criminológico, como está na LEP, pode e deve ser interpretado de outra maneira, diferentemente de como pensaram os legisladores de 1984. A origem positivista e antropológica do exame, na forma como previsto pelo citado e elogiado Di Tullio, deve ser superada para que se conceba uma atividade interdisciplinar, democrática e direcionada para a garantia de direitos.

\footnotetext{
178 Tradução livre de: "The bigger problem, however, involves whether studies on animals can be assumed to apply equally well to humans. Without belaboring the point, we can say that of three methods for changing human behavior - positive reinforcement, negative reinforcement, and punishment - punishment is the least effective on humans" (LYNCH, 2007, p. 101). A mesma conclusão podemos encontrar em Lila Spadoni, que atribui a Skinner a descoberta, mediante o estudo do comportamento animal, de que "a punição não é o método mais eficiente para eliminar comportamentos indesejados" (2009, p. 41).
} 
A lei não está presa ao momento histórico em que foi elaborada, muito embora a LEP tenha sido promulgada em época que não se justificava mais uma conduta antropológica no seio do sistema penitenciário. A lei tem existência própria e regula as atividades do tempo presente, razão pela qual, como dito no subitem anterior, a ação da CTC tem que ser vista como interdisciplinar.

Em um Estado Democrático de Direito não há espaços para ditadores, sejam eles governantes ou diretores de estabelecimentos penais. Democracia é prática que deve ser exercitada, caso contrário, não se desenvolve ou se atrofia. Dentro da LEP, e mesmo na conduta de realização desse exame de infeliz nome, há condições de se exercitar o poder de forma democrática e este procedimento defendemos no subitem anterior. A interdisciplinaridade é conduta no caminho da democracia.

\subsubsection{O exame criminológico na jurisprudência}

Quando entrou em vigor a Lei de Execução Penal, em 1984, o parágrafo único do art. 112 estabelecia que decisão sobre progressão de regime de qualquer pena deveria ser precedida, além da constatação do cumprimento de um sexto da pena no regime anterior, "de parecer da Comissão Técnica de Classificação e do exame criminológico, quando necessário”.

Assim, o procedimento básico para a concessão de progressão de regime dependia de constarem nos autos o pedido (ou portaria do juízo, conforme previsão do art. 195 da LEP), cópia do exame criminológico, parecer da CTC e parecer do Ministério Público. Isto quando não era necessário o cálculo de pena, uma eventual retificação da guia de recolhimento (art. 106) ou a solicitação de um ou outro documento extra.

Por enquanto não retornaremos ao assunto exame criminológico. Apenas a dificuldade processual nos interessa no momento. Condenados que já haviam cumprido bem mais de um sexto da pena, às vezes um terço, às vezes metade e até quase a pena completa, tinham ainda que aguardar a juntada aos autos do parecer da CTC e do exame criminológico, mesmo que não tivessem praticado qualquer conduta objetivamente contrária às regras do sistema penitenciário. 
Mais grave é o fato de que diante da precariedade do sistema penitenciário muitos exames criminológicos eram realizados tão somente para efeito de instruir o momento processual de progressão de regime, ou seja, um exame que deve ser inicial, auxiliar do processo individualizador da pena, acaba se tornando tão somente um documento a mais na burocrática execução penal.

Dentro da estrutura da LEP o processo de execução penal só haveria de esperar o parecer da CTC, porque o exame criminológico já deveria ter sido realizado no início da execução (art. $8^{\circ}$ ). O legislador pretendia que após o exame criminológico inicial o preso fosse acompanhado pela CTC e, por ocasião da concessão de progressão de regime, a comissão elaborasse parecer sobre a sua conduta.

Mas exame e parecer acabavam sendo produzidos juntos, sem nenhum sentido, só para cumprir exigência procedimental e satisfazer a letra da lei apenas no que diz respeito à autuação do processo em juízo. Os poucos técnicos e as raras comissões existentes em todo o país se desdobravam para elaborar exames criminológicos e pareceres em série, a toque de caixa, diante da requisição judicial.

O juiz, comodamente, aguardava os exames e pareceres, enquanto o preso não tinha qualquer notícia do andamento do procedimento que poderia aproximá-lo da liberdade. E, para completar, dados do exame criminológico ou do parecer da CTC poderiam ser extraídos a critério do juiz para que a progressão de regime fosse negada.

Crescia a escala de encarceramento. A demora desses documentos transformou-se no funil do sistema penitenciário. Cada dia mais aprisionamento, mais forte a política encarceradora de aumento de penas, enquanto que menor era o investimento em equipes técnicas, escasso o número de psicólogos, assistentes sociais e advogados do sistema. Era matematicamente impossível sustentar uma estrutura originada do ideal de ressocialização, com exames, acompanhamentos e pareceres, dado o nível de encarceramento produzido.

O primeiro Estado a sentir que o sistema começava a fazer água foi São Paulo. O então Secretário de Administração Penitenciária, Nagashi Furukawa, foi um dos articuladores da alteração da LEP, comparecendo ao Congresso Nacional, participando de debates sobre a alteração legislativa e defendendo uma maior objetivação na análise dos procedimentos da 
execução penal ${ }^{179}$. O exame criminológico e o parecer da CTC precisavam ser extintos para desafogar o sistema penitenciário, pois, afinal, não cumpriam mesmo as suas funções.

O mais curioso é que a mesma superlotação carcerária que serviu de argumento para se defender a extinção do exame criminológico serviu, antes, para que se planejassem a realização desse tipo de exame. É o que se depreende do relatório da CPI do sistema penitenciário, de 1976, acima citado. O legislador de 1984, partindo das conclusões dessa comissão, pensou num exame criminológico que viria para amenizar os efeitos dessa superpopulação, organizando e classificando cientificamente os presos.

É de $1^{\circ}$ de dezembro de 2003 a Lei $\mathrm{n}^{\mathrm{o}}$ 10.792, mais uma legislação para o balaio de normas desconexas e contraditórias do nosso ordenamento. Ao mesmo tempo que reformou a redação do art. 112 da LEP para que o exame criminológico e o parecer da CTC não fossem mais requisitos da progressão de regime, com o fim de dinamizar o processo de execução e aliviar a superlotação carcerária, intuito aparentemente humanitário, criava o Regime Disciplinar Diferenciado, resumidamente uma forma de cumprimento da pena privativa de liberdade que faz o sistema penal retroceder mais de cem anos, porque é regime similar ao pensilvânico do final do século XIX. Ou seja, não é lei só incoerente frente ao ordenamento jurídico, é norma legal internamente desarticulada.

Não nos deteremos em abordar o RDD que evidentemente significa o total abandono do discurso ressocializador. No entanto, algumas poucas palavras devem ser ditas, porque pode parecer que ao se afastar o ideal ressocializador estejamos fatalmente tendentes a proceder de forma rigorosa, cega e violenta contra o condenado. Mais uma vez deve ser dito, a ressocialização nasceu como pretexto para se alcançar uma maior humanização do sistema penitenciário e acabou se tornando legitimadora da prisão e, consequentemente, de inúmeras violações. Mas não significa que a exclusão do meio leve consequentemente ao abandono do fim. A dignidade humana deve servir de parâmetro para a atuação do Estado, independentemente de qualquer meio que se utilize.

\footnotetext{
${ }^{179}$ Em pronunciamento no Senado Federal, posteriormente à lei que alterou a LEP, o Senador Romeu Tuma assim declarou: "Há quem afirme que a extinção do exame criminológico ocorreu por influência do Excelentíssimo Ministro Márcio Thomaz Bastos, da Justiça. Mas, seria temerário responsabilizá-lo pelo sucedido, uma vez que diversas outras autoridades, como o secretário Nagashi Furukawa, da Administração Penitenciária (SAP) paulista, também pugnaram abertamente a favor da Lei 10.792” (2005, p 13355).
} 
Abandonar o pensamento ressocializador não pode levar a condutas como esta de se adotar um regime de pena desumano, que, por ser cumprido em penitenciárias federais (parágrafo único do art. 87 da LEP), normalmente afasta o preso do convívio com a família, coloca-o em Estado de clima e cultura diferentes da sua, em celas individuais com direito a apenas duas horas de banho de sol por dia (art. 52, IV, da LEP), com restrições aos meios de comunicação (art. 5 , III, da Lei 10.792/03), ao contato com outros presos e, o que é mais grave, independentemente da condição de ser preso condenado ou provisório e também indiferentemente do fato de ter o preso cometido qualquer fato para ser considerado perigoso, bastando fundadas suspeitas ( $\$ 2^{\circ}$ do art. 52 da LEP).

Mas voltemos ao art. 112 da LEP. Reformado pela Lei 10.792/03, passou a ter a seguinte redação:

A pena privativa de liberdade será executada em forma progressiva com a transferência para regime menos rigoroso, a ser determinada pelo juiz, quando o preso tiver cumprido ao menos um sexto da pena no regime anterior e ostentar bom comportamento carcerário, comprovado pelo diretor do estabelecimento, respeitadas as normas que vedam a progressão.

A ressalva final respeitadas as normas que vedam a progressão fazia sentido para o legislador naquele momento, porque o STF ainda não havia decidido sobre a inconstitucionalidade da vedação de progressão de regime que havia na Lei de Crimes Hediondos, o que, como vimos, só se deu em 2006. Assim, como alguns juízes e tribunais começavam a decidir pela inconstitucionalidade, pensou o legislador que reforçando a proibição iria sanar a falha original da lei ou ao menos intimidar alguns juízes menos convictos do equívoco da pena integralmente em regime fechado.

Passou, então, a progressão de regime a ser subordinada somente a uma declaração de bom comportamento carcerário. A lei é clara, por isso transcrevemos o texto acima, o procedimento para a mudança de regime havia mudado, tornou-se mais objetivo e rápido, porque prescinde da juntada de documentos que, da forma como eram feitos, atrasavam e obstaculizavam a concessão dos regimes mais brandos de cumprimento de pena.

Não obstante, um fenômeno aconteceu. A magistratura tornou-se, de uma hora para outra, zelosa em demasia para com o sistema penitenciário, preocupada com a individualização da pena que deveria ser feita pelo exame criminológico, atenta para o 
instrumento ressocializador e de defesa social que a história legou para o cárcere, e, sem qualquer base legal, continuou achando possível exigir o exame criminológico como requisito para a progressão de regime.

AGRAVO EM EXECUÇÃO (...) MANTIDA A DECISÃO MONOCRÁTICA. Embora não mais exigido o exame criminológico para eventual pedido de progressão de regime, não é vedado ao juiz exigir subsídios para garantir que o apenado não venha a cometer um novo delito após a concessão do benefício, mostrando que ainda não estava pronto para uma nova reintegração social. (TJRS, Ag. $\mathrm{n}^{\mathrm{o}} 70015855596,7^{\mathrm{a}}$ Cam. Crim., Rel. Des. Alfredo Foerster, J. em 05/10/2006).

Ora, no acórdão acima não temos só a crença na ressocialização por meio do cárcere, temos a afirmação de que o julgador acredita poder o exame criminológico ser um prognóstico seguro sobre a futura vida em sociedade do apenado. Frise-se, outrossim, que o exame criminológico nunca teve essa função, pois, como já examinado, ele é um procedimento relacionado à individualização inicial da pena, devendo ser realizado quando do ingresso do apenado no estabelecimento penal. Nem antes da reforma de 2003 era possível conceber um exame criminológico que trouxesse prognóstico neste sentido.

O julgador acredita ser a progressão de regime um benefício concedido pelo Estado. Benefício passa a noção de que o preso está sendo agraciado, ganhando um presente, portanto não pode reclamar se está sendo beneficiado tardiamente e até se não for beneficiado. Não há Estado de Direito na esfera da concessão de benefícios, mas somente um Estado paternal, autoritário, que age exclusivamente calcado na sua soberania.

Outras decisões, umas mais explícitas no sentido da crença ressocializadora, outras nem tanto, seguiram autorizando que os juízes de execução penal continuassem requisitando exames criminológicos para instruir a análise de progressão de regime:

Devemos lembrar que a pena além do caráter punitivo possui a finalidade de ressocialização. O condenado deve demonstrar sua resposta e adaptação ao regime prisional em que se encontra para que possa ser beneficiado com outro mais brando. O juiz da execução penal é livre para formar o seu convencimento e, embora não adstrito somente aos laudos periciais, continua podendo, quando entender necessário, determinar a realização de exame criminológico para avaliar o mérito do condenado

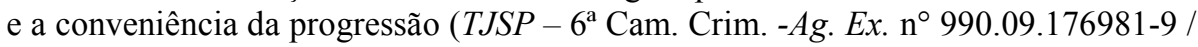
SP - Rel. Des. Marco Antônio Marques da Silva - voto 9392 - v. u. - j. em 24.09.09) ${ }^{180}$.

\footnotetext{
${ }^{180}$ No mesmo sentido, autorizando ou aceitando que o juiz exija exame criminológico para efeito de progressão de regime: TJMG, $5^{\text {a }}$ Cam. Crim., HC 1.0000.07.451429-0/000(1), Des. Rel. Maria Celeste Porto, j. em 24/04/07;
} 
O exame criminológico não foi extinto pela Lei 10.792/03, apenas deixou de existir como requisito da progressão de regime. Continuou previsto como espécie de exame que deveria auxiliar a atividade individualizadora da administração penitenciária, portanto não há como a jurisprudência fazer dele uma perícia capaz de avaliar o mérito do condenado para a progressão de regime.

O desconhecimento do processo de individualização administrativa da pena é indício de que a jurisprudência não está efetivamente preocupada com a ressocialização do apenado, como afirmado nas decisões acima. A exigência do exame criminológico como requisito para a progressão de regime só pode derivar do interesse em se prolongar o tempo de prisão do sentenciado.

Não há outra justificativa. Se o preso não cometeu qualquer fato que indique um comportamento negativo durante o cumprimento da pena, já cumpriu tempo suficiente para pleitear a progressão, por que o juiz exigir um exame que, naquele momento processual não está mais previsto em lei? A única resposta é o interesse, não se sabe originado de qual sentimento, em manter o condenado preso por mais tempo.

Tal conclusão é reforçada pelo fato de que a decisão desconhece completamente a estrutura em que se insere o próprio exame criminológico que ela entende por importante. Já o dissemos, o exame criminológico, antes da reforma da LEP, devia ser juntado ao pedido de progressão de regime para que, comparado com o parecer da CTC, pudesse auxiliar o juiz a avaliar a evolução do comportamento do apenado. Nunca, porém, foi exame que devesse trazer qualquer manifestação sobre o futuro, até porque se parte do binômio delitodelinquente, e na expressão da exposição de motivos da LEP (Item 34), deve ser procedimento

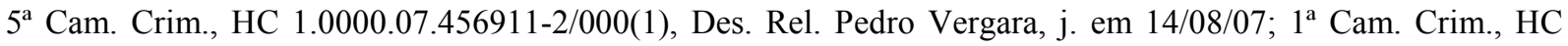
1.0000.07.449738-9/000(1), Des. Rel. Sérgio Braga, j. em 13/02/07; $3^{\text {a }}$ Cam. Crim., HC 1.0000.06.4443971/000(1), Des. Rel. Jane Silva, j. em 30/10/06 - TJDFT, $1^{\text {a }}$ Turma, Ag. 20090020050286RAG, Rel. Sandra de Santis, j. em 14/05/09; HC 20060020129547, Rel. Lecir Manoel da Luz, j. em 30/11/2006; $2^{\text {a }}$ Turma, Ag. 20070020030269, Rel. Getúlio Pinheiro, j. em 10/05/07 - TJRJ, $3^{\text {a }}$ Cam. Crim., Ag. no 1640/2008, Rel. Des. Valmir de Oliveira Silva, j. em 09/12/03; $1^{\text {a }}$ Cam. Crim., HC 02831/2007, Rel. Des. Marcus Basílio, j. em

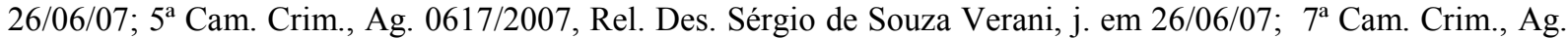

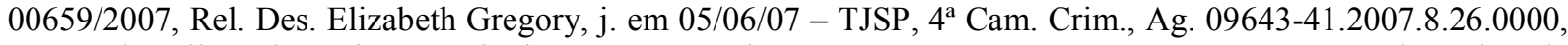

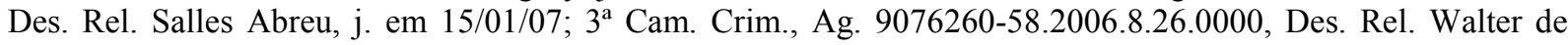
Almeida Guilherme, j. em 17/04/07; $3^{\text {a }}$ Cam. Crim., HC 030638-75.2007.8.26.0000, Des. Rel. Luiz Pantaleão, j. em 02/12/07; $9^{\text {a }}$ Cam. Crim., Ag. 9232376-58.2007.8.26.0000, Des. Rel. Penteado Navarro, j. em 21/11/07; $8^{\text {a }}$ Cam. Crim., HC 0103275-24.2007.8.26.0000, Des. Rel. Poças Leitão, j. em 26/02/08; $11^{\mathrm{a}}$ Cam. Crim., Ag. 9174159-85.2000.8.26.0000, Des. Rel. Antônio Mansur, j. em 30/04/08. 
direcionado para o passado, tempo onde está o delito e onde se desenvolveu a conduta tida por criminosa.

De nada serve um exame criminológico realizado somente para instruir um pedido de progressão de regime, dissociado da atividade diária do sistema penitenciário ${ }^{181}$. Mas o que mais impressiona é a inclusão de requisito para a progressão de regime que não está previsto em lei.

Uma lei revogada é uma lei inexistente. No caso, é como se nunca tivesse havido a previsão de parecer da CTC e de exame criminológico para efeito de progressão de regime. A lei que previa tais condutas técnicas não se encontra mais no mundo jurídico, virou peça dos arquivos do legislativo. Não há como o juiz exigir, para a concessão de direito do apenado, notadamente relacionado ao seu bem mais sagrado que é a liberdade, documento que, além de não estar previsto em lei, só irá retardar ou obstaculizar essa concessão de direito.

O verdadeiro exame criminológico, o que poderia beneficiar o apenado de alguma forma, porque lhe proporcionaria uma separação e lotação mais adequada no estabelecimento penal, um exame que pudesse indicar suas atividades laborais e de descanso na penitenciária, suas assistências, desde o início da pena, este exame, que está na lei (art. $8^{\circ}$ da LEP), os juízes não exigem que seja feito. Pelo contrário, quando há um procedimento que pode aproximar o preso da liberdade, os tribunais passam estranhamente a serem zelosos para com a ressocialização do apenado, exigindo exame que não está previsto em lei e que o manterá no cárcere no mínimo por mais alguns meses.

Veja-se que nada impede que o juiz solicite cópia do exame criminológico. Cópia, pois o exame, pela lei, já deveria ter sido feito e já deveria constar do prontuário do preso como instrumento individualizador da pena. Tal medida poderia ser tomada e, se tomada no início do cumprimento da pena, melhor, pois forçaria a administração a realizar exame que é de sua obrigação. O que não é cabível é, uma vez instaurado procedimento de progressão de regime,

\footnotetext{
${ }^{181}$ Da Exposição de Motivos da LEP, “reduz-se-á a mera falácia o princípio da individualização da pena, com todas as proclamações otimistas sobre a recuperação social, se não for efetuado o exame de personalidade no início da execução, como fator determinante do tipo de tratamento penal, e se não forem registradas as mutações de comportamento ocorridas no itinerário da execução" (Item 27).
} 
o judiciário passe de repente a se preocupar com o processo individualizador da pena e exija exame extemporâneo, o que irá atrasar direito do preso à liberdade.

As decisões colacionadas acima foram proferidas por tribunais estaduais, mas, como era de se esperar, logo a matéria foi objeto de exame das cortes superiores. STJ ${ }^{182}$ e STF $\operatorname{logo}$ firmaram o entendimento de que o juiz poderia continuar solicitando o exame criminológico como requisito na execução da pena.

CRIME HEDIONDO OU DELITO A ESTE EQUIPARADO - IMPOSIÇÃO DE REGIME INTEGRALMENTE FECHADO -INCONSTITUCIONALIDADE DO $\S$ $1^{\circ}$ DO ART. $2^{\circ}$ DA LEI No $8.072 / 90$ - PROGRESSÃO DE REGIME ADMISSIBILIDADE - Exigência, contudo de prévio controle dos demais requisitos, objetivos e subjetivos, a ser exercido pelo juízo de execução (...) A realização de exame criminológico - importância do mencionado exame na aferição da personalidade e do grau de periculosidade do sentenciado (RT 613/278) - Edição da Lei $\mathrm{n}^{\circ} 10.792 / 2003$, que deu nova redação ao art. 112 da LEP - diploma legislativo que, embora omitindo qualquer referência ao exame criminológico, não lhe veda a realização, sempre que julgada necessária pelo magistrado competente - consequente legitimidade jurídica da adoção, pelo Poder Judiciário, do exame criminológico... (STF, HC 85963 ED/SP, Rel. Min. Celso de Melo, j. em 03/10/2006).

O Ministro Celso de Melo, o mesmo que foi contrário à consideração de inconstitucionalidade da vedação de progressão de regime, alegando ser necessário estabelecesse o Estado "mecanismos diferenciados de repressão à criminalidade violenta" (voto proferido no HC 82.959-7/SP, fls. 690, já referido - Grifo no original), não havendo mais obstáculo à progressão de regime, encontrou um novo mecanismo diferenciado para a repressão à criminalidade: o exame criminológico.

Não há outra justificativa para o judiciário criar condição ao direito do apenado onde a lei não cria. Combater a criminalidade com o exemplo, com a imolação de um condenado que deverá cumprir sua pena de forma mais grave do que o previsto em lei, por culpa da criminalidade existente nas ruas e da qual ele fez parte um dia, é a única explicação encontrada para que haja a ressurreição do exame criminológico.

Ressalte-se que, até o momento, não nos posicionamos sobre a importância do exame criminológico e do parecer da CTC para efeito de progressão de regime, como disciplinado

182 “...Contudo, a realização do referido exame pode perfeitamente ser solicitado, quando as peculiaridades da causa assim o recomendarem, atendendo-se ao princípio da individualização da pena, previsto no art. $5^{\circ}$, inciso XLVI, da Constituição Federal, como aconteceu na hipótese em apreço, em que se exigiu a realização da perícia com fundamento na periculosidade do ora paciente, devidamente comprovada nos autos..." (STJ, HC 99.057/SP, Rel. Ministra LAURITA VAZ, QUINTA TURMA, j. em 08/04/2008). 
originariamente na LEP. O que vem ao caso é a exigência de requisito que viola objetivamente o princípio da legalidade penal.

Se o princípio da legalidade indica que a pena aplicada e executada deve ser clara, compreensível, estritamente vinculada às disposições legais, o posicionamento dos tribunais seguem no sentido oposto, fazendo da pena algo manipulável, abstrato e em prejuízo ao condenado. Além de tornar o procedimento para a concessão de progressão de regime mais complexo, criam, os tribunais, a possibilidade de o magistrado indeferir direito com base em um juízo de periculosidade que não existe na lei penal. Periculosidade que, ademais, é conceito de "conhecida inconsistência científica, inidôneo para ser utilizado em um processo justo" $" 183$ (BARATTA, 2006, p. 385).

Do texto da lei sabemos que periculosidade é característica do inimputável a ser avaliada em procedimento próprio (art. 175 e segts. da LEP) e não do criminoso comum, por mais grave que tenha sido o crime praticado. Se há criminosos que foram considerados perigosos, a violência de suas condutas deve estar devidamente compreendida na pena aplicada, e qualquer consideração extra dessa perigosidade constitui-se evidentemente em um bis in idem.

O Direito Penal hodierno é Direito Penal do fato e não Direito Penal do autor, pois este sempre esteve relacionado com regimes totalitários e deriva das construções dos positivistas mais antigos, remontando mesmo ao seu precursor Cesare Lombroso (PASCHOAL, 2003).

Voltando uma vez mais na história, apenas para demonstrar o quão sem propósito é a ideia de se condicionar direito do preso a exame que supostamente iria avaliar o seu grau de periculosidade, nem quando tal conduta era viável dentro do ordenamento jurídico, sob a égide da antiga parte geral do Código Penal, de 1940, a crença em tal procedimento prosperava. Nelson Hungria, um dos membros da comissão revisora daquele código, mesmo assumindo certo grau de influência positivista, dizia que a "indeterminação da pena, do ponto de vista político, seria desaconselhável, porque enseja um demasiado arbítrio judicial, dada a atual precariedade ou relativa insegurança dos indícios psicológicos da cessação de antisociabilidade" (1973, p. 35).

\footnotetext{
${ }^{183}$ Tradução livre de: "conocida la inconsistencia científica que lo hace inidóneo para ser utilizado en un proceso justo" (BARATTA, 2006, p. 385).
} 
Lamentavelmente, o "fenômeno criminal que se traduz na crítica do 'feio', do 'mau', do 'anormal', do 'louco', do 'primitivo', ainda hoje voz corrente no pensamento jurídico nacional em muitas questões de direito criminal" (SHECAIRA, 2008, p. 136), continua justificando posicionamentos judiciais afastados da realidade punitiva, os quais, fantasiosamente (ou maldosamente), acreditam que "parâmetros criminológicos podem ser referência dogmática para a atuação perante os tribunais, ou mesmo para o desenvolvimento das ideias doutrinárias mais recentes. É essa superação que ainda está a se exigir dos operadores do direito" (Idem, Ibidem).

Assim, quanto mais foi se firmando o posicionamento do STF, mais escassas foram sendo as decisões que garantiam objetivamente ao apenado a progressão de regime com base no cumprimento de período de pena e segundo o bom comportamento certificado pela direção, na forma da redação do art. 112 da $\mathrm{LEP}^{184}$. O STF reiteradamente passou a decidir no sentido de ser exigível o exame criminológico, ainda que totalmente dissociado de sua verdadeira função de individualização da pena:

HABEAS CORPUS. AGRAVO EM EXECUÇÃO: DEVOLUTIVIDADE. ELABORAÇÃO DE EXAME CRIMINOLÓGICO PARA FINS DE PROGRESSÃO: POSSIBILIDADE, MESMO COM A SUPERVENIÊNCIA DA LEI N. 10.792/03. (...) 2. Conforme entendimento firmado neste Supremo Tribunal, a superveniência da Lei n. 10.792/2003 não dispensou, mas apenas tornou facultativa a realização de exames criminológicos, que se realiza para a aferição da personalidade e do grau de periculosidade do sentenciado (v.g., Habeas Corpus n. 85.963, Rel. Ministro Celso de Mello, DJ 27.10.2006). 3. As avaliações psicossociais estão compreendidas no gênero "exame criminológico" e podem servir de subsídio técnico para a formação da livre convicção do magistrado. 4. Ao analisar os requisitos de ordem subjetiva, o Tribunal ad quem pode se amparar - de acordo com a sua livre convicção - em laudos psicossociais elaborados em atendimento à requisição do Juízo das Execuções, e a par dos quais a decisão recorrida foi prolatada (Código de Processo Penal, art. 157 e 182). (...) 6. Na linha dos precedentes deste Supremo Tribunal posteriores à Lei n. 10.792/03, o exame criminológico, embora facultativo, deve ser feito por decisão devidamente fundamentada, com a indicação dos motivos pelos quais, considerando-se as circunstâncias do caso concreto, ele seria necessário. 7. Ordem concedida para restabelecer a decisão proferida pelo Juízo das Execuções (STF, $1^{a}$ Turma, HC 94503, Rel. Min. Cármem Lúcia, j. em 28/10/2008).

\footnotetext{
${ }^{184}$ Neste sentido: "PENAL E PROCESSUAL PENAL. RECURSO DE AGRAVO. EXECUÇÃO PENAL. PROGRESSÃO DE REGIME CONCEDIDA. NOVA REDAÇÃO DO ARTIGO 112 DA LEP. REQUISITOS SATISFEITOS. RECURSO IMPROVIDO. 1. Em virtude da alteração promovida pela Lei 10.792/2003, a progressão de regime de cumprimento de pena conta com dois requisitos. O primeiro, de caráter objetivo, referese ao cumprimento de pelo menos 1/6 (um sexto) da pena; o segundo, de viés subjetivo, concerne ao bom comportamento carcerário, o qual deve ser atestado pelo diretor do estabelecimento prisional. 2. Destarte, não mais se exige a realização do exame criminológico. 3. Recurso conhecido e improvido. Decisão vergastada mantida"(TJDFT, $2^{\text {a }}$ T. Crim., Ag. 20060110255053, Rel. Nilson de Freitas Custódio, j. em 14/12/2006).
} 
Embora a Exposição de Motivos da LEP diga que o exame criminológico é espécie do gênero exame da personalidade (Item 34), a Ministra Cármem Lúcia afirma, como relatora do acórdão acima, que as avaliações psicossociais estão compreendidas no gênero "exame criminológico”. A confusão entre espécie e gênero é justificável, a lei não especificou no que consistia o exame criminológico. Apesar da intenção do legislador, expressa na exposição de motivos, não há como conceituar de forma clara o exame criminológico. Certo que inúmeros autores conceituam o exame criminológico, mas o que nos interessa é a conceituação legal e não a médica ou psicológica.

Por isso, há que se repisar a advertência: em um Direito Penal subordinado ao princípio da legalidade, dentro de um Estado Democrático de Direito, não há como a liberdade de um cidadão, seja ele violento, doente, pobre, rico ou analfabeto, ficar subordinada a um exame que a lei não conceitua, que o judiciário não entende e que é ainda mais estranho e surreal para o preso.

Estivemos repetindo neste trabalho a característica de diálogo que deveria nortear o Direito. A Exposição de Motivos da LEP também faz referência à lei como instrumento de diálogo (Item 38). Assim, nenhum diálogo será possível se a prática judicial for direcionada sinicamente para a repressão criminal, considerando o sentenciado um anormal merecedor de medida terapêutica na qual nem mesmo o judiciário deposita confiança.

Os presos, perplexos, sofrem com a dúvida que se semeia no meio penitenciário, sentem medo da investigação de seus comportamentos que poderá distanciá-los da liberdade, “muitos expressam que é mais difícil encarar os procedimentos de avaliação, do que as más condições e os maus tratos da prisão. Como decorrência, surge a certeza de estarem submetidos a um processo carregado de obscuridades" (WOLFF, 2005, p. 164).

Não raro pessoas que praticam um fato típico e evidentemente demonstram periculosidade a indicar a aplicação de medida de segurança são condenados a penas privativas de liberdade, indício de que o judiciário não crê sequer no tratamento que verdadeiramente a lei prescreve ${ }^{185}$. No caso, o tratamento do preso comum, permeado

\footnotetext{
${ }^{185}$ Seguindo orientação do STF (HC 70.386, Rel. Min. Celso de Melo, j em 31/05/94), a dispensa do laudo de insanidade mental quando solicitado pela defesa é comum na prática judicial, ficando a inimputabilidade do réu
} 
obtusamente pelo exame criminológico, como tem proclamado o STF, nada tem de tratamento, mas sim de acréscimo de punição.

O "fetichismo do exame criminológico" é, com certeza, "decorrência natural do fenômeno da medicalização do crime" (SHIMIZU, 2011, p. 198) e o breve histórico acima comprova isso, mas sua manutenção nos dias de hoje como instrumento corretivo não pode derivar de um crédito renovado nas ciências humanas ou médicas do século XXI. Não é crível que magistrados, promotores e advogados tenham verdadeiramente fé que o exame criminológico possa lhes trazer indícios seguros sobre o comportamento de quem quer que seja. O interesse é punitivo, nada mais. Puro exercício de poder sobre o condenado, que deixa de ser visto como sujeito de direitos.

As tatuagens, os narizes tortos, as orelhas, as cicatrizes e as características cranianas seriam fundamentos ridículos, para não dizer criminosos, para o acréscimo de punição de um ser humano hoje, mas os juízes, sedentos por mais características que possam aumentar a furor punitivo, as vão procurar no psíquico. O vínculo do exame criminológico com a escola positiva está mais vivo do que nunca, o que mudou são os tipos de cicatrizes que se buscam.

A cisão que há entre a esfera do processo penal e da execução penal em termos de consideração do réu ou condenado como sujeito de direitos é evidente inclusive na própria Exposição de Motivos da LEP, quando afirma que "em homenagem ao princípio da presunção de inocência, o exame criminológico, pelas suas peculiaridades de investigação, somente é admissível após declarada a culpa ou a periculosidade do sujeito" (Item 30) ${ }^{186}$.

Como dito antes, a sentença criminal passou a ser o divisor de águas. Ora, a única circunstância diferente entre um cidadão que cometeu um delito e outro que não cometeu é o próprio delito praticado, e do qual já resultou uma sanção legalmente prevista em lei, portanto, no mais, o cidadão condenado é também presumidamente inocente. O futuro deste cidadão condenado não pode igualmente ser investigado, porque somente o seu passado não é mais presumidamente inocente.

subordinada à existência de dúvida do magistrado, em evidente julgamento antecipado direcionado à aplicação da pena.

${ }^{186}$ No mesmo sentido, Sérgio Salomão Shecaira: "Não obstante, o princípio constitucional de inocência impede na nossa maneira de ver - a realização do informe criminológico de um processado" (2010, p. 29). 
Reforçando a jurisprudência e utilizando-se de recurso extremamente discutível ${ }^{187}$, notadamente em matéria criminal, onde a criação ou agravamento de pena só pode se originar da elaboração legislativa, o STF editou a Súmula Vinculante $n^{\circ} 30$, com o seguinte teor:

Para efeito de progressão de regime no cumprimento da pena por crime hediondo, ou equiparado, o juízo da execução observará a inconstitucionalidade do art. $2^{\circ}$ da Lei 8.072 , de 25 de julho de 1990, sem prejuízo de avaliar se o condenado preenche, ou não, os requisitos objetivos e subjetivos do benefício, podendo determinar, para tal fim, de modo fundamentado, a realização de exame criminológico (Publicação 26/02/10).

Não obstante a lei que definitivamente permitiu a progressão de regime aos crimes considerados hediondos, reformando o $\S 1^{\circ}$ da Lei 8.072/90 (Lei 11.464/07), havia decisões que continuavam negando a progressão nesses casos, com o intolerável argumento de que a Lei 11.464/07 não se aplicaria aos fatos anteriores. Por isso o STF, para dirimir qualquer dúvida, emitiu a súmula acima, mas, não desavisadamente, acabou criando a possibilidade de execução de pena mais grave do que a prevista em lei.

Paradoxalmente, o princípio da legalidade, que faz a Lei 11.464/07 retroagir, por ser evidentemente benéfica ao condenado, prevendo pena a ser cumprida de forma menos grave, com direito à progressão de regime; no contexto da edição de uma única súmula, o STF resolveu desconsiderar o mesmo princípio da legalidade, permitindo que a execução da pena seja feita de forma mais grave, com a exigência de exame criminológico, sem previsão legal.

Diz-se que o STF assim procedeu não desavisadamente porque no voto do ministro Marco Aurélio, contrário à súmula em questão, tal advertência ficou bem clara:

podemos partir para a interpretação analógica que acabe por prejudicar o réu? A resposta é desenganadamente negativa. Não podemos nos antecipar a projeto em tramitação no Congresso, para restabelecer - no campo jurisprudencial - o exame criminológico, que, sabidamente, dificulta a progressão (...) Por isso é que adiantando o voto, e devo ter muito cuidado na edição de verbete vinculante especialmente em matéria penal, no sentido de não aprová-lo, porque se o fizermos, restabelecendo a redação primitiva do art. 112 da Lei de Execução Penal, estaremos atuando como legisladores (fls. 05).

187 Sérgio Sérvulo da Cunha sustenta que a súmula vinculante "ofende direitos e garantias fundamentais consagrados no art. $5^{\circ}$ (incisos, II, XXXV, LV) da CF 88; agride princípios extra-dogmáticos de hermenêutica; representa inadmissível retorno a práticas autoritárias há muito superadas na história do Direito; usurpa competência das instâncias ordinárias. Ao editar súmula vinculante o STF estará criando norma (exercício de competência legislativa) que o Congresso, querendo, só poderá alterar mediante emenda constitucional" (2005, p. 660) 
Com efeito, está em tramitação no Congresso Nacional, de autoria da senadora Maria do Carmo Alves, projeto de lei, sob o número 190/07, visando restabelecer a exigência de exame criminológico para efeito de progressão de regime. No início o referido projeto apenas restabelecia a redação original do art. 112 da LEP, recolocando o exame criminológico e o parecer da CTC como requisitos para a progressão, mas, posteriormente, recebeu emenda, ainda na Comissão de Constituição e Justiça do Senado, para que o exame e o parecer fossem exigidos somente em casos de crimes considerados hediondos ${ }^{188}$, seguindo a mesma orientação da súmula vinculante.

Antes o projeto de lei mantivesse a redação original, porque ao menos zelaria pela manutenção de um ordenamento jurídico construído como um todo. A reforma penal de 1984, apesar de ter trazido princípios de tratamento incompatíveis com a consideração do apenado como cidadão, tem coerência. A alteração que se pretende agora, como feito na súmula vinculante, pontual, não restaura o sistema anterior e distorce o atual.

Aliás, toda essa discussão sobre se cabe ou não exame criminológico ou parecer da CTC para que se avalie direito à progressão de regime tem causado uma grande deturpação do ordenamento jurídico, com decisões exigindo manifestação da CTC onde antes, na redação original da LEP, não era cabível. Temos exemplos de decisões que passaram a exigir exame criminológico como requisito para avaliar direito à saída temporária do art. 122 da LEP (TJMG, HC 1.0000.07.457547-3/000(1), Des. Rel. Vieira de Brito, j. 07/08/07), para compor pedido de comutação (TJSP, 5 a Cam. Crim., Ag. 0408460-62.2010.8.26.0000, Rel. Des. Sérgio Ribas, j. em 03/03/11) ou para instruir procedimento de livramento condicional (TJRJ, $7^{\mathrm{a}}$ Cam. Crim, HC 0039681-94.2008.8.19.0000 (2008.059.07667), Des. Rel. Alexandre H. Varella, j. 25/11/08).

Quanto ao livramento condicional, o fundamento para se exigir manifestação da CTC estava no art. 83, parágrafo único do Código Penal, dispondo que nos casos de crimes dolosos, cometidos "com violência ou grave ameaça à pessoa, a concessão do livramento ficará

\footnotetext{
${ }^{188}$ Disponível em: <www.senado.gov.br>. Acesso em 5 março 2011. Na redação da última emenda que recebeu o projeto, o parágrafo único do art. 112 da LEP teria o seguinte teor: "A decisão sobre progressão de regime, livramento condicional, indulto e comutação de pena será motivada e precedida de parecer da Comissão Técnica de Classificação e do Ministério Público e, ainda, do exame criminológico, quando a condenação houver sido pela prática de crime hediondo, ou a ele equiparado, ou cometido mediante violência ou grave ameaça e no caso de reincidência"
} 
também subordinada à constatação de condições pessoais que façam presumir que o liberado não voltará a delinquir", norma originada da reforma de 1984; tal norma deveria ter sido considerada derrogada com a nova redação do art. 112 da LEP. Todavia, a jurisprudência não só tem mantido a exigência que o legislador pretendeu acabar, como a tem ampliado indistintamente.

Voltando à súmula do STF, esta traz consequências mais prejudiciais, vez que além de permitir tratamento diferenciado, não previsto em lei, entre o apenado que cometeu crime hediondo e o que cometeu crime comum, permite também o tratamento diferenciado entre sentenciados que cometeram crimes da mesma espécie. Ao colocar a exigência sob o critério do juiz, abre-se espaço para os apenados que cometeram o mesmo tipo de crime, o hediondo ou assemelhado, terem tratamento diverso na execução da pena.

Ressalte-se que o dito anteriormente sobre o cumprimento de dois quintos de pena para a progressão de crimes hediondos também vale para essa nova exigência, ou possibilidade de exigência, no caso da súmula vinculante. Viola o princípio da isonomia inscrito no art. $5^{\circ}$, XLVIII, da CF, o fato de se pretender que apenados com penas distintas em termos de direitos e em nível de gravidade tenham suas sanções executadas no mesmo estabelecimento penal.

\subsubsection{Requisito subjetivo e princípio da legalidade penal}

Ressaltamos a importância do trabalho interdisciplinar da CTC, depois defendemos que o exame criminológico, apesar de sua origem médico positivista, possa e deva ser visto sob outro prisma, como verdadeiro orientador da administração penitenciária, amenizando os efeitos da exclusiva preocupação com a segurança.

O escorço histórico acima empreendido foi no sentido de fazer ver que o exame criminológico pode e deve ser considerado outra coisa, que não mais o estudo do ser humano criminoso, como um doente anormal. O século XXI é capaz de nos permitir este pequeno avanço.

Em seguida trouxemos a jurisprudência que vê o exame criminológico como antes, como perícia de estudo do homem e seu comportamento, como fonte científica auxiliar para a 
negação de direitos que poderiam ser concedidos de forma objetiva, tudo em nome de um tratamento ressocializador que evidencia ser a máscara do intento verdadeiro de sancionar.

Contudo, nem a jurisprudência nem a súmula vinculante nem o projeto de lei, ainda que este realmente venha a se tornar lei, podem afastar o que foi dito até agora sobre a possibilidade de se ver o exame criminológico como momento de interdisciplinaridade, como orientador da administração, em benefício do convívio no cárcere e em favor da sobrevivência dos milhares de presos.

Deve ficar clara a diferença entre os dois campos de atuação: a atividade da CTC junto à execução penal administrativa, a ser o local do exercício da interdisciplinaridade e, consequentemente, da prática democrática; e a atividade da CTC de entrega para o Poder Judiciário de exames e pareceres que devem instruir os procedimentos de execução penal.

Falando do segundo tipo de atividade, o exame criminológico, e qualquer parecer técnico que venha a compor o processo de execução, deve ser visto dentro de parâmetros condizentes com o Estado Democrático de Direito e com o princípio da legalidade, que veio para limitar o arbítrio do Estado.

Assim, se o legislador, do congresso ou dos tribunais, diz que há a possibilidade de se exigir o exame criminológico para a avaliação do direito à progressão do apenado, só uma interpretação é compatível com o princípio da legalidade, a interpretação que leve em consideração o exame criminológico como reforço do próprio direito do apenado. Explicando melhor, havendo no estabelecimento penal um fato concreto, uma falta disciplinar grave que possa indicar a negação da progressão de regime àquele apenado, o exame criminológico, ou mais corretamente o parecer da CTC, viria para afastar esse empecilho. No caso, o parecer técnico poderia vir para indicar que a falta disciplinar não deveria ser considerada ausência de mérito para a progressão de regime.

O uso do exame criminológico, ou o parecer da CTC, que defendemos é semelhante à interpretação em bonam partem da lei penal, corolário direto do princípio da legalidade. Sabese que nenhuma norma legal que cria, aumenta ou agrava pena pode ser indeterminada, a fim de se evitar o arbítrio do Estado sobre o cidadão. Assim, quando há uma norma com um grau maior de abstração, ou esta lei é inconstitucional por ferir o princípio da legalidade, ou a única 
interpretação que se poderá fazer será em favor do cidadão. Sim, porque a interpretação in malam partem, utilizando a abstração da lei para agravar a situação do réu ou condenado, equivale à criação ou ao agravamento de pena sem lei, o que é inadmissível.

O mesmo se aplica trazendo a manifestação da CTC para a área processual, como muitos a querem ver, como uma prova pericial a ser requisitada pelo juiz, na forma do art. $196, \S 2^{\circ}$, da LEP. Derivado igualmente do princípio da legalidade é o brocardo in dubio pro reo, que significa não poder o julgador, na dúvida, utilizar qualquer indício contra o réu. Partindo do pressuposto de que o condenado, nos procedimentos em sede de execução, é réu, pois não pode ser punido novamente por fato anterior já julgado, qualquer análise de conduta sem a comprovação cabal de um fato em sentido contrário, deve indicar uma valoração favorável.

Nem se diga que em execução penal vigora o brocardo in dubio pro societate, porque este não pode ser extraído de nenhum princípio constitucional e muito menos de qualquer regra de lei ordinária (NETO, 2009). Não se pode conceber igualmente uma sociedade em que se desrespeitem os direitos previstos e que são a base de sua própria constituição. Aforismo incerto e ambíguo, o in dúbio pro societate, é “inteiramente inaplicável, porque não se pode contrapor o genérico direito da Sociedade a expresso direito individual de qualquer membro componente dessa mesma sociedade" (SILVA, 2001) ${ }^{189}$. Há muito já se percebeu que a construção iluminista de uma sociedade como ente concreto e objetivo deve ser superada ${ }^{190}$, até mesmo para o bem de se caminhar no sentido do respeito à pluralidade e à diversidade que se verifica no seu interior.

Se o Estado não pode interpretar a lei em prejuízo do cidadão, a manifestação da CTC, elemento constitutivo desta lei, mas que, como pronunciamento técnico, também prescinde de interpretação, nunca poderia ser interpretada para agravar a pena do cidadão preso. $\mathrm{O}$

\footnotetext{
${ }^{189}$ No mesmo sentido, Sérgio Marcos de Moraes Pitombo: "É fácil, na sequência, perceber que a expressão in dúbio pro societate não exibe o menor sentido técnico. Em tema de direito probatório, afirmar-se: 'na dúvida, em favor da sociedade' consiste em absurdo lógico-jurídico" (2001-b, p. 8).

${ }^{190}$ Cayley lembra que hoje, inclusive no campo político, "pensadores com pontos de vista diversos como Margart Thatcher e Jean Baudrillard concordam sobre o fim da sociedade em seu conceito moderno. Baudrillard fala da 'morte do social'; Thatcher declara em suas memórias que 'não há mais algo conhecido como sociedade"' (1998, p. 162). (Tradução livre de: "Today, thinkers as diverse as Margaret Thatcher and Jean Baudrillard concur in proclaiming the end of society in this modern sense. Baudrillard speakes of 'th death of the social'; Thatcher states in her memoirs that "there is no such thing as society").
} 
resultado deste esforço de adequar a manifestação da CTC ao Estado Democrático de Direito, onde o princípio da legalidade penal tem enorme valor, é que não há como o sentenciado ter direito negado ou ter sua pena cumprida de forma mais grave em virtude de interpretação de parecer, perícia, laudo ou exame.

Já que a súmula vinculante, com valor de lei, permite que o juiz traga ao processo dados a serem interpretados, estes novos elementos dos autos podem servir para uma avaliação positiva do comportamento do preso, ainda que haja fatos concretos que objetivamente possam impedir o direito à progressão de regime. Em termos práticos, uma falta grave poderia ser rechaçada como indício de conduta negativa, apesar da certidão da administração penitenciária, se a manifestação técnica trouxesse, por exemplo, elementos que indicassem ser tal fato algo esporádico ou involuntário na vida daquele preso, de acordo com as circunstâncias do cárcere. Por outro lado, em nome do princípio da legalidade, um preso que não cometeu qualquer infração disciplinar e possui atestado de bom comportamento, não pode ter direito negado com base na interpretação de características extraídas de sua avaliação psicológica.

Quanto ao atestado de conduta do preso, a ser emitido pela direção, se quisermos uma execução penal realmente consciente da incapacidade de ressocialização no cárcere, dentro do princípio da legalidade, este atestado ou certidão nunca poderá noticiar comportamento negativo se não houver o cometimento de alguma falta grave devidamente apurada, observado o contraditório e a ampla defesa garantidos constitucionalmente. Se é inadmissível que a liberdade de um ser humano fique condicionada às considerações incertas de um laudo, muito menos deve estar subordinada ao bom humor do carcereiro chefe.

\footnotetext{
Se se passa a prescindir da avaliação técnica, certamente por carecer ela não raras vezes de melhor qualidade técnica, por que não se prescindir também do atestado de boa conduta, já que quase nada ele significa em termos de garantia de condições satisfatórias do apenado para a obtenção de benefícios? Isto, quando esse atestado, como foi dito acima, não significa exatamente o oposto, isto é, uma boa identificação com a vida delinqüente (SÁ, 2000, p. 3)
}

Com efeito, não há que se buscar garantias sobre o comportamento do ser humano, visto que estas, independentemente de onde vierem, sempre trarão grau de incerteza incompatível com o princípio da legalidade. O atestado de conduta do preso só deve trazer fatos devidamente comprovados. Esta, aliás, devia ser uma conclusão óbvia do ordenamento 
penitenciário, pois se a regressão de regime só pode se dar com base na evidência do cometimento de uma falta grave ou de um crime (art. 118 da LEP), a progressão de regime também não poderia ser obstaculizada em nenhuma outra situação.

Dizendo de outro modo, se para a lei é indiferente o comportamento para efeito da manutenção de um apenado no regime semiaberto, indicando que este só regredirá para o regime fechado se cometer crime ou falta grave, não há como impedir que um preso progrida do regime fechado para o semiaberto se este igualmente possuir comportamento isento da prática dessas condutas.

É certo que se pode atribuir falhas, e muitas, às apurações de faltas disciplinares e de crimes dentro dos estabelecimentos penais. Mas tais deficiências são muitas vezes potencializadas pela desnecessidade de apurá-las. Ora, se o diretor do estabelecimento penal pode emitir um atestado de conduta negativa sem fundamentá-lo, a fim de agravar a pena de um cidadão, não haverá interesse em apurar de fato as condutas no interior do cárcere e tudo ficará dependendo do juízo a ser feito pelo diretor.

Em suma, em um sistema penitenciário baseado na mais estrita legalidade não poderia haver punição ou pena a ser cumprida de forma mais grave sem um crime ou uma falta grave correspondente $^{191}$. O princípio nulla poena sine lege deve alcançar a esfera penitenciária para se tornar um verdadeiro princípio nulla poena sine lege, nulla poena sine praevia actione.

\subsubsection{O poder geral de cautela na execução penal}

Uma última questão jurídica sobre os procedimentos de execução penal deve ser abordada, pois diretamente ligada à ineficácia do sistema e de grande consequências para os presos. Trata-se da possibilidade de o juiz da execução conceder os direitos dos presos cautelarmente, independentemente da chegada aos autos de exames ou manifestações da administração penitenciária.

\footnotetext{
${ }^{191}$ Para Salo de Carvalho nem a falta disciplinar poderia causar um agravamento da pena no campo judicial e deveria limitar-se ao âmbito administrativo, aos "direitos 'domésticos' do apenado, sob pena de produzir, como ocorre na atualidade, penalidades múltiplas (nas esferas administrativa e judicial), em clara ofensa à máxima ne bis in idem" (2008, p. 197).
} 
Como estamos falando de exame criminológico e de sua exigência em momento processual inoportuno, achamos importante incluir o presente subitem neste momento, pois é diretamente relacionado a uma das atitudes que o magistrado da execução penal pode tomar quando observa o retardo injustificável de direitos do apenado.

Sabe-se que o poder geral de cautela do magistrado é mais elaborado no campo do direito processual civil e que, em matéria penal, somos muito mais fartos de medidas cautelares contra o cidadão, justificadas em nome da tão proclamada defesa social, do que em prol da liberdade. Desde as prisões cautelares, às buscas e apreensões, passando pelas interceptações telefônicas e pelas medidas inominadas da Lei 11.340/06, o sistema penal é rico de ações restritivas de direitos que reforçam a natureza policialesca do poder público, preocupado este mais com a ordem aparente do que verdadeiramente com o cumprimento da Constituição ou das leis, desrespeitadas principalmente por ele próprio.

A doutrina faz derivar o poder geral de cautela do juiz, do inciso XXXV do art. $5^{\circ}$ da Constituição Federal (a lei não excluirá da apreciação do Poder Judiciário lesão ou ameaça a direito), devendo o Judiciário agir para preservar a tutela jurisdicional ameaçada. "A atividade geral cautelar é parte elementar e indissociável da função jurisdicional” (BARROS, 2011), porque diversas situações práticas não podem ficar à mercê da ausência de previsão legislativa, notadamente quando se trata de garantia de direitos fundamentais.

Realmente, diante da impossibilidade prática de a lei prever todas as hipóteses de risco, não faria sentido que o juiz, identificando concretamente um dano à ordem jurídica não prevista pelo legislador, se visse impossibilitado de adotar outras soluções de garantia. Tal postura que, inclusive, ignoraria o conceito de jurisdição como poder, resultaria para o autor numa "vitória de Pirro", na qual se conferem "ao vencedor as batatas" (Rogério Pacheco Alves apud BARROS, 2011).

Pois bem, não há risco maior para a vida de um cidadão do que a perda de sua liberdade, principalmente quando dentro de um sistema cruel e abarrotado de abusos de variadas ordens. O periculum in mora, requisito da medida cautelar, no sistema penitenciário, está consubstanciado na própria reclusão do ser humano.

Não é admissível, então, que o juiz mantenha o preso em regime fechado, para aguardar a vinda aos autos de qualquer documento que não esteja presente na data em que a lei prescreve para a progressão de regime. Se qualquer falta disciplinar deve ser comunicada ao juiz da execução, conforme o disposto no art. 153 e no parágrafo único do art. 48, ambos da 
LEP, havendo a comprovação de que o preso já cumpriu tempo de pena suficiente para ser transferido de regime, e não estando nos autos qualquer comunicação de falta grave, a sua progressão se impõe, ainda que cautelarmente. O fumus boni iuris e o periculum in mora, requisitos da medida cautelar estarão presentes, aquele, resultado do tempo de pena cumprido sem informação de infração disciplinar e este, na situação de risco que corre o apenado se mantido em regime mais grave além do período previsto em lei.

Cumprido o tempo de pena necessário para a progressão de regime, ou para a concessão de qualquer direito previsto em lei, que amenize ou abrevie o tempo de privação de liberdade, deve o magistrado providenciar para que o apenado seja imediatamente posto na situação menos desfavorável. Diante da obrigação de a direção do estabelecimento penal comunicar ao juízo da execução qualquer infração disciplinar, presume-se sempre de bom comportamento o preso, quando não houver o comunicado, portanto, perfeitamente viável a antecipação da tutela penal.

Não obstante, não é como tem agido a jurisprudência majoritária, ocorrendo que muitos magistrados têm mesmo determinado que o preso volte para o regime fechado a fim de que se realize exame criminológico ${ }^{192}$, o que, como acima demonstrado, já deveria ter sido realizado no início do cumprimento da pena. No caso, o que se tem feito é prejudicar o preso pela inoperância, inércia e incúria do próprio Estado.

O poder geral de cautela como forma de garantia da liberdade cerceada irregularmente não deriva somente dos pressupostos genéricos da medida cautelar. No processo penal e no processo de execução penal, o resguardo do status libertatis do cidadão é exigência reforçada por outros dispositivos legais. Os artigos 647 e 648 do CPP, por exemplo, consideram coação ilegal manter alguém preso por mais tempo do que determina a lei, situação passível de concessão de habeas corpus.

192 “...Efetivamente o reeducando em questão se encontra recluso por crimes graves, demonstrando possuir personalidade já corrompida pela criminalidade, assim, simples inércia no cumprimento da pena não é suficiente para se falar em presença de mérito. Diante de tal dúvida, neste caso, se faz necessária a realização de exame criminológico. Dado parcial provimento ao agravo para determinar retorno do agravado ao regime fechado para realização de exame criminológico". (TJSP, 5ª Cam. Crim., Ag. Ex. nº 0176456-53.2010.8.26.0000, Rel. Des. Sérgio Ribas, j. 03/03/11). No mesmo sentido: TJSP, 9a Cam. Crim, Ag. Ex. no 0545142-24.2010.8.26.0000, Rel. Des. Nuevo Campos, j. 03/03/11; 4ª Cam. Crim., Ag. Ex. nº 0394975-92.2010.8.26.0000, Rel. Des. Edilson Brandão, j. 22/02/11; 3 ${ }^{\text {a }}$ Cam. Crim., Ag. Ex. no 0398053-94.2010.8.26.0000, Rel. Des. Ruy Alberto Leme Cavalheiro, j. 08/02/11; 15 ${ }^{\text {a }}$ Cam. Crim., Ag. Ex. no 0348026-10.2010.8.26.0000, Rel. Des. Camilo Léllis, j. 24/02/11. 
E o artigo $5^{\circ}$, LXV, da Constituição Federal, de forma ampla determina que "a prisão ilegal será imediatamente relaxada pela autoridade judiciária”, indicando que, independentemente de qualquer procedimento, requerimento ou mesmo impetração de habeas corpus, o magistrado deve imediatamente agir para fazer cessar qualquer constrição à liberdade. Assim, se o apenado possui direito ao regime semiaberto ou ao aberto, direito este que se demonstra perfeitamente viável conforme os documentos que constam nos autos, não há como retardar a transferência de regime sob pena de se estar incorrendo em evidente constrangimento ilegal.

Às regras que colocam o magistrado na posição de guardião da liberdade soma-se outra garantia constitucional: a do inciso LXXVIII, do art. $5^{\circ}$, da CF, que assegura a todos, no âmbito judicial e administrativo, "a razoável duração do processo e os meios que garantam a celeridade de sua tramitação". O direito à razoável duração do processo não pode permitir as situações que vimos nos acórdãos antes citados, onde se mantém o preso no regime fechado aguardando realização de exame que por lei deveria ter sido feito no início da pena ${ }^{193}$.

A garantia da razoável duração do processo foi introduzida no art. $5^{\circ}$ da CF pela emenda da Reforma do Judiciário (Emenda Constitucional $n^{\circ} 45$, de 2004), a mesma que concebeu a súmula vinculante, e aos poucos vai sendo admitida e aplicada no âmbito da execução penal:

EMENTA: PENAL. EXECUÇÃO PENAL. HABEAS CORPUS. ART. 112 DA LEI 7.210/84, COM A REDAÇÃO DADA PELA LEI 10.792/03. PROGRESSÃO DE REGIME. REQUISITOS SUBJETIVOS. EXAME CRIMINOLÓGICO. DISPENSABILIDADE. EXCEPCIONALIDADE DO CASO CONCRETO. ORDEM CONCEDIDA. I - Nada impede que o magistrado das execuções criminais, facultativamente, requisite o exame criminológico e o utilize como fundamento da decisão que julga o pedido de progressão. II - Paciente que já cumpriu, de há muito, mais de 3/4 da pena. III - Na espécie, a realização do exame criminológico não seria concluída antes do cumprimento integral da pena restritiva de liberdade. IV - Direito à razoável duração dos processos administrativos e judiciais. Art. $5^{\circ}$, LXXVIII, da Constituição. V - Ordem concedida para assegurar a liberdade condicional ao paciente, nos termos que vierem a ser estabelecidos pelo Juízo da Execução (STF, $1^{\circ}$

${ }^{193}$ É o caso da decisão no Agravo de Execução n o 0422934-38.2010.8.26.0000 (TJSP, 3 a Cam. Crim., Rel. Des. Ruy Aberto Leme Cavalheiro, j. 15/02/11), em que o apenado foi obrigado a voltar para o regime fechado para realizar exame criminológico, mesmo já tendo ultrapassado mais de um ano do tempo que seria necessário para estar no regime semiaberto. Diga-se de passagem que o exame poderia ter sido realizado no próprio regime semiaberto no qual cumpria pena. 
Turma, HC 93108, Relator p/ Acórdão: Min. Ricardo Lewandowski, j. $25 / 11 / 2008)^{194}$.

A decisão acima é exemplo crasso de quanto um preso pode esperar para ver efetivado seu direito à liberdade. A garantia à razoável duração do processo veio tarde, após ter o processo passado por todas as instâncias judiciais possíveis, quando, segundo consta na ementa, o apenado já havia cumprido quase a totalidade da pena. E em situação idêntica estão inúmeros brasileiros que cumprem pena no nosso país, desde a mais longínqua comarca à capital brasileira.

Nada mais fez, o ministro Lewandowski, do que cautelarmente garantir a liberdade de preso que já havia cumprido período de pena excessivo. Tendo sido a medida tomada em habeas corpus, considerou o STF que o retardo na concessão de direito inerente à execução penal era tido como constrangimento ilegal. Por isso que tal decisão poderia e deveria ter sido proferida em primeira instância, em cumprimento ao art. $5^{\circ}, \mathrm{LXV}$, da CF, evitando-se que o constrangimento ilegal se prolongasse, como de fato ocorreu.

O ideal ressocializador é tão volúvel que tem sido usado para determinar o retorno ao regime fechado, do preso que não realizou o exame criminológico e progrediu para o regime semiaberto, conforme decisões já examinadas, assim como tem sido igualmente usado para posicionamento totalmente oposto, ou seja, para permitir que o apenado aguarde no regime semiaberto a realização do exame ${ }^{195}$. Se o preso fosse considerado um sujeito de direitos que tão somente cumpre a pena relativa ao crime pelo qual foi condenado, podendo ter seu direito de liberdade analisado e garantido com base no princípio da legalidade, tanta incoerência seria afastada.

\footnotetext{
${ }^{194}$ No mesmo sentido: TJRJ, $2^{\text {a }}$ Cam. Crim., HC 1.0000.09.490453-9/000(1), Rel. Des. José Antônio Baía Borges, j. 16/04/09; HC 1.0000.08.470790-0/000(1), Rel. Des. Herculano Rodriges, j. 10/04/08.

${ }_{195}$ Utilizando-se do argumento ressocializador, o STF permitiu que o apenado fosse mantido no regime semiaberto para que se realizasse exame criminológico que deveria ter sido concluído no regime fechado. Neste caso específico o sentenciado estava já há dois anos no regime semiaberto. (STF, 2 ${ }^{\mathrm{a}}$ Turma, RHC 103735, Rel. Min. Gilmar Medes, j. 05/10/2010). No mesmo sentido decisão do STJ: $5^{\text {a }}$ Turma, HC 139.151/SP, Rel. Min. Arnaldo Esteves Lima, j.18/05/2010).
} 


\subsection{6 Últimas considerações sobre o exame criminológico}

Quanto à função da CTC junto à administração penitenciária, mantemos o que foi dito no início, de que a lei abre espaços para uma ação eminentemente interdisciplinar. Falaremos mais adiante (4.2.1) sobre a importância do técnico na atividade estatal que pretende manter um nível mínimo de diálogo com os membros da comunidade que erraram. O que não pode é a liberdade de quem quer que seja ficar subordinada a subjetivismos incompatíveis com o princípio da legalidade.

Na obra já citada de Maria Palma Wolff há a relação de inúmeras situações onde prejulgamentos, preconceitos, deficiências técnicas, exercício deliberado de poder e sentimentos interferem na avaliação dos membros da CTC, que "longe de operar a neutralidade técnica e científica, produz sujeição" (2005, p. 169). E note-se que o trabalho da professora gaúcha é relacionado principalmente à atividade dos técnicos, situação que se agrava se levarmos em consideração que a atividade da CTC, com todos os seus defeitos, passará por um novo crivo, com mais preconceito, o crivo do judiciário, este que não tem se furtado em utilizar termos técnicos e observações sobre a personalidade do preso para negar direitos previstos em lei.

Não só “o arbítrio do juiz é enormemente aumentado em razão desta capacidade de julgar tecnicamente, que a ciência da criminologia lhe outorgou" (RAUTER, 2003, p. 71), mas os distúrbios de interpretação inerentes à natureza complexa da linguagem tornam demasiadamente obscura a avaliação da personalidade do condenado. Começando pela fala do preso que já é resultado de uma consciência enfraquecida pela sua própria situação de encarcerado, passando pela interpretação do técnico, pela transcrição desta interpretação, até chegar a uma nova avaliação a ser feita em juízo, a verdadeira história desse cidadão e o seu futuro estarão relegados à mais imprecisa sorte.

Portanto o gargalo de saída do sistema penitenciário não é estreitado apenas pelos inúmeros procedimentos que são realizados - quando são - extemporaneamente. O gargalo é reduzido duplamente com as diversas considerações subjetivas sobre o comportamento

passado e futuro do preso. Da dificuldade de avaliação do comportamento do apenado no sistema penitenciário passa-se para a liberdade de uso desse estudo por parte de promotores e 
juízes, tudo a fazer da execução da pena algo sobremodo misterioso, incompatível com qualquer garantia legal

Já falamos da difícil tarefa da CTC, diante de suas condições de trabalho, precárias política, material e psicologicamente, mas sempre é bom repetir que o exame criminológico, como qualquer atividade dos agentes que compõem essa comissão, pressupõe, antes de tudo, um encontro. Uma troca de informações, de sentimentos, de expectativas, entre duas ou mais pessoas. Aqui, literalmente, e na forma mais bruta da palavra, há que ter um diálogo.

Assim, o técnico cego, escravo do sistema, sem reflexão sobre as violências e injustiças do cárcere, nunca estará preparado para este diálogo. Na sua atividade, no seu exame, nunca haverá nada de sincero, nem de sua parte nem da parte do preso. O que haverá é uma reprodução da relação policial que vem acompanhando o preso há tempos, camuflando e aumentando as violações do sistema.

Entretanto, apesar de toda essa desordem e desencontros, o processo, como vimos, tem chegado ao magistrado para uma nova interpretação, o que será feito em um gabinete do fórum, distante quilômetros de onde se passa a vida e se forma a (des)personalização daquele que está sendo examinado mais uma vez. O uso livre por parte do magistrado do que foi colhido pelo psicólogo da CTC, tem sido comum, sendo interessante trazer aqui alguns exemplos.

O HC 0342794-17.2010.8.26.0000 (TJSP, 6a Cam. Crim., Rel. Des. Machado Andrade, j. 03/03/11), traz a informação de que o direito ao regime aberto de preso que já se encontrava no semiaberto, e possuía tempo para a progressão, foi negado porque a psicóloga declarou “'haver dificuldade em estabelecer prognóstico de adaptação ao regime', por entender que os elementos disponíveis não ofereciam segurança para concluir-se pela recuperação do paciente".

Já o Agravo de Execução Penal no 0433691-91.2010.8.26.0000 (TJSP, 1ª Cam. Crim., Des. Rel. Figueiredo Gonçalves, j. 28/02/11) noticia e mantém decisão que negou a progressão para o regime semiaberto porque o preso seria "oportunista, com desejo de ver resultados imediatos, impaciente, com boa auto-estima, mas também com uma certa falta de autonomia e algum sentimento de rejeição". 
Desnecessário comentar a fraca consistência dos argumentos utilizados para se negar direito inerente ao processo de execução penal, mas interessante e importante registrar a constatação de que nessas duas decisões acima citadas os magistrados alegaram também que não concederiam a progressão porque, diante do excessivo tempo de pena a cumprir, seria prematuro o benefício. Ora, desta forma, nem o preso, nem a sociedade, nem ninguém saberá nunca o tempo de pena que verdadeiramente deve ser cumprido, e a sanção, que era para ser legal, passa a ser subordinada ao sentimento de (in)justiça da pessoa do juiz.

Continuando, no Agravo em Execução no 0439708-46.210.8.26.0000 (TJSP, 14 ${ }^{\mathrm{a}}$ Cam. Crim., Des. Rel. Fernando Torres Garcia, j. 24/02/11), o indeferimento da progressão foi mantido, uma vez que "assinalou-se que o sentenciado '... demonstrou um comportamento colaborativo, porém aparentemente um discurso pronto e planos simplistas"”. Do Agravo $\mathrm{n}^{\circ}$ 70039819511 (TJRS, 3 ${ }^{\text {a }}$ Cam. Crim. Des. Rel. Odoné Sanguiné, j. 10/02/11) extrai-se que o preso "não está apto a adaptar-se ao regime menos rigoroso e a reintegração ao ambiente de origem, necessita resgatar os vínculos familiares como forma de alternativa de ressocialização".

Esta última observação, de que o apenado, preso, deve se reintegrar ao ambiente de origem e resgatar os vínculos familiares lembra a comum advertência de que não se pode aprender a nadar fora d'água (SILVA, 2009). Não há como imaginar uma aula de natação teórica. E é o que espera o acórdão, que o preso aprenda a conviver em sociedade, restaurando seus laços familiares, sem sair da prisão. Diante da impossibilidade: mais punição.

No Agravo no 70040886624 (TJRS, 7 a Cam. Crim., Des. Rel. Sylvio Baptista Neto, j. 10/02/11), relacionado a pena aplicada por crime de atentado violento ao pudor, o apenado teve a progressão negada e uma das considerações foi a de que "não tendo oportunidade de trabalho, o crime é sua alternativa natural de sobrevivência". Um verdadeiro julgamento pela situação de vida, porque, a princípio, o crime cometido não tem qualquer vínculo com o fato de o sentenciado trabalhar ou não: trata-se de delito contra a liberdade sexual e não contra a propriedade.

Poderíamos buscar e trazer inúmeros outros exemplos de incoerências, todavia nosso trabalho não tem isto como tema específico. A facilidade de encontrar tais decisões só é 
indício do quanto elas são uma constante. O que pretendemos que tenha ficado bem explícito é que tais avaliações de personalidade, sejam as do psicólogo, sejam as da CTC como um todo, sejam as da direção do estabelecimento penal e, principalmente, as dos juízes, nenhuma dessas seria admissível se realmente o preso fosse considerado um sujeito de direitos e a pena estivesse, na fase de execução penal, subordinada ao princípio constitucional da legalidade.

Não obstante determinado nível de subjetividade ser inerente a qualquer julgamento, não pode o Estado admitir qualquer situação que favoreça o acréscimo de subjetivismo na execução. Que os julgamentos sejam restritos e feitos sobre fatos e não sobre a história de vida de cada um. O próprio Freud que, partindo de suas primeiras teorias do trauma como desencadeador da neurose, teria "construído o modelo segundo o qual a partir dos fatos do passado é que se compreende o funcionamento psíquico do presente” (RAUTER, 2003, p. 88), quando consultado sobre a sua biografia pessoal, não achou boa a ideia de escrevê-la, vez que estaria sempre "comprometida com a mentira, ocultações, hipocrisia, lisonja e até com o encobrimento da própria falta de entendimento, pois a verdade biográfica não existe" (COHEN, 2010, p. 173).

O Estado Democrático de Direito tem que arcar com as consequências de ser um Estado de garantias, porque estas não são deste ou daquele, mas de todos nós. O direito penal do autor deve ser completamente abolido para dar espaço ao princípio da legalidade. Enquanto for possível punir sentimentos com base em sentimentos, paixões com base em paixões, dores com base em dores, desejos com base em desejos, nada haverá de ciência, nada haverá de garantia. Que se punam fatos e a subjetividade se restrinja a estes. 


\section{A DIGNIDADE DA PESSOA HUMANA COMO PARADIGMA}

\subsection{Ressocialização versus legalidade e dignidade da pessoa humana}

No transcurso deste trabalho vimos defendendo que o ideal de ressocialização fosse substituído pelo seu verdadeiro objetivo, a consideração da dignidade da pessoa humana na prática jurisdicional e no tratamento direto para com o preso. Mas sempre poderá vir a dúvida, igualmente já referida, a respeito de se realmente seria esta substituição um grande avanço. Estamos convencidos de que sim.

Não é fácil imaginar um tribunal ou juiz fundamentar um tempo maior de prisão, a negação de um direito qualquer que colocará o ser humano mais próximo da liberdade, com o argumento de que assim está agindo em função do princípio da dignidade da pessoa humana. A substituição que se pretende acabaria acarretando um grande obstáculo na comunicação de normas desse tipo.

$\mathrm{O}$ argumento ressocialização, como vimos, tem inúmeras utilidades e sua ambiguidade serve para dar uma aparência de decisão humana para algo que visa tão somente fazer sofrer o cidadão objeto do direito penal. É palavra que se encaixa como fundamentação para o aumento de pena ou para a negação de direitos, como se o magistrado estivesse fazendo um bem ao invés de um mal. No caso, sem interessar o que pensa e o que sente o verdadeiro destinatário da punição.

Basta a constatação de haver tribunais usando o argumento ressocializador para encarcerar e já notamos um grande distúrbio na comunicação que deveria ter a atividade judicial e o direito. Como dizer "ele vai ficar preso mais tempo para se ressocializar" e não parecer ridículo aos ouvidos da própria opinião pública, mesmo esta que sempre está sedenta por mais punição? E é o que os tribunais têm feito sem qualquer preocupação com a coerência de seus julgamentos.

Nas decisões que dizem estar em prol da ressocialização e encarceram ao mesmo tempo, acontece o parecido com o que Shecaira demonstra ocorrer no Direito Penal Juvenil e que denomina de paradigma da ambiguidade, ou seja, os julgadores "argumentam que, sendo 
as medidas sócio-educativas um bem, até mesmo as institucionais, não há por que livrar o adolescente do sistema encarcerador" (2008, p. 153)

$\mathrm{Na}$ análise jurisprudencial dissemos não ser nossa preocupação provar se tal ou qual decisão era majoritária ou não, bastando a comprovação de que há decisões usando a palavra ressocialização para agravar a pena. Todavia, deve ficar registrado que no cômputo geral, até para a nossa surpresa, ressocialização é um termo usado pelos tribunais, na maioria das vezes em prejuízo do preso. O uso da internet facilita, e basta, na utilização dos mecanismos de busca nos sites dos tribunais, colocar a palavra ressocialização e se verá que grande parte das decisões usando tal vocábulo é negativa.

Das últimas 500 decisões pesquisadas, temos 257 usando o termo ressocialização em prejuízo do preso, e 243 em favor, sendo São Paulo o Estado que mais incorre nessa prática pois, dentre 100 decisões, aparecem 69 negativas. De acordo com os Estados pesquisados, podemos apresentar o seguinte gráfico:

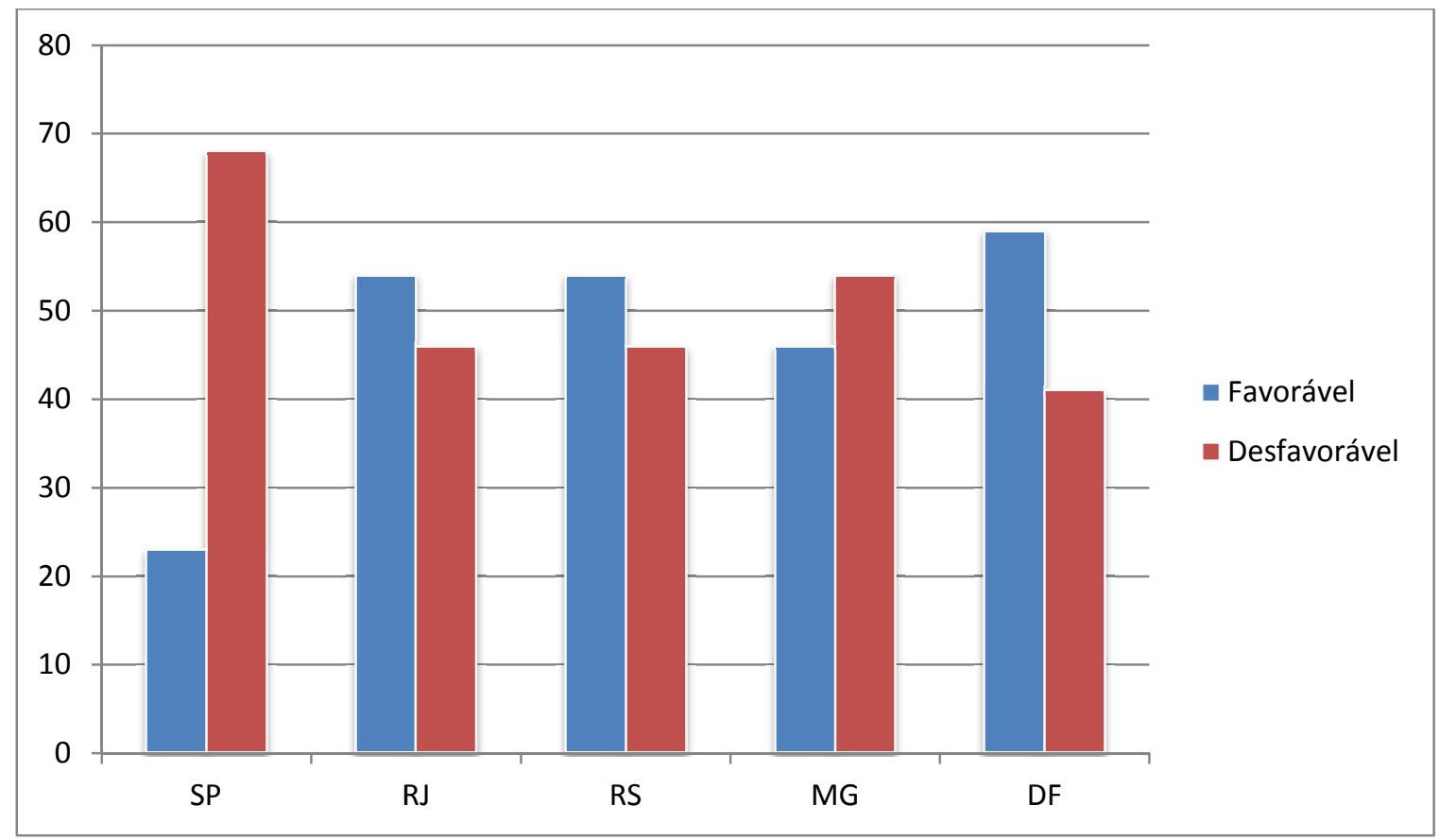


Das 257 decisões negativas, ou seja, que negam algum direito ou agravam o cumprimento da pena utilizando a ressocialização como argumento, 26,84\% são de São Paulo, enquanto 21,01\% são de Minas Gerais, o segundo Estado em quantidade de decisões desfavoráveis com as características estudadas ( 54 desfavoráveis e 46 favoráveis).

Os Estados do Rio de Janeiro (18,28\%) e Rio Grande do Sul (17,89\%), assim como o Distrito Federal $(15,93 \%)$ possuem mais decisões favoráveis ao preso do que negativas, com o uso do termo ressocialização, como visto no gráfico, mas ainda assim com pouca diferença. De 100 decisões, o Rio de Janeiro tem 53 favoráveis e 47 desfavoráveis; o Rio Grande do Sul, 54 favoráveis e 46 desfavoráveis; e o Distrito Federal, 59 favoráveis e 41 desfavoráveis.

Nossa pesquisa partiu do mês de fevereiro de 2012 para trás, até completar 100 decisões em cada Estado, devendo-se registrar, entretanto, que apesar de São Paulo possuir o maior número de decisões negativas com o termo ressocialização, com certeza é neste Estado, por sua grande quantidade de julgamentos, que as decisões mais devem variar, sendo a porção de decisões ali coletadas, insuficiente para se indicar uma tendência.

Um gráfico das 257 decisões negativas encontradas, dividas por Estado, ficaria da seguinte forma:

\section{Decisões Negativas}

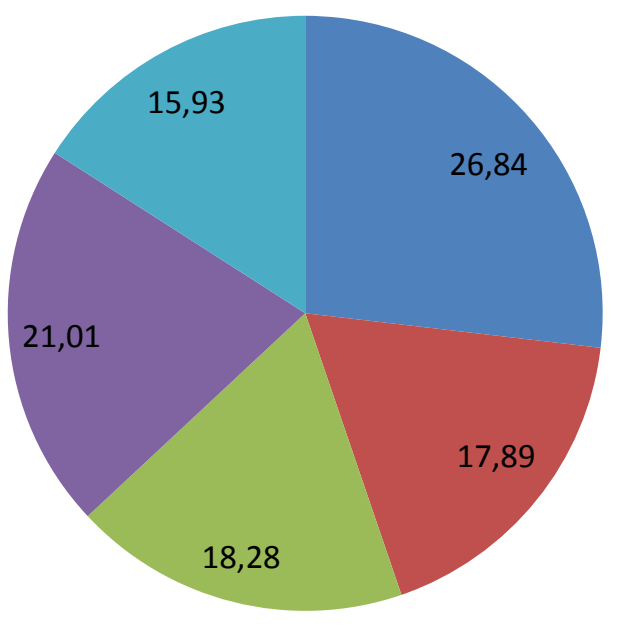


Assim, persistimos na defesa de que a palavra ressocialização, se abolida do vocabulário jurídico, proporcionaria mais vantagens para uma interpretação que desprestigiasse o encarceramento do que desvantagens. Todo conteúdo humanitário que há na ideia ressocializadora pode ser substituído pelo princípio constitucional da dignidade da pessoa humana.

Ora, o princípio da dignidade da pessoa humana não se presta tão facilmente para a finalidade de encarcerar, como tem servido a ressocialização. Não há como o juiz dizer: “Aumento a sanção penal em 3 anos em prol da dignidade da pessoa humana"; ou "- Indefiro o livramento condicional, mantendo o apenado em regime fechado, em penitenciária de segurança máxima, para fins de resguardo da dignidade da pessoa humana". São afirmações que não soam bem ou soam contraditórias, expondo as decisões.

Se é certo que o termo ressocialização também não deveria soar bem, pois ideal exaustivamente refutado pela realidade, como ideal acaba permanecendo viável. Dignidade da pessoa humana, muito mais do que um ideal, é situação de fato e perfeitamente verificável, principalmente em circunstâncias de violação, como é o caso da pena privativa de liberdade.

Não restam dúvidas de que a dignidade é algo real, algo vivenciado concretamente por cada ser humano, já que não se verifica maior dificuldade em identificar claramente muitas das situações em que é espezinhada e agredida, ainda que não seja possível estabelecer uma pauta exaustiva de violações da dignidade (SARLET, 2007, p. 364).

O princípio da dignidade da pessoa humana é anteparo suficiente para que o direito penal não se torne uma cega retribuição, o que pareceria ser o caminho de um direito punitivo sem ideal ou, como queiram, sem uma finalidade científica. Não é necessário, portanto, fazer uso de ideais imprecisos que têm servido duplamente, em favor da dignidade do ser humano e como fundamento para a violação desta.

Não há como se recear perder o pouco que anos de reivindicação ressocializadora conquistaram de reforma e melhoria no campo penitenciário, porque todos esses progressos podem perfeitamente ser mantidos com o argumento de assim se estar fazendo em nome da dignidade da pessoa humana. A progressão de regime, que também foi responsável pelo aumento das penas, pode ser preservada como ingrediente de esperança na pena privativa de liberdade e, portanto, com base na necessária dignidade do ser humano; o trabalho prisional 
também não precisa do ideal ressocializador e pode ser defendido com base no argumento de que o abandono em uma instituição do Estado é indigno para qualquer um; e assim por diante. Estando a dignidade da pessoa humana como objetivo primeiro do projeto ressocializador, tudo o que foi alcançado por este de positivo pode ser mantido com o abandono do ideal e a assunção do verdadeiro propósito.

Oportuna a lição de Karl Popper de que a ciência se faz menos pelo acúmulo de verdades e mais, "sobretudo por eliminação de erros na procura da verdade" (MORIN, 2010, p. 148). E a hipótese aqui é justamente esta, a de que adotado o princípio da dignidade da pessoa humana como parâmetro do direito penal, este erre menos do que tem errado ao aceitar o volúvel ideal de ressocialização.

Por outro lado, a defesa que se faz do princípio da legalidade não é ingênua. Sabe-se que a estrita legalidade pura e simples não é caminho certo para a Justiça. Todavia, em sede de execução penal ainda não estamos próximos nem mesmo da legalidade liberal iluminista de Beccaria. A barbárie que toma conta de cadeias e prisões cega o profissional da execução penal, técnico ou jurista, este também cada vez mais técnico do que jurista, fazendo do princípio da legalidade algo a ser alcançado.

Com todas as suas deficiências e mutilações, a Lei de Execução Penal, se cumprida no que se refere ao respeito do ser humano preso, serviria como ótimo instrumento para uma pena com menos violência. A segurança e a certeza do princípio da legalidade são benefícios que o condenado não conhece.

Ainda que se possa afirmar que a legalidade extrema engessa e obstaculiza avanços do Direito, o qual deve acompanhar as mudanças sociais, "sem um mínimo de certeza e segurança jurídicas, não poderia reinar a justiça na vida social (não pode haver justiça onde não existe ordem)", como adverte Lídia Prado citando Recaséns Siches: “mesmo porque, a certeza e segurança, embora de qualidade inferior em relação a valores como justiça e o bem comum, condicionam a realização dessas aspirações mais altas” (1996, p. 145).

No dizer de Eros Grau, “o nosso drama está em que a legalidade e o procedimento legal resultam, inúmeras vezes, perversos e violentos, funcionando como nossas derradeiras defesas, contudo, contra a perversidade e a violência” (2008, p. 169). A legalidade é o mínimo 
(ou o mínimo de legalidade é o necessário) para se almejar qualquer progresso no caminho de uma execução penal menos desumana.

Ressocialização é o oposto de legalidade, uma vez que a ambiguidade daquela abre espaços para fundamentar qualquer conduta, em uma ação arbitrária da pior espécie, pois camuflada de boas intenções. O conteúdo normativo em si pode ser tido como arbitrário, mas será menos se for "obtido e justificado a partir do potencial racional imanente à práxis cotidiana” (HABERMAS, 2000, p. 473). Portanto a verdadeira legalidade é aquela que leva em consideração a realidade, constatação que reforça a oposição do princípio da legalidade do ideal ressocializador, principalmente quando este vem acompanhado da prisão.

Deveria ser suficiente dizer que o princípio da dignidade da pessoa humana é fundamento do Estado Democrático de Direito, na letra da Constituição Federal, e que o princípio da legalidade é a base do direito penal desse Estado; assim estaria vedada qualquer consideração oriunda da intenção ressocializadora de quem quer que seja, na atividade punitiva, mas a prática judicial demonstrou o contrário. Por isso não deve cessar a defesa da estrita legalidade, somada ao respeito à dignidade da pessoa humana do preso, para que depois, somente depois, possamos avançar dizendo que o direito cumpre seu papel como instrumento comunicativo.

\subsection{A reintegração social: uma proposta}

É sobre uma possibilidade de avanço que se quer falar agora, uma postura que Alessandro Baratta designa reintegração social (2006). Entretanto, repita-se, não acreditamos em nenhuma superação no sentido de uma execução penal mais científica, que não seja respeitando garantias básicas no tratamento do sujeito do Direito Penal. Qualquer construção científica, conquanto tenha a melhor das intenções, não passará de mais uma legitimação da violência diária de nossas prisões, se não levar em conta tal situação.

Apesar de termos exposto decisões judiciais que desconsideram a realidade das prisões, demonstrando a incoerência da prática judicial na execução da pena, também não acreditamos na mudança da situação do sistema penitenciário por intermédio dos tribunais. Estes estão cada dia mais distantes do cidadão do Direito Penal e a abstração que fazem da real condição 
do cárcere é indício de que não se devem esperar mudanças de instituições que compõem a superestrutura estatal.

Um juiz pode, é claro, e tem grandes possibilidades para tanto, ajudar na desconstrução das engrenagens desumanas desse sistema, mas deve sair do local que lhe é reservado, deve-se despir da toga e descer os degraus da hierarquia social em que o Judiciário é posto, para ver o preso como igual, um semelhante.

Neste ponto é imprescindível repisar uma diferenciação. Há dois mundos no sistema penal: o mundo jurídico, das leis, do judiciário; e o mundo real, o das prisões, das relações para com os presos e entre estes, suas famílias etc. São dois mundos distantes entre si, sendo que o autismo do primeiro tem mais influencia sobre o segundo, do que o sofrimento deste sobre o primeiro.

Assim, o ideal de ressocialização, enquanto serve de acréscimo de subjetividade, encobrindo vários sentimentos negativos relacionados à punição e ao ódio em decisões judiciais, prejudicando qualquer pretensa objetividade da lei, na vida real do sistema penitenciário, serve como reforço da noção de tratamento, valorizando uma postura de superioridade dos técnicos e do pessoal penitenciário em geral, criando um abismo entre pessoas que convivem diariamente: presos e técnicos.

Cabe então especificar em que campo Alvino Augusto de Sá insere a tese de Alessandro Baratta, a respeito da reintegração social. Após mostrar que Baratta pretende substituir termos como ressocialização e reabilitação por reintegração, Sá explica que reintegração vem para "designar o objetivo a ser perseguido no trabalho de assistência aos presos e facilitar-lhes o reingresso na sociedade", continuando ainda o professor da Universidade de São Paulo a ensinar que reintegração seria "todo um processo de abertura do cárcere para a sociedade e de abertura da sociedade para o cárcere e de tornar o cárcere cada vez menos cárcere, no qual a sociedade tem um compromisso, um papel ativo e fundamental" (2010, p. 162).

Então reintegração social seria, ao menos para efeito do nosso estudo, uma atividade inerente ao campo do sistema penitenciário e não mais um dogma jurídico componente da atividade jurisdicional. Reintegração social seria uma mudança de postura de agentes, da 
sociedade (e talvez até alcançando o Judiciário por esse intermédio), frente ao preso, que não seria mais tratado como objeto, mas sim como sujeito.

$\mathrm{Na}$ verdade, essa mudança de postura que pede a reintegração social, a nosso ver, não necessitaria de uma nova nomenclatura, notadamente sendo algo que se confunde com o que se pretende substituir. Nossa pesquisa jurisprudencial mostrou que, na prática, na linguagem jurídica e, principalmente na linguagem comum, reintegração é sinônimo de ressocialização ${ }^{196}$.

Mas a ciência precisa explicar, demonstrar e provar. Por isso, a alteração de atitude frente ao preso, que se quer levar a efeito, com a sociedade se comprometendo nessa mudança, "buscando revisar suas concepções e suas relações de antagonismo com os excluídos que estão presos, buscando pois se re-posicionar, reatar o diálogo com essas pessoas, auxiliando-as a se promoverem como cidadãos" (SÁ, Op. Cit., p. 173), por isso essa nova diretriz, para ganhar força e legitimidade científica, precisa ser denominada e a nomenclatura escolhida foi reintegração social.

Não há dúvidas sobre as vantagens dessa modificação de postura, mas até que ponto nominá-la não seria correr o risco de se criar mais uma legitimação para um sistema penitenciário que nem ressocializa e nem reintegra? Afastada a ideia de que se pretende favorecer a dignidade da pessoa humana com o projeto de reintegração social, pois este também foi o projeto da ressocialização, a reintegração, por ser algo que viria para incrementar o diálogo, abrir o cárcere para a comunidade e caminhar na direção de outro ponto de vista sobre o preso, dificilmente poderia ser uma designação satisfatória. Insta, talvez, reconhecer a limitação da linguagem para abarcar tal conduta.

O correto é perquirir o próprio Alessandro Baratta sobre o que vem a ser reintegração social:

Considero que redefinir os tradicionais conceitos de tratamento e ressocialização em termos de exercício dos direitos dos cidadãos detidos, e em termos de serviços e

\footnotetext{
${ }^{196}$ Apenas como exemplo, repete-se trecho de acórdão nesse sentido: "O cumprimento de pena no regime semiaberto constitui uma fase obrigatória, tendo em vista que o objetivo do instituto da progressão prisional é de reabilitação do sentenciado, de modo a permitir a sua reintegração no convívio social [...] (TJESP - $16^{\mathrm{a}}$ Câm. Crim. - Ag. 990.09.107545-0 / Tupã - Rel. Des. Pedro Luiz Aguirre Menin - voto 5.020. v. u. - j. em 15.09.2009).
} 
oportunidades laborais e sociais que lhes são proporcionadas durante e depois da detenção, por parte das instituições e das comunidades, constitui um núcleo importante da construção de uma teoria e uma prática novas, de reintegração social dos condenados, conforme uma interpretação progressista dos princípios e das normas constitucionais e internacionais em matéria de pena ${ }^{197}$ (2006, p. 382).

Vê-se que Baratta não limita a reintegração social às atividades do pessoal penitenciário, específicas do cotidiano carcerário. Quando fala de interpretação progressista de princípios e normas, obviamente está se dirigindo à prática jurisdicional, portanto todo cuidado é pouco na designação de conceitos, principalmente conceitos de conteúdo amplo que, nesta área, têm sido preenchidos de forma livre e desvinculada de seus propósitos iniciais.

Baratta reconhece o fim da utopia ressocializadora, mas demonstra evidente preocupação de que tal constatação possa levar a um reforço das funções de retribuição e neutralização da pena. Sua construção teórica seria no sentido de não se abandonar o projeto humanizador das prisões, a fim igualmente de contrapor alguma resistência ao abandono dos cárceres e à política das prisões de segurança máxima. Ao mesmo tempo, sempre esteve presente em Baratta a consciência do mal que é a prisão.

Não se pode conseguir a reintegração social do condenado por intermédio da pena de prisão, mas se deve perseguí-la apesar da prisão, ou seja, buscando fazer menos negativas as condições de vida no cárcere. Do ponto de vista de uma integração social do autor de um delito, o melhor cárcere é, sem dúvida, aquele que não existe ${ }^{198}$ (Idem, p. 379).

O professor italiano não deixou de demonstrar a mesma preocupação acima referida. De que a reintegração social acabasse se transformando em nova legitimação do cárcere. Como Baratta, Alvino Sá (2010) também enfatiza o fato de que a reintegração deve se dar apesar do cárcere. Este "apesar do", para os autores citados, é suficiente para demonstrar que não defendem a prisão, mas um tratamento mais humano para com os presos, um diálogo entre

\footnotetext{
${ }^{197}$ Na obra consultada:"Considero que redefinir los tradicionales conceptos de tratamiento y resocialización en términos de ejercicio de los derechos de los ciudadanos retenidos, y en términos de servicios y de oportunidades laborales y sociales que se les proporciona durante y después de la detención, por parte de las instituciones y las comunidades, constituye un núcleo importante de la construcción de una teoría y una práctica nuevas, de reintegración social de los condenados, conforme a una interpretación progresista de los principios y de las normas constitucionales e internacionales en materia de pena" (BARATTA, 2006, p.382).

${ }^{198}$ Tradução livre de: "La reintegración social del condenado no puede perseguirse a través de la pena carcelaria, sino que deve perseguirse a pesar de Ella, o sea, buscando hacer menos negativas las condiciones que la vida en la cácel implica, en relación con esta finalidad. Desde el ponto de vista de una integración social del autor de un delito, la mejor cácel es, sin Duda, la que no existe" (Idem, p. 379).
} 
presos e a sociedade para a solução dos conflitos ou para a superação das situações de vulnerabilidade que levaram à prática delituosa.

Continua Baratta informando que a atividade de reintegração social deve zelar pelos direitos e destino das pessoas presas e deve "provir de uma vontade de mudança radical e humanista e não de um reformismo tecnocrático cuja finalidade e funções sejam as de legitimar, através de qualquer melhoramento, a instituição carcerária em seu conjunto"199 (Idem, p. 379). Em outras palavras, a reintegração social não seria uma simples teoria reformista, mas estaria compondo "uma estratégia reducionista a curto e médio prazo, e abolicionista a longo prazo",200 (Idem, Ibidem).

Permanecemos achando perfeitamente válido o desígnio de Baratta, mas a necessidade de se dar uma nomenclatura que, queira ele ou não, é reformista, ainda não nos convenceu. Ainda que seja possível reconstruir o pensamento penal ou penitenciário sobre a noção de reintegração como Baratta a concebe, a característica ambígua e volúvel do termo ressocialização continuará acompanhando com a mesma força a ideia de reintegração social.

Daí concluímos que, ao menos no que se refere á prática jurisdicional, à atuação dos tribunais, a troca de nomenclatura não surtiria os efeitos almejados e poderiam até surtir efeitos contrários. Permanecemos defendendo que o melhor caminho é assumir a pena como algo negativo, mas sempre levando em conta que nenhuma atividade judicial pode se afastar de uma interpretação que tenha em consideração a dignidade da pessoa humana e a realidade que é o cumprimento da pena privativa de liberdade.

Quanto à mudança de postura na lide diária dos profissionais das penitenciárias, quanto à abertura dos cárceres para a sociedade, quanto ao diálogo necessário para que a sociedade compreenda e se compreenda no contexto punitivo, uma designação nunca será suficiente, notadamente se esta fizer referência exclusivamente ao preso, como é o caso da reintegração, que sempre passará a ideia de que quem precisa se reintegrar é ele, o preso. No mínimo percebe-se que o termo reintegração social tem certa dose de imprevisibilidade e a

\footnotetext{
199 "provenga de una voluntad de cambio radical y humanista y no de un reformismo tecnocrático cuya finalidad y funciones sean las de legitimar, a través de cualquier mejoramento, la instituición carcelaria en su conjunto" (Idem, p. 379).

200“una estrategia reduccionista a corto y mediano plazo, y abolicionista a largo plazo" (Idem, Ibidem).
} 
previsibilidade é, "como se sabe, uma das condições da comunicação” (WOLTON, 2004, p. 76).

Mas Baratta tinha outro motivo para buscar uma reinterpretação (ele fala em redefinir os tradicionais conceitos de tratamento e ressocialização). A questão é que tanto na Itália, país natal do professor, quanto na Alemanha, local onde lecionava, há norma indicando que o fim da pena é a ressocialização do condenado ${ }^{201}$. Por isso, de seus textos se depreende clara intenção de superar a interpretação do ideal ressocializador, exposto na lei, em convenções internacionais e desenvolvido dogmaticamente durante anos.

Do art. 27 da Constituição italiana desenvolveu-se o princípio da "pena ressocializante", o qual, na concepção de Baratta, deve ser "reinterpretado em um marco mais amplo dos princípios constitucionais que inspiram o estado social de direito e, em particular, o princípio dinâmico da igualdade e da dignidade do homem"202 (Op. Cit., p. 20). Ora, é o que vimos defendendo desde o princípio, restando tão somente a dúvida de se seria realmente indispensável adotar uma nova designação para a atividade de se respeitar a dignidade da pessoa humana em sede de execução da pena.

Não seria o caso do Brasil, onde, como já afirmamos, nem a legislação penitenciária (a LEP), nem muito menos a Constituição Federal, assumem a ressocialização como fim da pena, mas adota, a primeira, a fórmula harmônica integração social do apenado (art. $1^{\circ}$ ). $\mathrm{O}$ legislador, mesmo influenciado pela ideologia do tratamento, com todos os resquícios positivistas que observamos anteriormente, não quis usar a palavra ressocialização. Portanto, ao menos no Brasil não há necessidade de uma reinterpretação do ideal ressocializador, há sim, necessidade de superá-lo.

\footnotetext{
201 A Constituição Italiana ainda em vigor expressamente declara que "as penas não podem consistir em tratamento contrário ao senso de humanidade e devem tender à reeducação do condenado" (Art. 27 - Le pene non possono consistire in trattamenti contrari al senso di umanità e devono tendere alla rieducazione del condennato). Baratta cita ainda a lei italiana 353, de 23 de julho de 1975, e a Lei Penitenciária Alemã, de 16 de março de 1976, como inspiradas no ideal de ressocialização (2006, p. 14).

202 "reinterpretado en el marco más amplio de los principios constitucionais que inspiran el estado social de derecho y, en particular, del principio dinámico de igualdad y del principio de la dignidad del hombre" (Op. Cit., p. 20) (Grifo no original).
} 
Se é verdade termos assinamos diversos tratados e convenções internacionais que trazem o ideal ressocializador como fim da pena expressamente declarado ${ }^{203}$, incorporando-os ao nosso ordenamento jurídico, é ideal que se deve considerar já devidamente reinterpretado na nossa legislação interna pela harmônica integração social da LEP. Termo este, diga-se de passagem, até mais compreensível do que o de reintegração, considerando, como se costuma repetir, nunca ter sido o preso integrado à sociedade.

Diálogo, respeito pelo preso como uma pessoa normal, sujeito de direitos, assistência do Estado e participação solidária por parte da sociedade, são ingredientes do princípio maior de respeito à dignidade da pessoa humana. Reintegração social, no caso, é termo que poderia ajudar para uma melhor elaboração metodológica, mas, de outro turno, poderia reforçar a subjetividade que tem prejudicado o cidadão preso. Para avançarmos, superarmos a estagnação da prática penal, "uma linguagem tem de ser construída. Não pode ser a linguagem na qual a justiça criminal é praticada e legitimada” (HULSMAN, 1997, p. 193).

Tecnicamente o que pretendeu Alessandro Baratta foi realizar uma definição estipulativa ou reestipulação do termo reintegração, conforme lição de Luís Alberto Warat:

"cada vez que se busca alterar as propriedades definitórias de uma expressão, inclusive nas hipóteses em que se procura modificar uma significação estipulativa anteriormente produzida, estamos frente a uma definição estipulativa. Algumas definições estipulativas, portanto, seria casos de reestipulação (...) O mesmo ocorre com os doutrinadores do direito. Estes, geralmente, afirmam que sua atividade específica é, precisamente, a de ministrar os sentidos lexicográficos das palavras da lei. Suas definições, inobstante, encerram prescrições encobertas, dadas mediante propostas veladas de mudanças de sentido. Suas definições são, portanto, estipulativas" (1977, p. 38-43).

Ocorre que a reestipulação de uma palavra, prática sempre arbitrária, traz o risco de falhar e reforçar os antigos valores que se procurava superar, principalmente quando o termo a ser reestipulado é tratado diversas vezes como sinônimo de outros guardando o sentido antigo, todos compondo o que se pode chamar, como já referido anteriormente, de "ideologias re". (ZAFFARONI; BATISTA; et al, 2003, p. 126).

\footnotetext{
${ }^{203}$ Como exemplo, o art. $5^{\circ}$ da Convenção Americana sobre Direitos Humanos/OEA, Pacto de San José da Costa: "Art. $5^{\circ} .6$ - As penas privativas de liberdade devem ter por finalidade essencial a reforma e a readaptação social do condenado"; e o Pacto Internacional de Direitos Civis e Políticos (ONU, Res. 2.200 - A [XXI], 16.12.66]: "Art. 10.3: "O regime penitenciário comportará tratamento dos reclusos cujo fim essencial é sua emenda e sua recuperação social”, vigorando no Brasil a partir do decreto 592, de 06.06.92 (MAIA Neto, 1998, p. 16-17).
} 
Na Carta de Direitos Humanos do Paraná para a América Latina, por exemplo, documento que foi originado do Congresso Latino Americano de Direitos Humanos, realizado entre os dias 17 e 20 de outubro de $1993^{204}$, com a participação, entre outros, de nomes como René Ariel Dotti e Zaffaroni, reintegração vem como sinônimo de reeducação e ressocialização:

"Refere-se a reintegração social, a reeducação, ou a readaptação do condenado, como forma de diminuir a reincidência criminosa dos condenados à pena privativa de liberdade. Em face das atuais condições de gerenciamento dos estabelecimentos penais e/ou das prisões, pode-se dizer que a ressocialização do apenado "é letra morta', vez que $90 \%$ dos ex-presidiários voltam a reincidir na prática de delitos" (MAIA Neto, 1998, p. 19).

Haroldo Caetano da Silva chega a traduzir a reintegração de Baratta como sendo a própria ressocialização: “Quando sustenta uma ressocialização que decorre não da prisão, mas que deve ser buscada apesar da prisão, Baratta reforça, mesmo que de maneira implícita, a ideia de que ressocialização é algo estranho a prisão" (2009, p. 46).

Maria Lúcia Karam refere que a "ressocialização, a pretender concretizar o objetivo de evitar que o autor do crime volte a delinquir, através da reeducação e reintegração à sociedade, é absolutamente incompatível com o fato da segregação" (2004, p. 81), aproximando, portanto, os conceitos de ressocialização e reintegração. Salo de Carvalho os tem, tais conceitos, como sinônimos: "Com efeito, a deslegitimação (invalidade) formal e material das normas que pretendem modificar o 'ser' do condenado sob a máxima da ressocialização, recuperação ou reintegração, é perfeitamente justificável” (2008, p.178).

Mesmo Baratta, quando diz que "a finalidade de uma reintegração do condenado à sociedade não deve ser abandonada, mas reinterpretada e reconstruída sobre uma base diferente"205 (2006, p. 378), não deixa de estar usando a sua nova designação, a reintegração, como a função antiga da ressocialização, causando certa imprecisão nos conceitos.

Estudos sobre comunicação sempre indicaram que "a dificuldade em definir um termo de modo que todas as pessoas empreguem da mesma maneira é muito maior do que se

\footnotetext{
${ }^{204}$ Importante notar que Alessandro Baratta vem defendendo uma reinterpretação do termo ressocialização por reintegração, no mínimo desde 1985, em texto publicado na obra "Doctrina Penal, año 8, n 29-32" (BARATTA, 2006, p. 1).

${ }^{205}$ No texto consultado: "la finalidad de una reintegración del condenado em la sociedad no debe ser abandonada, sino que debe ser reinterpretada y reconstruída sobre uma base diferente” (BARATTA, 2006, p. 378).
} 
imagina. Isto, como já se assinalou, redunda em certas falhas de comunicação, até num plano cognitivo elementar" (PARRY, 1967, p. 163). Um termo como reintegração é traiçoeiro e pode fazer até com que uma mesma pessoa o use com significados diferentes, levando ao mesmo prejuízo e força ideológica negativa do termo que pretende substituir: a ressocialização. Tal distúrbio interpretativo é mais provável na medida em que a reintegração já compõe o discurso legitimador e encarcerador que está por traz da ideia de ressocialização.

Será que a aceitação de uma pós-modernidade, onde o próprio Baratta se inclui, não abre espaços para uma ciência que tenha a franqueza de admitir que certas condutas e programas a serem seguidos não podem ser definidos em uma palavra? Afinal, o consenso necessário passa pela aceitação da subjetividade e complexidade de várias questões e, principalmente, da natureza do ser humano. "O consenso é incompatível com os dogmatismos da verdade, e portanto com o fundamentalismo", na expressão do próprio Baratta (1995, p.126). O Século XXI deveria permitir uma prática científica capaz de reconhecer que não pode ser definida por uma palavra.

A crença na ciência e em seus conceitos no meio social tem sido tão diminuta que uma nova palavra, mesmo vindo no sentido de fazer a prisão menos prisão, como supunha ser possível Baratta, não cumpriria o seu papel de caráter científico. Não só pelo descrédito que as construções científicas de gabinete têm, mas principalmente porque esta, a reintegração social, em especial, vem no bojo de uma sanção que nada tem de científica na sua realidade e, além do mais, tal construção mantém uma ambiguidade facilmente preenchida por sentimentos negativos que logo desvirtuariam o seu objeto.

Baratta visava com sua elaboração teórica fugir do discurso destrutivo que é o discurso abolicionista puro e simples, assim como tentou superar a filosofia pós-moderna que, para ele, era auto-reflexiva, fazendo com que seus pensadores abdiquem de se tornarem "protagonistas de um projeto para a sociedade" (BARATTA, 1995, p. 122).

Já falamos da importância de trabalhos que olhem pelo preso e, ainda que reconhecendo a crueldade dos cárceres, discutam formas de torná-lo menos violento. Este trabalho seguiu este objetivo. Contudo, é sempre bom relembrar que a sociedade não se curará do cárcere por intermédio do próprio cárcere. Não se resolverá a cultura prisional do abandono 
no cárcere. Isso é preciso que se diga para que não tomemos conflitos sociopolíticos por conflitos individuais solucionáveis por intermédio do direito.

O cárcere faz parte de uma política de abandono maior e reflete a desigualdade de distribuição de recursos e de poder na sociedade. Baratta sabia melhor do que nós tal situação e ensinou que o "direito contribui para assegurar, reproduzir e ainda legitimar (esta função essencial para o mecanismo de reprodução da realidade social) as relações de desigualdade que caracterizam a nossa sociedade" (2006, p. 96).

Portanto, a reinterpretação do conceito de ressocialização que Baratta defendeu, a mudança de designação para reintegração social, não pode ter esquecido essa realidade. Por isso a reintegração teria que se dar apesar do cárcere. A ênfase no apesar vem do fato de que a reintegração deve se dar em todos os espaços da sociedade. Mas ainda não vemos como o diálogo, o respeito, o valor, o espírito de mudança e a humildade, necessários para tal reintegração, possam ser compactados nessa palavra. A reinterpretação que propõe Baratta não precisaria de um novo signo, mas de muita força e disposição.

Se cientificamente é imprescindível o uso de uma designação para a proposta, bastava que se ficasse simplesmente com a palavra diálogo, pois, embora seja apenas um dos conteúdos da reintegração, nos permite, sempre que pronunciada, avaliar o nível de legitimidade do sistema ${ }^{206}$. Diálogo é uma palavra crítica por natureza, visto que lembra movimento, comunicação constante, pensamento, reflexão que, no meio penitenciário - não temos medo de afirmar - sempre levará à crítica.

E se não pode haver ciência quando seus "pressupostos contradigam a realidade sensível das coisas, sob pena de tornar-se ficção" (TANGERINO, 2011, p. 171), ameaça sob a qual sempre estarão os conteúdos e ideias da reintegração, o diálogo, diferentemente, será sempre possível, pois onde há vida, ainda que massacrada, diminuída ou degradada, há potencialidade para o diálogo, que sempre será a principal forma pacífica de o ser humano superar suas adversidades.

\footnotetext{
${ }^{206}$ Embora Baratta não se refira especificamente à palavra diálogo quando trata da reintegração social, deixa claro que o "conceito de reintegração social requer a abertura de um processo de comunicação e interação entre o cárcere e a sociedade" (2006, p. 380). No original: "el concepto de reintegración social requiere la apertura de un proceso de comunicación e interacción entre el cárcel y sociedad".
} 
No nosso modesto modo de ver, a prisão, como prática política que é, não suporta mais um período de legitimação. O risco não é válido. Recentemente superados, mas ainda com evidentes resquícios na prática judicial e penitenciária, os pressupostos positivistas demoraram anos servindo de base para a cultura encarceradora. Depois, com o reforço da ideia de ressocialização, mais alguns anos a prisão ganhou como prática legítima, a despeito de toda a incoerência com que conviveu. Portanto, a construção de um novo ideal no seio da pena privativa de liberdade, ainda que bem intencionado e no caminho da abolição desta, pode servir como oxigênio para uma sobrevida de algo que não é útil nem para a pessoa punida nem para a sociedade.

\subsection{0 cárcere e o diálogo possível}

Como a ressocialização surgiu na dogmática penal, pensada como instrumento de humanização do sistema penitenciário, o diálogo proposto por Baratta igualmente vem a favor da dignidade da pessoa humana. Até que ponto é possível este diálogo em um meio tão destruído quanto esse da punição, onde sofrem os que punem e os que são punidos, não se sabe, mas se pode perceber que a potencialidade do diálogo está sempre presente.

É em nome da dignidade da pessoa humana, constatada a existência real de pessoas presas, que não se pode abandonar a ideia dessa comunicação recíproca na qual se constitui o diálogo. Exploraremos, então, as possibilidades e as impossibilidades nesse campo, ainda que seja para concluir mais uma vez que a prisão é puro aniquilamento e que o diálogo acaba abafado pelas paredes frias e mudas da prisão.

\subsubsection{O pessoal penitenciário}

Afastada das considerações tidas como científicas sobre a prisão está a prática do pessoal penitenciário, do voluntariado, enfim, de todos que circulam, frequentam ou convivem com o dia a dia do sistema penitenciário. Por mais que tragam as suas preconcepções científicas, estas pessoas, no convívio com cárcere e o encarcerado, logo percebem que elas, as concepções científicas anteriores, não serão de muita utilidade. 
Neste campo o ideal de reintegração, na forma como acima referido sobre o posicionamento de Alvino Augusto de Sá (2010), tem mais possibilidades. Por óbvio o diálogo, o reconhecimento recíproco entre seres humanos, tem mais espaço na interação entre iguais do que entre uma instituição austera e antidemocrática, como o judiciário, e a população, especialmente a população penitenciária.

Pode parecer estranho estarmos excluindo o Poder Judiciário da possibilidade de diálogo inerente à prática penitenciária, mas a comunicação do judiciário com a sociedade tem sido sempre de cima para baixo, praticamente um monólogo, muito distante de qualquer coisa que se possa considerar diálogo. A estrutura interna desse poder, hierarquizada, não abre muito espaço para iniciativas de mudanças. O seu principal instrumento de trabalho é a lei que tem tido a grave função de encobrir a realidade e, sem uma representação sincera do que seja real, a comunicação fica extremamente dificultada.

No campo penitenciário podemos ter uma figura estereotipada do judiciário naquele juiz que chega na penitenciária de terno e gravata, com coletes à prova de balas, escoltado por policiais armados, e fala obviamente com medo, quando fala, com os presos, seres humanos recolhidos naquele estabelecimento penal. O diálogo, em tal situação, é algo improvável, para não dizer impossível. O juiz de Calamandrei, por exemplo, que entra em "férias mentais" (1985, p. 71) quando o advogado fala, quando o preso falar, nunca irá ouvi-lo. Quase cem anos depois do célebre italiano, Alexandra Szafir encontra "juízes que acabam confundindo a autoridade que o cargo lhes confere com uma suposta superioridade sobre os demais mortais. Quando isso acontece, os julgadores já se afastaram tanto de sua condição humana que é inútil esperar deles um mínimo de bom senso" (2010, p. 39).

Não é à toa que estivemos defendendo o limitado princípio da legalidade na prática jurisdicional, porque a Constituição Federal, a Lei de Execução Penal e até o Código Penal, nas suas simples literalidades, estão mais próximos de reconhecer o preso como ser humano, do que a interpretação que o judiciário tem dado a essas legislações. Note-se que o relacionamento de uma pessoa com o juiz que a está julgando é essencial "para que essa pessoa se sinta justiçada ou não. O que significa dizer que o comportamento das autoridades vai ser um fator fundamental na construção do sentimento de justiça ou injustiça da pessoa que está em questão" (SPADONI, 2009, p. 38). 
A questão não é este ou aquele juiz especificamente, porque logicamente há os que superam ou resistem à barreira institucional e se aproximam da sociedade como iguais. Ocorre que, para tanto, o ser humano juiz precisa de uma constante reflexão - o que a burocracia de sua atividade muitas vezes não permite. O ser humano juiz passa, desde o processo de sua seleção, por um rigoroso método de perda de identidade "mediante uma paciente internalização de sinais de falso poder: solenidades, tratamentos monárquicos, placas especiais ou automóveis com insígnias, saudações militarizadas” (ZAFFARONI, 1991, p. 141).

Todavia, outro grande problema é que nem mesmo a interação entre o pessoal penitenciário estritamente falando ${ }^{207}$ e os presos é realizada entre iguais. Há uma grade no meio. E essa grade é intransponível, porque o ser humano, como todo animal, não nasceu para estar enjaulado. Um diálogo em situação de cárcere é e sempre será algo precário.

Então se queremos falar de um cárcere menos prejudicial, porque se há cárceres piores que os outros (BARATTA, 2006) sempre poderemos estar pensando na possibilidade de reformar o cárcere, esta reforma só pode passar pelas mãos de quem convive com o cárcere e, de preferência, pela sociedade em geral, que deveria presenciar e conhecer melhor a sua própria forma de punir. Aliás, só assim poderíamos imaginar uma mudança de postura inclusive do judiciário, pois seus integrantes não deixam de ser selecionados periodicamente, ainda que elitizadamente, do seio da sociedade.

A reforma do cárcere no sentido de uma interação com a comunidade é uma reforma permanente que sempre terá altos e baixos. Será constantemente composta de avanços e retrocessos. De encontros e abandonos também. É uma reforma que nunca terminará enquanto houver cárcere. Mas este problema não é desta ou daquela concepção, é do próprio cárcere que, por ser irracional, nunca permitirá avanços que não sejam no caminho de sua extinção.

Outra grande dificuldade de se alterar o cárcere, ou a concepção social que se tem sobre ele, é o fato de que poucas pessoas se debruçam sobre o estudo ou sobre o combate dessa forma de punir por muito tempo. Não só porque os problemas sociais são muitos e estão

\footnotetext{
${ }^{207}$ Passaremos a tratar como pessoal penitenciário apenas os agentes, técnicos e demais funcionários que atuam diretamente como o sistema prisional, sem deixar de reconhecer que o sistema prisional faz parte de um complexo sistema punitivo onde diversos agentes têm direta influência sobre o meio prisional, embora ainda assim não se vejam como pessoal penitenciário.
} 
sempre a nos chamar a atenção, sendo o cárcere somente mais uma dessas mazelas e consequência da maioria delas, mas as pessoas se afastam do estudo do cárcere também porque esgotam seus argumentos na repetição do óbvio. Há diversos estudos sobre o cárcere que são fato excepcional na vida de um acadêmico ou estudioso das ciências sociais, este que logo passa para outro tema, deixando o cárcere no seu lugar, ainda puro abandono e violência.

O pessoal penitenciário, as pessoas envolvidas diretamente com o cárcere, normalmente assim estão por questões puramente profissionais, que às vezes até lhes foge do controle. Ou foi uma designação administrativa, um concurso público que fortuitamente lhes levou a trabalhar com o sistema penitenciário. Dificilmente alguém procura o cárcere, por que nele não há nada de agradável. O voluntariado que visita hospitais, prisões e asilos de nossa sociedade é escasso e, mesmo assim, extremamente limitado à sua concepção filantrópica, o que dificulta a ação e a postura necessárias para a reforma do sistema.

Não obstante, qualquer mudança possível só pode ter início com a colaboração dos profissionais que trabalham com o cárcere. Por mais que sejam pessoas de passagem e estejam igualmente atingidas pelo ambiente prisional, psicologicamente afetadas pela violência e pela pressão do ódio e da tristeza que estão em toda parte, são as verdadeiramente indicadas a abrir as portas para qualquer provável mudança. A começar pelo fato de que, como se diz na linguagem dos presos, estão com a chave da cadeia. Chave não tanto para deixar sair o preso fisicamente falando, mas para deixar entrar a sociedade ou para deixar sair a imagem verdadeira do que é estar preso, sem sensacionalismos, sem espetáculos. Chave também para deixar sair o que tiver de humano nas pessoas que lá estão massacradas, para que haja algum contato saudável com o meio social e para que este contato diminua estigmas e rancores dos lados de fora e de dentro.

Quando falamos sobre a importância, entre os profissionais da CTC, da interdisciplinaridade na esfera penitenciária (3.6.1), citamos inúmeros problemas e dificuldades para sua implementação. Contudo, quando se fala em diálogo o que se está ambicionando é algo bem maior: a transdisciplinaridade. Neste conceito não basta que o pessoal penitenciário esteja aberto para sugestões e ideias entre eles próprios, seus conhecimentos e suas ciências, faz-se necessário uma revisão de conceitos, da história, dos valores e da ética de cada um, não para negá-los, mas para "reconhecer-lhes os limites, os 
questionamentos, a relatividade, no sentido de repensá-los par a par com o contraditório oferecido por outros valores e outras formas de pensar a ética, no sentido de repensá-los a luz de outras histórias, de outras subjetividades" (SÁ, 2010, p. 184).

Em suma, o preso precisa ser verdadeiramente ouvido, precisa participar de qualquer transformação que se pretenda operar por iniciativa dos profissionais penitenciários, por que ele precisa participar da organização de sua própria vida, liberdade sem a qual o peso das paredes e grades do cárcere aumenta.

Pode-se contra-argumentar que o preso já comanda as penitenciárias e cadeias, ou seja, ele já organiza a própria vida. Mas isso ocorre por intermédio de lideranças negativas, com interesses espúrios, portanto de forma arbitrária e alienada dentro do próprio cárcere, não interessando que esse arbítrio seja exercido por alguns dos próprios presos. Isso ocorre também pela omissão, muitas vezes oriunda do desânimo que abate as pessoas que deviam evitar tal situação.

Alessandro Baratta faz uma proposta de trabalho em conjunto, onde haveria reciprocidade e revezamento de papeis entre o pessoal penitenciário e os presos, denominada "reciprocidad y rotación de los roles", resumindo-a da seguinte forma:

Desenvolver em todas as suas consequências o princípio da simetria nas relações entre usuário e operador é a premissa para criar condições aptas para a reciprocidade e revezamento de papeis. Reciprocidade de papeis significa que a interação entre seus portadores se transforma de funções institucionais em oportunidade de autêntica comunicação, de aprendizagem recíproca e, portanto, também de alívio da perturbação e da liberação das frequentes síndromes de frustração. O revezamento de papéis significa valorar, além das competências profissionais e das estruturas hierárquicas da organização, as competências e funções de cada ator-preso, operador, administrador, para a solução coletiva de conflitos e perturbações, para a construção dos programas e serviços e suas realizações, para as decisões em todos os níveis. Os presos também podem desempenhar papéis nos serviços do interior e do exterior do cárcere $^{208}(2006$, p. 386).

\footnotetext{
${ }^{208}$ Tradução livre de: "Desarrollar en todas sus consecuencias el principio de la simetría en las relaciones entre los roles de usuario y operador es la premisa para crear condiciones aptas para la reciprocidad y la rotación de los roles. Reciprocidad de los roles significa que la interacción entre sus portadores se transforma de funciones institucionales en oportunidad de auténtica comunicación, de aprendizaje recíproco y por tanto, también de alivio de la perturbación y de liberación de los frecuentes síndromes de frustración. La rotación de los roles significa valorar, más allá de las competencias profesionales y de las estructuras jerárquicas de la organización, las competencias y los aportes de cada actor-detenido, operador, administrador, a la solución colectiva de los conflictos y perturbaciones, a la construcción de los programas y de los servicios y a su realización, a las decisiones en todos los niveles. Los detenidos también pueden desempeñar roles en los servicios en el interior y
} 
O professor italiano informa, sem exemplificar, que há experiência desse tipo na Itália. Ao que nos parece, a proposta é bem parecida com o que ocorre nas denominadas APAC's, experiência brasileira que se iniciou em 1974, quando Sílvio Marques Neto, juiz da execução penal com jurisdição sobre a Comarca de Humaitá, São Paulo, entregou para a Associação de Proteção e Assistência aos Condenados - APAC, a administração do estabelecimento penal de Humaitá, ocasião em que foram dispensadas a figura do policial e do carcereiro. Experiência exitosa que tem servido de exemplo e é seguido inclusive fora do Brasil (OTTOBONI, 2001).

A lembrança do método APAC no meio de tanto caos, como se apresenta o sistema penitenciário brasileiro, é indício de que há possibilidade de se fazer algo para a melhoria do sistema. No entanto, são exemplos raros. A única grande diferença existente entre a proposta de Baratta e as APAC's é o fato de que estas são na maioria das vezes oriundas de iniciativa do voluntariado, enquanto a proposta do criminólogo era de que a mudança de postura partisse do próprio pessoal penitenciário.

Ocorre que, de uma forma ou de outra, para a transdisciplinaridade e, em consequência, para o diálogo, é necessária uma maior liberdade. O pessoal penitenciário também não é livre, seja pela burocracia, que emperra suas atividades, seja pelas precárias condições de trabalho ou, pela própria lei que impõe regras e condutas baseadas no ideal ressocializador/disciplinador. O administrador, o psicólogo, o assistente social, enfim, todos os que trabalham com o preso, acabam também igualmente tolhidos.

Talvez seja mesmo de utopia que se fala:

Ora, apesar de todas as dificuldades e obstáculos, às vezes programaticamente oferecidos, é possível (deve-se ter a esperança, ainda que um tanto utópica) implantar medidas no cárcere no sentido de se preservar, na contramão do cárcere, a pessoa do preso, a sua fala, o seu discurso, no sentido dele ser ouvido, compreendido, e de ser apoiado para se emancipar como pessoa (SÁ, 2011, p. 414) (Grifo no original).

Mas há uma razão para ainda acreditarmos que por intermédio do pessoal penitenciário se pode conseguir algo. Quando eles forem capazes de perceber que o contato com o preso gera conhecimento - e são eles que possuem esse contato diário - podendo de alguma forma

exterior de la cárcel. En este último caso, la reciprocidad de los roles se extiende fuera de los muros de la cárcel" (BARATTA, 2006, p. 386). 
se afastar de seus dogmas, suas preconcepções, para fazer desse conhecimento um gerador de ideias e soluções, o diálogo pode ser possível.

Luís Cláudio Figueiredo lembra, citando Heidegger, que a verdadeira experiência transforma, "comporta um momento de encontro, de negação, de transformação. Ou seja, experimentar é deixar-se fazer outro no encontro com o outro. Em outras palavras: só há experiência onde há diferença e onde novas diferenças são engendradas” (2009, p. 20). É o que não falta ao pessoal penitenciário, bastando que a potencialidade do encontro e da experiência no sistema seja percebida.

Certa dose de humildade é ingrediente da transdisciplinaridade ${ }^{209}$ e é imprescindível para ver naquela pessoa mal vestida, suja, algemada, com um vocabulário diferente, arrogante, defensivamente agressivo, que chega ao estabelecimento penal, uma pessoa com quem se pode aprender. Não se pode esperar do preso a compreensão necessária para o início do diálogo. Àquela aparente insolência não se pode contrapor aborrecimento. A linguagem possível no meio carcerário passa pela superação desse primeiro difícil contato. $\mathrm{O}$ medo de ambos os lados deve ser superado.

A violência também é uma linguagem, por mais rudimentar que seja, por mais que seja orientada para fazer o outro calar. E é esta linguagem muitas vezes a única que o preso conhece $^{210}$. Falarei da situação do preso especificamente logo a seguir, mas o profissional penitenciário precisa não temer tal linguagem para que o diálogo comece. Um olhar, um gesto, uma palavra mais forte, o som da voz, nada disso pode fazer o interlocutor temer. São defesas do preso que precisam ser quebradas com a confiança. Fazer-se confiável é o primeiro passo.

O aspecto medo deve ser superado não só em relação ao contato pessoal, mas de forma mais determinante deve ser essa superação para que haja ciência, para que o conhecimento do homem sobre ele mesmo seja possível e para que o conhecimento não seja propriedade de apenas alguns:

\footnotetext{
209 Para Ubiratan D'Ambrosio a "transdisciplinaridade repousa sobre uma atitude aberta, de respeito mútuo e mesmo de humildade com relação a mitos, religiões e sistemas de explicações e de conhecimentos, rejeitando qualquer tipo de arrogância ou prepotência" (1997, p.80).

${ }^{210}$ Diz Fernández-Armesto que "pesquisadores de inteligência artificial relataram que mais de 50 por cento do sentido de uma comunicação não são transmitidos pelas palavras usadas ou mesmo pelo tom da voz, mas sim pela linguagem corporal e expressão facial" (2000, p. 43).
} 
Se, porém, o pensamento deve tornar-se propriedade de muitos e não privilégio de alguns, é mister livrarmo-nos do medo. É o medo que contém os homens - medo para evitar que suas crenças mais caras se mostrem ilusórias; que as instituições, em função das quais vivem, se mostrem nocivas, que eles próprios se mostrem menos dignos de respeito do que jamais se supuseram (RUSSELL, 1958, p. 120).

Por isso, desnecessário frisar que o funcionário, ele também deverá ser humano nessa relação, e deverá ser o primeiro a se mostrar assim. Em outras palavras, não poderá escorar-se no aspecto público de sua função. A subdivisão da psique em público e privado deve, por isso, ser superada. Tal se dá por duas evidentes e principais razões: a primeira pelo fato de que o preso não confiará em nenhum representante da burocracia estatal; a segunda pelo fato de que a postura funcional fria e calculista vem igualmente carregada de violência. Deve-se evitar o distanciamento emocional, não daquela emoção do senso comum, mecanizada, mas daquela derivada do contato, aquela que é a própria comunicação, esta deve ser facilitada, assumindose todos os riscos inerentes a essa conduta.

É um diálogo que deverá durar e ultrapassar as funções burocraticamente definidas. Para que haja alguma espécie de transdisciplinaridade, o grupo que forma a instituição deve promover a sua própria subjetividade. Relevante a advertência de Guattari de que "a máquina do Estado, a máquina de repressão produzem a antiprodução, isto é, significantes que servem para entravar e interditar a emergência de todo o processo subjetivo de grupo" (2004, p. 212) (Grifo no original). E o nascimento dessa subjetividade só se dará com o reconhecimento e o respeito dos sentimentos e emoções de cada um, tarefa dificílima tanto mais no meio penitenciário onde a antiprodução é enorme.

Não obstante, e resultado de toda a antiprodução, a política de construção de grandes estabelecimentos penais, que segue orientação norte-americana ${ }^{211}$, vai de encontro com a possibilidade da existência de um grupo uniforme nas instituições prisionais. Pequenas cidades, locais onde o sentido de comunidade é maior e que poderiam ter uma verdadeira

\footnotetext{
${ }^{211}$ Michael J. Lynch fala da cultura norte-americana do "bigger is better" que influencia a população a achar que tudo que é maior é melhor. Assim, os americanos consomem carros maiores mesmo sabendo que são mais poluentes e podem ser menos seguros, consomem aparelhos de televisão grandes para assistirem grandes jogos, desejam grandes casas como símbolo de status, adoram grandes redes de restaurantes, grandes lojas, possuem grandes sonhos e têm grandes dívidas. "Os americanos também têm um grande nível de criminalidade. E, mais do que isso, eles igualmente possuem o maior sistema prisional do mundo" (Americans also have a big crime rate. More than that, they also have the world's biggest correctional system). (2007, p. 3).
} 
integração com as pessoas que lá cumprem pena, vêem seus presos serem transferidos para grandes centros, grandes cadeias das capitais.

Nesses centros e nessas grandes prisões, não só a relação entre presos e funcionários se torna dificultada, mas qualquer pretensa participação da sociedade também. Penitenciárias que são verdadeiros monstros de pedra encravados na cidade e que ainda levam o resquício da arquitetura austera, princípio herdado do ideal de reforma do ser humano pela disciplina, afastam, assustam a comunidade, ao invés de estimular a interação. A ojeriza por parte da sociedade contra esses monstros é tamanha que só a ideia de se construir um perto de um conjunto de casas ou de um bairro já gera protestos. Trata-se da síndrome de $\mathrm{Nimby}^{212}$, termo que serve para descrever a "reação de residentes hostis a planos de construção que ameacem ou desvalorizem sua vizinhança imediata" (COMBESSIE, 2004, p. 146). Construídos, esses monstros não irão produzir simpatia facilmente.

O município, esfera administrativa de poder mais próxima da sociedade, não exerce nenhuma função na execução da pena, o que só agrava a política centralizadora dos grandes estabelecimentos penais. O verdadeiro local para onde o preso vai voltar, a sua cidade, representada pela municipalidade, não participa do processo de execução da pena.

As características desumanas do sistema penitenciário, seja a das construções frias e massacrantes dos edifícios, seja a da desconsideração do preso como ser humano, são antiproduções. Vencer tais obstáculos seria imprescindível, mas da mesma forma que qualquer avanço da prática jurisdicional passa pelo respeito estrito à lei, ou seja, da mesma forma que a observância do princípio da legalidade é pressuposto mínimo para o avanço na interpretação judicial que se pretende seja progressista, o respeito a condições básicas de sobrevivência é condição primordial para o início de qualquer diálogo. Não há como pensar, falar, sentir ou ouvir, com fome, com sede, com dor ou sem dormir.

A hipótese de diálogo que Alessandro Baratta denominou de reintegração social no contexto em que escrevia, das prisões da Itália e da Alemanha, onde o abandono científico e psicológico do preso é similar ao nosso, fica mais distante se consideramos a situação material

212 "Nimby é o anacrônimo de 'Not in my back yard' [não no meu quintal] (...) A forma mais extrema de 'nimbismo' é conhecida como Banana (Build absolutely nothing anywhere near anybody [Não construa absolutamente nada em lugar nenhum perto de ninguém)" (COMBESSIE, 2004, p. 146). 
do preso brasileiro, onde há presos necessitando de assistência básica. Presos que têm que dormir em turnos por falta de espaço; "presos doentes, precisando de atendimento dentário (chegam a improvisar formas artesanais e dolorosas de extração) ou com feridas expostas, [que] ficam a um canto, duplamente segregados porque rejeitados pelos companheiros que temem contrair infecção" (SOUZA, 2006, p. 178); presos que ficam semanas sem ver a luz do sol; presos que só sentem gosto na comida no fim de semana, quando esta é trazida por familiares; presos torturados e extorquidos diariamente; presos que têm que matar ou virar soldados para sobreviver; presos sem assistência jurídica, que não têm qualquer informação sobre as possibilidades de suas liberdades; enfim, são condições que devem ficar registradas para contrastar com a possibilidade de diálogo no Brasil.

Até por tais condições a filantropia fala mais alto nas pessoas que conhecem a realidade carcerária e possuem o mínimo de sentimento. E quando a filantropia se sobressai sobre a reflexão a respeito das condições e relações sociais que levam a tal situação, o avanço é dificultado. O filantropo não se vê como responsável, fazendo parte da mesma sociedade que proporcionou esse caos, mas sim como bálsamo social que acaba não percebendo, na sua ação, um potencial crítico.

Por isso enfatizamos primeiramente o papel do pessoal penitenciário, porque este sofre muitas das mazelas que o próprio preso está sofrendo, sendo, então, o mais indicado para falar primeiro, escancarar as portas do cárcere para a sociedade, nem que seja em benefício próprio, para livrá-los da prisão que também os encarceriza.

As condições prévias para qualquer diálogo, onde o preso possa ser ouvido e participar, não no seu processo de ressocialização, nem no seu processo de reintegração (até porque dentro da concepção democrática que se quer dar à reintegração, a ideia de processo fica esvaziada), mas durante o tempo em que estiver recluso, durante o tempo em que estiver sofrendo a pena aplicada, as condições prévias para esse diálogo estão inteiramente nas mãos do pessoal penitenciário. Não é por outro motivo que Alvino Sá achou oportuno e se permitiu "fazer uma ponte entre o sistema penal e a Criminologia (Clínica)" (2010, p. 150), utilizandose da ideia de vulnerabilidade de Zaffaroni, com o fim de, combatendo-se a deteriorização causada pelo sistema penal como um todo e pelo cárcere especificamente, seguir no caminho da proposta de diálogo. 
Todavia, esta nova criminologia ou criminologia da vulnerabilidade não será possível se ela não se permitir uma reflexão sobre a sua própria vulnerabilidade. Em outras palavras, essa mudança de paradigma, alterando-se o perfil da equipe que trabalha com o preso e a referência de estudo, retirando-se o foco do crime e fixando-o na vulnerabilidade presente no meio social, não será possível sem que se observe a vulnerabilidade dessa própria equipe. Zaffaroni previu perfeitamente isso e denominou igualmente de vulnerabilidade a situação dos policias, agentes penitenciários e até juízes que trabalham no sistema punitivo, considerando que, diante da "policização, a burocratização e a criminalização, o sistema penal é um complexo aparelho de deteriorização regressiva humana que condiciona falsas identidades e papéis negativos" e, não obstante, "poucas vezes é adequadamente observada a situação de extrema vulnerabilidade na qual se colocam essas pessoas" (1999, p. 143).

Observação que não fugiu à análise de Baratta quando expressa que "a saúde mental dos operadores não está menos ameaçada do que a dos presos, em razão da alienação geral que caracteriza as relações entre pessoas e entre papeis do mundo carcerário" ${ }^{213}$ (2006, p. 389). Assim, o que torna o tratamento dessa vulnerabilidade do pessoal penitenciário mais difícil é justamente o fato de que eles próprios não se percebem vulneráveis, nem muito menos atingidos pelo cárcere.

As barreiras materiais, ideológicas e políticas para que uma criminologia da vulnerabilidade seja completa e atinja os demais integrantes do sistema penal são óbvias. Um estudioso que se aventure a pesquisar a vulnerabilidade desse pessoal, principalmente de juízes e promotores, pode ser acusado de desrespeito, invasão de privacidade e até desacato. Quando um juiz entra em depressão logo é encontrada uma resposta apolítica para o problema: o excesso de trabalho. Pesquisas neste campo, por exemplo, se concentram no estudo dos juízes que estão com depressão ${ }^{214}$, quando, na verdade, deveria ser estudado o juiz que não sente depressão diante da ruína em que se encontra o meio social e das misérias que se apresentam para serem sopesadas.

\footnotetext{
213 "La salud mental de los operadores no está menos amenazada que la de los detenidos, por la alienación general que caracteriza las relaciones entre personas y entre roles del mundo carcelario" (Baratta, 2006, p. 389).

${ }^{214}$ Em pesquisa realizada em parceria com a faculdade de medicina da Universidade Federal de Minas Gerais, a Associação Naciona dos Magistrados da Justiça do Trabalho encontrou diagnosticados com depressão $40 \%$ dos juízes trabalhistas, $17 \%$ tomando remédio controlado. (disponível em: <www.amatra9.org.br/>. Acesso em: 04 jul 2011).
} 
O profissional que trabalha com o sistema penal e nada sente é justamente o grande suspeito. E estudá-lo será praticamente impossível, porque esta frieza é inerente ao sistema e se confunde com força, segurança e experiência na lide diária. O legalista, que de cumpridor da lei (e muito menos da Constituição) não tem nada, é o protótipo da pessoa fria frente à realidade do sistema. A vulnerabilidade destes profissionais, no sentido do prejuízo que sofrem sobre suas personalidades e sobre a condição de seres humanos que são, por sua intocabilidade e resistência, chega a ser mais grave do que a dos próprios presos: "a resistência, no entanto, tenderá a ser maior entre os policiais, profissionais penitenciários e juízes, do que entre os próprios criminalizados, pois os primeiros tenderão a identificar como méritos profissionais os efeitos deteriorantes que o sistema penal lhes acarreta" (SÁ, 2011, p. 497).

Quanto ao agente penitenciário, como o policial, por exemplo, geralmente selecionado de idêntico grupo social, tende a ver o preso como uma pálida e desconfortante figura de si mesmo. O criminoso é aquele que não aceitou as duras regras do sistema social, que aparentemente teve as mesmas oportunidades, mas delinquiu, portanto um fraco que procurou o caminho mais fácil do crime. O sentimento de justiça aqui é bastante raso e o agente se vê injustiçado por receber aquele parco salário, sofrer as péssimas condições de trabalho a que é submetido, com escassas chances de progressão na carreira, ou seja, no máximo sobrevivendo, enquanto o preso, da mesma forma, no máximo sobrevive.

Possuímos todos uma visão militarizada da sociedade, onde em tudo tem ou há de ter hierarquia. Desde a família, passando pelas instituições escolares e no trabalho, o posto hierárquico daquele que manda sempre existiu. A obediência é uma atitude de submissão burocratizada pelo sistema e o preso, seja porque quebrou as regras desse sistema ou porque é visto no mais baixo grau dessa hierarquia, não pode ser percebido ou tratado como igual.

A privatização do sistema penitenciário e/ou a terceirização de determinados serviços, sempre atingindo o setor de segurança, vem no sentido de agravamento dessa vulnerabilidade do pessoal penitenciário, visto que além da precariedade em que se veem, os agentes e demais funcionários do sistema perdem inclusive a estabilidade trabalhista. A segurança no emprego para quem trabalha em um setor tão promíscuo como o sistema penitenciário seria essencial 
para o mínimo de auto-estima e para a superação dos medos naturais neste meio que, como se disse, é superação fundamental para que se trave qualquer diálogo.

Por fim, como se observa, a vulnerabilidade do pessoal penitenciário, assim como a do preso, não é tratável individualmente. Carece de medidas amplas que ultrapassam - e é primordial que ultrapassem - a superestrutura estatal. Só a conscientização acerca de seus lugares na sociedade, acreditando-se ser capaz de alguma alteração estrutural, poderá trazer a possibilidade de mudança. Diálogo, importante ressaltar, não se tem sem consciência.

\subsubsection{A participação da comunidade e a experiência do GDUCC}

Todas as circunstâncias trazidas até aqui sobre o sistema penitenciário, a ciência penal construída sobre bases irreais, a interpretação da lei na forma de dupla ou múltipla punição, a destruição do meio penitenciário acompanhada pela vulnerabilidade dos seus atores, presos e agentes, são observações que nos levam a, pessoalmente, não acreditamos que a mudança do sistema saia do seio do próprio sistema.

Escrevemos estas últimas linhas visitando semanalmente o cárcere e nossa convicção só aumentou. $\mathrm{O}$ cárcere nunca poderá ser descrito por palavras e a ciência penal se aproveita dessa situação. Estuda, analisa e descreve a prisão como objeto científico quando, na realidade, o faz só porque está distante e pode selecionar questões, problematizar alguma contingência. $\mathrm{O}$ que escrevemos agora mesmo passa ao largo de intermináveis problemas que nunca serão suficientemente contextualizados. Não adianta dizer que o cheiro da prisão é diferente e que em determinadas ocasiões o preso perde o direito até ao ar para respirar. Não adianta tentar descrever a sujeira ou o clima hostil de determinado lugar, porque nada, a não ser o próprio lugar, é capaz de transmitir tais percepções, tais sentimentos.

Denunciar tais condições em mais um trabalho, aliás, já é atitude vulgar e pode seguir a tendência contrária aumentando o menosprezo ou a frieza para com o preso. Por isso, mesmo trazendo inúmeras questões negativas sobre o cárcere, o fizemos dentro de uma proposta otimista, a de reintegração de Alessandro Baratta. Fazer do cárcere algo menos mal, porque há cárcere piores do que outros, é um argumento forte, embora aparente ares legitimadores do cárcere. 
Mas há outro lado da proposta do professor italiano que parece ser mais sedutor e faz sentido com o que acreditamos. Trata-se da participação da comunidade no processo de comunicação, interação. Ainda que esta comunicação entre sociedade e preso, passando pela interação com o sistema punitivo como um todo, seja recheada de diversos distúrbios, ainda assim percebemos vantagens na proposta.

Desde já é bom lembrar que a participação da comunidade na execução da pena não é uma proposição moderna. A LEP prevê o Conselho da Comunidade a ser formado pelo juiz da execução (art. 80), mas as orientações de John Howard já vinham com a indicação de que os juízes encontrassem pessoas para efetivarem fiscalizações rotineiras nas prisões, tarefa nem sempre fácil, achar "um homem generoso o suficiente para realizar esse importante serviço" 215 (1777, p. 67). Ocorre que a história da prisão é a história de seu constante afastamento da comunidade, pois, desde os primeiros cárceres, que precisavam ser moralizados justamente porque havia certa promiscuidade reforçada pelo contato com o mundo exterior, até hoje, o que se viu foi a sociedade cada vez mais distante do preso $^{216}$.

Então, não importa a posição filosófica ou científica daquele que escrevia ou legislava sobre a prisão, sempre houve o bom senso de se pensar que a comunidade podia ou devia participar de alguma forma, seja fiscalizando, seja ajudando ou simplesmente se fazendo presente nos cárceres. Mas a prática política, a política penal, seguiu caminho oposto, dificultando a entrada dos cidadãos nas prisões, construindo cárceres cada vez mais distantes da comunidade, transferindo presos ou mesmo escondendo presos em celas escuras. Nesta questão da participação comunitária fica bem claro o paradoxo que é a prisão: uma instituição fechada que precisa deixar entrar quem está fora; uma instituição que não pode deixar ninguém sair, mas deve deixar as portas abertas para a comunidade entrar.

O que temos, como bem coloca Shecaira, são dois polos opostos. A repressão, por intermédio da prisão, e a participação comunitária. Quando se exacerba uma, se afasta da

\footnotetext{
${ }^{215}$ No original "one man generous enough to undertake this important service" (HOWARD, 177, p. 67)

${ }^{216}$ Interessante notar que no período colonial brasileiro os presos eram recolhidos em Casas de Câmara e Cadeia, localizadas nos centros das cidades, onde normalmente as celas eram no andar térreo e a Câmara dos Vereadores no andar de cima. Nestes estabelecimentos os presos ficavam expostos e ao mesmo tempo em que eram vistos, eram também ajudados pelas pessoas que passavam na rua e os viam pelas grades (FERREIRA; VALOIS, 2010).
} 
outra, ou "sempre que nos distanciamos da repressão, para o controle social da nossa sociedade, nos acercamos da Democracia" (1997, p. 173).

Só o fato de se regular a participação comunitária por lei, sem uma abertura ampla da instituição prisão para o debate e a crítica da sociedade, já demonstra que o poder público, com a concessão da participação da comunidade busca também certa dose de legitimidade. $\mathrm{O}$ que se faz, no caso de tais disposições legais, é selecionar a comunidade que pode entrar no estabelecimento penal. Vê-se então que o poder público não confia na sua comunidade, considera-a criminógena e, não se contentando em dizer quem pode sair da prisão, tem ainda que determinar quem ali pode entrar. Por isso que muitas vezes a prisão parece distante do conceito de instituição pública e se assemelha mais a uma instituição de sequestro, o qual tem demonstrado possuir péssimos cativeiros e onde só têm entrado cúmplices.

Não nos aprofundaremos no tema, mas o uso do termo comunidade, por si só, já demonstra certo idealismo legitimador por parte do poder público, visto que congrega vários conteúdos positivos, ligados à solidariedade e a objetivos comuns, valores cada vez mais escassos em nossa sociedade. Como ressalta Boaventura Santos, há "dificuldade em definir a comunidade enquanto arena de solidariedades concretas", ideia "varrida do pensamento liberal, que reduziu toda a complexidade social à dicotomia Estado/sociedade civil” (1997, p. 25). Assim, a comunidade, como conjunto de complexidades individuais que coabitam pacificamente em prol de um bem comum, favorecendo a solidariedade, foi reduzida à entidade sociedade civil, que é mais um conjunto de indivíduos separados entre si por interesses egoístas, do que representação de um conteúdo comunitário.

E, na letra da lei, cabe ao juiz da execução selecionar e compor o Conselho da Comunidade (art. 66, IX, da LEP), o qual será integrado por representantes da OAB, da Defensoria Pública, da Delegacia Seccional do Conselho Nacional de Assistentes Sociais, e de associação comercial ou industrial (art. 80 da LEP). Ora, de início já se observa que a participação da comunidade está atrelada à iniciativa do juiz da execução penal, portanto limitada previamente.

É bem verdade que a lei diz caber ao juiz compor e instalar o Conselho da Comunidade (art. 66, IX, da LEP), não lhe sendo, entretanto, possível vedar ou obstaculizar a 
criação do conselho. Todavia, temos visto casos em que o juiz tem criado empecilhos para o seu funcionamento ou até extinguindo conselhos em atividade ${ }^{217}$ sob diversos pretextos, quando, se consciente de sua função social e política, o magistrado deveria inclusive ser membro, participar efetivamente das atividades desse conselho em nível de igualdade com os demais integrantes. A postura de autoridade pode facilmente confundir e levar ao autoritarismo, circunstância evidentemente prejudicial à ação solidária e participativa que deve estar na gênese da interação comunidade-cárcere.

Uma segunda observação sobre a composição do conselho, como quer a lei, é a de que o mesmo nada terá de representação, ainda que seja do ideal de comunidade. As entidades representativas previstas legalmente estão distantes da comunidade de onde o preso veio e para onde o preso voltará. Esta comunidade, a do preso, é mantida distante dos estabelecimentos penais porque é nela que o estado-polícia identifica o foco de perigo. Sabe-se que a mira do direito penal está apontada contra os, portanto, não vai ser por intermédio do direito penal que essa população de excluídos e ameaçados irá se aproximar. Nenhum instrumento de violência atrai para si o seu próprio alvo.

Por isso as revistas vexatórias, os locais de visita inapropriados e os diversos obstáculos que o preso encontra para ter contato com os seus ou, melhor dizendo, que os seus familiares encontram para terem contato com o preso. Mister ressaltar, todavia, que potencial para esta aproximação com a comunidade existe, porque é conhecido o esforço sobre-humano que os familiares de encarcerados fazem para se encontrarem com seus entes presos ${ }^{218}$.

Diante desse quadro fica inviável imaginar o nascimento de uma postura crítica que seja construtiva dentro do sistema penal, por intermédio da comunidade. A verdadeira comunidade, a que interessa ao preso e a que por ele se interessa, quando lhe sobra espaço e fôlego para a crítica é nos momentos de grande perigo, quando seus familiares estão

\footnotetext{
${ }^{217}$ Participo, como membro, desde 2006, da Comissão Nacional para Implementação e Acompanhamento dos Conselhos da Comunidade, órgão do Ministério da Justiça, e pude acompanhar vários casos de magistrados que desconheciam ou não eram simpáticos à atuação do Conselho da Comunidade. Em rápida pesquisa na rede de computadores encontrei o caso do juiz de Formosa, Goiás, que destituiu o conselho porque alguns de seus membros teriam sido empossados "sem conhecimento, ratificação ou aprovação do diretor do Foro, responsável estatutário pela escolha de novos membros". (disponível em: <www.tjgo.jus.br/bw/?p=2494>. Acesso em: 8 jul 2011).

${ }^{218}$ Alexandra Szafir narra com precisão um dia de visitas em uma penitenciária de São Paulo, situação vivida por ela própria quando teve que acompanhar a mulher de um preso, no que ela chamou de "nosso calvário" (2010, p.58).
} 
ameaçados por uma rebelião, uma invasão da polícia de choque ou uma transferência arbitrária de estabelecimento penal. Nestes momentos também é notória a força dessa gente, muitas vezes mobilizada na frente das penitenciárias, exigindo providências e aguardando notícias de seus entes queridos.

Não é por acaso que os agrupamentos sociais da periferia são chamados de comunidades, enquanto os grupos sociais das classes média e alta têm a denominação de associações, conselhos etc. Estes formam a chamada sociedade organizada, termo que vem evidentemente para diminuir o valor das comunidades. Comunidades se formam por interesses comuns, dores e sofrimentos comuns também, enquanto associações são mais um conjunto de interesses individuais egoístas. No mesmo passo, quanto à comunidade que se forma em torno dos problemas penitenciários, a força de atração é maior, visto que se pode personificar na instituição um obstáculo de todos. A aversão comum, como lembra Russell, “é uma das causas mais frequentes de uma simpatia instintiva" (1958, p. 20).

Para ocorrer realmente o diálogo, que se pretende viável, a crítica é imprescindível. Para que nos comuniquemos é necessário que haja crítica, pois, caso contrário, estaremos sempre repetindo um ao outro. A linguagem humana se diferencia da linguagem dos animais porque "torna possível um novo passo, uma nova invenção: a invenção da crítica" (POPPER, 2006, p. 19). Contudo, a crítica das comunidades é superficial, abafada pela força e pelo constrangimento que lhes é imposto, mantida na superficialidade até mesmo pela ausência do próprio diálogo. Quanto às entidades e associações previamente selecionadas pelo Estado, controladas pelo juiz e limitadas por suas próprias circunstâncias sociais de autocontrole, quando nelas nasce um pensamento crítico, este é logo tolhido pelo sistema, policial como um todo.

Sem que se possa discernir o certo do errado, o humano do desumano, o democrático do arbitrário, não se terá qualquer comunicação, ficando inviável o diálogo. E o sistema penitenciário é assim, um centro de violações e insensibilidades que é mantido com base na racionalidade ideal, falsificada e imposta dos sistemas jurídico e político.

Fala-se aqui da crítica necessária no interior do sistema, do diálogo, correndo-se o risco de se estar possibilitando a legitimação desse mesmo sistema. Contudo, não é o caso, pois o 
sistema punitivo não foi criado para a crítica ou para o diálogo. A própria Lei de Execução Penal, quando fala em participação da comunidade, ressalta suas duas grandes funções: a de colaborar com o judiciário e a assistência material, "em harmonia com a direção do estabelecimento" (Art. 81, III). A sua natureza de instrumento parceiro da repressão, que impede a reflexão partindo do seu interior, acabaria menos se renovando e mais se desestruturando com a crítica.

Poder-se-ia argumentar que as atividades dos conselhos da comunidade de emitir relatórios ao juízo da execução, visitar os estabelecimentos penais e entrevistar presos, contidas no art. 81 da LEP, levam à conduta crítica. Muitas vezes sim, e somos testemunhas de que muitos integrantes dos conselhos conseguem perceber a irracionalidade do sistema punitivo criado por sua própria sociedade, apesar de todas as limitações das quais já falamos. Mas o que dissemos sobre a ausência de mecanismos de coerção, sobre as restrições a que é sujeito o juiz da execução penal (3.1.2), constitui-se em problema redobrado para o conselho da comunidade, na forma como foi pensado pelo legislador, o que se agrava pela total falta de espaço para o debate e discussões, necessário para o desenvolvimento da crítica.

A crítica nunca estará em harmonia com a direção do estabelecimento. Não falo aqui de uma crítica revolucionária, longe disso, mas apenas de uma crítica que leve à reflexão, que seja informativa e argumentativa ao mesmo tempo, em prol da evolução da sociedade. Nem esta crítica é possível diante da fúria repressiva das instituições policiais do estado, entre elas incluídas as instituições penitenciárias, apesar de ter a crítica, a mínima crítica que seja, um papel primordial para o Estado Democrático de Direito.

Trata-se de exigências de uma sociedade democrática no sentido verdadeiro do termo. Em tal sociedade, a função da crítica é vital, no nível da cultura como em todos os outros. Porque talvez a melhor definição que se pode fornecer da democracia é aquela de um regime de autorreflexividade coletiva (CASTORIADIS, 2009, p. 93).

$\mathrm{O}$ que se tem dito sobre a dificuldade de crítica e, consequentemente, de diálogo, inerente à estrutura do Estado, assim como sobre os diversos obstáculos humanos relacionados principalmente à passividade do cidadão frente à burocratização do poder público, não afasta a importância da participação na execução penal de membros da sociedade de fora dos muros da prisão. Somente quem não acreditar mais na potencialidade do ser humano para a vida pode 
pensar que o ingresso dessas pessoas de fora não causaria qualquer efeito no mecanismo do sistema ou na estrutura destes seres humanos.

A denúncia que se faz da dificuldade de diálogo é justamente para que haja reflexão sobre tal circunstância. Mas não há como negar, uma pessoa que deixa a rotina pronta e acabada de sua vida social para ingressar em uma penitenciária, ficará certamente com alguma marca, resultante desse ingresso. A filantropia, a curiosidade ou o interesse pessoal, qualquer motivo que leve alguém a ultrapassar as barreiras mantidas pelo sistema ao seu redor, conquanto esses motivos carreguem grande dose de egoísmo, nunca serão suficientes para evitar que aquele que ultrapassou tais obstáculos e sentiu algo do sistema punitivo, continue indiferente.

Talvez a potencialidade de crítica esteja aí, na complexidade do ser humano. João Pissarra Esteves coloca acertadamente que "há forças que o sujeito não pode controlar inteiramente e das quais, muitas vezes, nem chega a tomar perfeita consciência, mas que nem por isso têm uma menor importância na sua constituição" (2003, p. 99), e podemos acrescentar que o indivíduo não poderá ser embargado para sempre pelas instituições ou pelas regras do sistema, e que a incoerência deste aumenta na exata proporção em que se desgastam as forças da passividade humana.

Dizendo de forma mais simples, a irracionalidade do sistema punitivo, a visão de alguém atrás de grades e em situação miserável, deprimente, alguém que deveria ser um cidadão, é algo que choca e faz mudar alguma coisa. Podemos acreditar que "a repugnância instintiva à crueldade e ao comportamento insensível certamente pode desempenhar um grande papel na prevenção contra as atrocidades" (SEN, 2011, p. 79). Frieza, revolta, tristeza, piedade, não importa, a visão do cárcere causa algo, e a consequência desse impacto poderá ficar no inconsciente ou se tornar reflexão, mas, de uma forma ou de outra, a potencialidade para a crítica existe.

E é partindo dessa perspectiva que tomamos a liberdade de fazer rapidamente uma análise particular do GDUCC (Grupo de Diálogo Universidade-Cárcere-Comunidade) ${ }^{219}$,

\footnotetext{
${ }^{219}$ O GDUCC iniciou suas atividades junto ao sistema penitenciário paulista no ano de 2006 e o autor deste trabalho teve a oportunidade de acompanhar as ações do grupo no ano de 2010, participando efetivamente das reuniões e debates no primeiro semestre do mesmo ano.
} 
grupo que teve entre seus idealizadores Alvino Augusto de Sá, professor da Universidade de São Paulo, Largo de São Francisco, e que parte dos "pressupostos da criminologia crítica elaborados pelo italiano Alessandro Baratta e pelo argentino Eugenio Raul Zaffaroni, visando contribuir para a integração entre segmentos da sociedade e para o fortalecimento psíquico do encarcerado" (BRAGA; BRETAN, 2008, p. 257).

Não tentaremos conceituar nem esgotar as atividades do GDUCC, até porque, como grupo de diálogo entre comunidade em meio livre e comunidade carcerária, a diversidade de fatores é tão grande que nenhum resumo seria satisfatório. $O$ diálogo, assim como a comunicação em geral, são conceitos que valem "para problematizar - e não para normalizar" (ESTEVES, 2003, p. 126). E por isso que a impressão sobre qualquer contato humano, o qual pressupõe comunicação, sempre será individual e não poderá integrar o arcabouço de conceitos e normas tão agradáveis ao sistema.

Vê-se, de antemão, que a proposta do grupo, ainda que partindo dos pressupostos de reintegração social, na designação de Baratta, optou por adotar apenas o termo diálogo e assim, ao invés de se limitar, ampliou suas possibilidades que, a meu ver, chegam até à possibilidade de sua própria inviabilidade. O diálogo, como algo que evolui e espaço de constante crítica, está invariavelmente aberto à sua própria incapacidade de prosseguir ou à conclusão de que o local penitenciário tem ruídos em demasia para possibilitar qualquer comunicação saudável.

Então, a princípio, nos limitaremos a expor o que percebemos de importante na atividade do GDUCC para a Universidade e para a sociedade como um todo, deixando de fazer, por enquanto, qualquer avaliação sobre o preso, até porque se não for viável livrar o homem que está em liberdade, de sua prisão conceitual sobre a punição, nenhum diálogo terá início.

Quebrando o histórico relacionamento hierárquico dentro da estrutura de ensino da qual faz parte a Universidade, reconhecendo que nela não ocorre somente transmissão de mensagens ou saber, mas que "ali acontecem muitas outras coisas e que se realiza toda uma modelagem dos indivíduos de acordo com as imagens reguladoras e as funções-chave da sociedade" (GUATTARI, 2004, p. 213), o GDUCC, como local aberto à crítica horizontal, 
sem imposição de valores, mas, muito mais do que isso, como espaço para apreensão de outros valores diversos dos que tradicionalmente são considerados científicos, tem um mérito acadêmico e social extraordinário.

Este grupo de alunos da Universidade de São Paulo não entra no cárcere para estudar seres humanos, mas para aprender entre seres humanos. $\mathrm{O}$ contato formado entre estudantes e presos tem continuidade, frequência certa, orientação crítica, enfim, todos os componentes de um grupo de diálogo. Valores, ideias, sentimentos e ressentimentos transitam livremente, permitindo a verdadeira transdisciplinaridade. É a lição de Alvino Augusto de Sá:

A Academia não deverá ter a pretensão (prepotente) de simplesmente fazer uma análise científica e neutra do crime, do cárcere e dos encarcerados, e nem a pretensão (igualmente prepotente) de buscar readequar eticamente os encarcerados. Mesmo porque tal tentativa de readequação ética, hoje em dia, estaria fadada ao fracasso. Pelo contrário. A Academia, em sua responsabilidade na questão penitenciária, deverá, isto sim, exercer uma liderança no sentido de retomada do diálogo entre comunidade e o cárcere, por meio da compreensão e, por que não dizer, aceitação da cultura, dos valores e da ética dos encarcerados, penetrando na subjetividade de suas histórias (2010, p. 185).

Permito-me fazer uma pequena ressalva a respeito da citação acima, a de que a readequação ética sempre esteve fadada ao fracasso e sempre fracassou. Todavia, a Academia, durante todos os anos da lamentável vida da pena de prisão, esteve realmente a maior parte do tempo afastada desse processo. A racionalidade científica, para manter a sua pureza e objetividade, não poderia conviver com o descaso que sempre foi a prisão. Por isso, somente uma postura científica mais humilde poderia ingressar no cárcere, pois assim estaria também permitindo que as mazelas deste penetrem o conhecimento dito científico, diminua sua certeza, aproximando-o da realidade.

Estivemos em grande parte deste trabalho observando decisões jurídicas que desconsideram a realidade do sistema penitenciário e tratam a ciência jurídica como algo abstrato, divorciado da real condição do encarcerado. Os integrantes da comunidade que entram na penitenciária por intermédio do GDUCC, futuros juízes, promotores e advogados, terão mais condições de superar essa enraizada visão científica que desconsidera o que é verdadeiramente uma prisão. E mais do que isso, tais profissionais terão a capacidade de superar o senso comum de que o preso é algum estranho, de que o criminoso é um anormal. Esta é uma das primeiras impressões do GDUCC: os rótulos se desfazem. 
Ao ter participado do GDUCC como aluno, embora seja juiz de direito há mais de dezoito anos, e há mais de dezoito anos visite estabelecimentos penais, tive uma séria sensação de que nunca havia conhecido nenhum preso até o primeiro dia de GDUCC. Não que não os tenha visto, pois já os vi muitos, vivos, mortos e mutilados, mas é que a relação de autoridade existente entre um juiz e um preso é dificílima de ser superada, por ambas as partes. Não adianta entrar na cela, ultrapassar as grades, aproximar-se de quem está preso, aquele que mantém o outro encarcerado estará fadado a uma comunicação bastante embaraçada.

Qualquer diálogo carece mais do que aproximação física, carece de liberdade de ideais, o que nem preso nem juiz possuem. O cárcere é antiprodução pura, "o cárcere não é diálogo, mas sua negação. O cárcere, por si mesmo, não é um caos, mas é um programa, um programa de degradação humana" (SÁ, 2011, p. 544), assim aquele que representa o cárcere e simboliza a figura do Estado repressor estará sempre na contramão do diálogo.

Certo que os membros da sociedade, o que se denomina comunidade visitando o cárcere, também carregam a bandeira da ordem social que tem o cárcere como algo legítimo. Mas é nesse sentido o grande valor que atribuímos à proposta do GDUCC, pois trazer a comunidade para o cárcere dentro de uma proposta livre para a crítica é essencial, sobretudo porque, no caso, abre-se espaço para a autocrítica.

Será natural o se questionar, pois o "o Grande Diálogo é baseado na ideia de que interesses e experiências compartilhados são mais importantes do que conceitos compartilhados" (FROMM, [1977], p. 158), e a aparente divergência de valores é secundária quando as experiências de cada um se encontram e dialogam. Ainda que vivendo realidades diferentes, o membro da comunidade e o encarcerado, quando têm a oportunidade de se conhecerem como pessoas, identificam experiências comuns de seres humanos e essa cumplicidade tem um potencial maior de fazer aquele que está do lado de fora sentir mais próxima a violência do cárcere.

Muitos dos obstáculos observados para a participação efetiva da comunidade na execução penal são resultados da falta de crença em que algo pode ser mudado, situação repetida em quiçá todas as áreas da vida, cujo resultado é também a passividade quase geral com relação às demais violações percebidas em meio livre. Se o respeito mútuo e a devolução 
de força à comunidade "têm que ser estimuladas sobre fundamentos convincentes" (FERNÁNDEZ-ARMESTO, 2000, p. 18), somente um contato no qual se estimule a reflexão, de membros da comunidade com o cárcere, pode proporcionar o engajamento proposto pela, que se espera, mas não tem ocorrido satisfatoriamente.

\subsubsection{O preso}

A comunicação de massas não é formadora só de opiniões ou de valores, sendo extremamente relevante ressaltar a "fundamental importância que têm os meios de comunicação a influenciar na conformação das atitudes humanas e em suas formas de conduta" (SHECAIRA, 2001, p. 256), modificando, podemos dizer, a estrutura do sistema social como um todo. Tal constatação torna patente, desde o início, a dificuldade de diálogo no contexto comunicacional de uma sociedade passiva frente ao seu principal instrumento de transmissão de saberes.

Forma-se uma estrutura comunicacional em que, por suas características, o emissor não recebe qualquer feedback imediato do receptor. Em uma sociedade assim, tão automatizada e acostumada a receber mensagens sem poder a elas se opor, é natural que o poder historicamente exercido nesta sociedade, principalmente sobre os seus entes punidos, raramente levados em consideração como pessoas, seja um poder que se comunica ignorando o receptor. Ainda assim, tentaremos falar algo do que pode ser esse diálogo com o preso, e do que pode ser a visão desse preso, da mensagem que lhe tem sido passada ou do obstáculo existente na incompreensão de tal mensagem.

Acima de tudo, para se verificar a possibilidade de diálogo em qualquer que seja a situação, é imprescindível nos coloquemos no lugar do outro, receptor, mas também emissor de mensagens. Contudo, nenhum expert, nenhum jurista, psicólogo ou filósofo é capaz de aquilatar o sofrimento, o consequente limite de raciocínio, a confusão de perspectivas, de um ser humano encarcerado. Nem mesmo um preso pode avaliar as condições de outro preso, porque a dor não é mensurável e o aprisionamento é sentido de forma diferente por cada um. Por isso, o que será dito aqui mais uma vez foge da pretensão científico-moderna de certeza. 
Ao avaliar a prática judicial na execução da pena e as diversas jurisprudências que trouxemos, uma questão esteve sempre implícita e não raras vezes explícita: a mentira. Não há dúvida, a mentira é o cessar do diálogo, é transportar a comunicação para um local de insegurança, de fantasia. Nem a resposta à mentira, por mais sincera que seja, alcança a realidade, porque o diálogo cessou e a comunicação não está mais acontecendo no mundo das coisas concretas.

Quando se encarcera de forma ilegal, violam-se direitos expressos em leis, na Constituição e em tratados internacionais, mas se faz de conta que a pena privativa de liberdade é uma punição legítima e, pior, voltada para a ressocialização daquele que está privado da liberdade; aí não se pode esperar diálogo. Tanto o direito como ciência, quanto o direito institucionalizado e incorporado nas diversas autoridades que o representam, ao camuflarem ou dissimularem a realidade de desrespeito que é o sistema penitenciário, estão mentido.

Conquanto a mentira tenha se tornado algo comum nos dias de hoje, que passa como supérfluo nas relações pessoais do dia a dia, para aquele que está encarcerado é diferente. São dias, meses, anos, em que qualquer forma de engodo será objeto de maior padecimento. Concepcíon Arenal, há quase duzentos anos atrás, já dava um conselho nesse sentido para aqueles que visitam os presos:

"A dificuldade de enganar a um homem encarcerado é grande, porque não só é receoso e desconfiado, mas também no triste ócio de seu pensamento e de seu coração, e na monotonia de sua vida, o visitador é uma ocupação e uma novidade que lhe impressiona muito, e recorda, pode dizer-se que rumina, tudo que viu e ouviu na visita [...] Se descobriu que o visitador fingiu uma vez? Então já terá por coisa segura que não é sincero nunca"220 $(2000$, p. 22-23).

A advertência da pensadora espanhola não serve só para o visitador. Serve para o legislador e para o julgador também, porque por mais que não se trate o preso como sujeito de direitos, mas sim como objeto, tal fato não mudará a realidade de que ele, o preso, é um ser

\footnotetext{
${ }^{220}$ Tradução livre de: "La dificuldad de engañar á un hombre encarcelado es grande, porque no sólo es suspicaz y desconfiado, sino que en el triste ócio de su inteligencia y de su corazón, y en la monotonía de su vida, el visitador es una ocupación y una novidad que le impresiona mucho, y recuerda, puede decirse que rumia, todo lo que ha visto y oído en la visita [...] ¿ Se descubrió que el visitador fingió una vez ? Pues ya tenderá por cosa segura que no es sincero nunca" (ARENAL, 2000, p. 22-23). (Grifo no original).
} 
humano e percebe esse tratamento, sente que é figura passiva em uma relação que deveria ser de direitos, sente e rumina esse descaso.

Já para os que verdadeiramente se fazem presentes no estabelecimento penal, a mensagem é de grande relevância, uma vez que o discurso sem a prática se tornará mentira e a omissão pode se constituir em violência. A palavra oriunda da maior das boas intenções, dentro do sistema penitenciário, é mentira se quem a disser estiver escamoteando a realidade, se quem a pronunciar, por exemplo, tiver acabado de passar por uma cela escura, por uma tortura, e fizer que não as viu. Essa mentira se ruminará também e inviabilizará o diálogo.

A mensagem, em qualquer comunicação, não pode ser separada de tudo aquilo que ela representa. O preso, receptor, estará sempre pronto para sentir o que não for e o que for verdadeiro nas relações entre grades. "A pessoa, em primeiro lugar, infere do comportamento da outra a ideia ou o sentimento que a outra está tentando transmitir. Ele então responde, não ao comportamento em si, mas à ideia ou ao sentimento inferido" (RILEY; RILEY, 1978, p. 150). Assim, qualquer pessoa autorizada pela administração a entrar em um estabelecimento penal, transmitirá muito mais do que pensa e trará consigo toda a carga de irracionalidade do poder.

Falando de mentira, ocorre-nos outro assunto. Estivemos abordando a questão do diálogo, mas algo fundamental, ao menos na perspectiva do preso, não foi suficientemente abordado, que é o conteúdo desse diálogo. O que o Estado, e também as instituições e a sociedade querem dizer ao preso talvez não seja o que ele quer ouvir. E é bem certo que para se travar um diálogo é necessário ser o tema interessante para ambas as partes. Pode-se pretender não cometa o preso mais crimes, que ele entenda as regras da sociedade ou seja o menos dessocializado possível naqueles anos de cárcere, mas esses interesses não serão o do preso e nenhuma mensagem chegará a ele se a comunicação partir do interesse unilateral de quem emite a mensagem.

E qual o interesse do preso? Neste ponto, não temos dúvidas em afirmar: é a liberdade. A reclusão não é uma condição natural do ser humano e a liberdade privada estará presente em todos os temas de interesse do preso. Será o tema principal e o tema secundário em qualquer assunto que com ele se trate. Sem a inclusão da liberdade daquele cidadão no tema de 
qualquer questão a ser tratada, essa questão perderá valor, não terá relevância, e será esquecida na primeira oportunidade.

Como o doente sedento pensa, sonha e delira com água, a ideia fixa do preso é a liberdade: surgirá em qualquer situação de vida, e até como supremo consolo na morte. Ainda que esteja desacreditado e contados os dias de sua existência, ainda que só tivesse horas para viver, quer morrer fora da prisão, quer ter este consolo (...) Muitos não sabem a idade que têm; outros duvidam quanto possuem de pecúlio; quanto ao tempo que falta para cumprir, nenhum possui qualquer dúvida; a liberdade é a ideia fixa de $\operatorname{todos}^{221}$ (ARENAL, 1895-b, p. 191-192).

Por certo há casos excepcionais em que o preso pode não aparentar estar tão sedento ou desesperado, como faz sugerir a citação da pensadora espanhola, ou o exemplo de Malcom X, apresentado anteriormente (2.4), que, quando preso, viu na leitura uma liberdade nunca antes encontrada. No entanto, nenhum preso, nem mesmo o líder negro norte-americano, por mais atividades prazerosas gozadas na cadeia, e ainda que todos os seus direitos estejam respeitados, ou desrespeitados, deixará de considerar como o seu maior desejo e interesse, a liberdade corporal, ou seja, estar distante das grades.

Nas rebeliões, tão comuns - deve-se salientar - em todos os sistemas penitenciários, quando a reivindicação é que se cesse alguma tortura, conceda-se um maior tempo de banho de sol, diminuam-se as extorsões, ou acabem as revistas vexatórias aos familiares, enfim, apresentado o argumento que for, em qualquer situação, a liberdade estará na pauta de requerimentos, seja na forma de reclamação pelo atraso na avaliação de direitos inerentes à execução penal, seja como protesto contra o total abandono no que se refere à ausência de informações sobre o processo. Nessas rebeliões, mais parece ser o fato principal apenas a gota d'água. Aquele desrespeito contra algum direito humano só veio para tornar insuportável a espera da liberdade.

Somos testemunhas de que a ânsia pela liberdade chega mesmo a causar desunião em qualquer solidariedade surgida durante o movimento entre os presos. Havendo um líder (e rebeliões são sempre melhor administradas e administráveis pela própria força policial,

\footnotetext{
${ }^{221}$ Tradução livre de: "Como el enfermo sediento piensa y sueña y delira con agua, la idea fija del recluso es la liberdad: se le aparece bajo todas las formas seductoras de la vida, y hasta como supremo consuelo en la muerte. Aunque desahuciado tenga contados los dias de su existência, aunque sólo haya de vivir horas, quiere morir fuera de la prisión, quiere tener este consolo (...) Muchos no saben la edad que tienen; otros olvidan á cuánto asciende su fondo de reserva; el tiempo que les falta para cumplir, no lo olvida ninguno; la libertad es la idea fija de todos" (ARENAL, 1895-b, p. 191-192). (Grifo no original).
} 
quando há um líder), basta negociar com este uma melhor avaliação do seu direito, acenar para a proximidade de seu livramento condicional ou de sua progressão, que visivelmente a rebelião ameniza e caminha para o fim. A falta de esperança, a falta de informações sobre a liberdade $^{222}$, é, para o preso, a maior tortura.

E quando um preso, após cumprir sua pena, pede para continuar na penitenciária? Situação que já presenciamos e que, embora não seja comum, é sempre relacionada a penas extremamente longas. Desnecessário relembrar as consequências de uma instituição total que torna a pessoa "incapaz de enfrentar alguns aspectos de sua vida diária" (GOFFMAN, 2001, p. 23), porque essa morte da autonomia do ser humano soma-se à realidade inóspita do lado de fora para fazê-lo aterrorizado com a vida em meio livre. Contudo, mesmo nesses casos, o preso quer a sua liberdade declarada, ele quer o direito de sair do estabelecimento penal, por mais que more nele para o resto da vida.

Há um aparente impasse para o diálogo. De um lado o Estado e a sociedade pretendem evitar o crime, do outro o preso precisando, sonhando, implorando a liberdade. O Estado não acredita na sua instituição prisão, apenas diz acreditar por intermédio de seus discursos legais e dogmáticos, e por isso acaba vendo o encarceramento como forma de excluir o preso, ao menos temporariamente, das situações de crime. De seu turno, o preso finge acreditar na prisão, não discute o descumprimento por parte do Estado de grande parcela de seus direitos, porque sabe que a hipocrisia do sistema é o caminho mais próximo do reconhecimento dos benefícios que o aproximarão da liberdade.

O impasse é aparente porque o conflito aqui não é de interesses, mas de meios. A exclusão pura e simples é, com efeito, incompatível com a liberdade almejada. Mas a exclusão é só o meio que a política estatal tem encontrado para justificar que (não) está fazendo algo. A exclusão não é nem mais forma de controle das classes perigosas. Hoje em dia, para ser preso, não basta ser pobre, tem que ser miserável e azarado. A criminalidade continua, seja nos altos, seja nos baixos escalões, e a exclusão de pequena parcela da sociedade que

\footnotetext{
${ }^{222}$ Lola Aniyar de Castro faz uma lembrança pertinente, a de que quando a rebelião é em cadeia pública, onde estão recolhidos só detentos aguardando julgamento, a chegada de uma sentença, mesmo condenatória, é tida como forma de "serenar" o preso. Nas palavras da autora, sobe "a temperatura da caldeira por conta da insegurança e da ansiedade dos presos à espera da sentença" (2010, p. 90).
} 
desafortunadamente caiu nas malhas desgastadas do sistema penal serve tão somente, se é que ainda serve, como justificativa de sobrevivência do próprio sistema.

Devem-se alterar os meios se realmente se pretende chegar a algum fim, ou, dentro da perspectiva que estamos traçando, se realmente se quer alcançar a possibilidade de diálogo entre o direito e o cidadão ou entre o Estado e o preso. E o único meio, dentro das diversas circunstâncias - a maioria dessas circunstâncias nem tratadas neste trabalho - o único meio para se alcançar qualquer diálogo é o respeito irrenunciável, inflexível, absoluto, à lei.

A sociedade, que se pretende constituída sob o traço do Estado Democrático de Direito, não pode agir, não pode sequer pensar a sua própria existência, dentro do desrespeito às normas que ela própria aceita como impositivas. Este é o caminho inicial do diálogo. Se ele levará ou não à diminuição do crime, não sabemos e é bem provável que não leve se, no contexto social como um todo, o Estado continuar descumprindo mais uma vez a Constituição Federal. Aí, pois, a razão de Baratta e Sá ressaltarem a reintegração social, que tem o diálogo como conteúdo, apesar da prisão. O diálogo no meio social passa igualmente pelo respeito às regras constitucionais básicas. Como diz Nilo Batista, "supor que boas penitenciárias darão segurança pessoal a todos é o mesmo que equacionar em bons hospitais a saúde pública esquecendo a alimentação, a higiene, o sistema de água e esgoto etc.” (1990, p. 173).

Voltando à situação do preso, não há como esperar deste o início do diálogo. A pessoa sem liberdade se submeterá ao jogo necessário para recobrar o que lhe foi tirado, e o jogo do sistema, atualmente ilegal e irracional, fará com que o preso tenha que se adaptar a ele. Além do fato de que não se conquista sinceridade mentindo, nem desrespeitando as regras do jogo estabelecidas previamente, deve-se considerar que são séculos de um sistema penitenciário deplorável, de práticas corroídas, onde a dissimulação é a atitude de defesa e de ganhos com maiores resultados.

Além da condição de ser humano do preso que, apesar de privado de inúmeros direitos e vivendo em condições não raramente desumanas, não quer aparecer como doente ou como coitado em uma relação que, para ele, é normal, fato que lhe coloca na necessidade de fingir a 
própria dignidade ${ }^{223}$, além disso, o autoritarismo e a falta de espaços para que o preso exerça a sua vontade pessoal, a passividade exigida pelo sistema, vão deixando a pessoa do recluso cada vez mais artificial e arredia a qualquer iniciativa de diálogo.

É certo que "o preso tem preconceito com outro preso, o preso acha o outro um mau sujeito, ele se incorpora ao estado punitivo",224, porque "os condenados estão fazendo o mesmo teatro que fazemos" (MORAES, 1998, p. 251), e por isso muito do que foi dito anteriormente sobre a sociedade em geral serve também para simbolizar a imagem que o próprio preso tem do sistema punitivo. Mas, dentro do cárcere, o preso não se submete a esse teatro somente porque incorporou o estado punitivo, mas sim, e principalmente, porque precisa. A liberdade só será alcançada na encenação necessária ao sistema. Por isso que o discurso do preso está igualmente embaraçado pela prática judicial e administrativa, porque ele precisa reproduzir a fala e o argumento, mesmo que equívocos, daqueles que estão com a chave da cadeia.

Sobre fingir a dignidade, se é possível afirmar ser a humilhação um sentimento que se tende a esconder, pode-se igualmente concluir, quanto à conduta de ocultar emoções, que tal procedimento sempre levará consigo a espontaneidade importante para a comunicação. O preso precisa ser aceito e estar apresentável para o sistema que não o quer destruído, precisa fingir comportamento, fala, dor, precisa fingir praticamente tudo. Talvez finja até o preconceito que sente sobre o outro preso, do qual acabamos de falar.

Mas, obviamente, neste campo, como em todos os outros em o homem está incluído, não há como exemplificar uma atitude humana sequer que sirva como padrão. Por isso ficamos mais uma vez com Concepción Arenal quando lembra, se "todo homem é diferente de outro homem, um preso é ainda mais de outro preso" 225 (p. 34), concluindo que "quando um

\footnotetext{
${ }^{223}$ Para Concepción Arenal, "na hipocrisia, como em tudo, há graus, e ademais diferenças: ainda que não tenha a pretensão de ocultar a fisionomia moral do delinquente, este não tem sempre o propósito deliberado de enganar; muitas vezes cede ao natural desejo de não aparecer com todas suas debilidades, com todas as suas faltas, com todos os seus crimes, de fazer-se menos odioso negando os fatos ou os motivos que lhe impulsionaram" (2000, p. 35-36). No original: "En la hipocresía, como en todo, hay grados, y además diferencias: aunque no tenga de común la pretensión de ocultar la fisionomia moral del delincuente, éste no forma siempre el propósito deliberado de engañar; muchas veces cede al natural deseo de no aparecer con todas sus debilidades, con todas sus faltas, con todos sus crímenes, de hacerce menos odioso negando los hechos ó los móviles que le impulsionaron".

${ }^{224}$ Nesta citação, o médico Talvane de Moraes faz referência a uma pesquisa realizada pelo juiz da execução penal no Distrito Federal, George Lopes Leite. Em itálico no original.

${ }^{225}$ No original: "Todo hombre difiere de outro hombre, el preso aún más de otro preso" (ARENAL, 2000, p. 34).
} 
visitante observa algo comum à imensa maioria dos presos, algo que não parece relacionar-se com seu temperamento nem com seu delito, este algo é o cativeiro",226 (2000, p. 52).

Como o motivo da grande diferença entre as pessoas não reside na racionalidade, que deveria regular a vida de todos em sociedade, mas sim nas emoções, instintos e desejos de cada um, uma conjuntura desnatural como a do cárcere só pode exaltar os aspectos psicológicos que mais nos tornam diferentes, razão pela qual não continuaremos nos alongando sobre a situação da pessoa no cárcere, bastando, por enquanto, o já dito sobre mentira e liberdade.

\subsection{Consciência política}

Dissemos que sem consciência não pode haver diálogo (4.2.1) e o mesmo vale mais do que nunca para o preso, pois diante de toda uma série de obstáculos restringidores não só da liberdade de locomoção, a ausência de consciência do que está acontecendo ao seu redor como pessoa e como integrante da sociedade só agrava a punição. Toda a hipocrisia, a dissimulação e a falsidade que há no meio penitenciário e na prática judicial, não passam despercebidas pelo preso. Deixá-lo pensar em tais práticas como naturais das regras sociais que ele infringiu é desistir da característica dialogal que deveria ter o Direito.

Alvino Augusto de Sá faz um interessante paralelo entre os pensamentos de Alessandro Baratta e Cezar Roberto Bitencourt, sobre a conveniência ou não de o preso possuir consciência política. Assim resume a proposta de Baratta, o professor da Universidade de São Paulo:

[Baratta] traz uma proposta um tanto quanto mais arrojada sobre 'reeducação' de encarcerados. A saber, a verdadeira reeducação de consciência política sobre as contradições da sociedade, sobre as relações de domínio e de poder, sobre as condições das classes subalternas e os motivos dessas condições. Com isto, o encarcerado poderia vir a substituir suas respostas irracionais, que se dão num âmbito puramente individual e não produzem as transformações sociais almejadas, por respostas racionais, não individuais, inseridos num contexto mais amplo e coletivo de luta (SÁ, 2010, p. 58-59).

Depois, Sá explica que as objeções de Bitencourt à proposição de Baratta têm dois aspectos, um prático e outro teórico:

\footnotetext{
226 “cuando el visitador observa algo común á la inmensa mayoría de los reclusos, algo que no parece realcionarse con su temperamento ni con su delito, este algo es el cativerio" (Idem, p. 52).
} 
Sob o aspecto teórico, diz Bitencourt que, embora as questões políticas e econômicas estejam sempre presentes, 'não se pode afirmar que toda delinquência das classes inferiores seja uma respostas às condições de vida que o sistema capitalista impõe' [...] Sob o aspecto prático, diz Bitencourt que o desenvolvimento de uma consciência política no deliquente é uma questão muito complicada, pois corre-se o risco de proceder a uma manipulação ideológica dos condenados, manipulação de ideias e valores, o que não deixa de ser uma manipulação de poder, à qual se contrapõe, no plano consciente e teórico, todo posicionamento crítico da Criminologia (Idem, Ibidem, p. 59).

Não acreditamos possa ter a sociedade qualquer alteração de sua base sócio-econômica por intermédio do cárcere. Da mesma forma como dissemos não conseguir o encarceramento alcançar muitos avanços no seio do próprio cárcere (4.1), por motivos muito mais evidentes não podemos considerar possível a mudança da sociedade como um todo por iniciativa dos cidadãos saídos de suas prisões. Lembremos que a Bastilha foi demolida por fora. Mas em razão dessa impossibilidade prática, seria viável, humano e digno, vedar ao preso a consciência do que se passa nas relações sociais que o levaram à situação de punido, e punido de forma ilegal?

Pretender que o preso tenha consciência política é falar a verdade e não doutriná-lo para este ou aquele valor social. Consciência política é consciência da sua situação de igual, mas desigual ao mesmo tempo; da sua situação de sujeitado a uma lei cumprida apenas parcialmente por quem o sujeita. Consciência política não é algo negativo que desestruturaria a sociedade ou os poderes constituídos, mas é a consciência capaz de dar a legitimidade que está faltando a esses poderes.

Por certo há outra dificuldade prática para a conscientização do preso acerca do seu lugar na sociedade, pelo menos no Brasil, onde $80.95 \%{ }^{227}$ da população carcerária não tem o ensino médio completo ou, como diz Gerivaldo Neiva, “'desenham o nome’ e não conseguem ler duas linhas" $(2011)^{228}$, sendo que apenas 8,97 \% dos presos estão estudando e "78,99\% desses estudantes estão ainda na fase (até o ensino fundamental) de aprender assinar o nome e

227 Dados do Sistema Integrado de Informações Penitenciárias - Infopen, que podem ser obtidos em: $<$ portal.mj.gov.br/>.

${ }^{228} \mathrm{O}$ autor, juiz de direito, usa os dados do Infopen em texto publicado no seu blog: "Como se começa de novo sem nunca ter começado antes?"; referência ao projeto Começar de Novo do CNJ, sendo importante transcrever a conclusão do texto: “... penso que precisamos todos - desde o ensino jurídico ao CNJ e passando por todos chamados "operadores do direito" - repensar o sistema punitivo e carcerário brasileiro, embasando qualquer teoria ou programa na realidade das periferias das grandes cidades do país, na miséria, na pobreza, em séculos de excluão... Enfim, mais perto da vida real do que dos gabinetes". (Itálico no original). Acesso em: 07 ago 2011. Disponível em $<$ www.gerivaldoneiva.com $>$. 
ler duas linhas" (Idem). Lembremos que "a democracia, em sua forma moderna, seria inteiramente impossível numa nação em que muitos homens não soubessem ler" (RUSSEL, 1958, p. 46).

Todas as outras circunstâncias desumanas da prisão contribuem para inviabilizar não só a consciência política, mas qualquer estado psíquico saudável. O psicanalista norteamericano Salman Akhtar fala principalmente de refugiados atingidos por situações desumanas causadas pela guerra, mas suas considerações não coincidentemente se encaixam perfeitamente nas condições do cárcere:

"Não se pode esperar que um indivíduo ou grupo ameaçado por violência, toques de
recolher, privação de comida, falta de suprimentos médicos, pobreza, superlotação e
imundície pense racionalmente sobre assuntos de diferença política ou religiosa.
Portanto, é preciso corrigir, ou ao menos atenuar essas situações [...] Com certeza,
minimizar o sentimento de humilhação do grupo em mãos de outros, promover
fóruns para verbalização de queixas do grupo e garantir liberdades política e religiosa
de seus membros são de importância fundamental para o atendimento dessas
necessidades" (2008, p. 135).

Na obra em que colhemos o texto acima, a qual tem o título sugestivo de Violência ou Diálogo?, há diversos artigos sobre questões relacionadas aos traumas de guerra como a “dificuldade de dar sentido à nossa experiência" (p. 203), o abandono, o desamparo, o prejuízo aos sentimentos básicos de confiança e domínio, afetando a "onipotência infantil e autoidealização, que são aspectos subjacentes necessários para garantir o sentimento subjacente de segurança" (p.203), com conclusões como a de que "em estados de perturbação, a pessoa pode ficar incapaz de simbolizar e, portanto, de entender emoções e sensações difíceis" (VARVIN, 2008 , p. 205). Curioso notar que todos esses sintomas são semelhantes a muitos da pessoa presa, com a grande diferença de que foram estudados em situações tidas como póstraumáticas, enquanto que para o preso a prisão é o próprio trauma presente.

Não obstante tais obstáculos, deve-se sempre permitir e buscar todas as condições possíveis para que o preso possa se localizar como membro da sociedade. Aliás, vedar a possibilidade de se alcançar alguma consciência política já é tratá-lo como diferente. Por que só o preso não pode ter essa consciência? E é de se ressaltar: não só o preso que precisado dessa conscientização, mas todos os integrantes da sociedade, inclusive os operadores do direito que vimos neste trabalho usando o termo ressocialização como argumento científico 
para encarcerar, sem nenhum dado empírico, mas, muito pelo contrário, diante da realidade e da notória ineficácia reeducadora da prisão.

Consciência política é consciência do mundo que nos envolve, das relações que nos influenciam, sejam estas de poder ou de micropoderes, para usar a linguagem foucaultiana. Consciência política, no direito, é percebê-lo mais do que pura técnica. A ideia, por sinal, de o poder judiciário atuar mediante um tecnicismo imparcial, impede vê-lo como verdadeiro poder ou "desdobramento do único poder que é o político" (SHECAIRA, 2001, p. 355). E a dominação técnica é "meio de tolher a sua consciência. Ela impede a formação de indivíduos autônomos, independentes, capazes de julgar e de decidir conscientemente. Mas estes constituem, contudo, a condição prévia de uma sociedade democrática (ADORNO, 1978, p. 295).

As jurisprudências tratadas, que desconsideram a realidade desconsiderando o cidadão, resultam da indiferença. O preso não é igual, é diferente e indiferente. E enquanto essa diferença e o ódio derivado dela parecem persistir no inconsciente de todos, o mal em que tem se tornado a prática penal cada vez mais perde a capacidade de se esconder no tecnicismo jurídico. A prática jurisprudencial vem se denunciando. O que está no inconsciente dos juízes ou, em outras palavras, na sua alienação, é a posição autoritária que ocupam no sistema dado, e não o mal efetivamente causado ao cidadão que se coloca para ser julgado.

E tal situação segue sem oposição, diante da passividade que é o oposto do que se poderia conceber como prática política. O que é a nossa dificuldade de vivenciar uma democracia verdadeira e participativa, senão a nossa passividade, que se traduz em silêncio e negação. A nossa dificuldade de diálogo, de crítica e de se opor ao estado atual das coisas está estreitamente relacionada à nossa dificuldade de construir um convívio democrático. Democracia é diálogo ${ }^{229}$, por isso o silêncio, que é o oposto da comunicação e do diálogo, é também a característica do cidadão já descrente na participação democrática sobre decisões que influenciarão na sua própria vida.

\footnotetext{
${ }^{229}$ Usando mais uma vez a força das palavras de Castoriadis: "Esta exigência de diálogo, de falar e deixar falar, de escutar e de fazer escutar, é também o que define, em um outro nível, mas sem deslizamento de sentido, o meio termo vital da democracia" (2009, p. 76).
} 
E se pretendemos viver uma democracia de massas, ninguém pode ser excluído do debate político, ninguém pode ficar sem voz, conhecimento ou esclarecimento a respeito das decisões que poderão marcar o rumo de nossa sociedade. Não há motivos para se excluir o preso de um projeto democrático.

A alegação acima referida, de não se poder "afirmar que toda delinquencia das classes inferiores seja uma resposta às condições de vida que o sistema capitalista impõe" (Bitencourt apud Sá, 2010, p. 59) é extremamente relativa, não só porque o sistema capitalista não abrange apenas as relações econômicas, mas ainda influencia conceitos, valores e comportamentos nas esferas pública e privada, como também porque a grande maioria dos crimes está realmente ligada à pobreza, à miséria e à humilhação das classes que deveriam ter direitos e condições iguais e nunca deveriam receber o tratamento de inferiores.

Voltamos a nos socorrer das observações de Gerivaldo Neiva sobre o senso penitenciário: "verifico que 50,42\% dos presos desse país cometeram crime contra o patrimônio (furtaram ou roubaram) e que $23,47 \%$ praticaram crime de tráfico, ou seja, $73 \%$ dos presos desse país estão presos porque furtaram, roubaram ou traficaram" (Idem). Somando-se a tais dados a constatação da experiência de que muitos homicídios, lesões corporais e até mesmo crimes de violência sexual, são cometidos com motivações ou em circunstâncias originadas na desigualdade econômica e social entre (ou dos) envolvidos, o índice de delinquência resultante das condições impostas pelo sistema capitalista cresce bastante.

Partindo de uma visão política mais ampla e buscando auxílio no poder de síntese de Nilo Batista, podemos dizer que "a pena é o pior modelo de decisão de conflitos. Quando você criminaliza um conflito, faz uma opção política. Não existe um crime natural. Todo crime é político" $(2003 \text {, p. 29) })^{230}$. Consciência política é reconhecer algo que parece tão trivial, que o crime e a pena são resultados de um processo político.

\footnotetext{
${ }^{230}$ Continua Nilo Batista: "Nos anos 70, eu me lembro que o Augusto Thompson, que é uma grande figura, deu uma resposta maravilhosa numa conferência, a um aluno que perguntou 'Professor, qual é a diferença entre criminoso comum e criminoso político?' E o Thompson falou: 'A diferença é que o comum também é político, só que ele não sabe"” (2003, p. 29).
} 
Talvez as restrições de Bitencourt a uma conscientização (ou reeducação) política do preso estejam ligadas ao passado da guerra fria, ao medo de um mundo comunista ou seja lá o que mais uma guerra ideológica pode impor. Mas hoje, com a morte do fantasma da esquerda, o medo da liberdade de pensamento, de crítica, de posições contrárias ou estranhas, não deve prosperar. Não pode haver medo de uma abertura democrática extremada, não há risco de se proceder a uma manipulação ideológica dos condenados se o que se ensinar (e praticar) for a atividade democrática. A manipulação ideológica está justamente na omissão, no faz de conta de que tudo transcorre de forma correta e justa, vedando o debate democrático sobre diversas questões.

Democracia não se impõe, pratica-se. Não se ensina, aprende-se praticando. E, ademais, é impossível se pretender a estagnação de ideias. Faz parte da democracia, assim como de qualquer diálogo, a infinita controvérsia. A ausência de divergência, o consenso em uma verdadeira democracia, deve ser sempre passageiro. Nas palavras de Chantal Mouffe, “democracia é caracterizada pela «dissolução dos sinalizadores de certeza». Numa sociedade democrática moderna já não pode existir uma unidade substancial e a divisão tem que ser encarada como constitutiva" (1996, p. 74).

Em uma sociedade democrática só deve ser excluído do debate quem não participa dela, quem está excluído da sociedade, por isso que excluir o preso do debate político é excluílo (mais uma vez) da sociedade. E nesse contexto de exclusão não há que se esperar nenhum comportamento responsável no sentido de respeito às normas. O Direito que se pretende diálogo e, portanto, compreendido, precisa ser realizado plenamente e, se não o for, é preciso que sejam explicados os motivos e as dificuldades de sua implementação, com espaços para crítica e sugestões que o façam verdadeiro instrumento de um Estado Democrático de Direito.

A concepção do preso como sujeito de direitos que temos defendido não se concretizará sem se reconhecer como diretamente relacionada à ideia de sujeito de direitos, a de sujeito político - a ideia da pessoa presa como cidadã - pois de nada adianta a afirmação de que essa pessoa é sujeito de direitos, sem se dar condições a este mesmo sujeito, de reivindicar o seu próprio direito. Direito não é favor, mas sim poder, e o sujeito de direitos precisa ser capaz de efetivar o seu poder, ou seja, de fazer valer os seus direitos, o que só será possível com uma cognição mínima de sua posição social. 
Tal perspectiva tem sua maior dificuldade justamente no fato de que o reconhecimento de um poder equivale à diminuição de outro:

Os que detêm o poder conhecem muito bem a diferença entre direito e permissão. [...] O direito, no sentido estrito da palavra, dá acesso ao exercício de um poder à custa de outro poder. A permissão não diminui o poder de quem a concede, não aumenta o poder de quem a recebe (Jean-Claude Milner apud Žižek, 2011, p. 58).

Talvez nesta citação esteja o motivo pelo qual tanto se insiste na palavra benefício em substituição à palavra direito. Os direitos inerentes à execução penal viram permissão, como um obstáculo a mais para a sua concessão. Ao mesmo tempo, a situação precária do sistema prisional deve ser mantida, reforçando o caráter de benefício de cada direito efetivado a duras custas, pois "os opressores, falsamente generosos, têm necessidade, para que sua 'generosidade' continue tendo oportunidade de realizar-se, da permanência da injustiça" (FREIRE, 2011, p. 42).

Nem a substituição do ideal de ressocialização pelo princípio da dignidade da pessoa humana que propomos teria sucesso sem a consideração do preso como sujeito de direitos, capaz de exigir o que lhe é devido. Neste caso, a dignidade de cima para baixo torna-se piedade e não difere em nada de tudo o que se tem feito em nome do pensamento ressocializador. A dignidade permitida ao cidadão preso fica, como todos os projetos ressocializadores, subordinada ao interesse da política governamental do momento.

Assim, os termos política econômica, política educacional, política ecológica, política penal e criminal, entre outros, são termos que servem para especificar determinado caminho traçado pelo Estado para alcançar determinado fim, mas são termos que igualmente escondem e embaraçam o caráter geral da política. Todas essas políticas não serão políticas, no sentido de resultado de um processo político, se são impostas. Serão atos arbitrários que se aproveitam da despolitização das pessoas atingidas por eles.

O espaço público despolitizado é o espaço de desenvolvimento dessas políticas especializadas por excelência. Tão especializadas que não se comunicam nem entre si e permitem a manutenção de princípios e conteúdos desconexos, como tem sido a própria ressocialização, encampada pela tal política penal ou criminal para formar um discurso dissociado da realidade. 
E nem se diga que retirando todos os obstáculos referidos acima, acerca da desumanização do cárcere, do histórico abandono dos miseráveis que lá estão recolhidos, do analfabetismo e do descaso, não se diga que afastando tais obstáculos ainda assim o ser humano preso, por ter delinquido, apresenta fraquezas que não o tornam apto para a vida democrática.

Tal não pode ser dito pela simples razão de que nem, e principalmente, os mais fracos podem ser excluídos do debate democrático. Mas não é o caso, porque o preso não seria o mais fraco se incluído nas conjecturas políticas. Nem o preso nem o futuro criminoso. Nilo Batista viu nos jovens prestes a serem alistados no tráfico de entorpecentes: "os mais brilhantes, os mais espertos, são o que estão ali. Este tesouro está sendo chacinado” (2003, p. 33); E Alvino Augusto de Sá de forma semelhante: "existe no infrator uma pessoa vocacionada a ser forte, consciente, vocacionada para participar da assembleia dos homens" (2010, p. 160).

Foi mais ou menos o que José Ingenieros disse, contrario sensu, em $O$ homem mediocre (1996), sobre os que "servis e acanhados pavoneiam-se honestos como se a incapacidade para o mal pudesse, em algum caso, se confundir com a virtude [...] tipo de homem que nos rodeia aos milhares" (p. 38). O filósofo argentino é duro contra a mesmice social, tem aversão aos dogmas e aos dogmáticos que falseiam "valores na consciência social; vivem na mentira, comem dela, semeiam-na, regam-na e a colhem" (p. 51), demonstra admiração pela iniciativa de ideais, pela coragem do ser humano que tem sonhos e se conduz por sentimentos independentemente da domesticação social. Em Ingenieros o recalque do ódio é a hipocrisia e os mediocres preferem a dissimulação ao enfrentamento das situações que podem prejudicá-los:

\footnotetext{
"preferem a maledicência surda à calúnia violenta. Sabendo que esta é criminosa e arriscada, optam pela primeira, cuja infâmia é sub-reptícia e sutil. Uma é audaz, a outra é covarde. O caluniador desafia o castigo, se expõe; o maledicente dele se esquiva. Um se afasta da mediocridade, é anti-social, tem coragem de ser delinquente; o outro é covarde e é encoberto pela cumplicidade de seus pares, mantendo-se na penumbra" (1996, p. 67).
}

A fascinação que os criminosos exercem na população é um exemplo de que eles não são só depositários de certo aspecto negativo de nós mesmos, mas também que neles há algo que exaltamos. Grandes criminosos da TV e do cinema com suas paixões e emoções livres em 
todos os sentidos, seja do mal ou do bem, tornam-se ícones. Os próprios super-heróis têm muito de violação. Significam a quebra de regras do Estado, a superação do medo que nos acompanha na rotina do dia a dia.

O que essas observações ensinam, todavia, não é que o criminoso ou o preso são melhores que ninguém, mas simplesmente que eles não são piores. Todos nós seres humanos temos nossos limites e somos mais sensíveis a circunstâncias diferentes. Na vida de qualquer um há sonhos e desejos que muitas vezes não são negociáveis. $\mathrm{O}$ episódio criminoso não pode decretar uma anormalidade. E, dentro do assunto que nos interessa, não podemos deixar de reconhecer que é preciso coragem e força para se arriscar à violação, e é essa espontaneidade que tem faltado e é interessante para o debate democrático.

Em um diálogo, quem tem medo de falar não é muito útil, não ajuda no avanço da conversa. Contudo, quem não teve medo de agir, com certeza nunca terá medo de falar. A diferença é que para agir não se necessita de muito, a força física somada a qualquer instinto pode bastar, enquanto para falar se carece de instrumentos de fala, consciência e integração no mundo da linguagem em que se está inserido. Dando-se condições de fala a quem não tem medo de agir teremos um grande e corajoso interlocutor.

É preciso repisar que quando se está falando de consciência política não pretendemos nenhuma doutrinação, mas principalmente uma autoconsciência política. A capacidade de se perceber como agente de mudança social deve ser possibilitada a todos nós. Neste ponto a proposta de Alessandro Baratta é tentadora por seguir no caminho da mudança de práticas institucionais, visto que somente a prática ensina o agir democrático. Desde os tribunais às prisões há necessidade desse diálogo em que temos insistido quase como sinônimo de democracia.

Podemos recorrer à pedagogia do oprimido, de Paulo Freire, e dizer que esta deve "ser forjada com ele e não para ele, enquanto homens ou povos, na luta incessante de recuperação de sua humanidade” (2011, p. 43) (Grifo no original). Por isso a educação para a consciência do professor pernambucano passa por um "diálogo crítico e libertador", tendo a "domesticação" do oprimido, na qual se incluem perfeitamente os artifícios ressocializadores, como sinônimo de "antidiálogo" (Idem, p. 72). 
Por fim, continuamos não acreditando no cárcere como meio para qualquer dos fins que a história já propôs. O seu conteúdo de pura exclusão seletiva e fortuita salta aos olhos. Mas se ele existe e ainda se mantém como instituição política, não se pode negar aos que entram nesse estabelecimento estatal a consciência da razão de seu sofrimento, nem que seja para permitir também a eles concluir sobre a falência da pena de prisão. 


\section{CONSIDERAÇÕES FINAIS}

De tudo pode ser acusado este trabalho, de exageros ou de julgamentos equivocados, menos de ele não ter sido escrito com liberdade. Alguns trechos estão em forma de desabafo, outros demonstram sério desânimo, e talvez grande parte tenha se afastado realmente do conceito tradicional de ciência. Quanto a esta última observação, nos defendemos utilizando a ideia de pós-modernidade e de aceitação de que a ciência de hoje deve conviver com as dúvidas inerentes à complexidade da natureza humana, mas de uma forma geral chegamos ao fim com a sensação de termos satisfeito e exaurido a proposta inicial de pesquisa.

Por certo tivemos limitações, porque circunscritos a um tema. Com certeza também novas ideias surgirão e, encerrado o texto, não poderão mais ser incluídas. Mas, já que falamos tanto de diálogo, tal constatação é inerente ao processo de criação, ao processo do pensamento que se constitui em uma dialética interminável. Portanto, não achamos que tudo foi dito e encerrado, sentimos apenas termos esgotada a primeira palavra no início de um diálogo que pode continuar sendo travado na própria reflexão do autor ou frente às críticas do leitor.

Assim, quando chegamos ao momento de concluir, percebemos que as conclusões se espalharam durante todo o texto e que, na verdade, não são conclusões, no sentido de definição que o termo carrega. Chamamos de conclusões somente por não termos encontrado outra palavra para definir o estado de nossa incapacidade de prosseguir no raciocínio, o limiar de nosso pensamento. Conclusão é até onde conseguimos chegar em determinado momento e em determinadas circunstâncias.

Aliás, esse é um óbice que entendemos diretamente ligado ao tema prisão. Qualquer discussão em torno dessa forma de punir sempre sofrerá o contágio de sua irracionalidade. $\mathrm{O}$ cárcere não aceita conclusões, porque o cárcere é o abandono da própria racionalização.

Sinceros desde o início a respeito de nossa ideia sobre o mal que é a prisão para a sociedade, procuramos intercalar nossas observações sobre regras de direito com a representação que possuímos da prisão. Achamos importante tal procedimento porque falar de direito penal, e principalmente de execução penal, sem realçar constantemente o que o ordenamento jurídico tem de desumano e fantasioso, é contribuir para a perpetuação do arbítrio. 
É chegada a hora de a ciência do direito assumir toda a repugnância que o cárcere causa, de abrir espaços para expressões de asco e de terror que despertam a visão das celas imundas, insalubres e promíscuas de nossas prisões, com nossos semelhantes, seres humanos amontoados, alimentando-se, dormindo em pé ou uns sobre os outros durante anos. E o que parece exagero em tal manifestação só parece porque o cárcere está distante, valendo aqui a máxima citada por Adorno de que "somente o exagero consegue veicular a verdade" (1995, p. 44).

Os pensadores pesquisados neste fazem parte da história do direito penal, ajudaram a construir o conhecimento que se tem hoje da prática punitiva do Estado, e em suas obras muitas vezes são encontradas expressões negativas sobre o cárcere. Todavia, estas ficaram para trás, foram silenciadas em nome de uma ordem jurídica que deve permanecer íntegra, ao menos no papel. Insistir na dicotomia existente entre a realidade do cárcere e a ficção da lei, é obrigação de todos que têm compromisso para com a verdade.

As dúvidas, inúmeras vezes esboçadas pelos precursores, e propositalmente exploradas neste trabalho, demonstram que a certeza do direito não se construiu cientificamente justamente porque houve o esquecimento de tais dúvidas. Se "o prosseguimento de um objetivo impossível do ponto de vista histórico e social é inteiramente contrário a uma visão científica do mundo" (REICH, 2001, p. 223), retornar às dúvidas dos textos originais é primordial para demonstrar nunca ter havido uma meta decretada, e que a verdadeira meta científica está em admitir a constante possibilidade de alteração da própria meta.

No entanto, quando estivemos especificamente falando da interpretação jurisprudencial, esforçamos-nos em apontar saídas lógicas para determinados dispositivos e regras jurídicas. Ainda que a inutilidade do cárcere nos indique seja qualquer interpretação sempre mais lógica se for feita no sentido de menos encarceramento, nossa análise tentou buscar outros argumentos que, dentro da limitada sistemática do ordenamento, sejam mais condizentes com os seus próprios ditames.

As duas primeiras premissas deste trabalho se confirmaram. Primeiramente a de que o termo ressocialização nunca resultou de um dado empiricamente comprovado. Nasceu no contexto de um ideal humanizador das prisões e acabou servindo mais como legitimador do 
que como motivo de efetiva reforma. Subterfúgio, reduzido a instrumento de retórica, para convencer a sociedade e o Estado de que era necessário investir na prisão, melhorando-a, mas, como consequência, sustentando-a.

A política criminal dos últimos anos é exemplo do quanto a prática punitiva sabe da ineficácia da prisão para qualquer tipo de reeducação. $\mathrm{O}$ encarceramento puro e simples é a regra, a construção de penitenciárias de segurança máxima cada vez mais distantes da cidade, o abandono do pouco que havia de assistência ao preso, a inexistência de estabelecimentos penais para sanções a serem cumpridas em semiliberdade, são circunstâncias cada vez mais evidentes. Por isso não nos ativemos aos trabalhos de criminologia que comprovam quanto ganha terreno a política penitenciária excludente, a qual há muito abandonou qualquer ação ressocializadora no sentido que advogavam todos os reformadores da história.

E para os fins deste trabalho não se fazia necessário mesmo falar sobre o desgaste do ideal ressocializador, pois o que demonstramos na prática judicial foi justamente o contrário: o uso demasiado do termo ressocialização pelos tribunais brasileiros, como se a atividade ressocializadora do cárcere estivesse em pleno apogeu, como se se tratasse de um ideal recente para o direito, passível de ser usado como argumento de justiça.

As críticas ficaram igualmente espalhadas no decorrer do texto, quando foram analisadas algumas regras penais e suas interpretações, mas pode ser ressaltado o contraste que é um tribunal agravar a pena de um cidadão com base no argumento ressocializador. Tais decisões falam por si mesmas, a falta de vínculo com a realidade é clara, mas procuramos propor outras interpretações que dessem maior coerência à aplicação de cada regra examinada, tendo como principais as seguintes:

a) O regime inicial da pena, estabelecido com base nos parâmetros do art. 59 do Código Penal, não pode ser fixado de forma mais grave sob o argumento de que assim se está fazendo para fins de ressocialização;

b) A remição (art. 126 da LEP) é direito a ser concedido ao preso quando este não trabalha por falta de atividade que deveria ter sido ofertada pelo Estado (remição ficta é termo usado para desprestigiar, e assim negar, direito evidentemente previsto em lei); 
c) A progressão de regime (art. 112 da LEP), ao ser analisada sem levarmos em conta o ideal ressocializador, prestigiando-se os critérios mais objetivos possíveis, em nome igualmente do princípio da legalidade, deve ser concedida para qualquer dos regimes posteriores, de acordo com o tempo de pena do sentenciado (Progressão per saltum é igualmente termo depreciativo utilizado para agravar a pena do sentenciado);

d) $\mathrm{O}$ exame criminológico é exame inicial para a individualização administrativa da pena privativa de liberdade (art. $8^{\circ}$ da LEP), sendo inviável vedar ou obstaculizar direitos surgidos posteriormente no curso da execução penal com base em dados de natureza subjetiva colhidos por tal exame (a exigência de exame criminológico tem sido feita para retardar direitos presentes na execução penal).

Estas foram, de forma bem sucinta, as principais questões legais analisadas no curso do texto. Entendemos também que estas questões constituem pontos primordiais para o sistema penitenciário, pois se relacionam com temas da fundamental importância no maior tempo de encarceramento. Um regime mais grave, a negação de remição, vários obstáculos à progressão, são sempre originados de decisões judiciais que acabam obstruindo a porta de saída do sistema penitenciário.

Então, a segunda premissa, a de que o termo ressocialização é usado como instrumento encarcerador, também ficou evidenciada. E tal constatação é mais grave do que parece, pois um termo que nasceu como instrumento humanizador acaba servindo de justificativa para suavizar posicionamentos de lei e ordem. O contraste é evidente: enquanto a prática penitenciária abandona o ideal de ressocialização e assume as prisões como depósitos, os tribunais, ignorando tal realidade, continuam usando o termo ressocialização para encarcerar.

Diante deste quadro fica claro que todo discurso reformista da prisão é perigoso. A não ser que decretemos o fim da história, aceitando a ideia de a evolução humana terminar com a prisão, abandonando a busca por alternativas, todo discurso de reforma pode ser usado como discurso renovador do cárcere ou, ao menos, como renovador da atitude encarceradora.

A ideia inicial deste trabalho era a de verificar se, com a exclusão do ideal ressocializador, poderíamos favorecer a concepção de diálogo que deve ser inerente ao direito. Neste ponto a impressão é de termos falhado, e assim parece por dois motivos: primeiro 
porque a prática judicial tem se mostrado tão indiferente à realidade penitenciária, que parece não fazer diferença a justificativa que se dê ao encarceramento, contanto que se encarcere; segundo porque o problema pareceu ser insolúvel a nível de superestrutura estatal, pois sendo o judiciário aquele que diz o direito um poder hierarquizado, onde a disciplina se dá em detrimento de práticas democráticas, dificilmente será do seu interior que poderá sair alguma mudança de postura.

Diante dessa perspectiva, a nossa proposta, de que o princípio da dignidade da pessoa humana deveria substituir o ideal de ressocialização nas práticas jurisdicional e penitenciária, não parece ter muita força, pois a conduta de encarcerar demonstra sobreviver a qualquer argumento. A Constituição Federal está aí para demonstrar que nem se colocando a dignidade da pessoa humana como fundamento do Estado Democrático de Direitos as práticas políticas deixam de seguir no sentido de mais indiferença para com o ser humano.

Todavia, no sentido de diálogo que deve ter o direito, mantemos a nossa proposição, pois o princípio da dignidade da pessoa humana sempre será argumento de uso muito mais difícil do que o ideal de ressocialização para o fim de encarcerar. Repetindo o que já dissemos, não seria fácil para o juiz assim se manifestar: regrido para o regime fechado, o cidadão $x$, em prol da dignidade da pessoa humana. Se para a ressocialização tudo é possível, para a dignidade humana não. O ruído na comunicação fica mais evidente se o judiciário se exprime na forma acima citada.

Importa reafirmar igualmente o que ficou implícito já no título deste trabalho: o ideal de ressocialização é verdadeiramente incompatível como o princípio da legalidade. O ideal de ressocialização está estreitamente ligado ao direito penal do autor, onde preponderam preconceitos e sentimentos de quem julga em prejuízo da objetividade e clareza do direito de quem é julgado.

É nítida a separação entre as fases do processo de conhecimento e do processo de execução, quando no primeiro há a prevalência do direito penal do fato e no segundo do direito penal do autor, enquanto, em um Estado de Direito, não deveria haver espaços para um direito penal baseado em condutas que não estão previamente, claramente e objetivamente previstas em lei. 
Por fim, quanto à proposta de se adotar o conceito de reintegração social apresentado por Alessandro Baratta, não nos surpreendemos de que a maior parte de suas sugestões foi no campo da prática penitenciária, muito embora o objetivo do professor italiano tenha sido o de apresentar uma reinterpretação do termo ressocialização. Utopia ou não, qualquer ação para a melhora na qualidade do encarceramento é viável; o prejudicial é este tipo de ação passar a integrar um discurso que possa fortalecer a conduta encarceradora.

Interessante observar como quando se começa a falar do cárcere propriamente dito há um afastamento instantâneo da questão jurisprudencial. Curioso como duas práticas que deveriam estar diretamente relacionadas, vivem mundos diametralmente opostos. O direito, para manter o seu aspecto científico, trata a prisão friamente, não reconhecendo o mal em que ela verdadeiramente se constitui. Enquanto isto, a prática penitenciária segue atônita, subordinada às diretrizes do diretor ou governador do momento, com espaços para o exercício de toda espécie de poder sobre o encarcerado.

Quanto à ideia de reintegração social apesar do cárcere, os seus méritos são óbvios, mas o cárcere é, com efeito, o que causa maior pesar para qualquer procedimento de aproximar o excluído da sociedade. Há que se ter cuidado, pois "se faz um grande mal pretendendo realizar uma ideia boa em condições próprias para desacreditá-la"231 (ARENAL, 1895-b, p. 341). Assim, deve ficar bem claro que inclusão social não se faz por intermédio do cárcere e, como observamos, dificilmente também se fará apesar dele.

Mesmo assim examinamos certas características das pessoas envolvidas com o cárcere e suas funções. Pretendemos com isso avaliar as possibilidades de comunicação, elemento central do conceito de reintegração, de onde inferimos diversas dificuldades, mas a principal foi a objeção em se reconhecer o aprisionamento como conduta política.

Se o judiciário encarcera sob a fachada do cientificismo, desconhecendo que o próprio discurso científico é um discurso de poder, pois desmerece todos os outros, hierarquizando o saber na sociedade e afastando-se cada vez mais da realidade onde se produz conhecimento diariamente, na prática penitenciária a cisão se dá ainda mais pela grade. Quem está do lado de

\footnotetext{
${ }^{231}$ No original: "se hace un gran mal pretendiendo realizar una idea buena en condiciones proprias para desacreditarla” (ARENAL, 1895-b, 341).
} 
lá da grade é diferente, seja porque é criminoso, culpado ou doente, e a dificuldade de se ver o sentenciado como semelhante capaz de diálogo está principalmente nessa distinção.

Só a consciência política pode dar a capacidade de crítica necessária para se abandonar a concepção de que essa diferença é natural. Enquanto juízes, promotores ou carcereiros continuarem pensando a realidade com os parâmetros que as leis lhes dão, o condenado será sempre um estranho. O respeito pelo preso como cidadão, sujeito de direitos, passa pelo seu reconhecimento como igual.

De nada adiantaria a defesa da substituição do discurso ressocializador pela consideração da dignidade da pessoa humana se não incluíssemos, no respeito à dignidade, a emancipação da pessoa humana em todos os sentidos e, principalmente, no político. Pois, caso contrário, o respeito à dignidade da pessoa humana teria um aspecto unilateral, de piedade apenas, impedindo que a pessoa se torne parte de sua própria emancipação e, assim, poder se colocar verdadeiramente como sujeito capaz de exigir seus direitos, ou seja, como sujeito de direitos. 


\section{Referência:}

ABI-ACKEL, Ibrahim. Novas dimensões da pena: relatório e conclusões da Comissão Parlamentar de Inquérito destinada a proceder ao levantamento da situação penitenciária do País. Brasília: Câmara dos Deputados, 1990.

ADORNO, Theodor W. Actualidad de la filosofia. Barcelona: Paidós, 1991.

. A industria cultural. In: Comunicação e industria cultural. e indústria cultural: leituras de análise dos meios de comunicação na sociedade contemporânea e das manifestações de opinião pública, propaganda e cultura de massa nessa sociedade. São Paulo: Ed. Nacional, 1978, p. 287-295.

. Educação e emancipação. Rio de Janeiro: Paz e Terra, 1995.

. Mínima moralia. Portugal: Edições 70, 2001.

AGUILERA, Abel Téllez. Los Sistemas Penitenciários y sus prisiones: Derecho y realidad. Madri, Espanha: EDISOFER. 1998.

AGUIRRE, Carlos. Cárcere e sociedade na América Latina, 1800-1940. In: História das prisões no Brasil. Vol. 1. Rio de Janeiro: Rocco, 2009, p. 35-77.

AKHTAR, Salman. Desumanização: origens, manifestações e soluções. In: Violência ou diálogo?: reflexões psicanalíticas sobre terror e terrorismo. São Paulo: Perspectiva, 2008, p. 123-137.

ALBACETE, Fernando J. Burillo. El Nacimiento de la Pena Privativa de Liberdad. Madri, Espanha: 1999.

ALBERGARIA, Jason. Das penas e da execução penal. 3. ed. Belo Horizonte: Del Rey, 1996.

ALEXANDER, Michelle. The new Jim Crow: mas incarceration in the age of colorblindness. New York, EUA: The New Press, 2012.

ALTAVILA, Jayme de. Origem dos Direitos dos Povos. 6. ed. São Paulo: Ícone, 1989.

ANCEL, Marc. A Nova defesa social. 2 ed. Rio de Janeiro: Forense, 1971.

ANDRY, R. G. The problem of teamwork: some contributions from social psychology. In: Criminology in transition, essays in honor of Hermann Mannheim. Londres, Inglaterra: Butler \& Tanner Ltd, 1965, p. 127-152.

ANTUNES, Mitsuko Aparecida Makino. A psicologia no Brasil: leitura histórica sobre sua constituição. 5. ed. São Paulo: EDUC, 2007.

ARANHA, Altair J. Dicionário brasileiro de insultos. Cotia, SP: Atelié, 2002.

ARENAL, Concepción. Estudios penitenciarios. Vol 1. Madri, Espanha: Librería de Victoriano Suárez, 1895-a.

b.

. Estudios penitenciarios. Vol 2. Madri, Espanha: Librería de Victoriano Suárez, 1895- 
ARTIACH, Pilar Fernández. El trabajo de los internos em estabelecimientos penitenciarios. Valência, Espanha: Tirant lo Blanch, 2006.

ARNAOUTOGLOU, Ilias. Leis da antiga Grécia. São Paulo: Odysseus, 2003.

ASSIS, Machado. Bons dias! \& notas semanais. In: Obras Completas. São Paulo: Editora Globo, 1997.

AZCÁRATE, Gumersindo D. Doña Concepción Arenal em el derecho e la sociologia. Madri, Espanha: Librería de Victoriano Suárez, 1894.

BANNER, Stuart. The death penalty: an American history. Cambridge, EUA: Harvard University Press, 2003.

BARATTA, Alessandro. Criminología y sistema penal: compilación in memorian. Buenos Aires, Argentina: Editorial B de F, 2006. $113-132$

Ética e pós-modernidade. In: Ética na comunicação. Rio de Janeiro: Mauad, 1995, p.

BARRETO, Tobias. Estudos de filosofia. Rio de Janeiro: Record, 1990.

BARROS, Carmem Silvia de Moraes. A individualização da pena na execução penal. São Paulo: Ed. Revista dos Tribunais, 2001.

BARROS, Celso. Parecer da Comissão de Constituição e Justiça precedido de Relatório e voto do Relator da matéria, Deputado Celso Barros. In: Execução Penal, Lei 7.210, de 11-784: texto de lei anotado e indexado, anteprojetos, histórico (tramitação legislativa). Brasília: Senado Federal, 1985.

BARROS, Fabrício Barbosa. Pode a Lei Maria da Penha proteger os homens? A marca feminina no poder geral cautelar do processo penal brasileiro. Disponível em: $<$ www.ibccrim.org.br>. Acesso em: 12 mar. de 2011.

BATISTA, Nilo. Introdução crítica ao direito penal brasileiro. 8 ed. Rio de Janeiro: Revan, 2002.

. Punidos e mal pagos: violência, justiça, segurança pública e direitos humanos no Brasil de hoje. Rio de Janeiro: Revan, 1990.

. Todo crime é político. Revista Caros Amigos. São Paulo: Editora Casa Amarela, n.

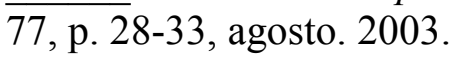

BAUMAN, Richard A. Crime and punishment in ancient Rome. Londres, Inglaterra: Routledge, 2004.

BAUMAN, Zygmunt. Globalização: consequências humanas. Rio de Janeiro: Jorge Zahar, 1999.

. Vidas desperdiçadas. Rio de Janeiro: Jorge Zahar, 2005.

BECCARIA, Cesare Benesana. Dei delitti e delle pene. Paris, França: Cazin, 1786.

. Dos delitos e das penas. Trad. Paulo M. Oliveira. Bauru: Edipro, 2003.

. Dos delitos e das penas. 2 ed. Trad. J. Cretella Jr e Agnes Cretela. São Paulo: Revista dos Tribunais, 1999. 
BECK, Ulrich. Liberdade ou capitalismo: Ulrick Beck conversa com Johannes Willms. São Paulo: Editora UNESP, 2003.

BENDER, John. Imagining the penitentiary: fiction and the architecture of mind in eighteenth-century England. Chicago, EUA: The University of Chicago Press, 1987.

BENETI, Sidnei Agostinho. Execução penal. São Paulo: Saraiva, 1996.

BENJAMIN, Walter. Sobre arte, técnica, linguagem e política. Lisboa, Portugal: Relógio D’Água Editores, 1992.

BENTHAM, Jeremy. O Panóptico. Belo Horizonte: Autêntica, 2000.

. Teoria das penas legais e tratado dos sofismas políticos. Leme, SP: EDIJUR, 2002.

BEAUMONT, Gustave de. On the penitentiary system in the United States and its application in France with na appendix on penal colonies and also statistical notes. Reprints from the collection of University of Toronto: 2012.

BILLOUET, Pierre. Foucault. São Paulo: Edição Liberdade, 2003.

BITTAR, Eduardo C. B. O direito na pós-modernidade e reflexões frankfurtianas. Rio de Janeiro: Forense Universitária. 2009.

BITENCOURT, Cezar Roberto. Falência da pena de prisão: causas e alternativas. São Paulo: Editora Revista dos Tribunais, 1993.

. Tratado de direito penal. 14. ed. São Paulo: Saraiva, 2009.

BLOMBERG, Thomas G.; LUCKEN, Karol. American penology: a history of control. 2 ed. New Jersey, EUA: Transaction Publishers, 2010.

BOBBIO, Norberto. A era dos direitos. Rio de Janeiro: Campus, 1992.

BORDIEU, Pierre. A má-fé da instituição. In: A miséria do mundo. 8 ed. Petrópolis, RJ: Vozes, 2011, p. 243-245.

BOTELHO, João Bosco. Medicina e religião. Manaus: Valer, 2005.

BURFEIND, James W.; BARTUSCH, Dawn Jeglum. Juvenile delinquency: an integrated approach. Massachusetts, EUA:World Headquarters, 2011.

BRAGA, Ana Gabriela Mendes; BRETAN, Maria Emília Accioli Nobre. Teoria e prática da reintegração social: o relato de um trabalho crítico no âmbito da execução penal. In:

Criminologia e os problemas da atualidade. São Paulo: Atlas, 2008, p. 255-275.

BROWN, James Baldwin. Memoirs of the public and private life of John Howard, the philanthropist. 2 ed. Londres, Inglaterra: Printed for Thomas and George Underwood, 1823.

BRUNO, Aníbal. Direito penal: parte geral. 4 ed. Rio de Janeiro: Forense, 1984.

CALAMANDREI, Piero. Eles, os juízes, vistos por nós, os advogados. 7 ed. Rio de Janeiro: Clássica Editora, [1985].

CALVANESE, Ernesto. Pena riabilitativa e mass-media: uma relazione controversa. 2. ed. Milão, Itália: FrancoAngeli, 2004. 
CAMARGO, Antônio Luis Chaves. CAMARGO, Antônio Luís Chaves. Imputação objetiva e direito penal brasileiro. São Paulo: Cultural Paulista, 2002-a.

- Direitos humanos e direito penal: limites da intervenção estatal no estado democrático de direito. In: Estudos criminais em homenagem a Evandro Lins e Silva. São Paulo: Método, 2001. p. 73-80.

. Sistema de penas, dogmática jurídico-penal e política criminal. São Paulo: Cultura Paulista, 2002-b.

CAMUS, Michel. Os crimes do Marquês de Sade. In: Enciclopédia da luta contra o crime. São Paulo: Ed. Abril, 1974, p. 1210-1232.

CARMENA, Manuela. Prólogo. In: El visitador del preso. Madri, Espanha: ACOPE, 2000, p. I-VIII.

CARVALHO, Salo de. Memória e esquecimento nas práticas punitivas. In: Criminologia e sistemas jurídicos-penais contemporâneos. Porto Alegre: EDIPUCRS, 2008, p. 57-92.

. O papel da perícia psicológica na execução penal. In: Psicologia jurídica no Brasil.

2. ed. Rio de Janeiro: NAU Ed., 2009, p. 141-155

. Penas e garantias. 3 ed. Rio de Janeiro: Lumen Juris, 2008.

CASTILHO, Ela Wiecko V. Controle da legalidade na execução penal. Porto Alegre: Sérgio Antônio Fabris Editor, 1988.

CASTORIADIS, Cornelius. Janela sobre o caos. Aparecida, SP: Ideias \& Letras, 2009.

CASTRO, Lola Aniyar de. Matar com a prisão, paraíso legal e o inferno carcerário: os estabelecimentos "concordes, seguros e capazes. In: Depois do grande encarceramento. Rio de Janeiro: Revan, 2010, p. 85-106.

CAYLEY, David. The expanding prison: the crisis in crime and punishment and the search for alternatives. Toronto, Canadá: House of Anansi Press, 1998.

CERNICCHIARO, Luiz Vicente. Questões penais. Belo Horizonte: Del Rey, 1998.

CENNI, Franco. Italianos no Brasil. 3 ed. São Paulo: Editora da Universidade de São Paulo, 2003.

CERVINI, Raúl. Os processos de descriminalização. São Paulo: Editora Revista dos Tribunais, 1995.

CHRISTIE, Nils. Uma sensata cantidad de delito. Buenos Aires, Argentina: Editores del Puerto, 2004.

CIAPPI, Silvio; COLUCCIA, Anna. Giustizia criminale. Retribuzione, riabilitazione e riparazione: modelli e strategie di intervento penale a confronto. Milão, Itália: Franco Angele, 1997.

COMBESSIE, Philippe. Definindo a fronteira carcerária: estigma penal na longa sobra da prisão. In: Discursos sediciosos: crime, direito e sociedade. Ano 8, nº 13, 2003, p. 131-146.

CONDE, Francisco Muñoz. El tratamiento penitenciario. In: Derecho penitenciario e democracia. Sevilha, Espanha: Funcadación El Monte, 1994, p. 197-208. 
CONSELHO FEDERAL DE PSICOLOGIA. A prática profissional dos (as) psicólogos no Sistema Prisional. Brasília: CFP, 2009.

COSTA, Helena Regina Lobo da. A dignidade humana: teorias de prevenção geral positiva. São Paulo: Ed. Revista dos Tribunais, 2008.

COSTA Júnior, Paulo José da. Curso de direito penal. 10. ed. São Paulo: Saraiva, 2009. . Código Penal anotado. São Paulo: Perfil, 2008.

CLEAR, Todd R.; COLE, George F.; REISIG, Michael D. American corrections. 8 ed. Califórnia, EUA: Thomson Wadsworth, 2009.

COHEN, David. A fuga de Freud. Rio de Janeiro: Record, 2010.

COSTA, Álvaro Mayrink da. Criminologia. Vol. I e II, Tom. I, 3. ed. Rio de Janeiro: Forense, 1982.

CUNHA, Sérgio Sérvulo da. A emenda constitucional $n^{\circ} 45$ (reforma do judiciário). Revista Latino-Americana de Estudos Constitucionais. n. 6, p. 649-664, julho/dezembro. 2005.

D’AMBROSIO, Ubiratan. Transdisciplinaridade. São Paulo: Palas Athena, 1997.

DAVIS, Angela Y. Are prisons obsolete? New York, EUA: 2003.

DIAS, José de Figueiredo; ANDRADE, Manuel da Costa. Criminologia: o homem delinquente e a sociedade criminógena. Coimbra, Portugal: Ed. Coimbra, 1997.

DELUEZE, Gilles. A ilha deserta: e outros textos. São Paulo: Iluminuras, 2006.

. Conversações. São Paulo: Ed. 34, 1992.

DIDIER, Eribon. Michel Foucault y sus contemporáneos. Buenos Aires: Nueva Visión, 1995.

DI TULLIO, Benigno. La constituzione delinquenziale nella etiologia e terapia del delitto. Roma, Itália: Anonima Romana Editoriale, 1929

DOTTI, René Ariel. Bases e alternativas para o sistema de penas. São Paulo: Editora Revista dos Tribunais, 1998.

. Curso de direito penal: parte geral. Rio de Janeiro: Forense, 2001.

. Os direitos humanos do preso e as pragas do sistema criminal. Revista Brasileira de Ciências Criminais, São Paulo, ano 11, n. 42, p. 264-279, jan/mar. 2003.

O sistema geral das penas. In: Penas restritivas de direitos: críticas e comentários às penas alternativas: Lei 9.714, de 25.11.1998. São Paulo: Editora Revista dos Tribunais, 1999, p. $65-105$.

DUBY, G. A Europa na idade média. São Paulo: Livraria Martins Fontes Ed., 1988.

DURKHEIM, Émile. Da divisão do trabalho social. São Paulo: Martins Fontes, 1999.

ÉSQUILO. Prometeu acorrentado. In: Teatro Grego. Clássicos Jackson, vol. XXII. Rio de Janeiro: 1953, p. 3-41.

ESTEVES, João Pissarra. Espaço público e democracia: comunicação, processo de sentido e identidade social. São Leopoldo, RS: Editora UNISINOS, 2003. 
EURÍPEDES. Alcestes. In: Teatro Grego. Clássicos Jackson, vol. XXII. Rio de Janeiro: 1953, p. $172-226$.

FABBRI, Carlo. E fece buona morte: memories sui condannati alla pena capitale a Firenze in due "Libre Neri" inediti del settecento. Florença, Itália: Aska Edizioni, 2004.

FERLA, Luís. Feios, sujos e malvados sob medida: a utopia médica do biodeterminismo. São Paulo: Alameda, 2009.

FERNANDES, Newton; FERNANDES, Valter. Criminologia Integrada. São Paulo: Editora Revista dos Tribunais, 1995.

FERNÁNDEZ-ARMESTO, Felipe. Verdade: uma história. Rio de Janeiro: Record, 1997.

FERREIRA, Carlos Lélio Lauria. Lei de execução penal: em perguntas e respostas. Rio de Janeiro: Forense, 2005.

; VALOIS, Luís Carlos. Sistema Penitenciário do Amazonas: história, evolução, contexto atual. Curitiba: Juruá, 2010.

FERRI, Enrico. Criminal sociology. Londres, Inglaterra: Echo Library, 2007

. La scuola criminale positiva: confernza del prof. Enrico Ferri nella Università di Napoli. Nápoles, Itália: Enrico Detken Editore, 1885.

. Princípios de direito criminal. 2 ed. Campinas, SP: Bookseller, 1999.

FIGUEIREDO, Luís Cláudio M. Revisitando as psicologias: da epistemologia à ética das práticas e discursos psicológicos. 5 ed. Petrópolis/RJ: Vozes, 2009.

FOUCAULT, Michel. A verdade e as formas jurídicas. 3 ed. Rio de Janeiro: NAU Editora, 2009.

. Em defesa da sociedade. São Paulo: Martins Fontes, 1999.

. Microfisica do poder. 21 ed. Rio de Janeiro: Edições Graal. 2005.

. Os anormais. São Paulo: Martins Fontes, 2001.

. Por uma vida não-fascista. Org. Coletivo Sabotagem. s.l.: Sabotagem, 2004.

. Segurança, território, população. São Paulo: Martins Fontes, 2008.

. Vigiar e punir: nascimento da prisão. 18. ed. Petrópolis/RJ: Vozes, 1998.

FRANÇA, R. Limongi. Hermenêutica jurídica. 9. ed. São Paulo: Editora Revista dos Tribunais, 2009.

FRANCO, Alberto Silva. Crimes hediondos: notas sobre a Lei 8.072/90. São Paulo: Ed. Revista dos Tribunais, 1994.

; et. al. Código penal e sua interpretação jurisprudencial. 5. ed. São Paulo: Editora

Revista dos Tribunais, 1995.

FREIRE, Paulo. Pedagogia do oprimido. Rio de Janeiro: Paz e Terra, 2011.

FREUD, Sigmund. O futuro de uma ilusão. In: Edição Standard Brasileira das Obras Completas (ESB). Vol. XXI. Rio de Janeiro: Imago, 1980, p. 15-80. 
. Por que a guerra? In: Edição Standard Brasileira das Obras Completas (ESB). Vol. XXII. Rio de Janeiro: Imago, 1977, p. 241-259

FROMM, Erich. A revolução da esperança: por uma tecnologia humanizada. São Paulo: Círculo do livro, [1977].

- Psicoanálisis de la sociedad contemporânea. 6. ed. México: Fondo de Cultura Económica, 1964.

GABBIDON, Shaun L. Criminological Perspectives on Race and Crime. 2 ed. Nova York, EUA: Routledge, 2010.

GARAUDY, Roger. Do anátema ao diálogo. Rio de Janeiro: Paz e Terra, 1966.

GILISSEN, John. Introdução histórica ao estudo do direito. 2. ed. Lisboa, Portugal: Fundação Calouste Gulbenkian, 1995.

GIORDANI, Mário Curtis. Direito penal romano. Rio de Janeiro: Forense, 1982.

GOFFMAN, Erving. Manicômios, prisões e conventos. 7. ed. São Paulo: Editora Perspectiva, 2001.

GÓMEZ, Alfonso Serrano; MAÍLLO, Alfonso Serrano. La antroplogía criminal em la historia de la criminologia española. In: Universitas Vitae: homenaje a Ruperto Núñez Barbero. Salamanca, Espanha: Ediciones Universidad de Salamanca, 2007, p. 741-764.

GOMES, Mariângela Gama de Magalhães. O princípio da proporcionalidade no direito penal. São Paulo: Editora Revista dos Tribunais, 2003.

GOULART, José Alípio. Da Palmatória ao Patíbulo. Rio de Janeiro: Ed. Conquista, 1971.

GRAMATICA, Felippo. Principios de defensa social. Madri, Espanha: Editora Montecorvo, 1974.

GRAU, Eros Roberto. Ensaio e discurso sobre a interpretação/aplicação do direito. 4. ed. São Paulo: Malheiros, 2005. . O direito posto e o direito pressuposto. 7. ed. São Paulo: Malheiros, 2008.

GRECO, Luís. As regras por trás da exceção: reflexões sobre a tortura nos chamados "casos de bomba relógio”. Revista Brasileira de Ciências Criminais, São Paulo, ano 17, n. 78, p. 735, mai/jun. 2009.

GRECO, Rogério. Curso de direito penal. 11. ed. Rio de Janeiro: Impetus, 2009.

GREENBERG, David F. Crime and capitalism: readings in Marxist criminology. Philadelphia, EUA: Tample University Press, 1984.

GUASTINI, Riccardo. Das fontes às normas. São Paulo: Quartier Latin, 2005.

GUATTARI, Félix. Psicanálise e transversalidade: ensaios de análise institucional. Aparecida, SP: Ideias e Letras, 2004.

GUYAU, Jean-Marie. Crítica da ideia de sanção. São Paulo: Martins, 2007.

HADDAD, Jorge. Derecho Penitenciario: actividad delictual, responsabilidad y rehabilitacion progressiva. Buenos Aires, Argentina: Ciudad Argentina, 1999. 
HABERMAS, Jüngen. O discurso filosófico da modernidade. São Paulo: Martins Fontes, 2000.

HAGAN, Frank E. Introduction to Criminology: theories, methods, and criminal behaivior. 7 ed. California, EUA: SAGE Publications, 2011.

HAGGERTY, Kevin D. Making crime count. Toronto, Canadá: University of Toronto Press, 2001 .

HASSEMER, Winfried. Direito penal libertário. Belo Horizonte: Del Rey, 2007.

HEGEL, G. W. F. A sociedade civil burguesa. Lisboa, Portugal: Editorial Estampa, 1979.

HERMAN, Arthur. La Idea de decadência em la historia occidental. Barcelona, Espanha: Ed. Andrés Bello, 1998.

HODAPP, Axel. Resozialisierung im Strafvollzug - Gesetz und Wirklichkeit. Alemanha: GRIN Verlag, 2003.

HOWARD, John. The State of Prisions in England and Wale. Londres, Inglaterra: Printed by Willian Eyres, 1777.

HUNGRIA, Nelson; FRAGOSO, Heleno. Comentários ao código penal. Vol. 1. Tomo 1. 5. ed. Rio de Janeiro: Forense, 1977.

. Novas teorias e diretrizes do direito penal. In: Revista do Instituto dos Advogados Brasileiros, criminalidade e criminologia. Ano VII, n. 39, 1973, p. 29-39.

HULSMAN, Louk. Alternativas à justiça criminal. In: Curso livre de abolicionismo penal. Rio de Janeiro: Revan, 2004, p. 35-68.

- Temas e conceitos numa abordagem abolicionista da justiça criminal. In: Conversações abolicionistas: uma crítica do sistema penal e da sociedade punitiva. São Paulo: IBCCrim, 1997, p. 189-213.

JOHNSON, Charles. Uma história geral dos roubos e crimes de piratas famosos: a política interna, a disciplina de bordo, as façanhas e aventuras de 19 criminosos célebres da era de outro da pirataria (1717-1724). Porto Alegre, RS: Artes e Ofícios, 2004.

JUNG, Carl Gustav. A energia psíquica. Petrópolis, RJ: Vozes, 2002.

. A vida simbólica. 4 ed. Petrópolis, RJ: Vozes, 2008.

. O Eu e o inconsciente. 21 ed. Petrópolis, RJ: Vozes, 2008.

KAFKA, Franz. O processo. 4. ed. Lisboa, Portugal: Livros do Brasil, 1999.

KARAM, Maria Lúcia. Aplicação da pena: por uma nova atuação da justiça criminal. In: Revista Brasileira de Ciências Criminais. Ano 2, n. 6, abril-junho, 1994, p. 117-123

. Pela abolição do sistema penal. In: Curso livre de abolicionismo penal. Rio de Janeiro: Revan, 2004, p. 69-107.

KONDER, Leandro. Marxismo e alienação: contribuições para um estudo do conceito marxista de alienação. São Paulo: Expressão Popular, 2009.

LEAL, César Barros. Prisão: crepúsculo de uma era. 2. ed. Belo Horizonte: Del Rey, 2001. 
LEAL, João José. Direito penal geral. São Paulo: Atlas, 1998.

LYNCH. Michael J. Big prisons, big dreams: crime and the failure of America's penal sistem. New Jersey, EUA: Rutgers University Press, 2007.

LISZT, Franz Von. A idéia do fim no Direito Penal. São Paulo: Ridel, 2005.

LOMBROSO, Cesare. O homem delinquente. Porto Alegre: Ricardo Lenz Ed., 2001.

LOPES Jr., Aury. Direito processual penal e sua conformidade constitucional. Vol. I, 4. ed. Rio de Janeiro: Lumen Juris, 2009.

LOPES, Maurício Antônio Ribeiro. Princípio da legalidade penal. São Paulo: Editora Revista dos Tribunais, 1994.

LÓPEZ, Francisca Cano. La influencia del positivismo em la criminología y penalogía españolas: orígenes y primeros pasos de la prevención especial como fin de la punición. In: Mitologías y discursos sobre el castigo: historias del presente y posibles escenarios. Barcelona, Espanha: OSPDH, 2004, p. 61-69.

LYRA, Roberto. Direito penal científico. Rio de Janeiro: José Konfino Editor, 1974-a Direito penal normativo. Rio de Janeiro: José Konfino Editor, 1974-b.

MAIA Neto, Cândido Furtado. Direitos humanos do preso: lei de execução penal, Lei $n^{o}$ 7.210/84. Rio de Janeiro: Forense, 1998.

MANITA, Celina. O conceito de perigosidade: implicações para o diálogo interdisciplinar entre psicologia e direito penal. In: Sub judice, justiça e sociedade, no 22/23, jul/dez, 2001, p. $37-48$.

MANNHEIM, Hermann. Criminologia comparada. Vol. I. Lisboa, Portugal: Fundação Calouste Gulbenkian, 1984.

MAPELLI Cafferena, Borja. Principios fundamentales del sistema penitenciario español. Barcelona, Espanha: Editorial Bosch, 1983.

MARCÃO, Renato. Curso de execução penal. 4. ed. São Paulo: Saraiva, 2007.

MARTINS, Sergio Mazina. A lei e os homens: argumentos sobre o estatuto filosófico do direito de execução penal. In: Boletim IBCCrim, ano 8, nº 91, jun., 2000, p. 11-12.

MARX, Karl. O Capital: crítica da economia política. Vol 1. 3 ed. São Paulo: Nova Cultural, 1988.

. Glosas críticas marginais ao artigo "O rei da Prússia e a reforma social” de um prussiano. Rio de Janeiro: Expressão Popular, 2010.

MATEUS, Jaime Peña. Antecedentes de la prisión como pena privativa de liberdad em Europa hasta el siglo XVII. In: Historia de la prisión: teorias economicistas. Crítica. Madri, Espanha: Edisofer, 1997, p. 63-78.

MAYRINK da Costa, Álvaro. Criminologia. Vol I, Tomo II, 3 ed. Rio de Janeiro: Forense. 1982.

MAXIMILIANO, Carlos. Hermenêutica e aplicação do direito. Rio de Janeiro: Ed. Freitas Bastos, 1941. 
MAZZARELLO, Paolo. Il gênio e l'alienista: la strana visita di Lombroso a Tolstoj. Torino, Itália: Bollati Boringhieri, 1998.

MCHUGH, Eileen. Images of America: Auburn, correctional facility. Chicago, EUA: Arcadia Publishing, 2010.

MCSHANE, Marilyn D.; WILLIAMS, Frank P. Encyclopedia of American prisons. Nova York, EUA: Taylor\&Francis e-Library, 2005.

MELOSSI, Dario; PAVARINI, Massimo. Cárcere e fábrica: as origens do sistema penitenciário (séculos XVI-XIX). Rio de Janeiro: Revan, 2006.

MIOTTO, Armida Bergamini. Temas penitenciários. São Paulo: Editora Revista dos Tribunais, 1992.

MIRABETE, Júlio Fabbrini. Execução penal: comentários à Lei $n^{\circ} 7.210$, de 11-7-84. São Paulo: Atlas, 1997.

MORAES, Talvane M. de. Classificação e triagem dos perfis criminológicos: crime e doença mental. In: Anais do $1^{\circ}$ Encontro Nacional de Execução Penal. Distrito Federal: FAP/DF, 1998, p. 227-265.

MONTERO, Pedro Dorado. El derecho protector de los criminales. Tomo I. Madri, Espanha: Librería de Victoriano Suárez, 1915-a.

. El derecho protector de los criminales. Tomo II. Madri, Espanha: Librería de Victoriano Suárez, 1915-b.

MONTESQUIEU, Charles de Secondat, Baron de. O espirito das leis. São Paulo: Martins Fontes, 1996.

MORIN, Edgar. Ciência com consciência. 13. ed. Rio de Janeiro: Bertrand Brasil, 2010.

MOUFFE, Chantal. O regresso do político. Lisboa, Portugal: Gradiva, 1996.

MUAKAD, Irene Batista. Pena privativa de liberdade. São Paulo: Editora Atlas, 1996.

NABUCO, Joaquim. O abolicionismo. Rio de Janeiro: Nova Fronteira, 2000.

NALINI, José Renato. Pode o juiz melhorar a execução penal? In: Execução penal: visão do TACRIM-SP. São Paulo: Editora Oliveira Mendes, 1998, p. 135-144.

NEIVA, Gerivaldo. Como se começa de novo sem nunca ter começado antes? Disponível em: $<$ www.gerivaldoneiva.com>. Acesso em: 7 ago. de 2011.

NETTO, Alexandre Orsi. A falácia do in dúbio pro societate como princípio no processo de execução criminal. In: Boletim IBCCRIM. São Paulo: IBCCRIM, ano 17, n. 204, p. 14-15, nov., 2009

NEUMAN, Elías. El estado penal y la prisión-muerte. Buenos Aires, Argentina: Editorial Universidad, 2001.

NUCCI, Guilherme de Souza. Código penal comentado. 9. ed. São Paulo: Editora Revista dos Tribunais, 2009-a.

Tribunais, 2008.

Leis penais e processuais penais comentadas. 3. ed. São Paulo: Editora Revista dos 
. Individualização da pena. 3 ed. São Paulo: Editora Revista dos Tribunais, 2009-b.

OLMO, Rosa del. América Latina y su criminología. 4 ed. México: Siglo Ventiuno Editores, 1999.

OTTOBONI, Mário. Vamos matar o criminoso? Método APAC. São Paulo: Paulinas, 2001.

PARRY, John. Psicologia da comunicação humana. São Paulo: Editora Cultrix, 1967.

PASCHOAL, Janaína Conceição. Direito penal, parte geral. Barueri, SP: Manole, 2003.

PAUPÉRIO, Arthur Machado; et. al. Projeto e anteprojetos de código penitenciário. Rio de Janeiro: Universidade Federal do Rio de Janeiro, 1978.

PELLEGRINO, Hélio. Psicanálise da criminalidade brasileira. In: Democracia x violência: reflexões para a Constituinte. Rio de Janeiro: Paz e Terra, 1986, p. 96-110.

PERROT, Michelle. O inspetor Bentham. In: O Panóptico. Belo Horizonte: Autêntica, 2000, p. $110-150$.

PERVIN, Lawrence A. Personalidade: teoria, avaliação e pesquisa. São Paulo: EPU, 1978.

PIAGET, Jean. O juízo moral na criança. São Paulo: Summus, 1994

PIERANGELI, José Henrique. Códigos penais do Brasil: evolução histórica. 2 ed. São Paulo: Editora Revista dos Tribunais, 2001.

PIERSON, George Wilson. Tocqueville in America. Nova York, EUA: Johns Hopkins Paperbacks edition, 1996.

PIRES, Álvaro. Beccaria, l'utilitarisme et la rationalité pénale moderne. In: Historire des savoirs sur le crime et la peine. Ottawa, Canada: Les Presses de l'Université d'Ottawa, 1998, p. 83-143.

PITOMBO, Sérgio Marcos de Moraes. Conceito de mérito, no andamento dos regimes prisionais. In: Revista Brasileira de Ciências Criminais. Ano 7, n. 27, julho/setembro, 1999, p. 149-158.

. Direitos humanos e processo penal. In: Direitos Humanos: visões contemporâneas. Associação Juízes para a Democracia, São Paulo, 2001-a, p. 107-113 de 2011.

. Execução penal. Disponível em: <www.sergio.pitombo.nom.br>. Acesso em: 7 jun.

. Pronúncia e o in dúbio pro societate. In: Boletim do Instituto Manoel Pedro Pimentel, n. 17, jul-ago/2001-b, p. 06-11.

PLATÃO. As leis, ou da legislação e epinomis. São Paulo: EDIPRO, 1999.

PLAYFAIR, Giles; SINGTON, Derrick. Prisão não cura, corrompe. São Paulo: IBRASA, 1969.

POPPER, Karl. Em busca de um mundo melhor. Portugal, Lisboa: Editorial Fragmentos, 2006.

PRADO, Lídia Reis de Almeida. A lógica do razoável na interpretação jurídica. In: Revista da Associação Juízes para a democracia. Ano 1, n. 2, jul-dez, 1996, p. 122-151. 
Editora, 2003.

O juiz e a emoção: aspectos da lógica da decisão judicial. Campinas: Millennium

PRINS, Adolphe. La defensa social y las transformaciones del derecho penal. Buenos Aires, Argentina: Ediar, 2010.

RABATÉ, Jean Claude. 1900 em Salamanca. Salamanca, Espanha: Ediciones Universidad de Salamanca, 1997.

RAUTER, Cristina. Criminologia e subjetividade no Brasil. Rio de Janeiro: Revan, 2003.

RILEY, John W.; RILEY, Matilde W. A comunicação de massa e o sistema social. In:

Comunicação e indústria cultural: leituras de análise dos meios de comunicação na sociedade contemporânea e das manifestações de opinião pública, propaganda e cultura de massa nessa sociedade. São Paulo: Ed. Nacional, 1978, p. 118-161.

REALE Júnior, Miguel. Instituições de Direito Penal. Rio de Janeiro: Forense, 2006.

. Novos rumos do sistema criminal. Rio de Janeiro: Forense, 1983.

; et. al. Penas e medidas de segurança no novo código. Rio de Janeiro: Forense, 1985.

REALE, Miguel. A ética do juiz na cultura contemporânea. In: Revista Forense, vol. 325. Rio de Janeiro: Forense, jan/março, 1994. p. 63-69.

REICH, Wilhelm. Psicologia de massas do facismo. São Paulo: Martins Fontes, 2001.

RIOS, Francisco Giner de los. Advertencia del traductor. In: Las doutrinas fundamentales reinantes sobre el delito e la pena en sus interiores contradiciones. Madri, Espanha: Librería de Victoriano Suárez, 1876.

. Filosofia y sociologia. Buenos Aires, Argentina: Editorial Tor, [1904].

ROCHA, Fernando A. N. Galvão da. Direito penal: curso completo, parte geral. 2. ed. Belo Horizonte: Del Rey, 2007.

RÖDER, Carlos David Augusto. Las doutrinas fundamentales reinantes sobre el delito e la pena en sus interiores contradiciones. Madri, Espanha: Librería de Victoriano Suárez, 1876.

ROIG, Rodrigo Duque Estada. Direito e prática histórica da execução penal no Brasil. Rio de Janeiro: Revan, 2005.

ROMANO, Roberto. Educação e direitos humanos. In: Direitos Humanos: visões contemporâneas. Associação Juízes para a Democracia, São Paulo, 2001, p. 123-133.

ROTH, Mitchel. Prisons and prison systems: a global encyclopedia. Connecticut, EUA: Greenwood Press, 2006.

ROXIN, Claus. Introdução ao direito penal e ao direito processual penal. Belo Horizonte: Del Rey, 2007.

RUSSELL, Bertrand. Porque não sou cristão e outros ensaios sobre religião e assuntos correlatos. São Paulo: Livraria Exposição do Livro, 1972. . Princípios de reconstrução social. São Paulo: Companhia Editora Nacional, 1952. 
RUSCHE, Georg; KIRCHHEIMER, Otto. Punição e estrutura social. Rio de Janeiro: Editora Revan, 2004.

SÁ, Alvino Augusto de. Considerações e sugestões acerca do projeto de reforma do código penal e de uma possivel reforma da lei de execução penal. Boletim IBCCRIM. São Paulo, v.8, n.97, dez., 2000, p. 3-5.

. Criminologia clínica e execução penal. 2011. 559 fls. Tese (Livre-Docência,

Departamento de Direito Penal, Medicina Legal e Criminologia), Faculdade de Direito, Universidade de São Paulo, São Paulo.

. Criminologia clínica e psicologia criminal. 2. ed. São Paulo: Editora Revista dos Tribunais, 2007.

. ALVES, Jamil Chaim. Dos pareceres da comissão técnica de classificação na individualização executória da pena: uma visão interdisciplinar. Boletim IBCCRIM. São Paulo, ano 17, n. 203, ago., 2009, p. 7-9

. O caos penitenciário... Seria mesmo um caos? Boletim IBCCRIM. São Paulo, ano 17, n. 203, out., 2009, p. 15-16. EPU, 1987.

Reincidência criminal: sob o enfoque da psicologia clínica preventiva. São Paulo:

. Transdisciplinariedade e responsabilidade da academia na questão penitenciária. Revista do Conselho Nacional de Política Criminal e Penitenciária. Vol 1. n. 17. dez, 2004, p. $15-26$.

SALILLAS, Rafael. Doña Concepción Arenal em la ciencia penitenciaria: conferencia leida em el ateneo de Madrid. Madri, Espanha: Librería de Victoriano Suárez, 1894. 1896.

. El delincuente español: el lenguaje. Madri, Espanha: Librería de Victoriano Suárez,

SALLA, Fernando. As prisões em São Paulo: 1822-1940. São Paulo: FAPESP, 1999.

SALVADOR Neto, Alamiro Velludo. Finalidades da pena: conceito material de delito e sistema penal integral. São Paulo: Quatier Latin, 2009.

SANTOS, Boaventura de Souza. Por uma concepção multicultural de direitos humanos. In: Revista Crítica de Ciências Sociais. Coimbra, Portugal. n. 48. jun., 1997, p. 11-32.

SANTOS, Washington dos. Dicionário jurídico brasileiro. Belo Horizonte: Del Rey, 2001.

SANTOS, Paulo Fernando. Lei de execução penal: comentada e anotada jurisprudencialmente. São Paulo: Livraria e Editora Universitária de Direito, 1999.

SARLET, Ingo Wolfgang. As dimensões da dignidade da pessoa humana: construindo uma compreensão jurídico-constitucional necessária e possível. In: Revista Brasileira de Direito Constitucional - RBDC, n. 09, jan./jun, 2007, p. 361-388

. Dignidade da pessoa humana e direitos fundamentais na Constituição Federal de 1988. Porto Alegre: Livraria do Advogado, 2002.

SCOTT, George Riley. Storia della tortura. Milano, Itália: 2006. 
SELBACH, Jeferson Francisco. Pegadas urbanas: Novo Hamburgo como palco do flêneur. Cachoeira do Sur, RS: Ed. do Autor, 2006.

SEN, Amartya. A ideia de justiça. São Paulo: Companhia das Letras, 2011.

SHECAIRA, Sérgio Salomão. Criminologia. 2 ed. São Paulo: Editora Revista dos Tribunais, 2008 . . Estudos de Direito Penal. Vol. II. Rio de Janeiro: Forense, 2010.

. Mídia e crime. In: Estudos criminais em homenagem a Evandro Lins e Silva (criminalista do século). São Paulo: Editora Método, 2001, p. 352-367.

. Penas alternativas. In: Penas restritivas de direitos: críticas e comentários às penas alternativas: Lei 9.714, de 25.11.1998. São Paulo: Ed. Revista dos Tribunais, 1999.

. Prisões do futuro? Prisões no futuro? In: Conversações abolicionistas: uma crítica do sistema penal e da sociedade punitiva. São Paulo: IBCCrim, 1997, p. 171-175. 2008

. Sistema de garantias e o direito penal juvenil. São Paulo: Ed. Revista dos Tribunais,

. CORRÊA Júnior, Alceu. Teoria da pena: finalidades, direito positivo, jurisprudência e outros estudos de ciência criminal. São Paulo: Editora Revista dos Tribunais, 2002.

SILVA, Cyro Marcos da. Entre autos e mundos. Belo Horizonte: Del Rey, 2003.

SILVA, Evandro Lins e. De Beccaria a Filippo Gramatica. In: Sistema penal para o terceiro milênio: atos do colóquio Marc Ancel. 2 ed. Rio de Janeiro: Revan, 1991. $\overline{\text { mar. } 2001 .}$

Sentença de pronúncia. Boletim IBCCRIM. São Paulo, v.8, n.100, p. Encarte AIDP,

SILVA, Haroldo Caetano da. Ensaio sobre a pena de prisão. Curitiba: Juruá, 2009.

. Execução Penal: com as inovações da Lei $n^{\circ} 10.072$, de $1^{\circ}$ de dezembro de 2003. Porto Alegre: Magister, 2006.

SILVEIRA, Renato de Mello Jorge. Direito penal supra-individual: interesses difusos. São Paulo: Editora Revista dos Tribunais, 2003.

SOUZA, Osni. Da remição: a perda dos dias remidos por falta grave. In: Execução penal: visão do TACRIM-SP. São Paulo: Editora Oliveira Mendes, 1998, p. 145-156.

SOUZA, Percival de. Sindicato do crime. São Paulo: Ediouro, 2006.

SPADONI, Lila. Psicologia realmente aplicada ao direito. São Paulo: LTr, 2009.

STAUDE, John-Raphael. O desenvolvimento adulto de C. G. Jung. São Paulo: Cultrix, 1995.

SÜB, Frank. El trato actual del mandato de determinación. In: La insostenible situación del derecho penal. Granada, Espanha: Comares, 2000.

SZAFIR, Alexandra Lebelson. Descasos: uma advogada às voltas com o direito dos excluídos. São Paulo: Saraiva, 2010. 
SWANEPOEL G.; SAFFY J.; ZIETSMAN J. Criminology. Africa do Sul: Pearson Education, 2008.

TANGERINO, Davi de Paiva Costa. Culpabilidade. Rio de Janeiro: Elsevier, 2011.

THOMPSON, Augusto. Quem são os criminosos? o crime e o criminoso: entes políticos. Rio de Janeiro: Lumen Juris, 1998.

TRISTÃO, Adalto Dias. Sentença criminal. 4 ed. Minas Gerais: Ed. Del Rey, 1999.

TUCCI, Rogério Lauria. Direitos e garantias individuais no processo penal brasileiro. São Paulo: Saraiva, 1993.

VARVIN, Sverre. O trauma e suas consequências. In: Violência ou diálogo?: reflexões psicanalíticas sobre terror e terrorismo. São Paulo: Perspectiva, 2008, p. 199-208.

VILAS BOAS, Crisoston Terto. Para ler Michel Foucault. São Paulo: Imprensa Universitária - UFOP, 1993.

VILLENA, Miguel Ángel. Adiós a las cadenzas: una biografia recuerda a Victoria Kent, que fue directora general de Prisiones en la II República. 2007. Disponível em:

$<$ www.elpais.com>. Acesso em 06 set 2011.

VINCI, Leonardo da. Obras literárias, filosóficas e morais. São Paulo: HUCITEC, 1997.

VITO, Gennaro F. Criminology: theory, research, and policy. Massachusetts, EUA: Word Headquarters, 2006.

VIVANCOS, Alejandro Ayuso. Visión crítica de la reeducación penitenciaria em España. Valencia, Espanha: Nau Libres, 2003.

WALTERS, Glenn D. Foundaitions of criminal science. Nova York, EUA: Greenwood Publishing Group, 1992.

WARAT, Luís Alberto. A definição jurídica. Porto Alegre: Editora Atrium, 1977.

; Pepê, Albano Marcos Bastos. Filosofia do direito: uma introdução crítica. São Paulo: Moderna, 1996.

WATSON, Stephen. Malingerers, the 'weakminded' criminal and the 'moral imbecile': how the English prison medical officer became an expert in mental deficiency, 1880-1930. In: Legal medicine in history. Cambridge, EUA: University of Cambridge, 1994, p. 223-242.

WEIS, Carlos. E a vara de execuções criminais de São Paulo, como vai? In: Revista da Associação Juízes para a democracia. Ano 5, n. 24, abr-jun, 2001, p. 2-3

WINNICOTT, D. W. A família e o desenvolvimento individual. São Paulo: Martins Fontes, 2005-a . Privação e delinquencia. São Paulo: Martins Fontes, 2005-b.

WOLFF, Maria Palma. Antologia de vidas e histórias na prisão: emergência e injunção de controle social. Rio de Janeiro: Lumen Juris, 2005.

WOLIN, Sheldon S. Tocqueville between two words: the making of a political and theorical life. New Jersey, EUA: Princeton University Press, 2001. 
WOLTON, Dominique. Pensar a comunicação. Brasília: Editora Universidade de Brasília, 2004.

YEPES, Rodrigo Uprimny. Estado social de derecho y decisión judicial correcta: um intento de recaptulación de los grandes modelos de interpretación jurídica. In: Hermenéutica jurídica: homenaje al maestro Darío Echandía. Bogotá, Colômbia: Ediciones Rosaristas, 1997, p. 113-131.

ZAFFARONI, Eugênio Raúl. Em busca das penas perdidas: a perda de legitimidade do sistema penal. Rio de Janeiro: Revan, 1999.

; BATISTA, Nilo; et. al. Direito penal brasileiro: primeiro volume. 3. ed. Rio de Janeiro: Revan, 2006.

; PIERANGeLI, José Henrique. Manual de Direito Penal Brasileiro: Parte Geral. São Paulo: Revista dos Tribunais, 1997.

ŽIŽEK, Slavoj. Primeiro como tragédia, depois como farsa. São Paulo: Boitempo, 2011. 